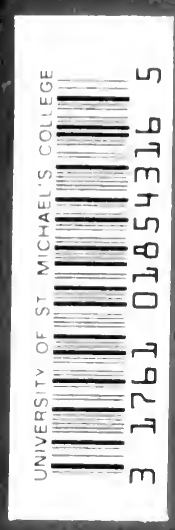

us is is 
\#2. 


$$
0
$$



ENGLISH DRAMA OF THE RESTORATION AND EIGHTEENTH CENTURY

(1642-1780) 


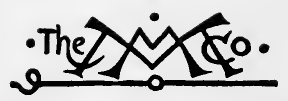

THE MACMILLAN COMPANY

NEW YORK - BOSTON - CHICAGO - DALLAS ATLANTA - SAN FRANCISCO

MACMILLAN AND CO., LIMITED

LONDON - BOMBAY - CALCUTTA - MADRAS MELBOURNE

THE MACMILLAN COMPANY

OF CANADA, LIMITED

TORONTO 


\title{
ENGLISH DRAMA OF THE RESTORATION AND EIGHTEENTH CENTURY (1642-1780)
}

\author{
BY \\ GEORGE HENRY NETTLETON \\ PROFESSOR OF ENGLISH IN YALE UNIVERSITY
}

New park

THE MACMILLAN COMPANY 
COPYRIGHT, 1914,

By THE MACMILLAN COMPANY.

All rights reserved - no part of this book may be reproduced in any form without permission in writing from the publisher, except by a reviewer who wishes to quote brief passages in connection with a review written for inclusion in magazine or newspaper.

Set up and electrotyped. Published March, 19r4.

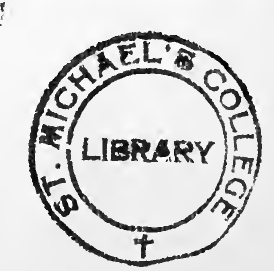

\section{FEB 71950}

SET UP AND ELECTROTYPED J. S. CUSHING CO. PRINTED IN THE UNITED STATES OF AMERICA BY BERWICK \& SMITH CO. 


\section{To}

SIR ADOLPHUS WILLIAM WARD

IN TOKEN OF FRIENDSHIP 



\section{PREFACE}

DESPITE the activity of research in the general field of English drama, and the marked growth of critical interest in its contemporary aspects, little heed has yet been given to certain earlier periods of modern English drama which help to explain its later development. For the most part, students of English dramatic history have preferred even the by-paths and meanders of Elizabethan drama to the maintravelled roads that lead onward from the eighteenth century. In one of the bibliographical notes in his admirable volume entitled Tragedy, Professor A. H. Thorndike puts the case tersely: 'Ward's History of Dramatic Literature ends with the death of Queen Anne; and there is no adequate history of the English drama for the last two centuries, and no good bibliography.' So vigorously, indeed, have almost all the fields of English literature been cultivated, that it is doubtful whether there now remains any other equally neglected area comparable in breadth with that clearly suggested by Professor Thorndike. His own concluding chapters, though confined to tragedy, form, in fact, one of the few significant contributions toward the broader critical investigation which must review the whole course of modern English dramatic development.

The present volume owes its origin to a plan, formulated some dozen years ago, to continue, though 
on a lesser scale, the history of English drama from the point where it was abandoned by Doctor - now Sir - Adolphus W. Ward. So intimate, however, are the relations between eighteenth-century drama and that of the Restoration, that it soon became advisable to include the earlier period, and ultimately to revert even to the dramatic interregnum which in reality links, while it seems to separate, Restoration and Elizabethan drama. In this way, it is hoped, the continuous development of modern English drama has been more clearly emphasized, and the necessary background for later critical discussion more definitely supplied. The present volume, accordingly, deals with the entire period from the closing of the theatres in 1642 to the culmination of eighteenthcentury drama in Sheridan. A subsequent volume, for which the material is largely in hand, will continue the record from about 1780 through the nineteenth century.

The aim of this work has been rather to ascertain the actual course of English drama than to warp its often discordant facts into conformity with a preconceived theory of dramatic evolution. Almost from the outset, in fact, it became necessary to discard many of the traditional assumptions of dramatic criticism. Even in the case of Restoration drama, which has received far greater critical attention than has hitherto been given to that of the eighteenth century, investigation has disclosed much that fails to harmonize with some of the articles prescribed by an earlier critical creed. Yet the tone of this work has not consciously been controversial. Throughout the main text and the Bibliographical Notes it has seemed 
preferable to emphasize the more trustworthy sources of information rather than to expose the shortcomings of unreliable works. Corrections of errors not infrequently detected even in many standard sources of reference have usually been made without comment. Even in the single detail of determining the dates of stage production of plays, full controversial evidence would have far exceeded the limits, as well as the purpose, of this volume. In the interest of accuracy, the Bibliographical Notes and footnotes supply definite information as to specific texts and editions cited, and the means of verifying statements of fact have been freely supplied even at the risk that the author may become an 'enginer hoist with his own petar.' It would be difficult to exaggerate the difficulties of accurate investigation, especially in those eighteenth-century theatrical records which reflect the careless gossip, anecdote, and reminiscences of the green-room. The effort to reduce the chances of error has included a checking at the British Museum and Bodleian Libraries of the entire proof, independent of the manuscript, and a similar rechecking of the page proof, so far as possible, at the Yale University Library. Yet I can hardly hope to have avoided all the pitfalls of the way, especially where it has often been overgrown with long neglect.

In a work which has spread over many years and over so broad a field, it is impossible to acknowledge fully the many debts constantly incurred. Yet by far my deepest obligation is to Sir Adolphus W. Ward. The extent to which all students of the drama are dependent on his History of English Dramatic Literature can best be realized by one who 
fares forth on the unfrequented seas of eighteenthcentury English drama, deprived of the friendly charts that have thus far safeguarded him. My personal debt, however, exceeds the common measure of obligation to Doctor Ward's scholarship. From his first generous endorsement of my general plan, his friendly counsel has been unfailing. During the past three or four years he has followed the entire work with stimulating and suggestive annotation of the manuscript, and with a constant and cordial encouragement which can here be acknowledged but imperfectly. It is a pleasant privilege, also, to recognize a deep and long-standing indebtedness to Professor Henry A. Beers of Yale. Many of the critical views here expressed were essentially derived from a graduate course under his direction, and doubtless these definite obligations are enlarged by many unconscious reminiscences of his thought or phrase. To other colleagues at Yale I am indebted in various ways in particular, to Professor Cross, for reviewing in proof the chapter on Fielding, and to Mr. Andrew Keogh, of the Yale University Library, for frequent and unwearying assistance. Much of this work would have been impossible without constant access to the British Museum and Bodleian Libraries, and its progress has been greatly furthered by the courteous aid of various officials at these places, and at the Cambridge University Library and the Bibliothèque Nationale.

This work is essentially based on original texts and documents. In the earlier drafts of the manuscript, quotations from plays or theatrical documents were regularly taken from the original texts, but 
since imperfections of typography and of scene division often involved correction or elaborate textual annotation, it seemed better eventually to modify a method of reference often inconvenient to the reader, and to utilize, to the extent indicated in the Bibliographical Notes, certain generally accessible modern critical editions and reprints. Dates of plays given in the main text are habitually those of their stage production, and have largely been determined through contemporary newspapers, magazines, playbills, and other definite records, such as authentic dated letters and diaries. These dates, it should be noted, often do not coincide with those of the first printed editions. Contemporary works of general character, such as memoirs, theatrical histories, and even autobiographies, have often proved very unreliable, but the best of them have supplied much valuable material. Though the present work is but incidentally concerned with questions of individual biography, the Dictionary of National Biography has proved of much assistance. Its statements have been largely verified, however, by independent investigation of early records, and some minor inaccuracies have thus been corrected. The Bibliographical Notes and the footnotes to the main text supply references to works consulted in the preparation of this volume, and indicate, at least to a considerable degree, those that have proved especially useful. Many of the works listed have contributed, at most, only indirectly to the present pages, but I wish to acknowledge as fully and as cordially as possible the investigations of previous writers. It would be idle to claim acquaintance with every work bearing on any part of the wide range of dramatic 
literature and theatrical history here discussed, but I have sought to acquaint myself as far as possible with the results of modern critical study as well as with the contemporary literature of the various periods.

There remains one matter in which a personal reference seems unavoidable. Some of the results of my investigation of eighteenth-century drama have already been formally presented. The Major Dramas of Richard Brinsley Sheridan, published in the Athencum Press Series in 1906, gives a much more detailed study of Sheridan and his relation to English drama than suits the proportions of the present work. It has seemed unnecessary to reproduce here the references and bibliographical data there accessible. For the tenth volume (1913) of The Cambridge History of English Literature, I prepared the fourth chapter, entitled 'The Drama and the Stage.' This section reviews the general aspects of Queen Anne drama and continues the critical account of eighteenth-century drama down to Goldsmith and Sheridan. Naturally, no essential modification of general viewpoints was possible, and a certain amount of duplication has been inevitable. That the work for the Cambridge History was undertaken at Doctor Ward's request, after he had in hand the manuscript of the present book, may account for my assumption of a dual rôle. Numerous differences in the selection and arrangement of the common material available for critical use, together with the marked distinction between the more extensive method of bibliography permitted in the Cambridge History and the more selective method in the present Bibliographical Notes, 
make these two works, it is hoped, supplementary rather than identical in character. Yet even if the history of eighteenth-century English drama has, in any sense, become a twice-told tale, I trust that the retelling of a much neglected story may find some listeners as generous as the kindly critic who has befriended both versions, and to whom I am privileged to inscribe this volume.

YaLe UnIVERsity,

1 November, 1913 



\section{CONTENTS}

CHATTER

PAGR

I. Contrasts between Elizabethan and ResTORATION DRAMA • . . . . . I

II. The Dramatic Interregnum, 1642-I660 • 14

III. The Beginnings of Restoration Drama and OPERA • • • • • • • • • 30

IV. Dryden, aNd the Heroic Drama . . . 53

V. ETherege aNd Wycherley (Shadwell) • 7 I

VI. Dryden, LeE, and Otway • • • . $\quad$. 88

VII. ASPECTS OF MINOR RESTORATION DRAMA . 104

VIII. Congreve, VANBrugh, and Farquhar • . I20

IX. The Moral Reawakening • . • . I4I

X. Some Aspects of Queen Anne Drama . . 166

XI. Pantomime and Ballad Opera • • . 183

XII. Voltaire's Influence and Bourgeois TragEDY • • • • • • • • • • 195

XIII. Fielding and the Licensing ACt . • . 213 XIV. THE Garrick ERA • • • • • 227

XV. The Lighter Drama of the Garrick ERA - 245 XVI. The Rise and Height of Sentimental

DRAMA • • • • • . . . $\quad 264$

JXVII. Goldsmith AND the Reaction in Comedy • 277 XVIII. Richard Brinsley Sheridan • • • . 291

BIBLIOGRAPHICAL NOTES • • • • • 315 INDEX • • • • • • • • • • 


\section{ENGLISH DRAMA OF THE RESTORA- TION AND EIGHTEENTH CENTURY}

\section{CHAPTER I}

CONTRASTS BETWEEN ELIZABETHAN AND RESTORATION DRAMA

Modern English drama may be said to begin with the Restoration of 1660 . The term 'modern' admits various definitions, but a convenient distinction may be made between the earlier period of English drama ending with the closing of the theatres, in $\mathrm{r}_{42}$, and the more modern period beginning, formally, with the creation of the Patent Theatres, under Charles II. / The history of a literature is, indeed, too continuous to permit rigid division into precise periods/ Even the interregnum when theatres were under Puritan ban does not, in reality, break a continuous dramatic tradition. The doors that closed against the earlier drama reopened to admit its reëntrance to the boards. Yet never has the course of English drama been interrupted so decisively as during the years when theatres were closed and drama underwent almost total eclipse. The ordinance of 2 September, 1642, which decreed that 'publike Stage-Playes shall cease, and bee forborne,' ${ }^{1}$ marked, rather than caused, the end of that great dramatic era which had risen to full height in Shakespeare and had already lapsed into literary and

' Facsimile reprint in Joseph Knight's edition, 1886, of Roscius Anglicanus; Journals of the House of Lords, V, 336 . 
moral decadence. The wave of creative power had well-nigh spent itself before reaching the barrier set up to arrest its progress. Originality had yielded largely to conventionality. There was dearth of poetry and excess of rhetoric. Comedy portrayed manners rather than the man. Tragedy sullied itself with gross passion and lust. Furthermore, the tragedy of blood on the mimic stage was destined to give way to the actual tragedy of civil war. Even before the formal suppression of the theatres, the Master of the Revels found his occupation gone, for his register closed with the significant entry: 'Here ended my allowance of plaies, for the war began in Aug. I642.' 1

The years between 1642 and 1660 formed a virtual, but not absolute, interregnum in the history of the drama and of the theatre. Closer examination of the actual conditions prevalent during the period will presently show that, despite severe threats of the law, the drama maintained a semblance of life. It had, however, no genuine vitality. With the creation of two companies of actors, under letters patent issued by Charles II, 2 I August, I660, and with the establishment of the two 'Patent Theatres,' the period of modern English drama may be said to have been inaugurated. It will be important hereafter to emphasize constantly the essential continuity of English dramatic development. It is, perhaps, equally important, at the outset, to review broadly, even at the risk of repeating familiar facts, some of

1 Sir Henry Herbert's 'Office-book,' cited in Malone's Shakspeare, I790 edition, Vol. I, Part II, p. 237. 
the salient differences between earlier English drama and that which begins with the Restoration.

Even in the mechanism of stage presentation, the Restoration theatre is distinct from its Elizabethan predecessor. 'Twere to consider too curiously, to consider here the disputed questions of Elizabethan scenery and of the sporadic appearances of actresses in England before the Restoration. It is enough to recognize that the general adoption of movable scenery and the regular employment of women as actors are noteworthy departures from the habitual usages of the Elizabethan stage. These and similar changes which affected primarily the theatrical manager or producer were not, to be sure, without direct influence upon the dramatist. The playwright is never independent of the conditions of actual stage production. Yet superficial differences between the Elizabethan and Restoration stages are less striking than fundamental differences in the drama they presented. How far the old order of drama changed in yielding place to new may be suggested by some general contrasts drawn between Elizabethan and Restoration drama.

It is a commonplace of criticism that the Elizabethan age is creative, the Restoration critical. In an uncreative age, criticism and satire become prominent. Dryden, the most commanding figure of Restoration drama, was less dramatist than critic and satirist. Broadly speaking, Elizabethan drama is spontaneous and original, Restoration drama artificial and imitative. Elizabethan comedy at its height is creative; Restoration comedy at its best is 
imitative of the fashions and follies of the beau monde. The one notably interprets character, the other chiefly reproduces characteristics. Between Falstaff and Sir Fopling Flutter is the difference between a masterly portrait and an admirable photograph. Again, the Elizabethans were impatient of artificial restraints. Shakespeare violated the dramatic unities ; Dryden advocated them, even if his practice did not always square with his precept. The Elizabethans were fond of blending tragedy with comedy; the Restoration playwrights usually inclined to separate them. The Elizabethans adapted freely materials from various sources, but their Restoration followers often borrowed manner as well as matter from Continental models. Restoration drama, in a word, lacks the spontaneity and originality of Elizabethan drama - imitates rather than creates - recognizes, even though it does not follow implicitly, conventional rules.

No less marked is the contrast between Elizabethan and Restoration drama in breadth of scope. The former is national, the latter local. Shakespeare sounds the whole gamut of life, but the comic dramatists of the Restoration repeat the notes of fashion, frivolity, and vice. Comedy in Dryden's age represents primarily only the life of the court. Hero and heroine know the world, but the world is London. The 'country' becomes a term of banishment with which to threaten wives not clever enough to hoodwink their husbands. Shakespeare portrays all the passions; Restoration comedy constantly reverts to the single passion of unlawful love. Tragedy, which flowed 
full and free in Elizabethan days, is channelled in 'heroic drama' between artificial banks difficult to surmount.

If Restoration drama lacks breadth of scope, it lacks also depth of feeling and height of poetic imagination. Even in rhymed and blank-verse tragedies there is dearth of poetic fancy. Comedy abandons poetry for prose. Romantic comedy yields to the comedy of manners. Common sense replaces poetic sensibility. Wit is more common than humour. The intellectual faculties are exalted above the emotional. It is an age which sees the founding of the Royal Society, and which has philosophers like Hobbes and Locke, and scientists like Newton, but poets are few. Rarely does even Restoration tragedy utter

those melodious bursts, that fill The spacious times of great Elizabeth With sounds that echo still.

The attitude toward Shakespeare is a valuable sidelight upon Dryden's period. Shakespeare was rewritten to suit an age which found Elizabethan genius rude and unrefined. Native wood-notes were too wild in days when Dryden deemed Shakespeare 'untaught, unpractised, in a barbarous age.' 1 Nahum Tate perverted King Lear with a happy ending. Dryden and D'Avenant with profane hands broke the charm of The Tempest. 'The Tragedy of Macbeth, alter'd by Sir William Davenant; being drest in all it's Finery, as new Cloath's, new Scenes, Machines, as flyings for the Witches; with all the Singing and Danc-

1 Prologue to Dryden's version of Troilus and Cressida. 
ing in it ... it being all Excellently perform'd, being in the nature of an Opera, it Recompenc'd double the Expence.' 1 Samuel Pepys, a confirmed and by no means unrepresentative playgoer, found Midsummer Night's Dream 'the most insipid ridiculous play that ever I saw in my life,' ${ }^{2}$ and Othello 'a mean thing' 3 in comparison with The Adventures of Five Hours. Beyond the Restoration horizon lay the forest of Arden and the seacoast of Bohemia.

But perhaps the most significant contrast between Elizabethan and Restoration drama is in moral tone. The immorality of Restoration comedy has become a byword, yet the subject is too vital to be dismissed lightly. Judged by modern standards, Elizabethan drama admitted at its best considerable vulgarity and indecency of speech, and in the period of its decline showed increasing tendencies toward grossness of thought as well as freedom of phrase. Distinction should, obviously, be made between frankness of expression and uncleanness of mind. The standard of permissible expression is, in a sense, matter of custom rather than of morality. Restraint of phrase counts less than purity of intention, for immorality may lie as much in what is to be read between the lines as in what actually appears on them. Yet, with every fair allowance, it must be admitted that Elizabethan drama is often not merely coarse but impure. Not even in its decadence, however, does it touch the depths of Restoration immorality.

1 Downes, Roscius Anglicanus, I 708, p. 33.

'Diary, 29 Sept., I662. Wheatley edition, II, 347.

Ibid., 20 Aug., 1666 . Wheatley edition, V, 407. 
Restoration comedy differs fundamentally from Elizabethan in deliberately enlisting the sympathy of the audience in favour of the wrong-doer. The earlier drama, with all its sins, inclines to award dramatic justice, however belated, to the virtuous. Restoration comedy, disdaining fifth-act compromise, often lets vice rampant in the earlier acts remain vice triumphant. The curtain falls with plaudits for the country wife who carries out a London intrigue without detection, and with derisive laughter for the husband who alone remains unconscious of his dishonour. Restoration comedy flaunts shamelessly the blazon of the 'scarlet letter.' It laughs not merely indulgently at vice, but harshly at the semblance of virtue. Cavalier contempt went so far as to regard the show of virtue as proof of hypocrisy. Cynicism replaced religion. Piety was considered bourgeois. Contempt for hypocrisy, however, did not extend to the hypocrisy of the intriguant. All was fair in amorous intrigue. The seducer who outwitted the deluded husband became not the villain but the hero. In the women deception was both a necessity and a virtue. Restoration comedy showed less the frailty of human nature than the strength of animal passion. So utterly subversive of moral standards is Restoration comedy that an attempt has been made to defend it on the ground that it dealt with an unreal world to which no ordinary standards are applicable. This brilliant fallacy is put forward by Charles Lamb in his essay On the Artificial Comedy of the Last Century. The characters of Restoration comedy seem to Lamb to have escaped from the actual world 
where moral law still reigns into 'the Utopia of gallantry, where pleasure is duty, and the manners perfect freedom. . . . We are not to judge them by our usages. No reverend institutions are insulted by their proceedings,- for they have none among them. No peace of families is violated,- for no family ties exist among them. No purity of the marriage bed is stained,- - for none is supposed to have a being. No deep affections are disquieted,- no holy wedlock bands are snapped asunder,- for affection's depth and wedded faith are not of the growth of that soil. There is neither right nor wrong, - gratitude or its opposite, - claim or duty, - paternity or sonship.' But Restoration comedy was 'artificial' only in so far as the court life which it mirrored was artificial. It portrayed all too faithfully the Vanity Fair of the Merry Monarch.

Macaulay, with the heavy hand of common sense, relentlessly crushed to earth Lamb's poetic fancy. His essay on the Comic Dramatists of the Restoration ${ }^{1}$ swept away specious pleas in defence of artificial comedy. 'The morality of the Country Wife and the Old Bachelor,' he writes, 'is the morality, not, as Mr. Charles Lamb maintains, of an unreal world, but of a world which is a great deal too real. . . . Here the garb, the manners, the topics of conversation are those of the real town and of the passing day. The hero is in all superficial accomplishments exactly the fine gentleman whom every youth in

1 Often entitled Leigh Hunt, of whose edition of The Dramatic Works of Wycherley, Congreve, Vanbrugh, and Farquhar Macaulay's essay was ostensibly a review. 
the pit would gladly resemble. The heroine is the fine lady whom every youth in the pit would gladly marry. The scene is laid in some place which is as well known to the audience as their own houses. . . . A hundred little touches are employed to make the fictitious world appear like the actual world. And the immorality is of a sort which never can be out of date, and which all the force of religion, law, and public opinion united can but imperfectly restrain.' Macaulay utterly scouts the idea that Restoration dramatists deal with an un-moral world. 'Morality constantly enters into that world, a sound morality, and an unsound morality; the sound morality to be insulted, derided, associated with everything mean and hateful; the unsound morality to be set off to every advantage, and inculcated by all methods, direct and indirect. It is not the fact that none of the inhabitants of this conventional world feel reverence for sacred institutions and family ties. Fondlewife, Pinchwife, every person in short of narrow understanding and disgusting manners, expresses that reverence strongly. The heroes and heroines, too, have a moral code of their own, an exceedingly bad one, but not, as Mr. Charles Lamb seems to think, a code existing only in the imagination of dramatists. It is, on the contrary, a code actually received and obeyed by great numbers of people. We need not go to Utopia or Fairyland to find them.' The final conclusion is driven home inexorably. 'The question is simply this, whether a man of genius who constantly and systematically endeavours to make. . . . [evil] character attractive, by uniting it with beauty, 
grace, dignity, spirit, a high social position, popularity, literature, wit, taste, knowledge of the world, brilliant success in every undertaking, does or does not make an ill use of his powers. We own that we are unable to understand how this question can be answered in any way but one.'

Macaulay's blunt dogmatism has sometimes irritated the artistic sympathies of sensitive critics. Some have been tempted to err with Lamb rather than take sides with Macaulay. Yet contemporary evidence is significant in this clash between sense and sensibility. It will suffice to mention two different but equally convincing documents. Hamilton's Memoirs of Count Grammont gives testimony of the court; the Diary of Samuel Pepys gives testimony of the city. The Diary is both too extensive and too familiar to permit minute comment. Pepys, himself not unaware of human frailty, was doubtless readier to extenuate than to set down aught in malice, yet his pages echo the gossip and scandal of the court of the Merry Monarch, the notes of changing fashions and unchanging folly and vice. Wide differences there are between the quaint entries in the Diary of Pepys and the gay, vivacious, graceful pages of Hamilton, but the differences are of style rather than of substance. In the Memoirs live again the King and his courtesans, the profligateDuke of Buckingham, and the Earl of Rochester, who boasted that he had been drunk for five years at a stretch. To Hamilton, Grammont is the beau ideal of the age. 'It is this indefinable brilliancy, which, in war, in love, in gaming, and in the various stages of a long life, has 
rendered the Count de Grammont the admiration of his age, and the delight of every country wherein he has displayed his engaging wit, dispensed his generosity and magnificence, or practised his inconstancy.' 1 Macaulay might have termed Grammont an unprincipled gambler, a dishonourable adventurer, and an abandoned profligate. Late in life the Chevalier looked back upon the past with Shallow's smack of satisfaction in 'the days that we have seen,' but without need of magnifying glasses. The adventures in the Memoirs are one with the incidents of the Restoration stage. Miss Price and Miss Jennings, in merry mood, diguise themselves as orange-girls, visit the theatre, and encounter Beau Sidney and Killigrew. Rochester, with the devilish ingenuity of Wycherley's Horner, practises intrigue in the disguise of 'a famous German doctor.' Lady Chesterfield, taken off by her husband to the country, consoles herself by writing her lover of her sufferings in 'the most horrible of prisons' in phrases which voice the familiar sentiments of Restoration heroines on the stage: 'Whatever the country affords most melancholy, in this season, presents itself to my view on all sides: surrounded by impassable roads, out of one window I see nothing but precipices; but wherever I turn my eyes within doors, I meet those of a jealous husband, still more insupportable than the sad objects that encompass me.' ${ }^{2}$ Incidents, adventures, and attitude are one with those of 'artificial comedy.' The world of Restoration comedy was not Utopia, but London.

1 Memoirs of Count Grammont, Goodwin edition, I, 3.

I Ibid., II, 3-4. 
The general contrasts drawn in the preceding pages between Elizabethan and Restoration drama have been so unfavourable to the later period that it may be asked what defence can be made for Restoration drama. Defence, it may at once be answered, is not the business of the historian. His task is rather to set forth the facts as he finds them, and to interpret them, to the best of his ability, not as a special pleader but as an impartial judge. Nor should it be necessary for him to try to heighten lesser peaks in the range of English drama by limiting his horizon to the immediate foreground. It would be possible, no doubt, since Gulliver becomes a giant in Lilliput, to magnify the achievements of Restoration drama by lowering the standard of judgment. Study of the beginning and growth of modern English drama does not, however, need questionable aids to give it value or enhance its interest. Despite its limitations and shortcomings, the drama of the past two centuries and a half has been linked too closely with the lives and interests of the English people to be dismissed as unworthy of serious notice. Whether comedy laughs with the sins of the Restoration, or weeps with the sentimentality of the eighteenth century, it bears the form and pressure of the age. Even when tragedy seems most aloof from human hearts, it won the plaudits of its passing day. 'The drama's laws the drama's patrons give' - at least, in large measure. Furthermore, in the period whose development is about to be traced, the comedy of manners comes to its fullest development. Tragedy learns to speak the accents of prose as well as the cadence of verse, and 
finds suffering and sorrow in bourgeois life. Stagecraft schools itself with experience, and acting touches noble heights. Opera and pantomime rise to do battle for popular favour with regular drama. Gain and loss, success and failure, play their parts in the varying record. And because the story of modern English drama, with its conflicts and struggles, is essentially human, it is itself a great drama of English national life. 


\section{CHAPTER II}

THE DRAMATIC INTERREGNUM, I642-I660

The period between the closing of the theatres, in I642, and the formal resumption of theatrical activity under royal patent, in 1660 , may conveniently be termed the dramatic interregnum. Throughout this period, especially toward its close, the drama maintained some semblance of life, but it had no genuine vitality. During the civil war most of the actors seem to have enlisted on the Royalist side, in natural loyalty to the party which had supported them against Puritan hostility. They had not forgotten that Prynne's attack upon them had been visited with fines, imprisonment, and even physical punishment. Under the commonwealth, however, the hand of the law was against them. An ordinance of 22 October, 1647, providing that actors in 'Stage Plays, Interludes, or other Common Plays' be 'punished as Rogues, according to Law,' 1 was followed by the drastic ordinance of II February, I648, which empowered the Lord Mayor and others to destroy galleries, seats, and boxes in the theatres, to flog actors, and to cause them to enter into recognizances 'never to Act or play any Plaies or Interludes any more,' and to fine spectators for the benefit of the

1 Journals of the House of Lords, IX, 490; W. C. Hazlitt, The English Drama and Stage, pp. 64-65. 
poor. ${ }^{1}$ The distractions of civil war and the severity of the law thus militated alike against the stage.

The cessation of dramatic and theatrical activity between 1642 and 1660 was, nevertheless, virtual rather than absolute. Even legal deterrents did not prove wholly effectual. 'When the Wars were over,' says Historia Histrionica: An Historical Account of the English-Stage (1699), 'and the Royalists totally Subdued; most of 'em [the actors] who were left alive gather'd to London, and for a Subsistence endeavour'd to revive their Old Trade, privately. They made up one Company out of all the Scatter'd Members of Several; and in the Winter before the King's Murder, 1648 , They ventured to Act some Plays, with as much caution and privacy as cou'd be, at the Cockpit.' After three or four days they were interrupted while presenting a tragedy and carried off to prison for a time. 'In Oliver's time, they used to Act privately, three or four Miles, or more, out of Town, now here, now there,' but such performances were rather surreptitious.

While more ambitious dramatic ventures thus ran the hazards of the law, the edicts against stage-plays seem not to have been applied rigorously to various minor theatrical pieces. The very title of The Actors Remonstrance, or Complaint: for the silencing of their profession, and banishment from their severall Play-houses (I643) calls attention to the players' 'grievances, for their restraint ; especially since Stageplayes, only of all publike recreations are prohibited;

${ }^{1}$ Hazlitt, op. cit., pp. 65-70; Journals of the House of Lords, X, $4 \mathrm{I}-42$. 
the exercise at the Beares Colledge [Bear-Garden], and the motions of Puppets being still in force and vigour.' The pamphlet itself protests that 'Puppitplays, which are not so much valuable as the very musique betweene each Act at ours, are still up with uncontrolled allowance, witnesse the famous motion of Bell and the Dragon, so frequently visited at Holbourne-bridge; these passed Christmas Holidayes.' To the same effect runs the testimony of Francis Kirkman as to the production of 'drolls' 1 : 'When the publique Theatres were shut up, and the Actors forbidden to present us with any of their Tragedies, because we had enough of that in earnest; and Comedies, because the Vices of the Age were too lively and smartly represented; then all that we could divert our selves with were these humours and pieces of Plays, which passing under the Name of a merry conceited Fellow, called Bottom the Weaver, Simpleton the Smith, John Swabber, or some such title, were only allowed us, and that but by stealth too, and under pretence of Rope-dancing, or the like; and these being all that was permitted us, great was the confluence of the Auditors.' Kirkman then pays tribute to 'the incomparable Robert Cox, who was not only the principal Actor, but also the Contriver and Author of most of these Farces,' and points out that 'these Compositions . . . were the fittest for the Actors to Represent, there being little Cost in Cloaths, which often were in great danger to be seized by the then Souldiers.'

The 'drolls' were short pieces, usually of a comic 1 Preface to The Wits: or, Sport upon Sport (1673). 
nature, and often culled from regular plays. As early as 1662 , the bookseller Francis Kirkman published a collection of them entitled, The Wits, or, Sport upon Sport. In Select Pieces of Drollery, Digested into Scenes by way of Dialogue. In the various editions of this popular work the different terms, 'drolls,' 'humours,' 'droll-humours,' 'drolleries,' and 'farces,' seem to be used with little or no distinction in meaning. The adoption of the single term 'droll' may, accordingly, avoid confusion. The drolls of the dramatic interregnum must not, however, be confused with the earlier puppet-shows sometimes designated by the same term, or with the non-dramatic versifications found in such a collection as the Westminster Drolleries of 1672 . With the revival of formal drama after the Restoration, the drolls attracted less favour, but the title of the 1673 edition of Kirkman's collection is a valuable indication of their previous scope and popularity: 'The Wits: or, Sport upon Sport. Being A Curious Collection of several Drols and Farces, Presented and Shewn For the Merriment and Delight of Wise Men, and the Ignorant: As they have been sundry times Acted In Publique, and Private, In London at Bartholomew In the Countrey at other Faires. In Halls and Taverns. On several Mountebancks Stages, At Charing-Cross, Lincolns-Inn-Fields, and other places. By Several Stroleing Players, Fools, and Fidlers, And the Mountebancks Zanies. With loud Laughter, and great Applause. Written I know not when, by several Persons, I know not who; But now newly Collected by your Old Friend to please you, Francis Kirkman.' 
Kirkman's tribute to Robert Cox as 'the Contriver and Author of most of these Farces' may prove somewhat misleading. Most of these farces can, in fact, be traced to Elizabethan sources. The 1672 and I673 editions of Kirkman's collection contain two very brief pieces based on the Old Testament, King Ahasuerus and Queen Esther, and King Solomon's Wisdom, but usually a marked preference is shown for excerpts from Elizabethan plays. It is preferable to select for more detailed examination the $\mathbf{1 6 6 2}$ edition of The Wits, or, Sport upon Sport, since its early date gives strong presumption that most of the pieces were used during the interregnum. This collection contains twenty-seven pieces, of which two drawn from Shakespearean plays may serve as convenient examples. The Grave-Makers takes the grave-diggers' scene from Hamlet, The Bouncing Knight [Falstaff] includes most of two Eastcheap tavern scenes and parts of the scenes that include Falstaff's description of his ragged company and his soliloquy on 'Honour,' and concludes with Falstaff's counterfeit death on the battle field, Prince Hal's eulogy, and Falstaff's resurrection. Striking testimony to the popularity of Beaumont and Fletcher is afforded by the fact that of the remaining pieces in this collection about half are apparently from plays in which they either collaborated or had an important hand. That performances of Beaumont and Fletcher's A King and No King ${ }^{1}$ and Fletcher's The Bloody

${ }^{1}$ J. P. Collier, History of English Dramatic Poetry, 1879 edition, II, 37, 40. Collier's contradiction in dates does not affect the main fact. 
Brother should have been forcibly interrupted, ${ }^{1}$ while lighter passages from their works appear to have escaped censure, seems hardly consistent with Macaulay's famous dictum that the Puritans objected to bear-baiting not because it gave pain to the bear but because it gave pleasure to the spectators. Yet Kirkman's Preface shows that various devices were adopted to cloak the real nature of some of these entertainments. Whatever the reasons were for their comparative immunity from attack, the drolls maintained effectively that comic spirit which needed only the formal reopening of the theatres to find free utterance. They bear significant testimony to the continuity of Elizabethan dramatic tradition even during the interregnum.

Further proof of the maintenance of some interest in the drama during the interregnum may be drawn from the continued publication of dramatic work. Various plays of Shirley, Quarles, D'Avenant, Baron, the Killigrews, Cokayne, Chamberlayne, and others, appeared in print. Even under the commonwealth, Cavalier resentment sometimes found a way to vent, in printed drama, feelings that were debarred utterance on the public stage. In 1648 were published the two parts of a play whose title-pages give sufficient indication of party feeling: 'Craftie Cromwell : or, Oliver ordering our New State. A TragiComedie. Wherein is discovered the Trayterous undertakings and proceedings of the said Nol, and his Levelling Crew. Written by Mercurius Melancholicus' and 'The Second part of Crafty Crumwell

${ }^{1}$ Historia Histrionica, 1699, pp. 8-9. 
or Oliver in his glory as King. A Trage Commedie Wherein is presented, the late treasonable undertakings, and proceedings, of the Rebells, their murthering of Capt. Burley, with their underhand workings to betray their KING. Written by Marcurius Pragmaticus.' It was a portent of that Cavalier spirit which, after the Revolution, could drop the mask of anonymity, and turn to rend its persecutors.

The evidence already presented is enough to prove that the dramatic interregnum interrupts, but does not wholly break, the continuous course of English drama. Yet publication of plays, sporadic attempts to perform regular plays, and even frequent productions of drolls imparted to the drama artificial stimulus rather than genuine vitality. As the period of the commonwealth drew toward its close, however, the languid pulse of drama was quickened by the stimulus of a more vital force. This more definite reawakening of dramatic activity was due primarily to Sir William D'Avenant (I606-I668). In D'Avenant's case, as in that of the drama itself, the interregnum arrested, but did not fully check, dramatic effort. D'Avenant himself may be regarded as the most conspicuous link between Elizabethan and Restoration drama. As the successor of Ben Jonson to the poet laureateship, he is, in a sense, heir to the Elizabethans. More literally, tradition has sought to link the story of his birth with the name of Shakespeare. Shakespearean blood can be traced, at all events, in the veins of D'Avenant's dramatic adaptations. His early plays, often resembling Beaumont and Fletcher's romantic dramas, antedate the closing 
of the theatres; The Siege of Rhodes (1656) and its immediate successors mark the reawakening of dramatic impulses during the interregnum; his later plays belong to the opening of the Restoration period, but are chiefly Shakespearean adaptations. Through him the Elizabethan birthright, however debased by the misuse of years, was transmitted to Restoration playwrights.

It was natural that D'Avenant, who had tasted dramatic success in the decade before the closing of the theatres, and who had been prevented by force of adverse circumstances from profiting by the patent empowering him, in 1639 , to erect a playhouse, should seek an early opportunity to resume his dramatic career. Under the commonwealth, his activities in behalf of the Royalists brought upon him imprisonment and even the fear of death. During the closing years of the commonwealth, however, the edicts against dramatic productions seem not to have been enforced with their former rigour. Yet D'Avenant was careful to disguise the real nature of his new theatrical projects. In seeking the support of Sir Bulstrode Whitelocke, the Lord Keeper, for his venture, he took pains to term his work 'our opera.' The title-page of the 1656 quarto of The Siege of Rhodes betrays equal caution in describing the piece as 'Made a Representation by the Art of Prospective in Scenes, And the Story sung in Recitative Musick.' Scenery and music thus became stalking-horses under the presentation of which D'Avenant shot his dramatic

1 Letter to Whitelocke, under date 3 September, 1656, Whitelocke's Memorials of the English Affairs, 1732 edition, p. 650. 
bolts. His first tentative theatrical essay was given at a private house, though the taking of admission fees gives to the performance a quasi-public character. This First Days Entertainment at Rutland-House, By Declamations and Musick: After the manner of the Ancients, was produced in 1656 , though it did not appear in print until the following year. It consists of two disputes, one between Diogenes and Aristophanes on the general question of public entertainments, the other between 'a Parisian and a Londoner in the Livery Robes of both Cities, who Declaim concerning the prae-eminence of Paris and London.' Each dispute concludes with a song and chorus, while the four long harangues are each preceded by appropriate music. The epilogue shows the underlying hope of reviving real plays in its final hint to the audience to 'get them if you can.'

But D'Avenant was not content with suggestion merely. Boldly developing the use of music and scenery, he produced in The Siege of Rhodes ( 1656 ) what has been regarded usually as the first English opera, and sometimes as the first English heroic play. The masque, with its music, scenery, and dancing, had already anticipated in private entertainments salient features which opera was now to develop on the regular stage. Elements of the heroic play had, likewise, already appeared in Elizabethan days. Through hero-plays like Marlowe's Tamburlaine, through the heroic romances of Beaumont and Fletcher, through such tragi-comedies as those of Massinger and Shirley, may be traced, at least roughly, a line of descent toward the heroic play. 
Long before the Continental impress was stamped upon Restoration tragedy, the English stage had become acquainted with many essential elements of heroic drama. - Love and honour ${ }^{1}$ had already fought their way through sensational entanglements to surprising dénouements. The horrors of the early tragedy of blood had been largely mitigated, and virtue and valour had often been crowned not with death, but with victory. Yet despite deep undercurrents which flow from early sources, the stream of English drama may, with The Siege of Rhodes, be said to take a new and noteworthy turning.

Whether or not this piece is to be regarded as a heroic play is largely a matter of arbitrary definition. Those who associate 'heroic drama' primarily with the use of the 'heroic couplet' usually set as its extent the years from 1664 to 1678 . This, certainly, is its period of fullest development and authority. Those who prefer to accentuate the elements suggested by the very term 'heroic' rather than the strict rhymed verse form are willing to admit wider limits. Without attempting to settle a controversy whose conclusion varies with the premises adopted, it may be convenient to accept the strict limits set for heroic drama proper, at the same time insisting upon its intimate relation with plays that fail to conform to the rigid definition. Dryden, the most conspicuous advocate and exemplar of the 'heroic couplet' in tragedy, did not fail to acknowledge that 'for Heroic Plays . . . the first light we had of them, on the

${ }^{1}$ This is the very title of one of D'Avenant's plays, acted I634, though not published until 1649 . 
English theatre, was from the late Sir William D'Avenant.' 1 In presenting, in a semi-historical atmosphere and in a foreign setting, themes of love and valour that concern characters of high rank moving before a background of war, The Siege of Rhodes resembles the heroic play in essence, but it substitutes freedom in verse forms for the restraint of the ' heroic couplet.'

D'Avenant himself, in his address 'To the Reader,' gives interesting comment upon both the heroic and poetic elements in his piece: 'The Story represented ... is Heroical, and not withstanding the continual hurry and busie agitations of a hot Siege, is (I hope) intelligibly convey'd to advance the Characters of Vertue in the shapes of Valor and conjugal Love. . . . You may inquire, being a Reader, why in an heroick Argument my numbers are so often diversify'd and fall into short fractions; considering that a continuation of the usual length of English verse would appear more Heroical in reading. But when you are an Auditor you will finde that in this, I rather deserve approbation then need excuse; for frequent alterations of measure ... are necessary to Recitative Musick for variation of Ayres.'

These latter phrases emphasize the fact that The Siege of Rhodes, however closely akin to heroic drama, was written not as a play but as an opera. With lines ranging from two to five accents and variously rhymed, it was intended partly for song and partly for recitative. In a passage that shows the novelty of recitative, and suggests its foreign origin, D'Avenant terms it 'unpractis'd here; though of great

\section{Essay of Heroic Plays, Ker, I, 149.}


reputation amongst other Nations.' 1 Again he suggests the limitations imposed by its use, in defending the poverty of plot 'because we could not convey it by more than seven Persons; being constrain'd to prevent the length of Recitative Musick, as well as to conserve, without incumbrance, the narrowness of the place.' Each of the five 'Entries' into which the opera is divided ends with a chorus. The lame and impotent conclusion of the final one will sufficiently show the variety of verse form, while the first four lines quoted might, with some justice, be applied to D'Avenant's own poetic efforts :

You began the Assault

With a very long Hault ;

And, as haulting ye came,

So ye went off as lame;

And have left our Alphonso to scoff ye.

To himself, as a Daintie,

He keeps his Ianthe;

Whilst we drink good Wine, and you drink but Coffy.

In the use of scenery, The Siege of Rhodes deliberately emphasized an element of theatrical art to which the public stage of the Elizabethans had been, in general, indifferent. Court masques had been lavishly set and costumed, and evidences are not wanting of occasional attempts to enrich the background of regular drama. Yet it would be unfair to deny the essential novelty of the conscious and continuous movement to elaborate scenic art which is so largely indebted for its impulse to D'Avenant. Even his 'Ornament which encompass'd the Scene'

${ }^{1}$ Address 'To the Reader' in 1656 quarto of the play. 
has suggestions of historical setting in showing 'the proper cognisance of the Order of the Rhodian Knights,' and 'on an Antique Shield the Crescent of the Ottomans.' 1 The stage direction before the 'First Entry' runs thus: 'The Curtain being drawn up, a lightsome Sky appear'd, discov'ring a Maritime Coast, full of craggy Rocks, and high Cliffs, with several Verdures naturally growing upon such Scituations; and, a far off, the true Prospect of the City RHoDes, when it was in prosperous estate: with so much view of the Gardens and Hills about it, as the narrowness of the Room could allow the Scene. In that part of the Horizon, terminated by the Sea, was represented the Turkish Fleet making towards a Promontory some few miles distant from the Town.' The description before the 'Fourth Entry' reads: 'The Scene is vary'd to the Prospect of Mount Philermus: Artificers appearing at work about that Castle which was there, with wonderful expedition, erected by Solyman. His great Army is discover'd in the Plain below, drawn up in Battalia; as if it were prepar'd for a general Assault.' D'Avenant probably produced these effects on small painted scenes or screens, for his limitations of space and cost are plainly emphasized. His Address to the Reader says, 'It has been often wisht that our Scenes (we having oblig'd our selves to the variety of Five changes) according to the Ancient Drammatick distinctions made for time) had not been confin'd to eleven foot in height, and about fifteen in depth, including the places of passage reserv'd for the Musick. This is

${ }^{1}$ These and the following quotations are from the 1656 quarto. 
so narrow an allowance for the Fleet of Solyman the Magnificent, his Army, the Island of Rhodes, and the varieties attending the Siege of the City; that I fear you will think, we invite you to such a contracted Trifle as that of the Caesars carv'd upon a Nut.' The Prologue to the Second Part, in the later enlargement of the piece, ${ }^{1}$ exclaims that if to the poet were given half the money

Which Faction gets from Fools to nourish Warr;

Then his contracted Scenes should wider be,

And move by greater Engines, till you see

(Whilst you Securely sit) fierce Armies meet, And raging Seas disperse a fighting Fleet.

In The Cruelty of the Spaniards in Peru (1658) and The History of Sir Francis Drake (1659), D'Avenant continued to mask dramatic matter under the garb of music and scenery. Both pieces are described in the first quartos as 'Exprest by Instrumentall and Vocall Musick, and by Art of Perspective in Scenes, \&c,' and the Peruvian setting in each allowed one 'Frontispiece' or 'Ornament' to do double duty.' Both operas, too, may have owed their immunity from Puritan persecution partly to the dominant English spirit of hostility to the Spaniards. Their real interest lies in the continuance of the musical elements of The Siege of Rhodes, in their kinship with heroic drama in the choice of semi-historical material and foreign setting, in the introduction of

1 The Siege of Rhodes, enlarged into two parts, was acted at Lincoln's Inn Fields in 1661 , and printed in 1663.

2 See 'The Discription of the Frontispiece' in the 1659 quarto of The History of $S^{r}$ Francis Drake. 
dancing, and in the evidences of some attempts at appropriate scenery and costumes. The 'First Entry' in The Cruelty of the Spaniards is prefaced thus: 'The Audience are entertain'd by Instrumentall Musick and a Symphany (being a wild Ayre sutable to the Region) which having prepar'd the Scene, a Lantdchap of the West-Indies is discern'd; distinguisht from other Regions by the parcht and bare Tops of distant Hills, by Sands shining on the shores of Rivers, and the Natives, in feather'd Habits and Bonnets, carrying, in Indian Baskets, Ingots of Gold and Wedges of Silver. Some of the Natives being likewise discern'd in their natural sports of Hunting and Fishing. This prospect is made through a wood, differing from those of European Climats by representing of Coco-Trees, Pines and Palmitos; and on the boughs of other Trees are seen Munkies, Apes and Parrots; and at farther distance Vallies of Sugar-Canes.' The Chief Priest of Peru is described as 'cloth'd in a Garment of Feathers longer then any of those that are worne by other Natives, with a Bonnet whose ornament of Plumes does likewise give him a distinction from the rest, and carryes in his hand a guilded Verge. He likewise, because the Peruvians were worshipers of the Sun, carryes the Figure of the Sun on his Bonnet and Breast.' The 'feather'd habits' of the Indians, the bows, glaives, spears, and quivers of the Peruvians, the cloaks, ruffs, rapiers, and daggers of the Spaniards, and the red coats of the English are carefully indicated in various stage directions.

In thus deliberately attempting not merely a more 
elaborate pictorial background, but a more faithful and consistent historical setting for drama, D'Avenant set in play forces whose ultimate results he could not have foreseen. Yet even the Restoration stage, in the brief years before his death, witnessed such development of scenery, costume, and stagecraft that the faint-hearted were fearful that the noble proportions of drama itself were being obscured under too sumptuous a mantle. D'Avenant's later work belongs to the opening years of Restoration drama. But his real significance in dramatic history lies in his reawakening of dramatic impulse in the closing years of the interregnum. He is at once both follower and leader - a link between Elizabethan and Restoration drama and a forerunner of modern English drama. 


\section{CHAPTER III}

\section{THE BEGINNINGS OF RESTORATION DRAMA AND OPERA}

THE formal opening of the period of modern English drama may be dated from the issuing by Charles II, on 2I August, I660, of letters patent conferring upon Thomas Killigrew and Sir William D'Avenant the right to 'erect' two companies of players. The advent of Charles II to the throne meant the restoration of drama, as well as of monarchy. The grant of 2 I August was of large significance. It restored to English drama, with the seal of royal authority, rights and privileges of which it has never subsequently been deprived. Yet the act that thus conferred larger liberty upon the drama marks, in fact, the creation of a theatrical monopoly from whose shackles the London stage was not wholly freed for almost three centuries. For the moment, however, it was enough that the ban on English drama was formally lifted.

The way, indeed, had already been opened for the resumption of theatrical activity. D'Avenant's productions at Rutland House had been followed by the performances of his operas, in 1658 and 1659 , on the public stage at the Cockpit Theatre, in Drury Lane. In early February, I660, General Monck entered London, and soon afterward a license for 
acting was given to John Rhodes, a London bookseller, said to have been previously connected with the Blackfriars Theatre as wardrobe-keeper. Before the issue of the patent of 2I August, three companies of actors had begun to be assembled - at the Cockpit, at the Red Bull, and at Salisbury Court, in Whitefriars.

The royal grant to Killigrew and D'Avenant, accordingly, aroused some dissensions. Sir Henry Herbert, standing on his dignity as Master of the Revels, protested to the King against this 'unjust surprize' which disregarded his authority, and sought to discredit D'Avenant by describing him as one 'who obtained leave of Oliver and Richard Cromwell to vent his operas, at a time when your petitioner owned not their authority.' Even after the failure of his petition, Herbert strove to block D'Avenant's path by the assumption of rights of censorship. His warrant demanding that plays to be acted at the Cockpit be submitted to him that 'they may be reformed of prophanes and ribaldry' fomented the dispute, but eventually the struggle ended with the practical victory of the patentees. Meanwhile, under definite agreement between the two patentees, the actors were divided into two companies. D'Avenant's company - known as the Duke of York's - settled, in 166r, at the new theatre in Lincoln's Inn Fields, removing finally to Salisbury Court, Fleet Street. Killigrew's company - known as the King's - was definitely established, in 1663 , at the Theatre Royal, later known as Drury Lane.

D'Avenant's dramatic work after the reopening 
of the theatres is far less significant than that which he inaugurated during the interregnum. Yet his revivals of several of his own pre-Restoration plays and his various adaptations from Elizabethan dramatists are definite links between Restoration and earlier English drama. The Siege of Rhodes was now expanded into two parts, and two plays that had been produced by D'Avenant in the days of Charles I were successfully revived. These were Love and Honour, which may be regarded as one of the transitional plays between the heroic romances of Beaumont and Fletcher and the 'heroic drama' of the Restoration, and The Unfortunate Lovers, a tragedy pronounced by Pepys, who witnessed it the day after its author's death, 'no extraordinary play.' 1 D'Avenant's new productions after the Restoration are chiefly adaptations from Elizabethan drama. Thus, The Law against Lovers (1662) blends with the darker tones of Measure for Measure the lively accents of Benedick and Beatrice; The Rivals (1664) alters The Two Noble Kinsmen; Macbeth (1664?) and The Tempest (1667) recast Shakespeare. Dryden, who assisted in the alteration of The Tempest, ascribed to D'Avenant the doubtful credit for the introduction, as a counterpart to Miranda, of 'a man who has never seen a woman.' The Playhouse to be Let (circ. I663) ${ }^{2}$ is a sort of potpourri, including such diverse elements as two of D'Avenant's interregnum operas, a burlesque on the story of Antony and Cleopatra, and a rendering of Molière in broken English. The Man's the Master

${ }^{1}$ Diary, 8 April, I668. Wheatley edition, VII, 397.

${ }^{2}$ Printed in the 1673 folio of D'Avenant's Works. 
(1668), a comedy with borrowings from Scarron, was revived as late as $I 775$.

D'Avenant's importance in English dramatic history is to be measured not by his own actual dramatic product but by the far-reaching and powerful forces which he set in motion. Crude and ineffective seem to the modern reader his dramatic efforts, yet to them must be accorded a prominence denied to many works of greater literary worth. The Siege of Rhodes is a distinct innovation whose historical significance is out of all proportion with its intrinsic merits. It remains one of the most notable landmarks in the course of English drama. In reviving theatrical performances, in regularly employing actresses and movable scenery, in heralding the 'heroic drama,' and in introducing opera, D'Avenant not merely set the fashion for early Restoration playwrights, but stirred impulses that have powerfully affected the whole course of modern English dramatic development. Yet his merits as a leader are enforced by his services as a follower of the Elizabethans. Through the dark years of the interregnum he kept alive some memory of a great national dramatic tradition. The fire of the Elizabethans had well-nigh burned itself out, but D'Avenant did not suffer its last sparks to become extinct.

Like D'Avenant, Thomas Killigrew ( 16 i $2-1683$ ) is a link between Elizabethan and Restoration drama. Some of his plays, among them several tragi-comedies in which the romantic vein of Fletcher is debased by extravagant conception and surcharged sentiment, appeared on the public stage before the 
Civil War. During the interregnum, in the course of a protracted foreign sojourn, he continued to write plays. After the reopening of the theatres, he revived some of his pre-Restoration dramas. Pepys witnessed Claracilla on 4 July, r66r, and on I I October, I664, recorded the suggestive comment of Luellin on the revival of Killigrew's early comedy, The Parson's Wedding: 'What a bawdy loose play this "Parson's Wedding" is, that is acted by nothing but women at the King's house.' The Restoration stage had become so quickly habituated to the appearance of actresses that it had discovered a novel way to whet the appetites of playgoers. It is as a 'merry droll' - to borrow a phrase from Pepys that Thomas Killigrew seems to have impressed the Merry Monarch and his followers. 'Tom Killigrew hath a fee out of the Wardrobe for cap and bells under the title of the King's Foole or Jester,' - so writes Pepys, I3 February, r668, - 'and may with privilege revile or jeere anybody, the greatest person, without offence, by the privilege of his place.' His serious dramatic efforts seem, for the most part, laboured, and most of the pieces collected in the $166_{4}$ folio of his works may be dismissed as 'closet-dramas,' but in some of his comic passages, whetted with the zest of indecency, there are suggestions of the 'many merry stories' which established his reputation as a wit.

In turning from an account of the dramatic work of D'Avenant and Killigrew to a broader survey of the Restoration drama under the leadership of the two patentees, it is well to emphasize one fact of vital importance. The roots of Restoration drama 
lie in Elizabethan soil. Yet the foreign graftings upon English stock have often attracted more attention than the native growth. Dryden and his followers based their theories largely on Gallic rules and conventions and their practice on Continental models, but it is wholly misleading to regard Restoration drama as an essentially foreign product. Comedy felt the influence of Jonson as well as of Molière, and tragedy pointed backward to Beaumont and Fletcher as well as to Corneille and Racine. Dryden could preach classical doctrines of the drama and admire Shakespeare. Theory might seek to separate tragedy from comedy, but the tragi-comedies of Beaumont and Fletcher still held the stage. The 'heroic drama' borrowed consciously from foreign sources, yet inherited no less surely an English birthright. Not seldom the hand is the hand of France, but the voice is the voice of England. The drama of Dryden's period is not the projection across the Channel of the straight line of Gallic convention; it is the resultant of English and Continental forces.

The reopening of the theatres brought the revival of numerous Elizabethan plays. John Downes, prompter at Lincoln's Inn Fields Theatre during practically the entire Restoration period, gives ${ }^{1}$ a list of fifteen 'Principal Old Stock Plays' acted during the earlier years of the Theatre Royal, later known as the Drury Lane. Two plays are by Dryden, three by Shakespeare, three by Jonson, seven by Beaumont and Fletcher. A supplementary list of old plays which 'were Acted but now and then; yet being well Per-

1 Roscius Anglicanus, 1708, pp. 3-8. 
form'd, were very Satisfactory to the Town' consists largely of works by Shakespeare, Jonson, Beaumont and Fletcher, and Shirley. Adaptations of still other Shakespearean plays gave them at least counterfeit presentment on the stage. Though his romantic comedies were denied the favour shown to The MerryWives of Windsor, Shakespeare's tragedies were reanimated by the genius of Betterton. Blurred and imperfect as was the Restoration vision, it was never blind to Elizabethan achievement. The interregnum had weakened, but not broken, the continuous chain of English drama.

With the Restoration, the pent-up forces of Cavalier sentiment that had found but narrow outlets under the commonwealth burst the barriers. The anonymous attacks upon Cromwell in such printed dramas of the interregnum as those previously described now gave way to open animosity. Early in I660, JoHN TAтHAM (fl. I632-I664), whose early dramatic efforts before the closing of the theatres had been followed by productions of city pageants during the closing years of the interregnum, produced 'at the Private House in Dorset-Court,' ${ }^{1}$ The Rump, or the Mirrour of the Late Times. Some of the characters are thinly disguised by the transparent trick of inverting their names - Bertlam for Lambert, Woodfleet for Fleetwood - but others are introduced without semblance of pretence. The abusive satire does not respect sex, for Lambert's wife and Cromwell's widow are alike victims. The bitter Cavalier feeling of The Rump found expression in various

${ }^{1}$ See title-page of 1660 edition. 
dramatic pieces not produced on the stage. Of these it is enough to cite two early examples. Cromwell's Conspiracy (printed I660) represents Cromwell in guilty intrigue with Mrs. Lambert, and in Hells Higher Court of Justice (printed r66r) the 'damned plagues' devised for his punishment seem adequate even for one said to deserve 'all, Nay more then ever hell yet knew.'

The virulence of Cavalier feeling was tempered to milder satire upon the Puritans by ABRAHAM Cowley (1618-1667) in Cutter of Coleman-Street (166I). This piece was a revision of The Guardian, which had been acted at Cambridge in $164 \mathrm{I}$, printed in 1650 , and, according to its author, ${ }^{1}$ privately presented several times during the interregnum. It is a commentary on the times that Cutter of ColemanStreet aroused resentment on account of its supposed strictures on the King's party. Royalist sentiment did not relish the frank portrayal of a drunken Cavalier in the person of Colonel Jolly, and Cowley deemed it necessary in an indignant preface to his first edition (1663) to answer charges of disloyalty because Cutter, 'a merry sharking fellow about the Town,' was represented as 'pretending to have been a Colonel in the Kings Army.' Yet Cutter mocks Puritan speech, garb, and the habit of referring everything to visions, and ends by marrying Puritan Tabitha and making her drunk and lewd. Apart from its political interest, Cowley's comedy has some effective strokes of characterization, and Lamb found it 'the link between the Comedy of Fletcher and of Congreve.' ${ }^{2}$

1 Preface to first edition of Cutter of Coleman-Street, 1663.

2 Specimens of English Dramatic Poets, in Lamb's Works, Lucas edition, IV, 432, footnote. 
Though the opening years of the Restoration theatres seem largely devoted to the revival of earlier dramas and to the novelty of political dramatic satire, there were early indications of more significant dramatic progress. In the work of JoHN WILSON (I627?-I696), Recorder of Londonderry, Restoration comedy is at once quickened by Elizabethan impulse and shown to be capable of genuine comic achievement. The comedies of Ben Jonson were speedily installed as favourites on the Restoration stage. Pepys saw The Silent Woman, 7 January, I66r, and Downes mentions it, together with Volpone and The Alchemist, as among the principal old stock plays at the Theatre Royal. John Wilson, though too vigorous to be dismissed merely as an imitator, fell naturally under Jonson's influence. In the Preface to The Cheats (written I662) ${ }^{1}$ he says: 'Comedy, either is, or should be, the true Picture of Vertue, or Vice; yet so drawn, as to shew a man how to follow the one, and avoid the other.' The Cheats is preëminently a 'humour comedy,' with deception, in its various forms, as the vice depicted. Bilboe and Titere $\mathrm{Tu}$ usurp the titles of Major and Captain, though they are but common bullies; Runter is a pretended legal authority; Scruple is a hypocrite - a Nonconformist who conforms for a living of $£_{300}$, but goes back to his flock for $£_{400}$ by 'natural affection'; Mopus is a quack astrologer. The strength of the comedy lies rather in characters and in dialogue than in plot. In The Projectors (printed 1665) the influence of Jonson shows in characters like Sir Gudgeon Credu-

${ }^{1}$ See title-page of first edition, printed 1664 . 
lous, the miser, Suckdry, the usurer, and Leanchops, the servant. The very names of the characters reveal the habit which Jonson popularized in 'humour comedy.'

The generous treatment usually accorded to Wilson's dramatic work by modern critics has tended perhaps to magnify his real position with his contemporaries. The Cheats was reprinted in each of the remaining decades of the century and had occasional performances as late as 1727 , yet theatrical chroniclers of the day, like Downes, are apt to give it little or no mention. In a letter of 28 March, I663, Abraham Hill says: 'The new play, called The Cheats, has been attempted on the stage; but it is so scandalous, that it is forbidden.' 1 Genest is so sceptical of the actual production of The Projectors that he includes it with Wilson's vigorous blank-verse tragedy, Andronicus Comnenius (printed I664), in his long list of 'Plays not acted.' Belphegor, or The Marriage of the Devil, described in the edition of $169 \mathrm{I}$ as 'lately acted at the Queen's Theatre in Dorset-Garden,' had a tardy posthumous hearing. Even the Biographia Dramatica dismisses Wilson briefly as 'the author of four plays.' No reader who has found relief from the dull monotony of so many lesser contemporary playwrights in Wilson's best passages will seek to disparage his dramatic merits. Yet the weight of evidence seems to point toward less decisive assertion of his immediate dramatic prominence and of his influence upon his contemporaries. None the less he remains an early Restoration follower of 'the tribe of Ben,' and

1 Familiar Letters of Abraham Hill, 1767, p. 103. 
a proof that the revived 'humour comedy' could create as well as imitate.

While frequent revivals, adaptations, and imitations of Elizabethan drama were thus exerting potent influence upon the early dramatic productions after the reopening of the theatres, the rapid development of scenic and other theatrical novelties tended more and more to differentiate the Restoration stage from the Elizabethan. Not in the written drama, but in the conditions of its presentation, are to be found the most striking early evidences of a new era in the development of the theatre. The influence of the theatrical innovations upon the drama itself was speedily recognized. Hardly had the Patent Theatres been well established when Richard Flecknoe, in $A$ Short Discourse of the English Stage, ${ }^{1}$ uttered a warning against the danger of allowing stage setting to distract attention from the drama proper. 'Now, for the difference betwixt our Theaters and those of former times, they were but plain and simple, with no other Scenes, nor Decorations of the Stage, but onely old Tapestry, and the Stage strew'd with Rushes, (with their Habits accordingly) whereas ours now for cost and ornament are arriv'd to the heighth of Magnificence; but that which makes our Stage the better, makes our Playes the worse perhaps, they striving now to make them more for sight, then hearing; whence that solid joy of the interior is lost, and that benefit which men formerly receiv'd from Playes, from which they seldom or never went away, but far better and wiser then they came.' Furthermore, in the prac-

${ }^{1}$ Attached to Love's Kingdom. A Pastoral Trage-Comedy, r664. 
tice that became well established during the next decade of transforming tragedy into opera, the change was effected in large part not merely by the use of music, but by the prominent introduction of scenery and stage devices. Of this, Downes gives abundant contemporary evidence. D'Avenant's alteration of Macbeth was 'drest in all it's Finery, as new Cloath's, new Scenes, Machines, as flyings for the Witches'; ${ }^{1}$ The Tempest 'was made into an opera ... having all New in it; as Scenes, Machines; particularly, one Scene Painted with Myriads of Ariel Spirits; and another flying away, with a Table Furnisht out with Fruits, Sweet meats, and all sorts of Viands'; ${ }^{2}$ 'In February 1673 . The long expected Opera of Psyche, came forth in all her Ornaments; new Scenes, new Machines, new Cloaths, new French Dances: This Opera was Splendi[d]ly set out, especially in Scenes; the Charge of which amounted to above $800 \mathrm{l}^{\prime}{ }^{3}$ The very success of these devices in opera reacted upon the regular drama, so that tragedy shows a new and increasing reliance upon spectacular effects.

Detailed account of various changes in scenery, costume, and stage machinery belongs rather to theatrical than to dramatic history. Yet it is important to recognize that the acted drama is never independent of the conditions attending its production. Even the crude settings of D'Avenant's operas show that efforts to visualize the drama's scenes cannot fail

1 Roscius Anglicanus, p. 33.

2 Ibid., p. 34.

Ibid., p. 35 . 
to raise questions, however imperfectly they may be answered, as to appropriateness of scene and costume. The introduction of movable scenery is, furthermore, not without direct influence on the Restoration limitation of scenes as compared with the free practice of the Elizabethan stage. Nor is it merely the sceneshifter with whom the playwright must now reckon. When the dramatist is no longer left alone to paint the moonlit avenue at Belmont or the fairy wood outside Athens, poetry of words may clash with prose of paint. Even Puff discovered that a clock striking four in the morning 'saves a description of the rising sun and a great deal about gilding the eastern hemisphere.' There need be no attempt to seek in the increasing attention to scenic art a vain excuse for the dull fancies of many Restoration playwrights, yet it should not be forgotten that the very poverty of Elizabethan setting doubtless stimulated the wealth of Shakespearean descriptions. The habitual employment of actresses on the Restoration stage may, likewise, be held to have influenced a drama which bent its energy largely to a licentious comedy of intrigue, and which speedily found ways to whet interest by the presentation of plays given wholly by actresses and by capping tragedy with epilogues whose coarseness was accentuated in a woman's mouth. In so far, then, as these radical innovations of the Restoration stage changed the environment of the playwright, they directly influenced his dramatic product.

In reviewing the early activities of the Restoration theatre, it has seemed advisable to defer until a separate 
chapter discussion of the dramatic work and influence of the most prominent Restoration dramatist. Yet, both to summarize the account already presented and to enlarge the scope of subsequent discussion, it is desirable to resolve, if possible, the component forces which have their resultant in Dryden's dramatic work. The dominant influence on English drama during the interregnum and the opening years of the Restoration period was, as has been seen, English. The Elizabethan tradition was continued through D'Avenant's essentially heroic themes to the 'heroic drama' of Dryden and Orrery, and through 'droll humours,' culled chiefly from Elizabethan plays, to Jonsonian 'humour comedies' like those of Wilson. It was likewise enforced by the Restoration adaptations of Shakespeare and the stage revivals of Elizabethan plays.

As the decade advanced, nevertheless, alien influences asserted themselves with increasing power. In The Siege of Rhodes D'Avenant had already introduced English opera, using recitative music which he declared to be 'unpractis'd here; though of great reputation amongst other Nations.' His words raise at once the question of foreign influence upon English opera. Too much stress should not be laid on D'Avenant's chance phrase. The facile assumption that early English opera is the product of French influences is dangerous. Under the protection of Mazarin, Italian opera had been carried into France as early as 1645. The real development of French opera, however, dates only from the decade of the seventies, a period subsequent to the operas of 
D'Avenant and other English writers. As operatic tendencies became accentuated in France, dramatists like Corneille, Molière, and Quinault had more or less to do with its libretti. All three, in fact, contributed to Psyché (167I), whose success turned Quinault to writing for Lulli, its composer, libretti which thoroughly established the popularity of French opera. The first French opera has been recently declared $^{1}$ to be the Pomone ( $167 \mathrm{I}$ ) of Cambert and Pierre Perrin, and the popular collaborations of Lulli and Quinault begin only in the very year, 1673 , when Shadwell turned The Tempest into an opera. Unquestionably the popularity of opera in France, and its occasional actual transfer to the English stage, stimulated operatic activity in England, especially in the decade which produced Matthew Locke's music to Psyche and the earliest of Purcell's operas, Didoand Aeneas (1680). Yet a score or so of years had already elapsed since the production of The Siege of Rhodes. Without attempting to disprove wholly the foreign influence upon early English opera which D'Avenant's own words imply, it would seem that the case should not rest here. Two reasons naturally suggest themselves to account largely for D'Avenant's introduction of English opera - his previous practice in the masque and his desire to cloak, under a novel disguise, the real nature of his dramatic efforts. His early operas are not an alien Continental product. In a word, French influence was more potent in the later development of Restoration opera than at its outset. Of Continental influences upon Restoration drama

${ }^{1}$ C. H. C. Wright, $A$ History of French Literature, 1912, p. $36 \mathrm{r}$. 
proper - as distinguished from its by-product, opera, - two deserve particular attention. These are the Spanish and the French. Broadly speaking, Elizabethan drama had been but slightly affected by Spanish influences. Tudor dramatists had occasionally introduced Spanish scenes or characters for the sake of variety, and had at times drawn from Spanish sources some suggestions for plot. Later playwrights before the Restoration had borrowed, sometimes directly, but more often indirectly, from Spanish originals. Usually, as in the familiar instance of Fletcher's obligations to the prose of Cervantes, material had been drawn rather from non-dramatic than from dramatic Spanish literature. Under Charles I, there are signs of an interest in Spanish drama which was continued after the reopening of the theatres. Killigrew's early comedy, The Parson's Wedding, successfully produced on the Restoration stage in 1664, drew from Calderon. Adaptations by George Digby, Earl of Bristol, of two comedies by Calderon were acted, according to Downes, ${ }^{1}$ between 1662 and 1665, and the publication of Digby's Elvira, in 1667 , is further proof of his interest in Calderon. Sir Samuel Tuke's Adventures of Five Hours (1663) - in contrast with which Pepys deemed Othello 'a mean thing' - adapted a Spanish play ascribed to Antonio Coello. Other plays during the first decade of the Restoration which seem to show Spanish influence are Dryden's Rival-Ladies (1664) and his Evening's Love (1668), Orrery's Guzman (circ. 1669), ${ }^{2}$ and St. Serfe's

1 Roscius Anglicanus, p. 26.

2 Pepys mentions its anonymous production, 16 April, 1669. Diary, Wheatlcy edition, VIII, 296. 
Tarugo's Wiles (1668). ${ }^{1}$ Translations, such as those of Sir Richard Fanshawe (printed I670-167I) from Antonio de Mendoza, give additional evidences of attention to Spanish drama, but deserve only incidental mention in a record primarily concerned with actual stage productions.

The slender thread of Spanish weave which is thus apparent in the fibre of early Restoration drama is discernible from time to time in the texture of later English drama. Wycherley, Mrs. Behn, and Crowne, in the later seventeenth century, and Steele, Cibber, and Mrs. Centlivre in the early eighteenth century may serve as sufficient examples of the continuance of Spanish influence, however faint at times, upon English dramatists. In general, however, Spanish drama, or even Spanish literature, made but minor contribution to English drama of the Restoration. Apart from its occasional suggestions for plot, Spanish drama may have somewhat stimulated early Restoration tendency toward the comedy of intrigue. In a familiar passage, Scott declared ${ }^{2}$ that 'the Spanish comedy, with its bustle, machinery, disguise, and complicated intrigue, was much more agreeable' to the taste of Restoration audiences than 'regular comedy ... depending upon delicate turns of expression, and nicer delineations of character.' Yet this must not be mistaken for proof of the dominance of Spanish influence over Restoration comedy. From Etherege onward, the 'artificial' Restoration comedy

1 St. Serfe borrowed from Moreto's No puede ser, a source from which Crowne drew to better advantage in his Sir Courtly Nice (1685).

${ }^{2}$ Life of John Dryden, Scott-Saintsbury edition of Dryden, I, 62. 
of manners is largely characterized by a grace and fluency of prose dialogue which, in Congreve, is carried even to indifference toward dramatic action. The bustle and machinery of Spanish comedy actually affected but slightly the course of English dramatic development. The indebtedness of Restoration playwrights to Spanish sources is neither considerable in extent nor potent.

Far more significant in its bearings upon Restoration drama was French influence. French drama, French dramatic theory, and French romance affected English writers of the period so notably that it was once almost habitual to regard Restoration drama as an essentially Gallicized product. In its simplest form, this theory held that Charles II and his followers returned from Cavalier exile on the Continent dominated by French dramatic standards which forthwith gave to English drama its primary stimulus and determined its content, form, and general character. The ease with which proofs may be amassed of direct Gallic influence upon Restoration plays doubtless contributed to the wide acceptance of this facile theory. Its fault lies not in its underlying elements of partial truth, but in its gross exaggeration. It would be an equal error to belittle evidences of French influence upon English drama, some of which are too obvious to escape even a superficial reader. Translations, adaptations, and imitations of French drama are numerous and important. Molière was despoiled by English writers of comedy; Corneille, and later Racine, left indubitable marks upon English tragedy. Potent, especially, was the force of French 
dramatic theory. Yet not even the multiple proofs of Gallic graftings on the stock of Restoration drama can obscure the contention that its roots lie in English soil. The stage which D'Avenant helped to reëstablish owed neither its origin nor its initial progress to Gallic masters. Throughout the interregnum the Elizabethan dramatic tradition persisted. With the reopening of the theatres, the managers of the Patent Houses turned to Shakespeare, Jonson, Beaumont and Fletcher, and other early English dramatists, and in them Restoration playwrights found models to imitate and materials to refashion. Even the novelty of English opera seems chiefly attributable to native influences. Subsequent discussion of the later development of Restoration drama will frankly recognize its large indebtedness to Gallic models, yet even when French authority seems most dominant it never fully imposed its yoke upon the English theatre. The rigid conventions of the classical Continental dramas were, again and again, abated on the freer English stage. In a word, Restoration drama is not to be dismissed as an essentially foreign product. It is the resultant of English and Continental forces.

With this general conclusion always in mind, it is none the less essential to indicate some of the important evidences of French influence upon early Restoration dramatists. The tendency to identify French drama and dramatic theory with the so-called classical school makes it advisable to recall the fact that French drama of the first half of the seventeenth century by no means confined itself to the more 
regular forms of tragedy and comedy. Pastoral and tragi-comedy were popular. The tragi-comedies of the prolific Hardy and of his successor, Rotrou, clearly transgress the strict bounds of Senecan tragedy. The influence of French drama upon English, before the closing of the theatres, was not circumscribed by classical prejudices. In England the doctrines of classical drama, though at times supported, as in the theory of Sir Philip Sidney and in the partial practice of Ben Jonson, had been too rigid for the free fancy of most Elizabethans. As the wave of creative energy subsided, however, playwrights who lacked the genius that is a law unto itself were more susceptible to dramatic guidance. The advent of new and commanding forces in French drama, during the English dramatic interregnum, was naturally of import to the rising dramatists of a reawakening English stage.

To Pierre Corneille (I606-I684) have been largely ascribed the classical tendencies early apparent in English drama of the Restoration. Without disputing the general conclusions of many critics, it may be well to point the danger of regarding him as an uncompromising classicist. The identification of Corneille with classical drama rests on his later dramatic work and theory, but tends to disregard both his earlier plays and the romantic tendencies often apparent even in his so-called classical tragedies. Corneille dramatized before he theorized. Though habitually classed as a writer of tragedy, his 'péchés de jeunesse' - as he termed his early comedies - and Le Menteur broaden the scope of his dramatic work. The roman- 
tic atmosphere of the time colours the splendid rhetoric of $\mathrm{Le} \mathrm{Cid}$ (1636), and the tribute of the Academy to 'la naïveté et la véhémence de ses passions' suggests that its triumph was not that of classical restraint in tragedy. Horace ( 1640$)$, indeed, is a more strictly classical tragedy, but the melodramatic note in Rodogune, the operatic element in Andromède, and the very name comédie heroïque which its author gave to Don Sanche D'Aragon are sufficient proof that Corneille is not to be dismissed merely as a writer of classical tragedy. His important pronouncements of classical dramatic theory, furthermore, belong to his later days. His own practice he found difficult to harmonize with his theory. Yet all this is not to deny his unquestioned influence upon Restoration dramatists in the direction of classical drama. The various Discours and Examens accompanying the printed texts of his plays formulated a critical theory of classical drama which offered direct suggestion to Restoration playwrights. The doctrine of the dramatic unities was to find almost immediately a powerful English advocate in Dryden.

To the influence of Corneille upon English tragedy and dramatic theory must be added that of Molière upon English comedy. Not until the closing decade of the English dramatic interregnum did Molière (I622-I673) attain eminence as a writer of comedy. His significant dramatic work covers the score of years from the production of L'Etourdi ( I $_{553}$ ?) to his death. With Les Précieuses Ridicules, produced late in 1659 , his success was firmly established. In the opening years of the Restoration period, his 
fame was furthered by $L^{\prime}$ École des Maris (I66I) and $L ' E$ cole des Femmes (I662). The advent of the master of French comedy brought to English playwrights of the new era a model to admire and imitate. Some of them had already come in contact with his early work during the closing years of the interregnum. With the reopening of the theatres and the growth of Molière's reputation, English writers turned increasing attention to French comedy. Translations and adaptations of Molière multiplied, and suggestions were freely pilfered for plot, incident, and character. ${ }^{1}$ Yet Restoration borrowers reproduced the outward semblance, not the real spirit, of the French master. In their hands Gallic gaiety was coarsened into gross brutality, satire became cynically harsh, and human comedy lost its humanity. In comedy, as in tragedy, the spirit of French drama evaded the grasp of English copyists. It would be as unfair to Molière as it would be untrue to the facts of English dramatic history to regard Restoration comedy as an essentially Gallicized product.

In the developments of Restoration drama about to be traced, Continental influences will be found constant and powerful. Yet the English influences that dominated the interregnum and the opening years of the new era remain, throughout the Restoration period, the underlying factor. Gallic theory and English practice clashed ceaselessly for years, but in the end the predominant forces were English. Even Dryden, the most notable advocate of classical

1 The extent of English borrowings from French drama is indicated in Ward's suggestive footnote, III, 315-316. 
theories, bore repeated testimony to the triumphs of Elizabethan genius, turned eventually against his 'long-loved mistress Rhyme,' and led the return to English blank verse and an at least partial return to Elizabethan themes and methods. It is well to enter the study of the drama of Dryden and his period with the recollection that the roots of Restoration drama lie in Elizabethan soil. 


\section{CHAPTER IV}

\section{DRYDEN, AND THE HEROIC DRAMA}

THE central figure in the history of Restoration drama is JoHn Dryden ( $163 r-1700$ ). Yet Dryden was more at home in verse satire or prose criticism than in comedy or tragedy. Much of his dramatic work seems written against the grain, in response not to his own impulse, but to the popular demand. He early voiced and long followed the doctrine of the practical playwright :

He's bound to please, not to write well; and knows, There is a mode in plays as well as clothes. ${ }^{1}$

In comedy he had neither the wit nor the ease of Congreve. Even in heroic tragedy, of which he is the chief exemplar, his fancy seems to have been caught rather by rhyme than by dramatic action. Nevertheless, practice gave him facility in playwriting, and the touch of poetry raised his best dramas far above the level of ephemeral stage successes. From flabby perversions of Shakespeare he rose, in All for Love, to real power in handling the theme of Antony and Cleopatra. Though not at heart a dramatist, he led both in critical discussion of dramatic theory and in practice of dramatic composition. With him, essentially, rose and fell English rhymed heroic drama.

1 Prologue to The Rival-Ladies (1664). 
His advent as a playwright promised little. His first comedy, The Wild Gallant (1663), was to Pepys 'so poor a thing as I never saw in my life almost,' ${ }^{1}$ and to the author himself a 'motley garniture of fool and farce.' ${ }^{2}$ The Rival-Ladies (I664), based on a Spanish plot, is a tragi-comedy with elements of heroic drama. Especially noteworthy is the introduction of some scenes in rhyme. Dryden, whose carelessness is shown by his citation of Queen [sic] Gorboduc, a blank-verse tragedy, as a precedent for English rhymed drama, and by his assignment of the invention of blank verse to Shakespeare, in dedicating his play to the Earl of Orrery credits him with an earlier adoption of the 'new way ... of writing scenes in verse.' Roger Boyle, EARL OF ORRERY (I62I-I679), of whose work The History of Henry the Fifth (1664) and Mustapha, the Son of Solyman the Magnificent (1665), may serve as sufficient examples, has been frequently credited with the introduction of rhymed heroic drama, but it is well not to lay too much stress on Dryden's generous words. It is true that 'the new way of writing scenes in verse' differs widely from the Elizabethan use of the rhymed couplet to mark the close of scenes or to emphasize certain passages, and from Shakespeare's frequent employment of rhyme for lyrical effect in his earlier plays. Yet even the more rigid 'heroic couplet' of Restoration drama is perhaps anticipated in such a play as The Virgin Widow (printed I649), by Francis Quarles. Although this appeared during the interregnum,

1 Diary, 23 Feb., 1663. Wheatley edition, III, 51 .

2 Second Epilogue, written for the revival of the play in 1669. 
the first quarto speaks of it as 'having been sometimes at Chelsie privately Acted,' and the fact that one of its most conspicuous rhymed passages receives extended parody in The Rehearsal (167I) ${ }^{1}$ seems to strengthen belief that the play should not be dismissed as a 'closet-drama.' Dryden himself ascribes to D'Avenant the introduction of rhymed couplets on the stage. It may, furthermore, be questioned whether Orrery's plays preceded Dryden's in actual employment of the rhymed couplet on the Restoration stage. $^{2}$ Orrery certainly exhibits an early tendency toward the use of the 'heroic couplet' in serious drama, but Dryden's adoption and development of rhyme was the dominant factor in its notable, though brief, triumph.

Although rhyme makes an early appearance in less serious plays like The Rival-Ladies and Etherege's Comical Revenge (1664), its real supremacy was to come in tragedy. With The Indian Queen (1664), in which Sir ROBERT HOWARD (1626-r698) had some assistance from Dryden, and especially with Dryden's sequel, The Indian Emperor, or The Conquest of Mexico by the Spaniards (1665), rhymed heroic tragedy comes into full being. The Indian Emperor gave an adequate test of the heroic couplet in serious drama and established Dryden's position as a dramatist. In the conflicts of love and honour

1 Quarles, The Virgin Widow, III, I, is burlesqued in The Rehearsal, III, 2. See Arber's reprint of The Rehearsal, pp. 86-88.

2 Pepys, who saw Orrery's Henry the Fiflh, I3 Aug., 1664, speaks of it as 'the new play.' He mentions The Indian Queen, 27 Jan., 1664, and he saw The Rival-Ladies, 4 Aug., 1664. 
between characters of high rank, including personages like Montezuma and Cortez, who move, before a foreign and semi-historical background, through scenes of stirring incident toward the triumphant union of martial hero and angelic heroine and the death of those unable to survive the tragic stress, Dryden assembled many elements of earlier English plays, and wedded heroic action to the heroic couplet by the new formula of 'heroic drama.'

The new species of drama was now fairly established, but Dryden did not wholly abandon comedy. Yet despite the light under-plot of Celadon's love for Florimel which Nell Gwynn helped to popularize, Secret Love, or The Maiden Queen (1667) shows in its main plot influences of heroic drama in both form and substance. The love conflict involved in the Queen of Sicily's affection for her sister's lover, and solved by the Queen's renunciation, is essentially heroic in theme and employs the heroic couplet as well as blank verse. Probably in the same year, 1667 , Dryden produced versions both of Continental and of Elizabethan plays. Sir Martin Mar-All, or The Feigned Innocence is a prose adaptation of Molière's L'Étourdi, with some borrowings from Quinault which accentuate Dryden's indebtedness to French sources. In The Tempest, or The Enchanted Island, ${ }^{1}$ the tempest of Restoration perversion of Shakespeare breaks with violence, and the enchantment fades into the light of common day. An Evening's Love, or The Mock Astrologer (r668) coarsens materials drawn

1 Probably most of the work belongs to D'Avenant, whom Dryden aided. This play must be distinguished from Shadwell's opera, I673. 
from the younger Corneille and from Molière's Le Dépit Amoureux. Its most engaging characters, Wildblood and Jacintha, resemble, if they do not match, Celadon and Florimel. Perhaps Dryden's most agreeable contributions to comedy are, in fact, these pairs of light-hearted lovers, who, without the deeper traits of Benedick and Beatrice, have yet real vivacity and superficial attraction. The range and variety of these different plays show not merely Dryden's versatility as a dramatist but the contending forces that bear on Restoration drama.

The conflict between Continental example and English practice may be seen especially in the English treatment of heroic drama. Emphasis has already been laid upon the continuous development from early English sources of many important elements in heroic drama. Into this current now poured French streams. The heroic romances of such authors as La Calprenède and Madeleine de Scudéry influenced English drama not merely indirectly, through the French drama which they stimulated, but in many cases directly. 1 Yet English heroic plays usually reproduced but imperfectly the French romances or plays which were their models. Whatever their professed allegiance to Corneille's theories as to the dramatic unities, the Restoration dramatists by no means caught either the spirit or the form of Corneille's tragedies. Observation of French models resulted, in the English heroic play, in simplification of character, scene, and action rather than in absolute observance of the unities of

1 Ward, III, 309 , footnote 2 , gives a suggestive list of instances in point. 
time, place, and action. ${ }^{1}$ The grand manner of French heroic romance was distorted rather than copied; its themes handled grossly. Honour was put to the proof of sensational and impossible adventure, and love exploded in a torrent of rhetoric. Hero and heroine must tear a passion to tatters and out-Herod Herod. It is a far cry from The Indian Emperor to Le Cid. Classical French doctrine sought to separate tragedy from comedy, but its effect on English drama was somewhat inconclusive. There resulted, indeed, stricter discrimination between comedy and tragedy in Restoration than in Elizabethan drama. Yet the tragi-comedies of Beaumont and Fletcher maintained their stage popularity, and no doubt influenced the happy endings of numerous heroic plays. The French distaste for bloodshed and violence on the stage could not be transmitted undiminished to an English stage that had tasted the tragedy of blood. In writing The Indian Emperor as a sequel to The Indian Queen, Dryden was forced to confess a certain paucity of materials, 'there remaining but two of the considerable characters alive.' ${ }^{2}$ The heroic drama almost required the eventual triumph of the superhuman hero, but victims were needed to exhibit his prowess. It is not surprising, therefore, that English heroic drama remains frequently closer to the type of Elizabethan tragi-comedy than to classical tragedy. At almost every turn, there is discernible a conflict between foreign classical restraint and native

1 The use of increasingly elaborate scenery was also a factor in the simplification in number of scenes.

${ }^{2}$ Scott-Saintsbury edition of Dryden, II, 32 I. 
romantic freedom. In this conflict, Gallic theory is not translated literally into English practice.

In one particular, this clash of forces seems to have resulted, at least temporarily, in a decisive French victory, in the introduction of rhyme in serious English drama. That French example is wholly responsible for this innovation in the English heroic play seems, however, hardly tenable. The precision and regularity of the rhymed couplet might, conceivably, have recommended it to Restoration taste, even without the authority of the Alexandrines of French drama. The couplet which commended itself to Jonson and which had already been approved in non-dramatic verse had received some trial in an interregnum play by Quarles. French seed fell upon good soil, and the estimate of its yield should not ignore the favourable season in which it ripened. There need be little hesitation, however, in admitting the definite and potent French influence toward rhymed drama. Under the Merry Monarch, when 'all, by the king's example, lived and loved,' ${ }^{1}$ there was royal precedent for acceptance of Continental dramatic tendencies. In speaking of his rhymed tragedy, The Black Prince, as 'wrote in a new way,' Orrery says that he wrote 'in the French Manner, because I heard the King declare himself more in favour of their Way of Writing than ours.' 2

The general adoption of rhyme in serious English drama was not effected without a struggle. The

1 'All, by the King's Example, live and love,' The Progress of Beauty, George Granville, Lord Lansdowne, Genuine Works, 1732, I, 78.

${ }^{2}$ Quoted by Ward, III, 340. 
various stages of the notable controversy on the subject between Dryden and Howard are tersely summarized in the last paragraph of Dryden's Defence of an Essay of Dramatic Poesy (I668): 'In my epistle dedicatory, before my Rival Ladies, I had said somewhat in behalf of verse, which he was pleased to answer in his preface to his plays [Foure New Plays, 1665]: that occasioned my reply in my Essay [ $A n$ Essay of Dramatic Poesy, r668]; and that reply begot this rejoinder of his, in his preface to the Duke of Lerma [1668].' The essence of Howard's argument is that rhyme is unnatural in drama. Dryden's position is that, in serious plays, rhyme is 'as natural and more effectual than blank verse,' ${ }^{1}$ for it 'circumscribes the fancy' ${ }^{2}$ and adds sweetness, that the faults of rhymed tragedy are due to 'ill rhyming,' and that Jonson, Fletcher, and Shakespeare have so thoroughly exhausted dramatic writing that 'this way of writing in verse they have only left free to us.' 3 To such arguments Dryden's own abandonment of rhyme within the next decade gives sufficient answer, but for the moment, putting theory into practice, he set the fashion of rhyme.

In Tyrannic Love, or The Royal Martyr (I669) and Almanzor and Almahide, or The Conquest of Granada by the Spaniards (1669-1670), the heroic drama has characteristic illustration. In Tyrannic

${ }^{1}$ Essay of Dramatic Poesy, Ker, I, 94. It should be noted that the discussion of rhyme forms but part of this Essay, which deals at length with the unities and with the relative merits of ancient and modern dramatists.

2 Dedication to The Rival-Ladies.

$8 \mathrm{Ker}, \mathrm{I}, 99$. 
Love, Maximin, Tyrant of Rome, chooses Porphyrius as his heir and as husband for his daughter, Valeria. Porphyrius, in love with the Empress herself, refuses the match and is sentenced to death. Catherine, Princess of Alexandria, a Christian captive, who converts the heathen philosopher Apollonius and others with remarkable celerity, captures Maximin's heart. A conjurer is consulted to win Catherine for the Tyrant, but her guardian angel wards off the evil spirits. Maximin then orders Catherine and her mother to be killed on account of their religion, and the Empress and her lover are sentenced to death. Valeria stabs herself in despair, her lover Placidius stabs Maximin, and he in turn stabs Placidius - a 'solution by massacre' which eventually leaves Porphyrius and the Empress free to mount the bloody throne. Though it is easy to exaggerate the defects of the heroic drama, some of Maximin's speeches are almost proverbial for rant, and the solution certainly takes the step from the sublime to the ridiculous. After Placidius and Maximin have exchanged stabs, 'Placidius falls, and the Emperor staggers after him, and sits down upon him.' Disdaining the help of guards, Maximin strives to rise but has to resume his uneasy seat of vantage upon Placidius, who heroically rounds out a defiant couplet. Both are finally rhymed to death.

Placmius. Oh I am gone. [Dies.] Maximin. And after thee I go,

Revenging still, and following ev'n to the other world my blow;

[Stabs him again.]

And shoving back this earth on which I sit, I'll mount, and scatter all the gods I hit. [Dies.] 
Valerius, Valeria, Maximin, and Placidius meet death on the stage, contrary to the classical tendency. On the other hand the Empress and her lover have a happy issue out of their afflictions. The classical influence is evident in the attitude toward the three unities. The unity of place is well preserved, except in the shift of scene in the fourth act, and the action is simplified to a few leading characters. But in order to conform to the unity of time, the action has to proceed sometimes with remarkable celerity. The Tyrant's son does battle, is killed, and is greeted with his dead march, within some sixty lines. In the second act, Apollonius, the heathen philosopher, despite his own excellent argument, is converted with theatrical speed. 'Time trots hard' with heroic drama.

The Conquest of Granada is perhaps the typical heroic drama. It is based largely on Madeleine de Scudéry's Almahide, and partly on her Le Grand Cyrus and Ibrahim. Like Marlowe's Tamburlaine, it is in two parts, and centers in the character of the hero. The plot is a maze through which Almanzor advances with assured tread. ${ }^{1}$ In the Dedication, Dryden says, 'I have formed a hero, I confess, not absolutely perfect, but of an excessive and over-boiling courage; but Homer and Tasso are my precedents.' For rant, Almanzor 'out-Herods Herod,' and for prowess one shudders to contemplate his meeting with Achilles or Rinaldo, his confessed originals. ${ }^{2}$ Once only, when he is overcome in the last act of Part I,

1 An excellent summary of it is in Saintsbury's Dryden, pp. 46-50.

' Essay of Heroic Plays, Ker, I, I55. 
the hero seems human. Doctor Johnson says ${ }^{1}$ that the two parts of the play 'are written with a seeming determination to glut the publick with dramatick wonders; to exhibit in its highest elevation a theatrical meteor of incredible love and impossible valour, and to leave no room for a wilder flight to the extravagance of posterity.' Nevertheless, despite bombast and grotesqueness, a certain masterful vigour sweeps the action onward. Spirited couplets help to sustain the dialogue, and the vitality of the central character is abundant enough to impel him triumphantly through double the ordinary number of acts of heroic drama. Yet when the curtain falls on the last of many scenes of battle, murder, and sudden death, one recalls with amazement Dryden's definition of a play as 'a just and lively image of human nature.' 2

The zeal of the heroic play seems for a time to have eaten Dryden up. In the Epilogue to The Conquest of Granada he speaks with the extravagance of his own Almanzor. Dryden had once been content to claim 'a mingled chime Of Jonson's humour, with Corneille's rhyme,' ${ }^{3}$ but now he extols his own age far above that when

Jonson did mechanic humour show, When men were dull and conversation low.

The Elizabethans, who 'rose, but at their height could seldom stay,' could not meet the test of Restoration refinement, for

1 Life of Dryden. In Lives of the English Poets, Hill edition, 1905, I, 348-349.

2 Essay of Dramatic Poesy, Ker, I, 36.

'Prologue to Secret Love (printed 1668). 
Wit's now arrived to a more high degree;

Our native language more refined and free.

But while Dryden was viewing with complacency his good fortune in writing 'to please an age more gallant than the last,' and asserting with easy assurance the merits of rhymed heroic drama, profane hands had been quietly laying a mine of satire which was presently to explode under his feet. The Rehearsal, said to have been begun in 1663 , was produced 7 December, I67I. Its chief author, George VIlliers (I6281687), the graceless Duke of Buckingham, had been assisted by Martin Clifford, Thomas Sprat, and, it is sometimes said, by 'Hudibras' Butler. In the years of its conception it had accumulated a varied body of ridicule upon contemporary drama and dramatists. The main attack, doubtless first directed against D'Avenant, ${ }^{1}$ was diverted after his death, in r668, to Sir Robert Howard, and finally to Dryden, the new poet laureate. Though by no means the sole target, Dryden received most of the shafts of burlesque. Drawcansir, hero of the mock-heroic tragedy which is rehearsed, is Almanzor, and Bayes, the author, is Dryden himself. Many of Dryden's lines are closely parodied :

Almanzor: Spite of myself I'll stay, fight, love, despair; And I can do all this, because I dare.

DRAWCANSIR: I drink, I huff, I strut, look big and stare; And all this I can do, because I dare.

1 Bayes, whose broken nose adorned with a 'wet piece of brown papyr' (II, 5) is a hit at D'Avenant's personal disfigurement, retains evidences of the original intention. 
And again :

Almanzor: He, who dares love, and for that love must die, And, knowing this, dares yet love on, am I.

DrawCANSIR: He that dares drink, and for that drink dares die,

And, knowing this, dares yet drink on, am I. ${ }^{1}$

Almahide, Dryden's heroine, has her 'So, two kind turtles, when a storm is nigh' transprosed into 'So Boar and Sow, when any storm is nigh.'

Dryden, though the most conspicuous, is by no means the only dramatist held up to ridicule. Fanshawe, Quarles, and Stapylton are among the lesser dramatists who are not overlooked in specific passages of parody. Indeed, the burlesque overflows with so many 'local hits' and so many close parodies of forgotten plays that much of the fun is now lost. Burlesque, in its very nature, is ephemeral, and can hardly survive the subject it ridicules. The vitality of parts of The Rehearsal is due to the general satire of stage absurdities common to all time. Uncalled for exits and entrances, omissions in the plot of vital points, rant and fustian, are subjects for lasting satire. Parts of The Rehearsal move even the modern reader's mirth - Volscius in love, with one boot on and the other off, torn between Honour urging him to 'pluck both boots on' and Love urging him to 'put on none'-Pallas, with French wine in her lance, a pie in her helmet, and a buckler of cheese-Drawcansir who 'kills 'em all on both sides,' and boasts :

Others may boast a single man to kill;

But I, the bloud of thousands, daily spill.

1 See Arber's reprint of The Rehearsal, pp. 102-103. 
Sheridan's Critic has displaced on the stage the earlier burlesque which served as its rough model, but The Rehearsal yet retains much of its zest for the reader familiar with the extravagant absurdities of heroic drama.

The actual effect of The Rehearsal in its own day has often been greatly misrepresented. Short-lived the heroic drama doubtless was, but its death-knell had not yet been sounded. Probably the authors of The Rehearsal cared little whether heroic plays were laughed off the stage, so long as their piece was laughed at on the stage. They had no insistent artistic quarrel with the reigning favourite, and none of Jeremy Collier's saeva indignatio in exposing the shortcomings of the drama. Amid the laughter evoked by The Rehearsal, Dryden published An Essay of Heroic Plays (I672), in the opening sentence dogmatically reasserting his attitude toward rhymed plays: 'Whether Heroic Verse ought to be admitted into serious plays, is not now to be disputed: 'tis already in possession of the stage; and I dare confidently affirm that very few tragedies, in this age, shall be received without it.' With zeal worthy of a better cause, he still stood to his guns, maintaining that 'an heroic play ought to be an imitation, in little, of an heroic poem; and, consequently, that Love and Valour ought to be the subject of it'; that 'an heroic poet is not tied to a bare representation of what is true, or exceeding probable'; that the introduction of magic machinery is justifiable; and that the 'frequent use of drums and trumpets, and my representations of battles' had Shakespearean precedent, and were essential to heroic drama. 
Dryden's somewhat desultory dramatic efforts during the next few years do not justify in practice his positiveness in theory. The Prologue to Amboyna, or The Cruelties of the Dutch to the English Merchants (I673) justly warns the audience to 'hope not either language, plot, or art,' and the sorry tragedy, deprived even of the false gallop of verse, shuffles through bad prose and worse blank verse to its wretched end. There followed an operatic version of Paradise Lost, entitled The State of Innocence and Fall of Man (printed r674), which was not intended for the stage. Criticism has fastened more readily upon the ludicrous than upon the sometimes fine passages. Yet Eve's pride that goeth before the fall shows a mastery of the personal pronouns hardly consonant with the State of Innocence:

Sure, I am somewhat which they wish to be, And cannot; I myself am proud of me. (II, 2)

Meantime, Dryden had not abandoned comedy, though The Assignation, or Love in a Nunnery (1672) tends to confirm his own admitted weakness in such work. Marriage-da-la-Mode (I672?), a comedy with a serious under-plot, is, however, of a different stamp, and has been pronounced by Saintsbury ${ }^{1}$ 'Dryden's only original excursion into the realms of the higher comedy.' Melantha, a fashionable lady, 'runs mad in new French words,' and perhaps foreshadows in spirit Congreve's Millamant, to whom she has sometimes been compared.

In 1675, appeared the last of Dryden's rhymed 
heroic plays, Aureng-Zebe. Already his spirit is restive under the fetters of rhyme. In the Dedication he desires that, if he 'must be condemned to rhyme,' he may find 'some ease in his change of punishment,' and in the Prologue he confesses that he 'grows weary of his long-loved mistress, Rhyme.' Instinct is struggling against respect for classical forms and conventions. Though he still implies that his own age excels Shakespeare's in literary art and finish, his lines are now in marked contrast to his earlier vaunts :

But spite of all his pride, a secret shame

Invades his breast at Shakespeare's sacred name:

Awed when he hears his god-like Romans rage,

$\mathrm{He}$, in a just despair, would quit the stage;

And to an age less polished, more unskilled,

Does, with disdain, the foremost honours yield.

Yet Aureng-Zebe has less rant and fustian than The Conquest of Granada, and sometimes strikes the note of true poetry. ${ }^{1}$ Heroic drama is tempered with some suggestion of Gallic restraint. The heroic couplet in drama needed, however, more than halfhearted support. When Dryden lost confidence in his theory, it was in vain that he continued a constantly more repugnant practice. When in All for Love ( 1678 ) he turned to blank verse and a Shakespearean theme, rhymed heroic drama had had its day and practically ceased to be.

The modern critical attitude toward the English rhymed heroic play has sometimes been only less

${ }^{1}$ Quotation has not staled the fine passage beginning 'When I consider life, 'tis all a cheat,' IV, I. 
unsympathetic than that of The Rehearsal. So patent are the gross excesses of heroic drama that some have thought its substance mere rant and fustian, and its form rhyme without reason. Nowhere, indeed, are absurdities easier to find; never, perhaps, has it been easier to laugh a case out of court. Yet the ends of dramatic justice would not be defeated by recommendations to mercy. The failure of heroic drama lay in its attempt to achieve the impossible. Its reach exceeded its grasp, but the effort was not ignoble. Dramatists aimed at the grand, and hit the grandiloquent. With them the 'grand manner' became what Scott, in another context, called the 'big bow-wow' style. If there is but a step from the sublime to the ridiculous, it is filled by the grotesque. Yet if heroic drama is grotesque, it is unfair to regard only its comic facet. Beneath the grin of a mediæval gargoyle may lurk a tragic shadow, and the Devil of the Mystery plays may touch more than the laughter of the groundlings. Love and honour - the unvarying themes of heroic drama - are not comic. It is only the angle of vision that makes them sometimes appear so. Possibly it is not idle fancy to read between the lines of heroic drama the tragedy of lost romance. The Fountain of Youth that flowed free for the Elizabethans had run dry, but its tradition had not been wholly forgotten. If exiles from the court could no longer fleet the time carelessly in the Forest of Arden, as they did in the golden world, perhaps they sometimes turned eagerly from the jaded London world to distant lands where fiction outran fact, and fancy still 
was free. The heroic dramatist failed to prove that it was an easy task to pluck bright honour from the pale-faced moon, but despite that failure, he echoes faintly an earlier faith in chivalry and love. Noubtless it was a sorry age that confused grandeur with sheer bulk, and mistook that which glitters for gold. Doubtless heroic tragedy merits, in no small degree, the measure that has been meted out to it. But though its heroes can no longer hope to touch the Happy Isles, and see the great Achilles, there yet remains beneath the tinsel of heroic drama some work of noble note not unbecoming men that strove with Gods.

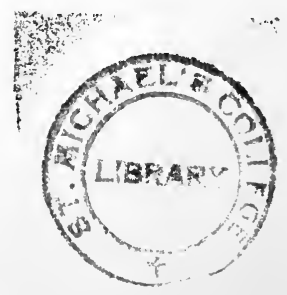




\section{CHAPTER V}

\section{ETHEREGE AND WYCHERLEY (SHADWELL)}

WHILE heroic drama fought its rivalries of love and its valorous sieges and conquests in far-away lands of incredible adventure, Restoration comedy was busy with familiar themes and scenes. As tragedy moved farther and farther from ordinary life and adopted the unfamiliar accent of verse, comedy descended from romance to realism and found easiest expression in prose. The increasing divergence between the paths of tragedy and comedy seems in harmony with the classical tradition that sought to separate them. But Gallic influence did not prevail to the exclusion of tragi-comedy. Heroic drama frequently averted tragedy from its heroes, and comedy often blended more serious matter with lighter themes. Habitually, heroic tragedy uses rhyme, and comedy prose, yet early tragi-comedies of Dryden and Etherege experiment with rhyme, and tragedy, even during the dominant period of rhyme, sometimes employs prose as well as blank verse. Dramatists, like Dryden, who preferred tragedy, also wrote comedy; comic dramatists, like Congreve, essayed tragedy.

In D'Avenant's revival of drama during the interregnum the emphasis had fallen on the side of more serious drama. With the opening of the theatres, 
comedies of Ben Jonson reappeared on the boards and stimulated dramatists like Wilson. The influence of Elizabethan romantic comedy, and still more of romantic tragi-comedy, so far as it persisted, was diverted chiefly toward heroic drama. Some of the comedies of Middleton, Rowley, and Brome, however, as well as those of Ben Jonson, may be regarded as Elizabethan forerunners of the realistic tendencies of Restoration comedy. In an age that exalted wit rather than humour, and external form rather than innate genius, it was natural for drama to turn to the comedy of manners. In this tendency, a potent force was the influence of the court. The Patent Theatres held their license from the King, and playwrights sought the patronage of nobles rather than the support of the public. Under the Merry Monarch, drama found its most characteristic expression in comedy. ${ }^{1}$ Comedy mirrored not English nature, still less human nature, but the nature of the court. Elizabethan comedy had been national; Restoration comedy was local. Not to know London was to argue yourself unknown. Restoration comedy was 'artificial,' not in Lamb's sense that it dealt with an unreal Utopia, but in that it arbitrarily narrowed the range of comedy, and found love synonymous with fashionable intrigue.

Although the comedy of manners developed in Elizabethan days, the 'society comedy' of the Restoration may conveniently be regarded as a new school.

${ }^{1}$ Crowne, Dedication to Sir Courtly Nice, r685 quarto: 'The greatest pleasure he [i.e. 'our late most Excellent King'] had from the Stage was in Comedy, and he often Commanded me to Write it.' 
Its real founder has usually been held to be 'gentle GeORGE' ETHEREge (r634-r635?-r69r?). Handling the comedy of manners with Gallic grace and ease stimulated by residence in France, Etherege vividly portrays the outward brilliancy of fashionable London. His gallants and fops breathe the atmosphere of Restoration society, and reflect, though with greater wit, the talk and thought of the beau monde.

Pepys pronounced Etherege's first play, The Comical Revenge, or Love in a Tub (I664), 'very merry.' 1 The merriment - a comic underplot in which two gamesters translate the Elizabethan art of cony-catching into Restoration 'bubbling' - is blended with a romantic love plot. Two pairs of lovers are involved in cross purposes and complications not unlike those of Midsummer Night's Dream, and unhappily with no magic philtre to aid in the solution, which has finally to be effected by a sort of tour d'amour. A noteworthy feature of the play is the deliberate adoption of rhyme in the heroic love plot, ${ }^{2}$ but the spirit of Elizabethan romance could not thus be wooed back. How far poetic imagination had departed from the drama may be seen in Colonel Bruce's speech when he learns that Graciana has given her love to another:

Fate, thou hast done thy worst, thy triumph sing;

Now thou hast stung so home, thou'st lost thy sting.

I have not power, Graciana, to exclaim (After a pause)

Against your fault ; indeed you are to blame. (III, 6)

1 Diary, 4 Jan., 1665. Wheatley edition, IV, 325.

2 Dryden's Rival-Ladies (1664) also employs rhyme somewhat. 
The comic underplot suggests Gallic influence. Dufoy, the saucy French valet, is doubtless a descendant of the Mascarille of Molière's pre-Restoration comedies. ${ }^{1}$ The local colour is very vivid in an effective tavern scene (II, 3 ), in the mention of resorts familiar to Samuel Pepys, like the Fleece tavern and The Rose, and especially in the evidences of Cavalier feeling in the sneers at Cromwell and his followers. Sir Nicholas Cully is 'one whom Oliver, for the transcendent knavery and disloyalty of his father, has dishonoured with knighthood' (I, 2), and when Wheedle seeks to cozen him through flattery, it is by suggesting that he is the ideal gallant - 'the prettiest, wittiest, wildest gentleman about the town, and a Cavalier in your heart, the only things that take her' (IV, 2). Some of the prose dialogue suggests the piquancy and sprightliness of Etherege's later comedy.

Etherege's second play, She Would if she Could (I668), emphasizes the characteristics of 'society comedy.' Freeman and Courtall are a typical pair of gallants whose daily round of life, as Gatty tells them, consists in 'every moment rattling from the eating-houses to the playhouses, from the playhouses to the Mulberry Garden' (II, I). A bit of their own dialogue shows the Restoration view of honour:

Courtall. Fie, fie, the keeping of one's word is a thing below the honour of a gentleman.

FrEeman. A poor shift! fit only to uphold the reputation of a paltry citizen. (II, 2)

Lady Cockwood's defence of her own conduct really supplies the picture of the lady of fashion: 'Were ${ }^{1}$ Gosse, Seventeenth-Century Studies, p. 240. 
I every day at the plays, the Park, and Mulberry Garden, with a kind look secretly to indulge the unlawful passion of some young gallant; or did I associate myself with the gaming madams, and were every afternoon at my Lady Briefs and my Lady Meanwell's at ombre and quebas, pretending ill luck to borrow money of a friend, and then pretending good luck to excuse the plenty to a husband, my suspicious demeanour had deserved this' (III, 3). The charms of the town and the horrors of the country are portrayed in the very spirit of the Memoirs of Count Grammont.

Etherege's dramatic masterpiece is unquestionably The Man of Mode, or Sir Fopling Flutter (I676). Sir Fopling Flutter 'lately arrived piping hot from Paris,' with six footmen with French names, with French phrases at his tongue's end, and French dances at the tips of his toes, is one of the most notable character types of Restoration comedy. He is an ancestor of Lord Foppington, Sir Courtly Nice, and many other fops. The Man of Mode reflects the usual contempt for the country. Dorimant asserts to Harriet as the highest proof of his affection that to be with her he could live in the country 'and never send one thought to London.' But Harriet cannot believe the incredible: 'Whate'er you say,' she rejoins, 'I know all beyond High Park's a desert to you, and that no gallantry can draw you farther' $(V, 2)$. She herself, however, is even willing to be 'mewed up in the country again . . . rather than be married to a man I do not care for.' Many of Harriet's scenes are typical of Etherege's piquant 
dialogue, such as that in which she makes light of Dorimant's advances (IV, I), or the one (III, I) where she and Young Bellair pretend love to deceive their parents - a situation not unlike that in Goldsmith's She Stoops to Conquer, where Tony Lumpkin and Miss Neville deceive Mrs. Hardcastle by pretended billing and cooing. So vividly does The Man of Mode mirror the Restoration court that Dorimant has sometimes been held to portray Lord Rochester ${ }^{1}$ Medley, Sir Charles Sedley; and Sir Fopling, 'Beau' Hewitt.

Etherege has not always received full recognition for his services to the drama. Leigh Hunt's failure to include him with Wycherley, Congreve, Vanbrugh, and Farquhar in his edition of the comic dramatists of the period may perhaps have had its effect. The intrinsic value of Etherege's work is lessened, to be sure, by obvious dramatic defects. $\mathrm{He}$ is weak in plot construction and in dramatic action; lacking deep emotional power, he glosses over shallowness with a superficial veneer of easy flippancy; he turns comedy, from lashing vice with ridicule, to laughter at $\sin$ as well as at folly. Historically, however, his work has marked importance. In the early introduction of rhymed verse, in the development of light and graceful prose dialogue, animated with wit that sometimes rises to brilliancy, in the establishment of a type of 'society comedy' which led to Congreve and Sheridan, and in vivid reproduction of the atmosphere

${ }^{1}$ Spence's Anecdotes, Malone edition, I820, p. I 6 6, however, quotes Lockier as saying that Etherege 'designed Dorimont [sic], the genteel rake of wit, for his own picture.' 
of the Restoration beau monde, Etherege is entitled to high regard both for his actual achievements and for what he heralded.

A strong claimant to some of the honours of early Restoration comedy which seem more properly to belong to Dryden and Etherege was William WYCHERLEY (I640?-I 7I6). The story that Wycherley as a veteran had told the juvenile Pope that he had composed his comedies at very early dates is, unfortunately, based on the unreliable authority of Spence's Anecdotes, but it at least suggests Wycherley's jealousy of the prior claims of other early comic writers. Pope is thus quoted by Spence: 'The chronology of Wycherley's Plays I was well acquainted with, for he has told me over and over. Love in a Wood he wrote when he was but nineteen; The Gentleman Dancing-Master at twenty-one; the Plain Dealer at twenty-five; and the Country Wife at one or two-and-thirty.' ${ }^{1}$ If Wycherley wrote Love in a Wood at nineteen, it would antedate the Patent Theatres, but it is against probability that the various plays remained so long in manuscript, and that all the allusions to later events were inserted in final revisions for later stage presentation. Yet, if Wycherley must yield the priority which he probably coveted, he surpasses earlier comic dramatists of the Restoration in power and dramatic skill. In his hands, comedy is grasped with brutal but undeniable force, and dragged relentlessly through the mire of animalism. For some years, especially while Dryden was devoting his best energies to heroic drama, and

${ }^{1}$ Spence's Anecdotes, Malone edition, 1820, p. 125. 
Etherege was so far indulging in his 'crying sin, idleness' as to lead Rochester to rebuke 'his long seven years' silence,' 1 Wycherley was the central figure of Restoration comedy.

From the outset, Wycherley borrowed freely. Love in a Wood (I67I ?) owes to Molière ${ }^{2}$ a debt not unnatural in a writer who had resided in France before the Restoration. Probably Wycherley took hints also from Sir Charles Sedley's The Mulberry Garden (I668), and the scene in 'St. James's Park at night' (II, I), where Vincent and Dapperwit pursue Lady Flippant and Lydia, recalls Etherege's Mulberry Garden scene in She Would if She Could (II, I), where Freeman and Courtall pursue Ariana and Gatty. The dramatis personce are for the most part Jonsonian 'humour' characters. Ranger, Dapperwit, ${ }^{3}$ Alderman Gripe, and Lady Flippant are obviously significant names, and, for that matter, it is hardly necessary to define Mrs. Joyner as 'a Match-maker,' or Mrs. Crossbite as 'an old cheating jill.' The general setting in which these characters move is sufficiently suggested in Lady Flippant's speech: 'Have I not constantly kept Covent-Garden church, St. Martin's, the playhouses, Hyde Park, Mulberry garden, and all the other public marts where widows and maids are exposed ?' (I, I), and the usual moral attitude by her indignant exclamation, ' $F y$ ! madam,

${ }^{1}$ Rochester's Session of the Poets (1675). The lines may have prompted Etherege to write The Man of Mode (r676).

${ }^{2} L ' E ́ c o l e ~ d e s ~ M a r i s$ and L'École des Femmes, Ward, III, 463.

8 The description of the various kinds of wit in the conversation between Dapperwit and Lydia (II, r) seems a reminiscence of Touchstone's seven degrees of the lie. 
do you think me so ill bred as to love a husband?' (III, 4).

The Gentleman Dancing-Master (I67I) shows Continental influences upon Wycherley's work. 'Mr. Paris, or Monsieur de Paris, a vain coxcomb, and rich city heir, newly returned from France, and mightily affected with the French language and fashions,' is an earlier Sir Fopling Futter. The dancing-lesson scenes seem derived from Calderon's El Maestro de Danzar. But French and Spanish sources do not supply the English immorality. The conversation in the opening scene between Hippolita and her maid Prue shows the chasm that separates the ingénue of French drama from her Restoration counterpart. What the Restoration age thought of itself has excellent definition in Hippolita's phrase, 'By what I've heard, 'tis a pleasant, well-bred, complaisant, free, frolic, good-natured, pretty age' (I, I). And what London thought of the country appears in her remark to Gerrard, 'What young woman of the town could ever say no to a coach and six, unless it were going into the country' (III, I).

In The Country Wife ( 1673 ?), Wycherley reveals at once perhaps the height of his dramatic power and the depth of his moral degradation. Borrowing from Molière's L'École des Femmes something of the general situation for his main plot, he transformed the real ingénue Agnès into Mrs. Pinchwife, whose nominal purity at the outset is due to lack of opportunity to sin. The progress of her corruption when she is transferred from the country to the fashionable world of London is detailed without sympathy either 
for the degraded wife or for the dishonoured husband. Horner, who prosecutes his vices through an assumption perhaps the most atrocious in all Restoration comedy, is Wycherley's real hero. Ingenuity is prostituted in the service of animal license. From Molière's L'École des Maris, Wycherley took the device of making an unsuspecting lover the bearer of a love letter to another, but in his hands the mild deception of a would-be husband becomes grim tragedy, when Mrs. Pinchwife makes her husband the bearer to Horner of the message of his own dishonour. And when, at the end of the play, Pinchwife remains unconscious of the ruin wrought, and the curtain falls to a mocking dance of cuckolds, one sees the gulf between even the lowest decadence of Elizabethan drama and what the Restoration age termed 'comedy.'

Yet, when The Country Wife could not longer be tolerated on the stage, Garrick was able to recast some of the material of the play in The Country Girl, which continued to hold the stage and has had modern revivals. Even more striking is the fact that, in The School for Scandal, Sheridan, in the story of Sir Peter and Lady Teazle, handled essentially the same general situation, but in a different atmosphere. Like Mrs. Pinchwife, Lady Teazle is a 'country wife' who is plunged into the sea of temptation in London society, but she is rescued from the waves which submerge Mrs. Pinchwife.

The Plain Dealer (I674) furnishes the best illustration of Wycheley's indebtedness to French drama. 'Manly, the 'plain dealer,' is so obviously taken from 
Molière's Le Misanthrope as to make it seem remarkable that Wycherley could borrow from Molière so much of the letter, and so little of the spirit, of his work. The verbal parallels are sometimes so close as to be literal translation. ${ }^{1}$ Sincerity in word and deed is the motto of both Manly and Alceste. Both are merciless to flatterers, both object to the misuse of the word 'friend' and to esteem lavished on everybody. Yet Molière would not have created the debased Manly, and Wycherley could not have conceived the spirit of Alceste. The influence of Molière is by no means confined to the title-rôle. Oronte suggests Major Oldfox in his desire for flattery of his literary merits. Célimène plays with Acaste and Clitandre as Olivia does with Novel and Plausible, and Olivia's duplicity toward them is disclosed, as in Molière, by an exchange of letters. In The Plain Dealer Wycherley comments on The Country Wife as does Molière on his own play in the Critique de L'École des Femmes. In a familiar passage in his Letters concerning the English Nation, ${ }^{2}$ Voltaire draws this comparison: 'All Wycherley's strokes are stronger and bolder than those of our Misanthrope, but then they are less delicate, and the Rules of Decorum are not so well observed in this Play.' Another possible French influence has been noticed in The Plain Dealer, the resemblance of the Widow Blackacre to the Countess

1 Compare the scenes where Philinte takes issue with Alceste, and Freeman with Manly, on their insistence upon absolute sincerity in speech. Note their identical laconic responses, e.g. 'Oui' 'Yes'; 'Sans doute' - 'No doubt on't.'

21733 edition, Létter xix, pp. 182-3. 
in Racine's Les Plaideurs (r668). Wycherley's brief experience in law may have supplied some specific touches to a portrait which has sometimes been unjustly regarded as an absolute copy of Racine.

The Plain Dealer takes its hero from Molière, its heroines from Shakespeare. Fidelia is a debased Viola - a pandar to Manly's base intrigue. Olivia's fondness for her, the very name Olivia, Fidelia's disguise, the duel thrust upon her - all clearly recall Twelfth Night. Yet, despite the fact that Wycherley not merely borrowed but defaced his borrowings, he is more than a faint echo of great originals. The skill with which he combined varied materials, the vigour, however animal, which he imparted to some of his characters, the dialogue through which they move and in which they have their being, bear witness to dramatic power. Wycherley's Olivia, though her nimbleness of wit in dissecting suitors may not vie with Portia's, gives a spirited description of coxcombry, and at times anticipates Lady Teazle and her school. Of Lady Autumn she says, 'She looks like an old coach new painted; affecting an unseemly smugness, whilst she is ready to drop in pieces'; of her daughter, 'She is still most splendidly, gallantly ugly, and looks like an ill piece of daubing in a rich frame' (II, I). In the 'Apology' that prefaced his State of Innocence, Dryden pronounced The Plain Dealer 'one of the most bold, most general, and most useful satires, which has ever been presented on the English theatre.' 1 With somewhat the same feeling, Congreve's Prologue to Love for Love (1695) declares that

1 Scott-Saintsbury edition of Dryden, V, Ir5. 
Since The Plain Dealer's scenes of manly rage Not one has dared to lash this crying age.

The boldness of Wycherley's satire need not be disputed, but the hypocrisy which he lashed was not that of vicious passion. 'Honest Manly' did well to anticipate Burns in asserting, ' $I$ weigh the man, not his title; 'tis not the king's stamp can make the metal better or heavier' (I, I). Yet Wycherley's estimate of manhood did not rest on moral integrity.

Of Wycherley's general merits as a dramatist, perhaps the most obvious is strength. 'Manly' Wycherley he was dubbed, and, however brutalized the man, and however animal the strength, there runs through his work a dominant tone of masculine virility. This strength of dramatic power expresses itself in plot, character, and comic spirit. Though his plots are generally borrowed, they are skilfully constructed and combined. The characters are distinct and often memorable - Manly, the 'Plain Dealer,' Mrs. Pinchwife, the ingenue, the Widow Blackacre, the 'pert railing Coxcomb' Novel, Sparkish, and Major Oldfox. Wycherley's defects are self-evident. His strength is perverted by harsh cynicism, bitter irony, and animalism. The passions are unmuzzled, and virtue is derided. Yet he remains a commanding figure in early Restoration comedy.

The influence of Molière upon Restoration comedy, so apparent in the work of Etherege and Wycherley, by no means brought about an essentially Gallicized English comedy. Side by side with Gallic influence was maintained the English line of tradition. Jonson, who had found an early follower in Wilson, was 
an acknowledged model to Dryden when he sought 'a mingled chime Of Jonson's humour, with Corneille's rhyme.' 1 Still more marked homage was paid to Jonson in the deliberate theory and practice of Thomas Shadwell (I642?-I692). In the Preface to The Sullen Lovers ( $\mathrm{I} 668$ ), his first comedy, Shadwell calls Jonson 'the man of all the world, I most passionately admire for his excellency in his dramatic poetry.' The Humorists ( ${ }^{6} 670$ ) bears, in its title, testimony to the declarations in its Preface. The Virtuoso (i676) has 'humour' characters like Sir Formal Trifle, the Orator, and Sir Nicholas Gimcrack, the Virtuoso, who is so fond of theoretical knowledge that he contents himself 'with the Speculative part of Swimming' by practising on a table. Shadwell, indeed, borrowed readily from Molière, as in The Sullen Lovers and The Miser ( $167 \mathrm{I}$ ), but the Preface to the latter play asserts that, "Tis not barrenness of wit or invention, that makes us borrow from the French, but laziness.' Even in this adaptation of L'Avare, Shadwell added numerous characters not in the original, and Bury Fair is indebted to the Duke of Newcastle's Triumphant Widow as well as to Les Précieuses Ridicules.

Prejudged by Dryden's 'But Shadwell never deviates into sense,' Thomas Shadwell has often failed to secure a fair hearing. Yet it would be hard to find more faithful reproduction of the details of fashionable Restoration life than in some of his comedies of manners. With the usual Restoration coarseness, Shadwell portrays vividly the external minutiæ of fashion and folly. Epsom Wells (1672) is a lively picture of

1 Prologue to Secret Love (printed I668). 
contemporary life. The characters include a pair of deceived husbands, Mrs. Jilt, who runs the gauntlet of gallantry with many stumblings, Clodpate, a stupid Country Justice, who is captured by Mrs. Jilt's crafty catering to his known aversion to London, Kick and Cuff, bullies whose function is to assault unprotected women, and Rain and Bevil, two fast Londoners, who are won to marriage, after many amours, by Lucia and Carolina. Some chance passages in the opening scene illustrate the general tone towards wine and women: 'We should no more be troubled at the Feavers we get in drinking, than the Honourable wounds we receive in Battle'; 'We live more in a week, than those insipid-temperatefools do in a year'; 'Is it not better to let life go out in a blaze than a snuff ?' 'Well, the sin's so sweet, and the temptation so strong; I have no power to resist it.'

Though his earlier plays are so far contemporary with those of Etherege and Wycherley that he shares with them some of the early distinctions in Restoration comedy, his comedies, like Dryden's, continued long after theirs had ceased. Shadwell satisfied the popular taste for opera in his version of The Tempest (1673) ${ }^{1}$ and in Psyche (1674), produced with elaborate scenery. In revising Timon of Athens ( 1678 ), the veneration for Shakespeare expressed in Shadwell's tribute did not prevent him from adding: 'Yet I can truly say, I have made it into a Play.' ${ }^{2}$ Among his

1 This should not be confused with the version by D'Avenant and Dryden, acted 1667 , printed 1670.

2 Epistle Dedicatory to The History of Timon of Athens, the ManHater, 1678 quarto. 
later plays are $A$ True Widow, The Lancashire Witches, The Squire of Alsatia (r688), in which the lively local colour of Whitefriars is emphasized with an abundance of sharpers' slang, and Bury Fair (I689), often regarded as his best comic achievement. Almost a score of pieces for the stage testify to dramatic activity which was not wholly checked either by Dryden's satire of the 'last great prophet of tautology' or by that prophet's succession to the laureateship left vacant by the satirist. It is indicative of the trend of the times that three laureates, D'Avenant, Dryden, and Shadwell, are prominently connected with the history of Restoration drama. Shadwell's own position in that drama is suggested in Rochester's dispassionate words :

Shadwell's unfinish'd Works do yet impart

Great Proofs of Force of Nature, none of Art;

With just bold Strokes he dashes here and there,

Shewing great Mastery with little Care. ${ }^{1}$

Not merely the excesses of heroic drama, but the shortcomings of Restoration comedy, were exposed in the Prologue to The Rehearsal:

Our Poets make us laugh at Tragedy,

And with their Comedies they make us cry.

Yet comedy in the early years of the Restoration finds not unworthy expression in the work of Wilson, Dryden, Etherege, Wycherley, and Shadwell. Heralded by the Jonsonian 'humour' comedy, the Restoration comedy of manners had now stepped forth to take the centre of the comic stage. Reproducing

1 The Works of . . John Earl of Rochester, 1718, p. 21. 
without reserve the license and immorality, as well as the fashions and foibles of society, it presented a brilliant picture of the London world. Superficial, almost of necessity, was the comedy that mirrored the manners of a superficial society. Yet the type of comedy already presented by earlier dramatists was to develop greatly in the work of William Congreve, and its genius, purged of offence, was to find full expression in Richard Brinsley Sheridan. 


\section{CHAPTER VI}

DRYDEN, LEE, AND OTWAY

THE record of early Restoration tragedy and comedy alike shows ceaseless conflict between English and Continental forces. When Dryden, abandoning rhyme, sought in All for Love (I678) a Shakespearean model both in verse and subject, the tide of battle seems to turn decisively. In reality, the victory of Elizabethan practice over classical theory is but partial. Dryden's very Preface shows that he serves two masters ; for, if he loves 'the divine Shakespeare,' he certainly does not hate 'the ancients, who, as Mr. Rymer has judiciously observed, are and ought to be our masters.' In Thomas Rymer (I64I-I7I3), whom Dryden thus quoted with approval, Elizabethan drama found an intolerant critic. In his Preface to an English translation of Rapin's Reflections on Aristotle's Treatise of Poesie (I674), Rymer tried to show 'how unhappy the greatest English Poets have been through their ignorance or negligence of these fundamental Rules and Laws of Aristotle.' In the very year of the production of All for Love, he concentrated his attack upon Elizabethan drama in The Tragedies of The last Age, Consider'd and Examin'd by the Practice of the Ancients, and by the Common sense of all Ages, and made an ineffective effort to translate theory into practice by 
publishing a rhymed heroic tragedy, Edgar. ${ }^{1}$ It is perhaps suggestive that, of the six plays which Rymer proposed to discuss as examples of 'the choicest and most applauded English Tragedies of this last age,' three were by Fletcher, two by Shakespeare, and one by Jonson. As the attack upon Fletcher. exhausted his limits of space, Shakespeare escaped for the nonce. But these were not passing shots of criticism. In A Short View of Tragedy; It's Original, Excellency, and Corruption. With some Reflections on Shakespear and other Practitioners for the Stage (1693), Rymer still stood by his guns. From the standpoint of 'common sense' he aimed in earnest at the license of Elizabethan romantic drama, as the light-hearted authors of The Rehearsal had done in jest at the excesses of heroic drama. 'We want,' he urged, 'a law for Acting the Rehearsal once a week, to keep us in our senses.' 2 Sense, indeed, there is beneath the nonsense of The Rehearsal, but Rymer's 'sense' leads him to the conclusion that the 'tragical part' of Othello 'is, plainly none other, than a Bloody Farce, without salt or savour.' ${ }^{3}$ There is little need to discuss here verdicts on Rymer ranging from Pope's opinion that he was 'on the whole, one of the best critics we ever had' 4 to Macaulay's brusque characterization of him as the worst critic that ever lived. What is significant is that Rymer was a prophet

1 Many of Rymer's couplets seem to indicate either extraordinary perversities of rhyme or lapses into blank verse.

2 A Short View of Tragedy, p. 158.

Ibid., p. 146.

Spence, Anecdotes, Malone edition, 1820, p. 85. 
not without honour in his own day and in later generations that felt the classical impulse. The passing of rhymed heroic drama may have urged the swing of the pendulum toward Elizabethan dramatic models, but the weight of classical authority retarded the motion.

The Preface to All for Love shows Dryden's own indecision. Though he shakes off the fetters of rhyme under which the Prologue to Aureng-Zebe had shown him to be restless, the verdict against rhyme is qualified: 'In my style, I have professed to imitate the divine Shakespeare; which that I might perform more freely, I have disencumbered myself from rhyme. Not that I condemn my former way, but that this is more proper to my present purpose.' He admits, with Rymer, that the ancients 'are and ought to be our masters. ... Yet, though their models are regular, they are too little for English tragedy; which requires to be built in a larger compass.' But the old fear that the Elizabethan compass was too large seems to linger: "The fabric of the play is regular enough, as to the inferior parts of it; and the unities of time, place, and action, more exactly observed, than perhaps the English theatre requires. Particularly, the action is so much one, that it is the only of the kind without episode, or underplot; every scene in the tragedy conducing to the main design, and every act concluding with a turn of it.' In contrast with the romantic freedom of Antony and Cleopatra, All for Love shows classical restraint. Dryden compresses time and action, and confines the scene to Alexandria; Shakespeare sweeps 
in action over a dozen years and in scene over seas and continents. Equally marked is the contrast between Dryden's simplicity and Shakespeare's multiplicity in number of dramatis personce and of separate scenes. Dryden's deference to classic theories results happily for him in an avoidance of some direct comparisons with Shakespeare which might have been fatal. He could not hope to rival the imperial sweep and infinite variety of Shakespeare's world tragedy, but the classical limitations brought a gain in unity and concentration of action.

Sound sense and becoming modesty are not wanting in Dryden's estimate of his own drama. 'Since I must not be over-confident of my own performance after him [Shakespeare], it will be prudence in me to be silent. Yet, I hope, I may affirm, and without vanity, that by imitating him, I have excelled myself throughout the play; and particularly, that I prefer the scene betwixt Antony and Ventidius in the first act, to anything which I have written in this kind.' Dryden's hopes have been realized and his judgment usually confirmed. The only play which he wrote to please himself pleased both his contemporaries and the audiences of the next century, and has found high favour with modern critics. Though admittedly inferior to Antony and Cleopatra, All for Love may fairly be said to be worthy of its great theme. Dryden's Cleopatra cannot stand with one of whom her greatest critic wrote, 'Age cannot wither her, Nor custom stale her infinite variety.' Yet, in his verse, Dryden touched perhaps the height of poetic tragedy 
of his age. Save Milton's, ${ }^{1}$ Restoration blank verse had but rarely triumphed. But Antony's words over Ventidius have almost the Shakespearean note, and many passages in the drama not merely arrest attention, but charm the fancy.

In the actual manipulation of the plot there are marked differences between All for Love and Antony and Cleopatra. Shakespeare keeps Octavia and Cleopatra apart; Dryden, paying toll perhaps to the unity of place, brings them together in what Scott calls a 'scolding scene.' Shakespeare's Antony really mourns the loss of his first wife, and accepts Octavia with good intentions. Shakespeare introduces the defection and final repentance of Enobarbus, and the scene of the drunken carousal on Pompey's galley, but has only a hint of the Dolabella-Cleopatra episode which Dryden makes prominent. It is noteworthy that perhaps the highest achievement of Restoration tragedy, with the possible exception of Otway's Venice Preserved, turns not to French masters, but to the greatest English dramatist. Yet the reversion toward an Elizabethan model is somewhat checked by the restraint of classical convention.

In the same year with All for Love (1678), Dryden produced a coarse comedy, Limberham, or The Kind Keeper, and, in conjunction with Nathaniel Lee, CEdipus, a tragedy of which the theme is classical, but in which the introduction of incantations and

${ }^{1}$ Samson Agonistes (167I), which Milton's preface declares 'never was intended' for the stage, and which accordingly omitted 'division into act and scene,' belongs to poetical rather than to dramatic literature. 
ghosts (Act III) seems Elizabethan. With Lee he again collaborated in The Duke of Guise (1682). To Troilus and Cressida (1679), an alteration from Shakespeare, Dryden prefixed his important essay on The Grounds of Criticism in Tragedy, in which he extols the genius of characterization in Shakespeare and Fletcher, a 'limb of Shakespeare,' but cites with approval Rymer's strictures on their plots, and advocates strongly the classical unity of action. The Spanish Friar, or The Double Discovery (I68I), a tragi-comedy, reveals more comic force than was usual with Dryden, and suggests that his own confession that he was 'not so fitted by nature to write comedy' ${ }^{1}$ as more serious drama has perhaps been accepted too readily as sufficient proof of his mediocrity in comedy. In Scott's opinion, Dryden's dramatic masterpiece is Don Sebastian (1690), a tragedy in blank verse and prose. Its length and the poverty of its comic parts hardly justify this superlative, but the characters of Sebastian and Dorax are strongly drawn and their clash results in a powerful dramatic scene $(\mathrm{IV}, 3)$. In the same year appeared $A m p h i$ tryon, in which Dryden follows Plautus and Molière, but with real individuality of treatment, and with a vigour coarse, but undeniable. In Cleomenes (1692), he took a Spartan hero from Plutarch and fashioned a tragedy that suggests the general influence of French classical tendencies, though perhaps, as Scott conceived, with some specific obligation to Fletcher's Bonduca. An unsuccessful tragi-comedy, Love Triumphant ( 1694 ) has little interest apart from the fact

${ }^{1}$ A Defence of an Essay of Dramatic Poesy, Essays, Ker, I, I16. 
that, like Cleomenes, it sometimes employs rhymed couplets.

Dryden's operas deserve some mention, not from their intrinsic merits, but from their bearings on the development of English opera. Albion and Albanius (I685), with music by the French bandmaster of Charles II, shows the growing influence of French opera at a time when Locke and Purcell had already given attention to operatic productions. Saint-Évremond, who professed himself 'no great Admirer of Comedies in Musick,' 1 confessed some interest in their 'magnificence,' their surprising 'machines,' and their sometimes 'charming' music, but found them, on the whole, 'very tedious.' To the modern reader, Albion and Albanius, and its sequel, King Arthur, or The British Worthy (I69I) seem to confirm Saint-Evvremond's caustic definition of opera as 'An odd Medley of Poetry and Musick, wherein the Poet and the Musician, equally confined one by the other, take a world of Pains to compose a wretched Performance.' Dryden's operas, however, help to confirm the variety of his dramatic product and to illustrate the influence of French opera upon the later Restoration stage.

In the history of Restoration drama, Dryden holds the centre of the scene. The foremost of the heroic dramatists, he formulated the rules of the school, produced its chief examples, and by abandoning rhyme sealed its fate. In the return to blank verse and the partial recurrence to other Elizabethan dramatic standards, he is again the commanding figure. As he matured, his critical judgments changed decidedly.

${ }^{1}$ Works of Monsieur de St. Evremond, I714, II, 85-87. 
His appreciation of Shakespeare, at first checked by the conventional attitude of his day to the 'barbarous age' of Elizabeth, finally outgrew artificial restraint. The larger charity of old age led him to accept in the main the strictures which Jeremy Collier passed upon the looseness of his earlier dramatic work. ${ }^{1}$ His death closed the century. Already the old order was changing, as the tide of moral regeneration rose steadily. Of the many parts which Dryden played in the history of English literature the greatest was not in drama. Yet he remains, despite his limitations, the most imposing figure in Restoration dramatic history.

It has been convenient to regard the year 1678 as the end of the period of rhymed heroic drama and to consider, though with some qualifications, All for Love as in some sense a point of departure for the restoration of blank verse and other Elizabethan tendencies. One evidence of the growth of Elizabethan influence is the decided increase thereafter in Restoration adaptations of Shakespeare. More significant, however, in the increasing dominance of Elizabethan forces is the advent of two powerful tragic dramatists who belong essentially to the new period of blankverse tragedy. Among the heroic dramatists Dryden towered almost solitary. In blank-verse tragedy, Nathaniel Lee and Thomas Otway rose to heights that fairly challenged comparison. Through the tawdry bombast of Lee's verse break many gleams of true poetry, and in Venice Preserved Otway equalled, if he did not surpass, Dryden's highest dramatic achievement.

${ }^{1}$ Dryden, Preface to the Fables, Ker, II, 272. 
Widely separated in many ways as tragic dramatists, Nathaniel Lee ( 1653 ? $-\mathrm{I} 692$ ) and Thomas Otway (1652-I685), were close contemporaries. Their early lives had much in common. Both were sons of clergymen, attended one of the great universities, failed as actors, and turned to playwriting. Both produced their first plays in I $_{75}$, and both used rhyme, wholly or chiefly, in their first three tragedies. This fact is but another warning against attempts to establish inelastic divisions between literary periods and to make individual dramatists conform to arbitrary classification. Schooled in rhyme, they outgrew early habit, and Lee anticipated Dryden in the actual adoption of blank verse.

In Nero (I675), Sophonisba, or Hannibal's Overthrow (1676), and Gloriana, or The Court of Augustus Casar (1676), Lee wrote tragedy, chiefly in rhyme, with semi-historical themes and the foreign setting usual in heroic drama. His great dramatic success The Rival Queens, or The Death of Alexander the Great (1677) anticipated All for Love in the use of blank verse. Like Gloriana, it is indebted to one of La Calprenède's romances. The main theme of this famous play is the jealousy between Roxana, Alexander's first wife, and his second wife, Statira. In the parts of the rival queens, actresses vied with each other on the English boards for a century and a half. Most of Lee's theatrical effectiveness is lost to the reader. Yet it is by no means wholly modern criticism that has fastened upon the rant and extravagance of the play for familiar illustration of the excesses of tragedy of the period. 'In what Raptures,' wrote Colley 
Cibber,' 'have I seen an Audience at the furious Fustian and turgid Rants in Nat. Lee's Alexander the Great! For though I can allow this Play a few great Beauties, yet it is not without its extravagant Blemishes.' Furthermore, Cibber thought it a greater proof of Betterton's skill that he succeeded in 'the false Fire and Extravagancies' of Alexander than that he triumphed in any of the Shakespearean rôles. The extravagance is, certainly, apparent. A good example is the absurd account (Act IV) of how Lysimachus does battle with a lion, pulls out his tongue, bestrides, and kills him - a feat which moves Alexander to pardon the 'active Prince' more than 'all the Prayers Of the lamenting Queens.' In the last scene, Alexander, maddened by poison, mounts a chair, shouting, 'Bear me, Bucephalus, amongst the billows.' Amid the obvious extravagances of the play, however, its merits have sometimes been undervalued. Not all the talk is bombast. Many lines are in familiar quotation: "Tis Beauty calls, and Glory shews the way;' 'When Greeks joyn'd Greeks, then was the tug of War.' 2 The attack of Clytus upon Alexander's arrogance at the banquet (Act IV) is fervent and effective. There is real as well as 'false fire,' and force instead of farce.

Mithridates (1678) is in marked contrast to Racine's earlier play on the same subject. Racine is simpler

1 Colley Cibber's $A$ pology, Lowe edition, I, ro5.

2 Both lines occur in Act IV. See 1677 quarto, pp. 53, 48. The lines beginning 'See the conquering hero comes' are not Lee's, but were written by Doctor Morell for a Handel oratorio, and were later interpolated in Lee's play, in Act II 
in plot, nobler in characterization, and without the sensational intrigues and accumulated horrors which Lee lavished upon his play. The appearance, in the fourth act, of the ghosts of Mithridates's sons, who 'set Daggers to his Breast and vanish,' and the use of spectacular devices point not across the Channel to French drama, but backwards to the Elizabethans. Theodosius, or the Force of Love (1680) deals with the rivalries of brothers in love. Casar Borgia (I680) proceeds to its grim conclusion with the strangling of the heroine on the stage, and with the poisoning of the rest of the chief characters. By the irony of fate Machiavelli, the villain, is left to pronounce a moral which is singularly inappropriate in his mouth :

No Power is safe, nor no Religion good,

Whose Principles of Growth are laid in Blood.

Lucius Junius Brutus, Father of his Country (168r), met its end on the third night, when it was suppressed on account of supposed allusions to the vices of Charles II. All these dramas are essentially blank-verse tragedies, though Theodosius freely admits rhyme. The Princess of Cleve (I68I) is described in the dedication as 'this Farce, Comedy, Tragedy, or meer Play.' 'Mere play' seems hardly epithet sufficient for this coarse offspring of Madame de La Fayette's French romance. Constantine the Great (1684) and The Massacre of Paris ( 1690 ) revert to blank-verse tragedy.

Despite the rant and fustian associated with Lee's name, there is something more than bombast in his extravagance. He is one of the few dramatists of the 
last half of the seventeenth century who had the poetic touch. The insanity brought on by his dissolute life pervades some of his stage characters. His poet's eye in a fine frenzy rolled, though often there is frenzy without poetry. In the midst of a prosaic age, it is a surprise to find embedded in conventional tragedy passages which reveal poetic imagination, such as that often quoted from the last act of $C$ Edipus:

Thou, Coward, yet

Art living, canst not, wilt not, find the Road

To the great Palace of magnificent Death;

Tho' thousand ways lead to his thousand doors,

Which day and night are still unbarr'd for all.

Lee had, to take a phrase from one of his dedications, ${ }^{1}$ an 'ungoverned fancy.' Force and weakness, pathos and bathos, poetry and rant, mingle in his uneven pages. The impure element of insanity in his blood overran into his work. In him lived the promise of poetry, but the 'magnificent death' which his genius conceived brought him to a dissolute's grave. Lee touched the heights, but sank into the depths.

The dramatic work of Thомаs OTway (1652-1685) began with Alcibiades (1675), a conventional rhymed tragedy. Don Carlos ( 1676$)$, based on a theme from a French historical romance, shows genuine dramatic ability. It won marked favour in its own day, and Gosse thinks 'we should be justified in calling Don Carlos the best English tragedy in rhyme.' ${ }^{2}$ The comparative poverty of English rhymed plays, it

1 Epistle Dedicatory to Theodosius.

2 Seventeenth-Century Studies, p. 279. 
should be remembered, tempers praise which may sound superlative. Titus and Berenice (I677), a good version of Racine's Bérénice, and The Cheats of Scapin (1677), a version of Molière's Les Fourberies de Scapin, were followed by two dull comedies, Friendship in Fashion ( 1678 ), and The Soldier's Fortune (I68I, or earlier), ${ }^{1}$ the latter containing perhaps some personal touches drawn from the author's brief military service in Flanders. The History and Fall of Caius Marius (I680), a version of Romeo and Juliet, roughly accentuates the element of comedy, but aggravates also the tragic conclusion by allowing Lavinia to awake in the tomb before the death of her Marius.

Otway's real fame rests on his last two tragedies. Following the fashion of Lee and Dryden, he now adopted blank verse. In The Orphan (I680), Castalio and Polydore, twin sons of Acasto, fall in love with Monimia, an orphan under Acasto's guardianship. Polydore, ignorant of Castalio's secret marriage to Monimia, overhears their plan for what he believes is a guilty assignation, and under cover of night keeps his brother's appointment. The discovery of the marriage leads Polydore to provoke a quarrel in which he allows his brother to stab him. Castalio, on learning the truth, commits suicide, and Monimia takes poison. The action gains in simplicity and intensity by being centred in three main characters. Usually the action is rapid, though Castalio indulges in some descriptive passages, and Acasto in some talk against court flattery and hypocrisy. The plot turns upon an act of brutality, but the pathos of the

'A 'Second Part,' entitled The Atheist, was produced in 1684. 
conclusion is indisputable. The power of the tragedy lies rather in cumulative force than in detached passages of verse. As Monimia, Mrs. Barry won a great stage triumph, and even in the reading of the drama the improbability on which the plot rests is largely forgotten in the pathos of the last acts. Grief is portrayed with almost feminine tenderness. Otway points back to Elizabethan tragedy. Even his diction seems reminiscent of Shakespeare. ${ }^{1}$ The Orphan may, possibly, be termed the first domestic tragedy since Elizabethan drama. The royal personages and impossible heroes of heroic drama are banished from the boards. Rank is forgotten in the poignancy of human woe. In an artificial age, Otway awakens Elizabethan echoes.

Venice Preserved, or a Plot Discovered (1682), is one of the greatest tragedies of modern English drama. In its own age possibly only Dryden's All for Love can sustain the comparison with it, and it touches, in the fourth act, perhaps the highest mark of Restoration tragedy. The main subject, drawn from the Abbé de St. Réal's account of a Venetian conspiracy in 1618 , is unhappily yoked to a subordinate theme which reflects English politics. The doting buffoon, Antonio, is Shaftesbury caricatured. His age, sixty-one, his garrulity of speech, his desire to be elected King of Poland, are mocked in Prologue and in the play. The comic scenes detract greatly from the merits of the tragedy, yet Taine curiously found them worthy

1 The description of the witch (II, r) recalls Shakespeare's method in descriptions like that of the 'I do remember an apothecary' speech in Romeo and Juliet. 
of praise. ${ }^{1}$ A rough parallel may be suggested in the comic scenes of Marlowe's Dr. Faustus, though it should be said that modern stage revivals of $D r$. Faustus have done much to prove that even these comic passages may be made fairly effective. The setting of the play, with perhaps an opening hint of Othello, is picturesque. The action, save for the intrusion of the comic scenes, advances rapidly, and towards the end almost breathlessly. Passion not merely is sustained but rises to greater heights. As in The Orphan, three characters dominate the action. Pierre, a sort of Brutus with the high Roman courage, leads Jaffeir to join the conspiracy against Venice. Belvidera, Jaffeir's wife, persuades her husband to save her father and the Senate by revealing the plot. The action unfolds in masterly scenes which turn the familiar heroic conflicts between love and honour into poignant tragedy. The conflict ends at the scaffold where, at Pierre's entreaty, Jaffeir stabs him to the heart, and then turns the dagger upon himself. The apparition of the ghosts of Jaffeir and Pierre and Belvidera's madness and death strongly suggest the Elizabethans, but it is by intrinsic merit that Venice Preserved best maintains the English dramatic tradition.

The secret of Otway's success is truth to nature. The irresolute Jaffeir, standing midway between the tender Belvidera and the iron Pierre, is the centre of dramatic conflict. Rant, bombast, and exaggeration - the fundamentals of heroic drama - give way to human emotion. Pathos does not sink into bathos,

${ }^{1}$ History of English Literature, Edinburgh, 1873-4 edition, III, $39-41$. 
and if Otway's tragedies end in blood, it is wrung from the human heart. The almost classical unity of action in Otway's two masterpieces results less from a following of rules than from a natural impulse to centre the attention on the chief characters. It is a simplicity which recalls Hawthorne's handling in the novel of a few great characters. The phrasing is terse and lucid; the plot sweeps forward with resistless force.

It is easy to find Otway's limitations and positive faults. To evident poverty of comic genius must be added lack of high lyrical poetry. The imagination does not soar with the Elizabethan gift of song. Nor does the breadth of his character conceptions equal their depth. Don Carlos, Castalio, and Jaffeir are cast in one mould. Infatuated with woman's love they stand irresolute. The Queen in Don Carlos, Monimia, and Belvidera are alike tender, sensitive heroines, with the feminine appeal to the sensibilities. Otway could not run the whole gamut of human emotion, but he touched a few notes with the certainty of a master hand. If his tragedies do not inspire awe, they touch the gentler spring of pity. Sincerity, naturalness, and artistic restraint - qualities rarer than ever in Restoration tragedy - are the foundation of Otway's dramatic genius. 


\section{CHAPTER VII}

\section{ASPECTS OF MINOR RESTORATION DRAMA}

THE main currents of Restoration drama have thus far been noted chiefly in the work of its leading writers. Yet it is wholly unsafe to disregard the lesser and sometimes contrary currents of minor drama. The sea of dramatic forces cannot, in any case, be charted with entire precision, but it is especially dangerous to base calculations simply upon the major turns of the tide. The convenient grouping of the comedies of Etherege, Wycherley, and Shadwell, in distinction from the tragedies of Dryden, Lee, and Otway, should not lead to the facile assumption that Restoration drama can arbitrarily be separated into distinct schools of comedy and tragedy. With the exception of Dryden, the leading dramatists seem, perhaps, to conform roughly to such classification. Yet Etherege's comedy shows, at least in one instance, the influence of heroic drama; heroic tragedy often adopts a happy issue out of its afflictions, and tragi-comedy violates the classical distinctions between comedy and tragedy. Even disregarding opera, with its complex and varying relations to heroic drama, to comedy, and to the masque, the more regular drama often oversteps precise limits. Especially should the irregularities and inconsistencies of many minor dramatists be a warning against rigid lines of division. During the 
height of rhymed heroic tragedy, Crowne wrote a tragi-comedy largely in blank verse, and, long after the general adoption of blank verse, he reverted to rhymed heroic tragedy. Howard, though advocating blank verse in his dispute with Dryden, used rhyme to a considerable extent. Even brief study of the lesser products of Restoration drama will show that convenient generalizations must not be mistaken for fixed laws governing dramatic development.

The terms 'major' and 'minor' are here applied to Restoration drama primarily for convenience. The objection already urged against rigid separation of tragic and comic dramas would apply with at least equal force to arbitrary distinctions between dramatists whose importance varies greatly according to the critic's point of view. D'Avenant, for example, has historical significance wholly out of proportion with his literary achievement. Shadwell, whose comedies it has been convenient to discuss in connection with those of Etherege and Wycherley, might well be classed with lesser dramatists. With no intention, then, to insist dogmatically on precise classification of individual playwrights, and with no desire to essay the impossible task of presenting an allinclusive estimate of the dramatic output of the period, attention will be directed in this chapter to some aspects of that mass of dramatic writings which, in the main, gave bulk rather than distinction to Restoration drama. So continuous is this dramatic output, that it is difficult to set even a general chronological limit to the plays that might here be considered. Roughly speaking, however, the Revolu- 
tion of 1688 may be adopted as a more or less elastic limit. If only the more prominent dramatists were to be included, there would be little difficulty in adopting definitely the division suggested by Edmund Gosse. ${ }^{1}$ He distinguishes clearly between the earlier group of dramatists, such as Crowne, Mrs. Behn, Wycherley, Lacy, Settle, Otway, and Lee, for whom he reserves the name of Restoration dramatists, and a later group, including Congreve, Cibber, Vanbrugh, Farquhar, and Rowe, whom he entitles the 'Orange dramatists.' It is true, indeed, as he points out, that the later writers are not connected with the reign of Charles II, but this is no more insuperable obstacle to their inclusion as 'Restoration dramatists' than is the death of Queen Elizabeth to the frequent extension of the term 'Elizabethan' to the later work of Shakespeare and his successors. Thus Leigh Hunt was warranted in grouping, in his well-known edition, the comedies of Wycherley, Congreve, Vanbrugh, and Farquhar, for not even the end of the seventeenth century marks the full conclusion of the dramatic period ushered in by the Restoration. Furthermore, the apparent gap between the two groups of major dramatists is somewhat bridged by the work of minor playwrights. $^{2}$ In the last analysis, the division lines between dramatic periods and the nomenclature adopted must remain largely arbitrary, a matter of

\section{${ }^{1}$ Seventeenth-Century Studies, pp. 270-271.}

${ }^{2}$ Mr. Gosse's statement that, after the advent of the dramatists whose first plays fall between 1670 and 1675 , 'twenty years passed quietly on without a single new writer, except Southerne,' seems to neglect so popular a dramatist as John Banks. 
personal preference rather than for conclusive argument. In this work, the term 'Restoration drama' will include both of Mr. Gosse's groups, but the present chapter will in the main discuss playwrights the bulk of whose work precedes the Revolution of 1688 .

The widely divergent plays that may be grouped under the head of pastorals illustrate the difficulties of applying to minor Restoration drama absolute distinctions between comedy and tragedy. The very disagreements as to the acceptance of particular plays as pastorals are an index of their complex dramatic elements. For the most part these plays have kinship with heroic drama and romance, with comedy, and sometimes with rough farce, and with the masque. Their nondescript character is evident from the fact that one of the first three items in a suggestive list of Restoration pastorals ${ }^{1}$ is described on the title-page as 'A Comical History,' and the others as 'tragi-comedies,' while Crowne's Calisto (1675) is 'The Late Masque at Court.' The Thracian Wonder, though printed in $\mathrm{r} 66 \mathrm{I}$, belongs, as its usual ascription to Webster and Rowley would imply, to an earlier dramatic period. Yet its publication so soon after the reopening of the theatres is another link between Elizabethan and Restoration drama. Not even the interregnum had broken the dramatic chain, for pastorals like Richard Flecknoe's Love's Dominion (printed 1654) and Robert Cox's Actaeon and Diana (printed 1656) had found publishers. Tasso's Aminta and Guarini's Pastor Fido, two classic Italian pastorals already influential through Elizabethan translations,

${ }^{1}$ Jeannette Marks, English Pastoral Drama, pp. 179-180. 
appeared in Restoration versions. ${ }^{1}$ The lyric impulse of the Elizabethans had, indeed, passed, and the charm of naturalness had been lost in an artificial age. Simplicity and spontaneity, so necessary to redeem the pastoral from conventionality, were missing in Restoration days, but the earlier tradition had not been wholly forgotten. Restoration dramatic pastorals usually exhibit a blend of comic, tragic, and musical elements. The Thracian Wonder, which bears marked resemblance to The Winter's Tale, includes some rustic scenes and shepherds' dances, mingles verse with prose, and has heroic as well as pastoral elements. Thomas Killigrew's two-part Bellamira introduces an 'Arcadian Nymph' who dwells in a cave with her brother, and a King and Prince who battle with Spaniards as well as invade Arcadia. Shadwell, who fashioned The Royal Shepherdess (I669) from the material of 'one Mr. Fountain of Devonshire . . . endeavour'd to carry on those few Humors, which were but begun by him ; and (to satisfie the Concupiscence, as Mr. Johnson calls it, of Jigge and Song) I designed as fit occasions for them as I could.' Crowne's Calisto, with songs and music that link the masque with opera, has pastoral elements in its nymphs and shepherds. The Constant Nymph, or The Rambling Shepheard (1677), 'written by a Person of Quality,' borrows from Sidney's Arcadia, and largely uses the heroic couplet instead of the blank verse of tragedy or the prose of comedy. At almost every turn may be noted divergencies in subject, treatment, and

${ }^{1}$ Dancer's translation of the former in 1660 , Settle's rendering of the latter in 1677 . 
versification from what may be regarded as the normal standard, but cannot possibly be accepted as the fixed practice, of Restoration drama. Dull, monotonous, vulgar, and tawdry, the Restoration pastoral usually is. It holds, doubtless, the least honoured position in the dramatic record of the time, yet some interest attaches to it as proof of the continuity of Elizabethan dramatic influences and of the complexity of dramatic development during the Restoration.

The dramatic pastoral may perhaps be regarded as a by-product of Restoration drama. Attention should now be directed to more regular tragic and comic products of minor Restoration drama. Often these lesser plays afford further illustration of practices and tendencies apparent in the work of leading dramatists. Here, for example, may be multiplied the proofs of Continental influences upon Restoration drama, yet here again is disproof of the theory that English drama became denationalized. The use of Spanish material, already observed in early comedies of Dryden and Wycherley, in Digby's adaptations from Calderon, and in Tuke's Adventures of Five Hours (1663), is continued in Crowne's Sir Courtly Nice (1685), taken from Moreto, and in various plays of Mrs. Aphra Behn, such as The Dutch Lover (1673) and The Rover (1677), said to reflect, in part, Spanish influences. The French romances of $\mathrm{La}$ Calprenède and Madeleine de Scudéry, which contributed to the work of Dryden and Lee, supplied material for Lord Orrery, Settle, Mrs. Behn, and John Banks. Translations, adaptations, and borrow- 
ings of varying importance from French drama constantly appear in minor Restoration drama, as, for example, in the work of Charles Cotton, John Dancer, Mrs. Catharine Philips - the 'matchless Orinda' - Sir Charles Sedley, Ravenscroft, and Crowne. Despite manifest and frequent debts to foreign sources, however, the lesser as well as the greater Restoration dramatists abundantly disprove the assumption that English drama became an essentially foreign product. Plots, names, and phrases were freely appropriated from Gallic drama, but external imitation did not bring reproduction of the spirit and genius of French drama. To the influence of Corneille was added that of Jean Racine (I639-I699). In the decade following his first signal success in Andromaque (I667), Racine so far perfected French classical drama that English playwrights began to imitate the new master of tragedy. Yet his subtle analysis of character, his strength of dramatic conception, and his noble diction seem almost travestied in the conscious heroics and bombast of English heroic drama. The humanity of Molière is forgotten in the heartless immorality of Restoration comedy. Again and again do the lesser dramatic pieces of the English stage follow the letter of Gallic example, not the spirit.

Consideration of the work of a few individual dramatists will effectually disprove any theory of rigid separation between comic and tragic writers. SIR ROBERT Howard (I626-I698), who collaborated with Dryden in The Indian Queen, wrote both tragedies and comedies. His most successful comedy, 
The Committee (1662), ${ }^{1}$ satirizes the underhanded methods of committees of sequestration of property in the later Commonwealth period. Teague, an early Irish comic character, if deficient in dialect, has Irish wit enough to 'take the Covenant' by stealing a copy of it from a bookseller. The Great Favourite, or The Duke of Lerma (I668), a tragedy, has 'some Scenes in blank Verse, others in Rhime,' despite Howard's protest against Dryden's theory of rhyme. The Epilogue tersely describes it as 'A melancholly Plot ty'd with strong Lines.' Sir Charles Sedley (I639?I70I), whose rhymed heroic tragedy, Antony and Cleopatra (1677), was, in Shadwell's ill-founded judgment, the 'only' tragedy '(except two of Jonson's and one of Shakespear's) wherein Romans are made to speak and do like Romans,' ${ }^{2}$ produced three comedies. In The Mulberry Garden (r668), partly based on Molière, Sedley mingles prose with heroic couplets somewhat as did Etherege in The Comical Revenge. Bellamira, or The Mistress (1687), based on the Eunuchus of Terence, is a gross, but vigorous, satirical comedy. ${ }^{3}$ EDWARd RAVENSCROFT (fl. 1671I697) whose assiduous efforts were largely devoted to unscrupulous reworking of old veins of comic ore, also adapted Titus Andronicus, and produced a tragi-comedy and a tragedy. His theatrical successes

1 The date of its production has often been confused with that of its publication, r665. But Evelyn witnessed it 27 November, 1662, and Pepys, 12 June, 1663.

2 Epistle Dedicatory to A True Widow, 1679 quarto.

The Grumbler was not printed until 1702 . It was acted in 1754 as a farce. 
were largely due to bold pilferings from Molière, and to the farcical abandon of such a piece as his London Cuckolds (1682).

JoHN CROwne (d. I703 ?) began a prolific dramatic career with a tragi-comedy, Juliana, or The Princess of Poland ( $167 \mathrm{I})$, chiefly in blank verse, turned in the next year to rhymed historical tragedy, and in 1675 produced Andromache, a prose adaptation of Racine, The Country Wit, a comedy partly drawn from Molière, and Calisto, a court masque. Among his plays during the next decade are a heavy two-part heroic drama, The Destruction of Jerusalem, several blank-verse tragedies, and a satirical comedy, City Politiques. Sir Courtly Nice, or It cannot Be (1685) marks the height of his dramatic achievement. The titular hero, though reproducing the type of fop already evident in Etherege, may be regarded as Crowne's best contribution to the gallery of Restoration comedy portraits. Crowne's later dramatic work shows some tendency to revert to earlier dramatic influences, for The Married Beau (1694) is a blank-verse comedy which, in Dr. Ward's judgment, 'may be regarded as an attempt to return to the style of Fletcher and Shirley,' ${ }^{1}$ and Caligula (1698) is a tragedy in rhyme. Some of Crowne's indifferent tragedies seem to have achieved their success largely through scenic aids, while his comedies are without subtlety of characterization, yet 'little starch Johnny Crowne' achieved a respectable measure of stage success. To the modern reader he may serve as an illustration of the blend of dramatic types and styles in the work of a single playwright. His dramatic

1 Ward, III, 407. 
reputation must rest almost wholly upon the creation of a single character, Sir Courtly Nice.

While many of the lesser dramatists, with more or less impartiality, divided their efforts between tragedy and comedy, with not infrequent departures into tragi-comedy, opera, or masque, there are those whose names are primarily associated with a single dramatic type. JoHN LACY (d. I68r), comedian, besides adapting comedies of Molière and Shakespeare, made original excursions into the field of comedy. The rough realism of The Old Troop, or Monsieur Raggou ( 1664 ?), his best dramatic effort, doubtless owed somewhat to Lacy's own military experience during the Civil War. Elkanah Setrle (I648-I 724), on the other hand, takes hisplace with the heroic dramatists. Beginning tragedy literally in 'Cambyses' vein' with his youthful Cambyses, King of Persia, he achieved a spectacular success in The Empress of Morocco (I67 I ?), ${ }^{1}$ which led to a pamphlet controversy against the combined attacks of Crowne, Dryden, and Shadwell. Ibrahim, the Illustrious Bassa (1676), based on Georges de Scudéry's play from his sister's romance, sufficiently answers the rhetorical question of its Epilogue as to the deadly efficacy of heroic love :

What need of Siege and Conquest in a Play, When Love can do the work as well as they?

To the 'Doeg' of Dryden's satire still attaches the unsparing epithet 'heroically mad.'

1 The first edition, 1673, contains valuable drawings which show the attention paid to scenic effects. 
Upon the unlucky head of Mrs. APHRA BEHN (I640r689) have been visited many of the sins which she shared in common with her contemporaries. "The chaste Aphra' does, assuredly, justify by her works her reputation for immorality. Yet perhaps something should be forgiven a writer who produced in Oroonoko a humanitarian novel, and who revealed beneath her licentiousness in drama some evidences of lively ingenuity. Before turning to playwriting she had an adventurous career. A barber's daughter, who had spent her youth at Surinam, she returned to England shortly before the Restoration, married a Dutch merchant who brought her into some notice at the court of Charles II, and after his death served as a spy at Antwerp, was shipwrecked, and finally returned to London, where she supported herself as a writer. Her dramatic career began in $167 \mathrm{I}$ with the production of a tragi-comedy, The Forc'd Marriage, and a coarse comedy, The Amorous Prince. A single tragedy, Abdelazar, two later tragi-comedies, and a farce entitled Emperor of the Moon (I687), are less characteristic than the dozen or more comedies from her prolific pen. Of these, perhaps the best examples are The Rover, or The Banished Cavaliers (1677; Second Part, r68I) and The Roundheads (1682), which reëcho the militant notes of the Civil War, and The City Heiress (1682). With the unscrupulousness of her friend Ravenscroft, though with more than his ability, Mrs. Behn appropriated dramatic materials wherever she found them - in Killigrew, Brome, Middleton, Tatham, or Molière. With no more hesitation she stooped to conquer by 
pandaring to the coarsest taste. Yet her best comedies have vivacity of action as well as depravity of speech, and some touches of lively, though habitually gross, humour.

Nahum Tate (1652-I715) merits perhaps less attention as a dramatist than as a poet. His continuation of Dryden's Absalom and Achitophel in a second part is directly indebted to Dryden for its most notable passages, and his metrical version of the Psalms was effected in collaboration with Nicholas Brady, but Shadwell's successor to the poet laureateship holds some place among the minor poets of his day. Tate had not an independent or original mind. He was most at home in collaboration with other writers, or in imitation of their work. His dramatic efforts were largely concerned with adaptations from Shakespeare, Chapman, Fletcher, and Webster. In 168 I and 1682 he produced adaptations of Richard II, Coriolanus, and King Lear, eliminating the fool, and allowing Cordelia to marry Edgar. Despite Addison's early protest in The Spectator (No. 40), this perversion of Lear continued to hold the stage until almost the middle of the nineteenth century. Such adaptations, not merely of Shakespeare, but of other Elizabethans, emphasize at least the continued attention paid by Restoration playwrights to earlier English drama.

To the playwrights already mentioned might readily be added a host of mediocrities. The Duke of Newcastle, loyally pronounced by his Duchess, who shared his dramatic activities, 'the best lyric and 
dramatic poet of his age,' ${ }^{1}$ Sir Robert Stapylton, ${ }^{2}$ and many others show that the dramatic contagion touched rank and title. Edward and James Howard, and 'sing-song' Thomas D'Urfey are perhaps sufficient examples of the prolix mediocrity of writers who lacked even the distinction of title. Sufficient illustration, however, has already been found in minor Restoration drama of the continuity of English dramatic traditions, even during the height of Continental influences, of the constant inter-relation between different types of dramatic writing, and of the union in the work of individual dramatists of both comic and tragic impulses.

Brief mention may be accorded to some matters which, though primarily connected with theatrical history, are not without direct bearing upon the drama itself. The development of scenic and musical elements, already noted at some length in connection with the rise of heroic drama and the opera, had increasing influence. The Prologue to Tunbridge-Wells ( 1678 ) declares that

every Scribler sends his Envoys out

To fetch from Paris, Venice, or from Rome,

Fantastick fopperies to please at home.

And that each act may rise to your desire,

Devils and Witches must each Scene inspire.

Wit rowls in Waves, and showers down in Fire.

With what strange Ease a Play may now be writ,

When the best half's compos'd by painting it?

And that in th' Ayr, or Dance lyes all the Wit ?

1 Ward, III, 332, footnote 3.

2 Stapylton's plays are The Slighted Maid (1663), a comedy, The Step-Mother (1664), a tragi-comedy, and Hero and Leander (1669), a tragedy. 
Dorset Gardens Theatre, opened in 1671, devoted itself so frankly to elaborate scenic effects that Dryden found occasion to allude to 'the gaudy house with scenes.' ${ }^{\prime}$ Colley Cibber, in his account of the Patent Theatres, says that Sir William D'Avenant, to offset the success of the King's Company, 'was forced ... to introduce a new Species of Plays, since call'd Dramatick Opera's, of which kind were the Tempest, Psyche, Circe, and others, all set off with the most expensive Decorations of Scenes and Habits, with the best Voices and Dancers.' ${ }^{2}$ French actors and 'Italian merry-andrews' who 'quite debauched the stage with lewd grimace' left 'their itch of novelty behind.' 3 To such conditions the minor Restoration playwrights responded by increasing attention to theatrical rather than to dramatic effects.

It seems advisable to conclude this chapter with some account of two dramatists who form convenient links between the earlier and later Restoration writers of tragedy. JoHN BANKs (fl. I696) began a prolific career with The Rival Kings (I677). ${ }^{4}$ His real success came in exploiting the vein of English historical tragedy. The Unhappy Favourite (1682) deals with the Earl of Essex; The Island Queens, printed in 1684, and produced as The Albion Queens in I704, deals with Elizabeth and Mary, Queen of Scots; Vertue Betray'd (I682), with Anne Boleyn.

1 ' Prologue for the Women,' Works, Scott-Saintsbury edition, $\mathbf{X}$, 317. See also Prologue, Ibid., $\mathrm{X}, 318-320$.

${ }^{2}$ Apology, Lowe edition, I, 94.

' Dryden's 'Epilogue to the University of Oxford, 1673,' Works, Scott-Saintsbury edition, $\mathbf{X}, 382$.

- The date and title suggest the influence of Lee's Rival Queens. 
A later tragedy, Cyrus the Great, or The Tragedy of Love (I696), reverts more definitely to the stock material of heroic drama in basing its theme on Madeleine de Scudéry's romance. Despite an evident prejudice for the Continental unities and the simplification of scenes and characters, Banks ranted in 'Cambyses' vein,' and indulged in Cyrus the Great in a gruesome episode in which Panthea reassembles on the battlefield the disjecta membra of her dead lord. Banks won theatrical, rather than dramatic, success, and stimulated interest without touching real emotion.

A far more important link between earlier and later tragedy was Thomas Southerne (I660-I 746). Although one of his comedies reminded Dryden of Terence, ${ }^{1}$ Southerne is now remembered as a writer of tragedy. The Loyal Brother, or The Persian Prince (I682), is a blank-verse tragedy with some admixture of prose. A succession of comedies was followed by two very considerable successes in tragedy, The Fatal Marriage, or The Innocent Adultery (I694), and Oroonoko, or The Royal Slave (I696), both founded on novels of Mrs. Behn. These plays found continued favour in the eighteenth century, the former, in Garrick's version, Isabella, or The Fatal Marriage (I757), the latter, in Hawkesworth's alteration in I759. Both adapters removed from these works the scenes of dull comedy. The Fate of Capua (I 700) and The Spartan Dame (I7I9), in which he turned to classical themes, and an unimportant comedy

1 Dryden's verses, 'To Mr. Southern; on his comedy called The Wives Excuse,' in 1692 quarto of The Wives Excuse. 
prolong Southerne's dramatic career through the first quarter of the eighteenth century. Yet his most successful achievement was in the tragedies which, at the close of the seventeenth century, help to bridge the gap between the Restoration and the Augustan age. With something of Otway's dramatic pathos, though without his genius, Southerne points the way, perhaps, toward the sentimental drama of the eighteenth century. The school which Richard Steele is usually held to have founded seems foreshadowed, however unconsciously, in the almost feminine appeal of Otway and Southerne to the sentiment of pity. 


\section{CHAPTER VIII}

CONGREVE, VANBRUGH, AND FARQUHAR

THE Revolution of $\mathrm{r} 688$ is without the immediate significance to English drama of the Restoration of 1660. Political change did not bring forthwith dramatic reform. Yet, if the outward aspect of drama responded but slowly to the passing of the old régime, its inner life soon felt the stirrings of a new spirit. As the license of the earlier Stuart Court gave way to the healthier moral tone of the reign of William and Mary, a different standard was set for imitation. Latent forces of decency and moral restraint, which had been obscured by the dazzling vices of royalty and fashion, now began to reassert themselves. The very excesses of the Restoration brought natural reaction. If the pendulum had swung during the interregnum to the extreme of dramatic restraint, it had touched after the reopening of the theatres the extreme of license. An awakening moral sense could neither applaud nor condone the sins of the drama. Disapproval soon grew to direct attack. In his Prefaces to Prince Arthur (r695) and to King Arthur (r697), ${ }^{1}$ Sir Richard Blackmore remonstrated with the excesses of recent dramatists, and, early in 1698 , George Meriton issued a pamphlet,

1 These two 'heroick poems' and their separate prefaces have often been confused. The later preface highly praises Congreve's Mourning Bride. 
Immorality, Debauchery, and Profa[ne]ness Exposed. Random attacks, however, turned to concentrated assault in Jeremy Collier's $A$ Short View of the Immorality, and Profaneness of the English Stage (1698). With much of the Puritan spirit whose intolerant expression had brought disaster to William Prynne, Collier set himself squarely against prevalent immorality in drama. It should be said, at the outset, that not Jeremy Collier alone, but the power of public opinion, carried the day. Not in the virulence of his invective, but in the essential soundness of his cause, lay Collier's real strength. It was his good fortune to voice audibly the growing convictions of many. The soil was ready for good seed. A generation earlier he might have raised the voice of protest with no more effect than the blind poet who had fallen upon evil days. Yet if Collier is not to be regarded as the single-handed reformer of the stage, it is idle to ignore the outspoken, though ill-balanced, energy with which he formulated a more or less intangible public sentiment. To the slowly gathering force of moral reform he gave direct impetus. His definite challenge to Restoration dramatists could not be evaded. The number and energy of the replies evoked from his adversaries, and the confessions of their leader, Dryden, show that he had struck home.

Before entering upon a more detailed examination of Collier's work and its effect upon the tone of English drama, it will be well to resume the course of dramatic history with some account of the later dramatists whose careers began before the bursting of the storm, and who maintained even to the end 
much of the earlier spirit of Restoration drama. The last decade of the seventeenth century marks the advent of three important writers in whose work Restoration comedy touches its zenith - Congreve, Vanbrugh, and Farquhar. With a single exception, Congreve's plays preceded Collier's attack, but much of Vanbrugh's work and all of Farquhar's followed it.

In an age that prided itself on wit and elegance of style, WILlIAM CoNGREve (I670-I 729) was the wittiest and perhaps most graceful writer of English comedy. Born near Leeds, schooled at Trinity College, Dublin, Congreve came to London as a law student, published a minor novel, contributed to a poetical translation of Juvenal, and at twenty-three had won Dryden's favour and general applause with his first comedy, The Old Bachelor (I693). Dryden declared that 'he never saw such a first play in his life, and that the author not being acquainted with the stage or the town, it would be a pity to have it miscarry for want of a little assistance; the stuff was rich indeed, only the fashionable cut was wanting.' 1 This assistance Dryden himself helped to give, and Southerne, an early sponsor for Congreve, generously hailed him as Dryden's successor. ${ }^{2}$ In comparison with Congreve's later work, The Old Bachelor won disproportionate success. Its characters were largely conventional, yet even Captain Bluffe, a cowardly blusterer anticipated in the first English comedy,

1 Gosse, Life of William Congreve, pp. 33-34.

${ }^{2}$ See his striking lines To Mr. Congreve, on The Old Bachelor, Mermaid edition of Congreve, p. 3 . 
Ralph Roister Doister, has a certain vividness and individuality. Fondlewife recalls Wycherley's Pinchwife, and Heartwell, the 'surly old Bachelor, pretending to slight Women, secretly in love with Silvia,' has some touches of Manly, while some of the characters of the underplot suggest Jonsonian humours. Yet if The Old Bachelor somewhat lacks originality in characterization, Bellmour's words in the opening act might well have been Congreve's own invocation, 'Wit, be my faculty!' It was more than a decade and a half since Etherege had produced The Man of Mode and Wycherley had taken a cynical farewell of comedy in The Plain Dealer. With a style more graceful than Etherege's and wit more sparkling than Wycherley's, Congreve showed that there had appeared a new master of comedy.

Though far less gross and brutal than Wycherley, Congreve has a tone of subtle but pervasive immorality which he later strove vainly to disprove. In answer to Jeremy Collier he urged that the end of a play pointed the moral. Unfortunately Collier ${ }^{1}$ found the real moral of The Old Bachelor in its closing lines:

What rugged ways attend the noon of life!

Our sun declines, and with what anxious strife, What pain we tug that galling load, a wife!

In the Epistle Dedicatory prefixed to his next play, The Double-Dealer (1693), Congreve makes an unconvincing reply to the charge that 'some of the ladies

1 A Defence of the Short View . . . Being a Reply to Mr. Congreve's Amendments, \&c. And to the Vindication of the Author of the Relapse, 1699, p. 19. 
are offended' by its immorality. It is fair to note, however, that, in the dénouement, Cynthia's virtue escapes even Maskwell's plots and is rewarded by union with Mellefont, Lady Touchwood is driven off by her husband with an orthodox 'Go, and thy own infamy pursue thee,' and Maskwell is seized and held for punishment. Though all is not well that ends well, the curtain no longer falls on the dishonoured husband amid derisive laughter.

In the Epistle Dedicatory, Congreve claims originality of plot and deliberate intention 'to preserve the three unities of the drama.' Yet the admirable scandal scene (III, 3) recalls Olivia's scene with Novel and Plausible, ${ }^{1}$ and Molière's still earlier passages in Le Misanthrope, while the obscure turns in the labyrinth of plot are even further complicated by a network of bypaths and meanders. Congreve has perplexity, not unity, of action. The characters of The Double-Dealer are familiar types - Mellefont, the lover, Careless, the confidant, Maskwell and Lady Touchwood, villains, Lord Froth and Brisk, coxcombs, Lady Froth, 'a great Coquette,' Lady Plyant, 'insolent to her Husband, and easy to any pretender.' Lady Plyant's sesquipedalian words possibly suggest Mrs. Malaprop, but there is little 'mathemacular demonstration,' to borrow one of her phrases, of Mrs. Malaprop's 'nice derangement of epitaphs.' Even with the aid of the soliloquy, a de-

${ }^{1}$ Wycherley, The Plain Dealer (II, I). Yet Cynthia turns with disgust from the gossip which Olivia welcomes. Cf. Maria's and Sir Peter Teazle's disgust with the scandal-mongers in The School for Scandal. 
vice comparatively infrequent in Restoration comedy, though defended by Congreve in the Epistle Dedicatory, the devious ways of Maskwell are followed with difficulty. Plot is subordinated to brilliancy of dialogue. The numerous technical defects in dramatic construction perhaps account for the somewhat indifferent reception at first accorded The Double-Dealer, but its vividness of characterization and vitality of phrase eventually established it in a popularity which lasted through the eighteenth century.

Love for Love (I695) was the first play produced at the new Lincoln's Inn Fields Theatre, by Betterton and the actors who had revolted from the Patent Theatres. Its success was well merited, for in it wit is married to grace of diction. Valentine, a young spendthrift who is lucky in love, has had many successors in English comedy, among them, Young Honeywood in Goldsmith's Good Natur'd Man and Charles Surface. His wit does not stop with his assumption of madness. In a way that curiously recalls Hamlet,' he 'uses his folly like a stalking-horse and under the presentation of that he shoots his wit.' Jeremy, his witty servant, takes after his master, as do Sheridan's Fag and David. Jeremy, who 'waited upon a gentleman at Cambridge,' cites Epictetus, Seneca, Plato, and Diogenes in a single speech, as readily as Fag alludes to Jupiter's masquerades in love. The ceaseless showers of wit fall alike on master and man. Sir Sampson Legend, Valentine's father, is a vigorous portrait of the crusty father. Scandal is the familiar confidant of Restoration

1 Compare, e.g. IV, 2, with some of Hamlet's speeches to Polonius. 
comedy, not too busy to neglect his own intrigue. Foresight, 'pretending to understand Astrology, Palmistry, Physiognomy, Omens, Dreams, \&c,' though in point of fact not an anachronism, seems dramatically a Jonsonian character, out of place amid Congreve's beaux and belles. Miss Prue, an admirable example of the Restoration perversion of the ingénue, is essentially of the same type as Wycherley's Mrs. Pinchwife and Miss Hoyden in Vanbrugh's Relapse. Miss Prue has some admirable scenes - one where Tattle initiates her into the mystery of saying one thing while meaning the opposite - another with her sailor suitor Ben, ${ }^{1}$ whose awkward advances lead to a mutual disagreement which anticipates the scene of Tony Lumpkin and Miss Neville. Comedy borders dangerously upon farce when Tattle, thinking he is wedding Angelica in nun's disguise, is tricked into marriage with Mrs. Frail - a situation possibly saved by the fact that the marriage takes place off the stage. Congreve's Dedication of the play shows that he was not unconscious of the danger in its length, but unflagging zest of dialogue, skill in characterization, and more effectiveness in plot construction than he usually attained made Love for Love an acting comedy success.

Congreve's sole tragedy, The Mourning Bride (I697), has often been viewed as a solitary excursion into an alien dramatic field, and unrelated to his comic work. Yet in the villainy and passion of Maskwell and Lady Touchwood may be found strains

${ }^{1}$ Gosse, Congreve, p. 76, calls Ben 'the founder of a long line of stage-sailors, of whom he is the earliest specimen.' 
of tragic suggestion, just as Wycherley's Plain Dealer does not depart too far from Le Misanthrope to forget entirely the grim aspect of misanthropy. Doubtless it would be fantastic to exaggerate in Wycherley and Congreve the sombre threads in the weave of comedy, yet the latter's venture into the realm of tragedy is perhaps not an extraordinary and unheralded phenomenon. From the modern standpoint it seems the irony of fate that The Mourning Bride achieved in its own day greater success than Congreve's comedies. It held the boards through most of the eighteenth century, and the passage at the end of the first scene of the second act elicited Doctor Johnson's famous eulogy of it as 'the finest poetical passage he had ever read' ${ }^{1}$ - a dictum whose extravagance has reacted too severely against even a reasonable appraisal of a fine passage. The customary modern verdict, that Congreve's departure from comedy proved his incapacity for tragedy, is perhaps testimony to the change of popular taste quite as much as to the author's lack of judgment in essaying an uncongenial task. Plot and characters are, indeed, artificial, and the probabilities are stretched almost beyond the limits of the possibilities. That its writing took three years suggests that it was a tragedy not born, but made. Yet Congreve's shortcomings are those of all but a few of the Restoration tragic dramatists. The Mourning Bride, in fact, though written in blank verse, resumes in many respects the habits of heroic drama. It develops themes of love and honour in the foreign setting of Granada, and adopts a happy

1 Boswell's Life of Dr. Johnson, Hill edition, II, 85. 
issue for the heroic loves of the Princess Almeria and the noble Osmyn. The modern reader might prefer either a full tragic solution or an anticipation of the dénouement by a somewhat lighter handling of the earlier tragic elements. The final surprise seems rather a let-down than a wind-up. There has been no comic relief, and the advent of Osmyn at the end comes as a fortuitous trick, not as a logical dramatic climax. The plot, complicated by the motives of 'cross purposes' and 'mistaken identity,' has, apart from its artificiality, more coherence and vigour in development than is characteristic of Congreve's comedies.

Gosse believes that the blank verse 'is the parent of Thomson's,' and that Congreve's real model is Milton. ${ }^{1}$ Apart from such possible bearings on the history of poetry, Congreve's verse is of interest chiefly in some good, if rather conventional, lines, some of which are familiar in quotation. The Prologue sets a higher standard than Congreve attained either in comedy or in tragedy:

To please and move has been our poet's theme, Art may direct, but nature is his aim;

And nature missed, in vain he boasts his art,

For only nature can affect the heart.

Congreve is a great literary artist, but without the gift that blends art with nature.

The Dedication of The Mourning Bride had termed it a 'poem constituted on a moral whose end is to recommend and to encourage virtue.' This high 
purpose did not shield Congreve from Collier's determined attack in the following year, nor did that attack deter the dramatist from one further venture in comedy. Notwithstanding the fact that The Way of the World ( 1700 ) contained Congreve's most brilliant character creation, it met with a reception so lukewarm that the author was somewhat piqued. 'But little of it,' he writes in his Dedication, 'was prepared for that general taste which seems now to be predominant in the palates of our audiences.' Even Steele, in his Commendatory Verses, admits that it was caviare to the general by asking :

How could, great author, your aspiring mind Dare to write only to the few refined ?

Congreve's Dedication voices a deliberate intention to depict not the gross fools 'which are meant to be ridiculed in most of our comedies' but 'some characters which should appear ridiculous, not so much through a natural folly (which is incorrigible, and therefore not proper for the stage) as through an affected wit; a wit, which at the same time that it is affected, is also false.' With evident pique at critics who ,failed to note such subtleties, Congreve added that 'this play had been acted two or three days, before some of these hasty judges could find the leisure to distinguish betwixt the character of a Witwoud and a Truewit.' In a letter to Dennis, ${ }^{1}$ Congreve had defined 'humour' as 'A singular and unavoidable Manner of doing or saying any thing, peculiar and

1 ro July, 1695, 'Concerning Humour in Comedy,' The Select Works of Mr. John Dennis, 1718, II, 514-525. 
natural to one Man only; by which his Speech and Actions are distinguish'd from those of other Men,' and had declared that 'Humour is from Nature, Habit from Custom, and Affectation from Industry.' He had further asserted: 'The saying of humorous things does not distinguish Characters; for every Person in a Comedy may be allow'd to speak them. From a witty Man they are expected; and even a Fool may be permitted to stumble on 'em by chance. Tho I make a difference betwixt Wit and Humour; yet I do not think that humorous characters exclude Wit: No, but the Manner of Wit, should be adapted to the Humour.' Yet Congreve's own weakness lay in his inability to adapt his own wit to the various characters he should have differentiated. His 'fools' are permitted to stumble on too many brilliants. His diamond beds are without sand. Even in The Way of the World, Foible, the maid, like Congreve's earlier servants, has the wit of her betters. The unconscious humour of Goldsmith's Diggory is closer to life than the brilliant quips of Congreve's servants. It is small wonder that critics overlooked a theoretical distinction that seemed without a difference in practice.

Yet if, in Dryden's words, The Way of the World 'had but moderate success, though it deserves much better,' ${ }^{1}$ the judgment of posterity has gone far to correct the error. Millamant, Congreve's most brilliant character creation, has commanded Hazlitt's eulogy ${ }^{2}$ and George Meredith's tribute to the 'perfect

1 Letter to Mrs. Steward, I2 March, I 700. Quoted by Ward, III, 475.

${ }^{2}$ Lectures on the English Comic Writers, Lecture IV, pp. I39-142. 
portrait of a coquette.' 1 They had been anticipated, however, by an earlier critic, her lover Mirabel: 'I like her with all her faults; nay, like her for her faults. Her follies are so natural, or so artful, that they become her; and those affectations which in another woman would be odious, serve but to make her more agreeable' $(I, 2)$. She enters with a flash, and goes off in a blaze of wit. Even amid the ceaseless pyrotechnics of Congreve her departure seems like the extinction of a brilliant rocket. Yet Millamant is an artificial creation - beautiful and fragile as Dresden china. She has the wit, but not the humanity, of Shakespeare's Beatrice.

Congreve's wit is his supreme strength and perhaps his greatest weakness. It led him to sacrifice not merely naturalness in character and dialogue, but effectiveness of plot. In his comedies the action usually halts while the train of wit passes gaily by. Sheridan, with greater dramatic art, showed that brilliant wit need not clog the movement of plot, for even the scandal scenes which have at times been instanced to the contrary have some justification, apart from their brilliancy, as a necessary background for Lady Teazle. Yet it would be unfair to judge Congreve chiefly by his defects. To supreme wit he added grace of diction. He has the ease of Addison. He is a sort of avant-courier of eighteenth-century felicity of phrase and delicacy of diction. Hazlitt's eulogy, if somewhat superlative in expression, is sound in essence: 'His style is inimitable, nay perfect. It is

${ }^{1}$ An Essay on Comedy, Constable edition, 1897, p. 35 . See also pp. 39-42. 
the highest model of comic dialogue. Every sentence is replete with sense and satire, conveyed in the most polished and pointed terms. Every page presents a shower of brilliant conceits, is a tissue of epigrams in prose, is a new triumph of wit, a new conquest over dulness.' In the record of English comedy Congreve holds a foremost place. His early work, especially The Old Bachelor, shows the influence, without the malignant bitterness, of Wycherley. In comic spirit he seems rather the descendant of Etherege and the ancestor of Sheridan. With Etherege's weakness in plot, he has greater ease of dialogue ; in brilliancy and ceaseless wit, he vies with Sheridan. In his hands the comedy of society is touched with rare literary skill. It is artificial comedy, but the art is masterly.

If, in a general sense, Congreve is a follower of Etherege, Wycherley's successor is Sir John VANBRUGH (I664-I 726). After some early architectural training in France and experience in the army which culminated in his seizure at Calais and imprisonment in the Bastille as a suspected spy, Vanbrugh settled down to the life of a dramatist and an architect. The combination of professions once came near to causing personal disaster. From Colley Cibber's account ${ }^{1}$ of the opening of the Haymarket Theatre, in I705, it appears that Vanbrugh almost wrecked his own play, The Confederacy, through the wretched acoustics of the theatre in which he had sacrificed too much to spaciousness of dome and splendour of construction. Flemish in descent, Vanbrugh had a taste for the massive in architecture, to which his mock epitaph bore witness :

${ }^{1}$ A pology, Lowe edition, I, 3 I9 ff. 
Lie heavy on him, Earth! for he Laid many heavy loads on thee! ${ }^{1}$

In character painting, too, he shows at times a certain Flemish heaviness, a following of the 'fleshly school' of Rubens. Whether Swift was right in satirizing some of Vanbrugh's efforts in architecture, or Sir Joshua Reynolds was justified in praising the picturesque effect of Blenheim, which Vanbrugh built for the Duke of Marlborough, is, from the present standpoint, of less moment than the fact that his prominence as an architect enforced his notoriety as a dramatist.

Vanbrugh's dramatic fame rests chiefly upon three comedies - his first, The Relapse, or Virtue in Danger (Dec. 1696), The Provok'd Wife (1697), and The Confederacy (1705). Of his minor pieces, Assop (1697) is a free translation of a French comedy by Boursault, The Pilgrim ( 1700 ), an adaptation from Fletcher, The False Friend (1 702), from Le Sage's version of a Spanish comedy, The Country House (I705), from one of Dancourt's farces, and The Mistake (1705), from Molière's Le Dépit Amoureux. A Journey to London is an unfinished comedy, completed by Colley Cibber as The Provoked Husband. The chief interest of most of these minor pieces lies in the illustration of Vanbrugh's variety of materials.

The success of Colley Cibber's uninspired, but wellconstructed and well-acted, comedy, Love's Last Shift, or The Fool in Fashion, suggested a sequel. Written in six weeks, The Relapse was presented to

1 On Sir J. Vanbrugh; an epigrammatical epitaph [by Dr. Evans]. In John Nichols's Select Collection of Poems, 1780-82, III, 161. 
the Drury Lane management in April, I696, and produced in December. Vanbrugh took three characters from Cibber - Loveless, the libertine, Amanda, the virtuous spouse, and Sir Novelty Fashion, who becomes Lord Foppington. Cibber, the first Sir Novelty Fashion, and the actors who had appeared as Loveless and Amanda, continued their original successes in Vanbrugh's sequel. The comparison between Cibber and Vanbrugh centres in the figures of Sir Novelty Fashion and Lord Foppington. From Cibber, Vanbrugh has taken the general idea of the fop and some specific touches. In Cibber, Sir Novelty is described as 'one that Heaven intended for a Man; but the whole business of his Life is, to make the World believe, he is of another Species' (Act I). Cibber's character amuses for the moment; Vanbrugh's has permanent vitality. Hazlitt, ${ }^{1}$ who regards Lord Foppington as a 'copy from Etherege's Sir Fopling Flutter,' thinks that 'perhaps, Sir Fopling is the more natural grotesque of the two,' but he does not fail to regard Lord Foppington as 'a most splendid caricature.' Dr. Ward ${ }^{2}$ remarks, 'Lord Foppington I am inclined to pronounce the best fop ever brought on the stage - unsurpassed and unsurpassable, and admirable from first to last.'

In The Relapse virtue, in the person of Amanda, triumphs. Yet, as the sub-title of the play implies, virtue is very much in danger. Furthermore, though Amanda resists temptation, Loveless prosecutes his intrigue with Berinthia to its relentless end. Com-

${ }^{1}$ Lectures on the English Comic Writers, pp. 157-1 58.

2 Ward, III, 479. 
pared with Wycherley, Vanbrugh's immorality seems less black, because it is gayer and less cynical. He seems, for the most part, to have the buoyancy of animal spirits rather than the brutality of animal passions. Yet in The Provok'd Wife, Sir John Brute does not belie his name. He is of the beef-and-beer school, an alehouse brawler, with a bully's cowardice. Like Sir Tunbelly Clumsey in The Relapse, he shows Vanbrugh's heavy Flemish touch. Constant and Heartfree are the usual pair of friends, Rasor and Mademoiselle the clever valet and maid. Lady Brute and Belinda are the confidantes. Yet these are not lifeless reproductions of stock characters, but vitalized individuals. The Confederacy, largely taken from Dancourt's Les Bourgeoises a la Mode, shows much skill in plot construction. The way in which the plot is made to turn on the possession of a necklace recalls somewhat Goldsmith's later handling of Miss Neville's jewels in She Stoops to Conquer. Despite marked obligations to its French original, Vanbrugh's play has individuality. Dick Amlet and his mother and Brass are vigorous character creations.

Unlike Etherege and Congreve, Vanbrugh excels in dramatic construction. The Relapse is doubtless too long, and Sheridan, who revised the play under the title of $A$ Trip to Scarborough, though he sacrificed some of the pristine vigour of his original, improved the plot by considerable cuts and some rearrangement, especially in the last part. But, for the most part, Vanbrugh's plots, like Wycherley's, though often borrowed, are skilfully built, easily followed, and productive of excellent stage situations. The effective- 
ness of plot is enhanced by distinctness of character drawing. Sometimes, indeed, he outlines his sketches so heavily that they approach caricature, as in Lady Fancyful, the female fop in The Provok'd Wife. His portrait of Lord Foppington merits the place of honour, yet many of Vanbrugh's other pictures deserve to be hung on the line. Young Fashion, the gallant, Sir Tunbelly Clumsey, the country gentleman, Flippanta, the soubrette maid, Miss Hoyden, the romping ingenue, Amanda, the virtuous wife, Berinthia, the reckless widow, Sir John Brute, the sottish squire, Rasor, the clever valet - these, and others, show Vanbrugh's power of touching the stock characters of the comedy of his day with vigour and vitality.

Without the epigrammatic skill of Congreve, Vanbrugh has admirable ease and fluency of style. Colley Cibber, who acted several of the strongest parts, confirms by his own testimony what he records as the general observation of 'all the Actors of my Time, that the Style of no Author whatsoever gave their Memory less trouble than that of Sir John Vanbrugh,' and that 'his Wit and Humour was so little laboured, that his most entertaining Scenes seem'd to be no more than his common Conversation committed to Paper.' 1 In his best work, well-rounded strength in plot, character, and dialogue, deservedly won signal success in comedy.

GEORGE FARQUHAR ( $1678-$ I 707 ) brought to English comedy an endowment of native Irish wit, goodhumour, and originality. Of Londonderry birth, a sizar at Trinity College, Dublin, and then an actor on

${ }^{1}$ Apology, Lowe edition, I, 219. 
the Dublin stage, he was brought by Wilks to London. His first play, Love and a Bottle, appeared when he was perhaps twenty. ${ }^{1}$ A commission in the army and a visit to Holland with his regiment gave him military experience on which he drew in his later comedies. It was Farquhar who discovered the sixteen-year-old niece of the hostess of the Mitre Tavern reading behind the bar one of Beaumont and Fletcher's plays, interested Vanbrugh in her, and through him brought to Christopher Rich the actress who was to become famous as Nance Oldfield. Farquhar's second play, The Constant Couple, or A Trip to the Jubilee (1699), was a highly successful comedy. Its hero lent his name to a sequel, Sir Harry Wildair (I70I), which increased the popularity of Farquhar's dramatic portrait of a gentleman 'newly come from Paris,' endowed with 'gaiety of humour.' ${ }^{2}$ The Inconstant, or The Way to Win Him (I702) was taken from Fletcher's The Wild Goose Chase. The Twin Rivals ( 1702 ) contains a humpback villain and a rather amusing Irish servant, Teague. The Recruit ing Officer ( 1706 ), animated by Farquhar's own military experience, enlarges the bounds of comedy that had hitherto been too closely confined to city limits and the gallantries of its fops. The vigorous characters of Sergeant Kite and Captain Plume have the rough freedom of a country atmosphere.

The Beaux' Stratagem (1707) shows both the traditions of Restoration comedy and the advent of new

${ }^{1}$ Genest dates it 1699 , but the first edition, dated 1699, actually appeared in December, 1698.

The Constant Couple, I, r. 
tendencies. Here are present in full force the familiar flings of the beau monde at the country, and yet something of real country atmosphere; French characters and phrases, ${ }^{1}$ and yet a hearty English element ; much of the immorality of earlier comedy, with some of the later improvement in moral tone. Though Squire and Mrs. Sullen separate at the end with scant regard for the marriage tie, Farquhar does not scoff at virtue and exalt vice in Wycherley's fashion. The seeming intrigue between Mrs. Sullen and Count Bellair is only her scheme to solve her matrimonial troubles. Instead of trying to deceive her husband, she has him brought to her rendezvous with the Count. As the Count says, when Mrs. Sullen shows him that she has not taken his advances seriously: 'Begar, madam, your virtue be vera great, but garzoon, your honeste be vera little' (III, 3 ).

The dialogue is bright, witty, and vigorous. Mrs. Sullen, who epitomizes her husband as 'a sullen, silent sot' breaks out with these words: 'Since a woman must wear chains, I would have the pleasure of hearing 'em rattle a little' (II, I). Archer and Cherry have some excellent passages. ${ }^{2}$ Though Mrs. Sullen's long speeches (II, I) voice the usual contempt of the town for the country, the play has genuine country atmosphere. The countrywoman who comes to Lady Bountiful to have her husband's leg cured is given, in fact, some dialectic forms of speech - 'mail' for 'mile,' and 'graips' for 'gripes' (IV, I). Scenes with

${ }^{1}$ Besides Count Bellair, there is Foigard, an Irishman who tries to make his speech pass for French.

2 End of I, I, and of II, 3, with Archer's catechism of love. 
the landlord, the tavern maid, and the highwaymen come as a relief from the ceaseless intrigues of fashionable London.

The plot construction is highly ingenious, especially in the very effective last act. Archer - whose name is sufficiently explained by Boniface's words (II, 3), 'You're very arch' - justifies his name by replacing the French Count at the rendezvous, and obtains entrance to Mrs. Sullen's chamber. This leads to a situation familiar in Restoration comedy in such scenes as Vanbrugh's, where Loveless carries off Berinthia (The Relapse, IV, 3), and Farquhar's own scene in his Love and a Bottle, where Roebuck invades Lucinda's chamber. But the ingenuity with which a stock situation is rescued from the relentless issue in Vanbrugh is Farquhar's own. The attempted robbery not merely interrupts the amour at the critical point, but offers an effective chance for Archer to display his bravery and to merit Mrs. Sullen's regard. Mrs. Sullen herself well describes him: 'The devil's in this fellow ! he fights, loves, and banters, all in a breath' $(\mathrm{V}, 4)$. The next scene is full of rapid movement of plot and shift of situation. The whole act, handled with vigorous assurance, is of sustained interest.

Farquhar is to some extent a forerunner of Goldsmith. The opening conversation between Boniface, the innkeeper, and Aimwell and Archer about the menu is quite like that of Mr. Hardcastle, the supposed innkeeper, with Marlow and Hastings in She Stoops to Conquer. There is something, too, in the freshness of atmosphere, in the group of country and 
inn folk, and in the Irish good-humour, which is akin to the spirit of Goldsmith. Whatever Farquhar's lapses in point of morality, he has none of Wycherley's vindictive and brutal cynicism. Most of his characters, with all their faults, are companionable. They are not so clever as Congreve's, but fertile brains and facile manners make them attractive, despite some heartless traits.

While Wycherley adapted Molière and Vanbrugh followed a variety of models, Farquhar's ready brain was responsible for most of his effectiveness in plot and characters. Farquhar usually suggests to others. Highwaymen in league with the landlord may be as old as the First Part of Henry IV, but both Goldsmith's She Stoops to Conquer and Gay's Beggar's Opera may have found a nearer model in The Beaux' Stratagem. Farquhar imparts to his characters individuality. He presents a whole gallery of full-length portraits the country squire, the Irish adventurer, the fop, the landlord, the tavern maid, the recruiting officer. $\mathrm{He}$ sets them in scenes vivid in their portrayal of eighteenth-century life. The inn, the country house, the gatherings of soldiers and highwaymen, enlarge a canvas which has usually represented only the fashionable world of courtier and intriguante. Effective in plot, varied in scenes and characters, Farquhar's last and best comedy brings Restoration comedy to a brilliant close, and points to the healthier humour of Goldsmith. 


\section{CHAPTER IX}

THE MORAL REAWAKENING

WIrh Congreve, Vanbrugh, and Farquhar, Restoration comedy draws towards its end. Its brilliant dramas continued to hold the boards for many years, and powerfully influenced eighteenth-century drama. Yet even Sheridan, on whom descended Congreve's mantle of wit, did not reproduce the traditional license of Restoration comedy. The awakening forces of moral reform to which Jeremy Collier gave their most decisive expression were steadily in the ascendant. Against them battled vainly the defenders of a lost cause. Neither the ridicule nor the serious arguments desperately essayed by opponents, nor even Collier's own absurdities, could avail against the solid strength of his main contention. Collier himself was less the prophet of an unrealized evil than a voice through which revolt against the immorality of the stage became fully articulate. Other voices had already been raised in partial protest. Evelyn's Diary expressed at times his regret at the license of drama, and even Pepys had not always been tolerant of the evils of the theatre of his day. James Wright's Country Conversations (1694) anticipated Collier in resenting the abuse of the clergy at the hands of dramatists, and suggested that 'now most of our New Comedies are become very Pictures of Immorality,' 
and Sir Richard Blackmore's Preface to Prince Arthur (1695) declared that 'The Poets that write for the stage (at least a great part of 'em) seem deeply concern'd' in a conspiracy to 'bring Vice and Corruption of Manners into Esteem and Reputation.' Collier's main attack was thus prefaced by various skirmishes. His success was due not to strategy, but to an impregnable position.

It is important to examine, in some detail, the real content of $A$ Short View of the Immorality, and Profaneness of the English Stage (1698). Vagaries of individual criticisms blend curiously with sound general truths. Collier has much of the Puritan intolerance of William Prynne's Histrio-Mastix and much of the inartistic obtuseness of Thomas Rymer's Short View of Tragedy. The first chapter, 'The Immodesty of the Stage,' an attack upon indecency of language, justly declares that 'The Present English Stage is superlatively Scandalous. It exceeds the Liberties of all Times and Countries.' ${ }^{1}$ Yet Collier, who finds some excuse for Aristophanes and for Fletcher, laments that Shakespeare keeps Ophelia alive 'only to sully her Reputation.' The second chapter, on 'The Profa[ne]ness of the Stage,' enters a sensible objection to swearing as 'an ungentlemanly, as well as an unchristian Practice,' but finds it 'a heavy Piece of Profaness' to call Jehu a 'Hackney Coachman.' 2 In the third chapter, 'The Clergy abused by the Stage,' Collier shifts from the moral to the social standpoint, in deprecating the representation on the

1 I698 edition, p. 54.

2 Ibid., p. 64 . 
stage of the priesthood, on the ground that this degrades 'the profession of a Gentleman.' ${ }^{1}$ The title of the fourth chapter shows that Collier could not readily go astray in seeking arguments from contemporary drama: "The Stage-Poets make their Principal Persons Vitious, and reward them at the End of the Play.' Chapter five singles out certain plays for attack, notably Vanbrugh's Relapse. At one moment, Collier justly upbraids Vanbrugh for permitting Berinthia to go off 'without Censure or Disadvantage,' but, in the next, cites as proof of her profanity a bit of persiflage about lovers' oaths which shows that Collier was not the man to laugh at lovers' perjuries." The final chapter, 'The Opinion of Paganism, of the Church, and State, concerning the Stage,' carries the discussion far afield. Heathen philosophers, orators, and historians, the constitutions of Athens, Sparta, and Rome, and the edicts of church councils, are marshalled into an attack not upon the abuses of the drama, his original target, but upon the stage itself. For a time he bids fair to challenge comparison even with the inimitable prolixity and absurdity of Prynne's Histrio-Mastix. In the end, however, he returns to the more definite charge that the stage 'cherishes those Passions, and rewards those Vices, which 'tis the business of Reason to discountenance.' $^{3}$

From even these illustrations it will be apparent that Collier's strength lay more in the justice of his

1 Ibid., p. 136.

2 Ibid., pp. 219-220.

Ibid., p. 287. 
cause than in sustained logic of argument. Had the basic truth of his general contention been open to question, he might easily have defeated his own ends. He often failed to distinguish between immorality and harmless jest, between moral and artistic issues. He poured censure alike on plays that rewarded vice and on those that violated the dramatic unities. $\mathrm{He}$ sought examples not even remotely connected with the real question, and did not hesitate to alter the question itself. Yet if he often fought as one that beateth the air, many of his blows landed with deadly strength. His pamphlet has at times zest and vivacity as well as blunt force. His work should be judged not merely by its flagrant eccentricities but by its underlying elements of strength.

So obvious are the immediate responses to his invective that Collier has at times been credited with originating rather than expressing a new moral standard. At all events, he remained the central figure in the war of pamphlets which prolonged for more than a quarter of a century. Charles Gildon, Edward Filmer, John Dennis, Vanbrugh, and Congreve ${ }^{1}$ all took up the cudgels in behalf of the stage within some four months from the publication of Collier's attack. Gildon, Filmer, and Dennis did not fail to admit in many respects the justice of his strictures, but took issue with his extreme arguments. Yet even Dennis, who had the candour to admit that 'No man can make any reasonable defence, either for the immorality or the immodesty, or the unnecessary wanton pro-

1 For titles and discussion of these pamphlets and those cited below, see Gosse's Congreve, pp. I I 2-I 29. 
phaneness which are too justly charg'd upon "1 contemporary drama, is partisan enough to defend Wycherley. Vanbrugh was able to pierce cleverly a few weak points in Collier's armour, but was far from finding a vital spot. Congreve for once found wit failing him, and anger a sorry substitute for argument. His reckless attempt to show that Collier's citations were proof of the critic's impurity fell flat, and Congreve soon learned that Vanbrugh had been right in admitting that the Short View was 'now a thing no farther to be laught at.' 2

Collier was not left to fight his battle single-handed. Early in September, two minor pamphlets took issue with Congreve's Amendments, and, not long after, The Stage Condemn'd brought him the doubtful aid of its dull prolixity. But Collier was not content to rest his case on his first main indictment. In November appeared $A$ Defence of the Short View, in which he dealt chiefly with Congreve and Vanbrugh. Other later treatises added bulk, rather than weight, to the controversy. Collier's answers to specific details of controversy seem to-day to detract somewhat from the concentrated force of his first invective. Still, his provocation was strong, and the severity of his personalities was fully matched by his opponents. Yet Dryden, despite flashes of very human resentment at Collier's extreme charges, ${ }^{3}$ bowed to the justice of the main indictment. ${ }^{4}$ While the tide of controversy

1 The Usefulness of the Stage, 1698, Introduction.

'Vanbrugh, A Short Vindication of the Relapse and the Proook'd Wife, 1698, p. 4 .

See beginning of Cymon and I phigenia.

- Preface to the Fables (1700), Essays, Ker, II, 272. 
still raged fiercely, he uttered what sounds more like the verdict of an impartial judge than the plea of the defendant :

Perhaps the parson stretched a point too far, When with our theatres he waged a war.

He tells you, that this very moral age

Received the first infection from the stage;

But sure, a banished court, with lewdness fraught,

The seeds of open vice, returning, brought. ${ }^{1}$

Congreve and Vanbrugh had reaped the whirlwind which had been sown in the court of the Merry Monarch.

The extent of Collier's influence upon the tone of English drama has been variously estimated. Not infrequently the question has been dismissed with positive assertion rather than with positive proof. Macaulay evidently assumed that Collier was practically responsible for the reform of the English stage. Recently, there has been a reaction, sometimes almost amounting to violence, against this once popular assumption. In its most aggressive form, modern criticism has sometimes gone so far as to deny Collier any influence upon contemporary drama and to dismiss his attack as a complete failure. This is to swing the pendulum to the other extreme. Enough has been said already to suggest the danger of assigning to Collier results of forces too far-reaching to be attributed to an individual. Yet distaste for what is intolerant and extravagant in Collier should not provoke a like intolerance in the critic. The course of

${ }^{1}$ Epilogue to The Pilgrim (I 700 ), Scott-Saintsbury edition of Dryden, VIII, 502. 
drama was not immediately and violently turned into a purer channel. Despite Collier's strictures, Farquhar and Vanbrugh, in his later plays, maintain the license of Restoration comedy, and the looseness of earlier Restoration comedies did not prevent their retention on the stage. Yet, if the superficial aspect of drama was not largely altered, there were indubitable signs of reaction against the immorality of the stage. The attitude of the law and government is significant. In an excellent summary, supported by definite proofs, Dr. Ward says: ${ }^{1}$ 'The censorship of the Master of the Revels began to be exercised more strictly; actors were prosecuted for the use of profane language, and the playhouses were once more presented as nuisances by the grand-jury; the admission of women wearing masks into any of the theatres was prohibited; and Convocation occupied itself with the condition of the stage as a matter of moment to be pressed upon the consideration of the Crown.' The slow, but perceptible, influence upon the character of the dramatic output becomes more apparent with rising dramatists like Colley Cibber and Richard Steele. The effect of the pamphlet controversy over the morals of the theatre continued for almost a generation until William Law's treatise, The Absolute Unlawfulness of the Stage-Entertainment fully demonstrated (I 726). Collier's attack upon the stage may not, indeed, claim absolute priority in the dispute, but it focussed the discussion. It became the centre of attack and the rallying-point of defence. It would be idle to exaggerate to heroic proportions the medi- 
ocre figure of Jeremy Collier, but it would be unfair to deny him in the controversy of his day a prominence which his very opponents recognized.

The death of Dryden and the withdrawal of Congreve from dramatic work accentuate the passing of the old order. Whether the comparative failure of The Way of the World, or an uneasy sense of Collier's superiority in their controversy, or simply Congreve's fondness for the social life which the emoluments of office now permitted him to enjoy, was the dominant factor in the case, Congreve 'left the stage early.' And though the generous words of Dennis, that 'Comedy has quitted it with him,' 1 have the exaggeration of compliment, they suggest a truth. Even Farquhar, whose later work, with that of Vanbrugh, disproves the literal accuracy of the phrase, bore striking testimony to the significance of Collier's attack. His Preface to The Twin-Rivals (printed I 703) begins as follows: 'The success and countenance that debauchery has met with in plays, was the most severe and reasonable charge against their authors in $\mathrm{Mr}$. Collier's Short View; and indeed this gentleman had done the drama considerable service, had he arraigned the stage only to punish its misdemeanours, and not to take away its life; but there is an advantage to be made sometimes of the advice of an enemy, and the only way to disappoint his designs, is to improve upon his invective, and to make the stage flourish, by virtue of that satire by which he thought to suppress it.' Farquhar's play, however, by no means puts virtuous

${ }^{1}$ The Poetical Register: or, the Lives and Characters of the English Dramatick Poets [by Giles Jacob], 1719, p. 46. 
theory into practice. It was not through the reform of dramatists of the old school, but through the advent of new playwrights that comedy was to be purged of gross license.

Two years before Jeremy Collier's invective, appeared the first play of Colley Cibber (I671-I 757). Conspicuous in his own day as actor, manager of Drury Lane, playwright, and finally poet-laureate, Cibber lives to-day chiefly as the author of $A n A$ pology for the Life of Mr. Colley Cibber . . . Written by Himself, an entertaining record not merely of his own life but of the whole dramatic history of his times. In writing comedy Cibber avowed a deliberate moral intention. In comparing his first comedy, Love's Last Shift, or The Fool in Fashion (1696), with Vanbrugh's famous sequel, Cibber later wrote: 1 'The Relapse, however imperfect in the Conduct, by the mere Force of its agreeable Wit, ran away with the Hearts of its Hearers; while Love's last Shift, which (as Mr. Congreve justly said of it) had only in it a great many things that were like Wit, that in reality were not Wit: And what is still less pardonable (as I say of it myself) has a great deal of Puerility and frothy Stage-Language in it, yet by the mere moral Delight receiv'd from its Fable, it has been, with the other, in a continued and equal Possession of the Stage for more than forty Years.' Despite its 'moral delight,' the play did not escape the censure of Jeremy Collier, though Cibber protests ${ }^{2}$ that 'his greatest Charge against it is, that it sometimes uses the word

1 Apology, Lowe edition, I, 220.

2 Ibid., I, 274. 
Faith! as an Oath, in the Dialogue.' Modern taste might find a stronger objection to the ease with which a faithless husband, after eight years' quest of pleasure, is permitted to reclaim a faithful wife. Yet difference in moral standards rather than insincerity on Cibber's part may fairly account for apparent ethical shortcomings.

Cibber's alteration of Richard III gave to the stage a famous acting version, for more than a century the accepted stage text. Some minor comedies, one of which was drawn partly from Fletcher and another from a Spanish source, ${ }^{1}$ were followed by Cibber's most conspicuous success in comedy. In The Careless Husband ( 1704 ) he seeks definitely to moralize comedy. Yet Cibber's play is rather an expurgated Restoration comedy than a new comedy type. The plot is twofold. Sir Charles Easy, the 'Careless Husband,' engages in amours with Lady Grave-Airs and Edging, his wife's maid. Lord Morelove, coquettishly allured and repulsed by Lady Betty Modish, pretends affection to Lady Grave-Airs, while Lady Betty flirts with Lord Foppington. The seven characters are familiar comic types. Lady Betty Modish is the coquette of the school of Congreve's Millamant. Lady Grave-Airs is the cast-off mistress, like Congreve's Belinda, in The Way of the World. In Lord Foppington, Cibber reclaims the fop that Vanbrugh had taken from Cibber's Sir Novelty Fashion. All these fops are of the school of Etherege's Sir Fopling Flutter and Crowne's Sir Courtly Nice. Yet Cibber's Lord Foppington is no mere echo. Lady

1 Ward, III, 486. 
Easy is the one character who is represented as ethically admirable. In the scene where Lady Easy finds her husband and the maid asleep in chairs, founded according to Boswell ${ }^{1}$ on fact, Lady Easy's ascent from prose to blank verse in apostrophizing her sleeping husband is striking. But when, anxious like a good wife lest he catch cold 'bare-headed and in so sound a sleep,' she determines to intercept the wrath of 'Heav'n offended' and 'takes her Steinkirk from her Neck, and lays it gently over his Head,' she relapses, appropriately to the anti-climax, into prose. Steele's earlier introduction of blank verse in plays like The Funeral (I 701) and The Lying Lover (I 703) points to an attempt to invest the serious passages of moralized comedy with the traditional dignity of verse.

The Lady's Last Stake, or The Wife's Resentment (I707) inculcates the same moral as The Careless Husband - that love, not jealousy, binds the wife to the husband's heart. Of The Non-Juror (I7I7), an adaptation of Molière's Tartuffe to English setting, Cibber wrote: ${ }^{2}$ 'I borrow'd the Tartuffe of Moliere and turn'd him into a modern Nonjuror: Upon the Hypocrisy of the French character I ingrafted a stronger Wickedness, that of an English Popish Priest lurking under the Doctrine of our own Church to raise his Fortune upon the Ruin of a worthy Gentleman, whom his dissembled Sanctity had seduc'd into the treasonable Cause of a Roman Catholick Out-law.' The Non-Juror contains some well-drawn characters,

1 Life of Johnson, Hill edition, I, I 74, footnote 2.

2 A pology, II, 186. 
and its bold strokes of caricature are retouched in Isaac Bickerstaff's The Hypocrite ( $\mathrm{I} 768$ ), but Cibber's attempt to blend politics with morals is a dubious procedure. The Provoked Husband (I 72:8), a completion of Vanbrugh's unfinished comedy, $A$ Journey to London, encountered, according to Cibber, ${ }^{1}$ the resentment which people had not dared to show openly to the political tone of The Non-Juror.

In another connection, there will be good reason to discuss Cibber's resolute championship of 'legitimate drama' against the encroachments of pantomime and spectacle. Here, it is of primary importance to centre attention on his conscious moral aim. The Dedication of The Careless Husband shows an evident wish to reform contemporary comedy; the Prologue declares the intention not to deal with the grossness of 'the Vile Scum' of humanity who 'deserve not Satyrs but the Hangman's Lash,' but to hit 'some weak Part, where Folly's found.' Judged by modern standards, Cibber permits even gross folly and sin to be redeemed with ready indulgence. Yet, if Lady Easy does not belie her name in viewing her careless husband's errors, her position is treated not with ridicule, but with sympathy. If Cibber welcomes the homecoming of his prodigals with an easy forgetfulness of their lapses from virtue, he seeks to lay chief emphasis on the pure affection and constancy of their wives. Nor are his prodigals libertines 'as sensual as the brutish sting.' They are more akin to Tom Jones than to Wycherley's Horner. There is no reason to question Cibber's sincerity when, from the vantage- 
point of his later years, he reviewed his attitude toward the drama : ' 1 It has of ten given me Amazement that our best Authors of that time could think the Wit and Spirit of their Scenes could be an Excuse for making the Looseness of them publick. The many Instances of their Talents so abused are too glaring to need a closer Comment, and are sometimes too gross to be recited. If then to have avoided this Imputation, or rather to have had the Interest and Honour of Virtue always in view, can give Merit to a Play, I am contented that my Readers should think such Merit the All that mine have to boast of - Libertines of meer Wit and Pleasure may laugh at these grave Laws that would limit a lively Genius: But every sensible honest Man, conscious of their Truth and Use, will give these Ralliers Smile for Smile, and shew a due Contempt for their Merriment.'

Convenient illustration of the failure of much of the drama of the time to respond to suggestions for its moral betterment may be found in the work of MRS. Centlivre (I667 ?-I 723). Her comedies emphasize the fact that neither the preaching of Collier nor the practice of Cibber is indication of more than a general turn of the tide. For some two decades after Collier's attack, Mrs. Centlivre continued to write down to the level of vulgarity. Her first play, a blank-verse tragedy with some comic admixture, and a later tragedy with a happy solution are not wholly aloof from the comic vein which she chiefly worked. Aptitude for effective play construction and a certain ease of dialogue gave her best comedies theatrical life, if not

1 Ibid., I, 266. 
dramatic vitality. Though most of her characters, like Sir William Mode, in The Beau's Duel, or A Soldier for the Ladies (I702), are familiar comic types, Mrs. Centlivre occasionally chanced upon more individual characters. Conspicuous among these are Marplot in The Busie-Body (I709), and its sequel (I 7 IO), later known as Marplot in Lisbon, and Don Felix in The Wonder! A Woman Keeps a Secret (I7I4), one of Garrick's most successful rôles. Mrs. Centlivre's dramatic activities, which extended over smore than a score of years, concluded with a popular comedy, A Bold Stroke for a Wife (I7I8), and The Artifice (1722), which suggests the pervasive influence of sentimental drama. She had no hesitation in acknowledging indebtedness for material to Molière and to Spanish sources in some of her work, but she is not without skill in adapting materials to her own purpose and not without cleverness in infusing new elements. Her characters, though habitually superficial and conventional, sometimes found genuine favour on the stage. With little of the vigour and individuality which have preserved distinction for the greater Restoration dramatists, Mrs. Centlivre adopted but too readily their looseness. With small compunction, she sacrificed on the altar of expediency.

If the plays of Colley Cibber mark the transition toward healthier moral standards, the new movement in eighteenth-century drama is fairly inaugurated in the work of RICHARD STEELE (I672-I 729). To the conscious moral aim of Cibber, Steele added literary art and genius. Unfortunately, that genius 
did not lie naturally in drama. Like Addison, his humour was less for the footlights than for the quiet nooks of the coffee-houses. Though at first he broadened his humour to the coarser gauge of the playhouse, his later dramas shrank usually from such expedients. Like Cibber, Steele resolutely turned his back on the licentious, but the finer grain of his nature seems to have exacted for the most part a higher standard than that which satisfied Cibber. Since Steele lacked the vis comica and demonstrative wit needed for sustaining comedy without other aids, he sought for it a new prop. This he found in sentiment.

Steele was, in a sense, the founder of sentimental comedy. Yet it must not be thought that the field of which he took possession had lain hitherto wholly undiscovered. Perhaps the real origin of sentimental comedy should be sought not simply in the moralized comedy of Cibber but in the somewhat sentimentalized tragedy of Otway and Southerne. The rising tide of sentiment invaded the entire drama. Its appeal to pity touched a fundamentally tragic emotion. Its conscious moral aim was essentially serious., To regard sentimental comedy as a separate stream, whose ultimate source is Steele, is to disregard earlier and broader aspects of dramatic history. Furthermore, the eighteenth-century current of sentiment was not confined to drama. Later, it caught up and swept along novelists like Richardson and Sterne. Nor was it confined to English shores. Back and forth across the Channel swept its currents and countercurrents. English sentimental comedy from Steele 
CEAP.

to Hugh Kelly and Richard Cumberland is but one channel of the great stream of sentiment which sought an outlet by many mouths of a vast delta.

Before turning to the drama, Steele published, in I 70I, a religious tract, entitled The Christian Hero, which brought him the reputation among his comrades of being 'a disagreeable Fellow.' He then deemed it 'incumbent upon him to enliven his Character, for which Reason he writ the Comedy called The Funeral, in which (tho' full of Incidents that move Laughter) Virtue and Vice appear just as they ought to do.' 1 The Preface to The Funeral (I 7oI) declares that 'the innocence of it moved' the Duke of Devonshire 'to the humanity of expressing himself in its favour.' Yet Steele did not deny himself keen satire and humour so broad that it sometimes verges on farce. 'The subject of the drama 'tis hoped will be acceptable to all lovers of mankind,' says his Preface, 'since ridicule is partly levelled at a set of people who live in impatient hopes to see us out of the world, a flock of ravens that attend this numerous city for their carcases.' In the opening scene Mr. Sable, an undertaker, has trained his flock of ravens so effectively that a gravedigger, unable to secure easily the ring from a dead man's hand, has 'brought the finger and all,' and Sable himself announces that 'our friend . . . Dr. Passeport, with the powder, has promised me six or seven funerals this week.' There is rough humour in the scene (IV, 3) where Lord Hardy reviews a regiment as ragged as Falstaff's, and Kate Matchlock recounts matrimonial vicissitudes which surpass those of

1 Mr. Steele's Apology for Himself and his Writings, 1714, p. 80. 
the Wife of Bath. There is the extravagance of farce, too, in the scene $(V, 3)$ where the widow who asks, 'Do you think there are really people sorry for their husbands ?' apostrophizes her dead squirrel in blank verse of dubious rhythm, while Tattleaid weeps sympathetically, and then laughs at her sallies of wit, in imminent danger of swallowing a mouthful of pins.

Yet, if insincerity in grief is painted in high colours, there are not wanting portraits of virtue in Lady Harriot and Mr. Trusty, the honest steward. ${ }^{1}$ Furthermore, the play bears evidence of the vein of moral sentiment which Steele later developed more definitely. Mr. Campley, whose ardent phrases of passion for Lady Harriot Steele himself censured in The Spectator (No. 5I), is reproved by Lord Hardy, who expects his 'felicity from Lady Sharlot, in her friendship, her constancy, her piety, her household cares, her maternal tenderness' (II, I). When the lovers are united at the end, the apparition of Lady Sharlot from a coffin startles Lord Hardy into raptures, if not of genuine blank verse, at least of capitalized prose. Lady Sharlot responds in kind:

How sweet applause is from an honest tongue!

Thou lov'st my mind - hast well affection placed;

In what, nor time, nor age, nor care, nor want can alter.

Pure, I approach thee; nor did I with empty shows, Gorgeous attire, or studied negligence, Or song, or dance, or ball, allure thy soul;

1 'Mr. Trusty is the earliest example of a type which became familiar to the stage and of which Sheridan's Rowley is the bestknown specimen.' Ward, III, 494. 
Nor want, or fear, such arts to keep or lose it: Nor now with fond reluctance doubt to enter My spacious, bright abode, this gallant heart.

As she appropriately 'Reclines on Hardy,' the 'sentimental Muse' seems already mounting toward that bad eminence from which Sheridan later sought to dethrone her. Lord Brompton, too, delivers to his son a moral harangue on the duties of British peers, in blank verse that limps perceptibly. Comedy slinks to the wings, while morality holds the centre of the stage, till Lord Brompton, with a belated sense of the exigencies of comedy, drops from verse to prose with a 'Not but I intend your nuptials as soon as possible, to draw entails and settlements.' The Epilogue, however, reverts to the author's moral purpose - 'He'd not aim to please only, but inspire' and declares that 'Courage is brutal, if untouched with love.' If the success of The Funeral is to be attributed to the comic elements, its historical importance lies chiefly in its introduction of conscious morality and sentiment.

The Lying Lover, or The Ladies' Friendship (1703), strikes more firmly the notes of morality and sentiment already sounded in The Funeral. A passage in his $A$ pology, ${ }^{1}$ in which Steele declares himself 'a great Admirer' of Jeremy Collier's work, says that he took it into his head 'to write a Comedy in the Severity he [Collier] required,' and adds : 'I have been a Martyr and Confessor for the Church; for this Play was damn'd for its Piety.' Dedication, Preface, and Prologue alike testify to the deliberate moral purpose. 
In the first, he states that 'The design of it is to banish out of conversation all entertainment which does not proceed from simplicity of mind, good-nature, friendship, and honour'; in the second, he confesses 'an honest ambition to attempt a Comedy which might be no improper entertainment in a Christian commonwealth'; and in the third, he suggests that he 'treads the stage With just regard to a reforming age.' More significant, however, than this distinct moral purpose is the development of sentiment in comedy. Dr. Ward ${ }^{1}$ writes, "The serious portion of the plot of The Lying Lover . . . renders this play remarkable as the first instance of Sentimental Comedy proper.' Following the tentative essays in The Funeral, this portion is largely cast in the form of blank verse.

Perhaps the deepest significance of The Lying Lover is the proof it affords that sentiment was essentially a link between comedy and tragedy. The Preface remarks that Young Bookwit, the 'Lying Lover,' after prodigal waste of his opportunities, 'in the fifth Act awakes from his debauch, with the compunction and remorse which is suitable to a man's finding himself in a gaol for the death of his friend, without his knowing why. The anguish he there expresses, and the mutual sorrow between an only child and a tender father in that distress, are, perhaps, an injury to the rules of comedy, but I am sure they are a justice to those of morality. And passages of such a nature being so frequently applauded on the stage, it is high time that we should no longer draw occasions of mirth from those images which the religion of our 
country tells us we ought to tremble at with horror.' Equally significant is the Epilogue:

Our too advent'rous author soared to-night

Above the little praise, mirth to excite,

And chose with pity to chastise delight.

For laughter's a distorted passion. ...

While generous pity of a painted woe

Makes us ourselves both more approve and know.

In thus deliberately appealing to pity instead of laughter, sentimental comedy, in its very inception, links itself with the tragedy of Otway and Southerne. Henceforward, to adapt the words of Sir Fretful Plagiary, the writer of sentimental comedy 'might take out some of the best things in tragedy, and put them into his own comedy.' A wide gulf yawns between the conception of comedy as 'Laughter holding both his sides' and Steele's idea that 'laughter's a distorted passion.' Already Thalia is beginning to lose her smile under the borrowed mask of her tragic sister.

Steele could have little foreseen the devastating spread of those fires of revolution which he had helped to kindle. If the sentimentalized morality of the last act caused the play to be 'damned for its piety,' the earlier acts show that the author by no means abandoned wholly the usual methods of comedy. The scene (III, I) where the rivals, Penelope and Victoria, misuse patch and powder to disfigure each other's charms has the piquant touch of Restoration light comedy. Even the introduction of the hero to Newgate prison does not forbid a comic scene $(I V, 4)$ 
where he is hailed by the 'crowd of gaol-birds' as a hero, since he is thought to have killed his man. In borrowing from Corneille, Steele followed a familiar practice of English playwrights. The significance of The Lying Lover, however, rests not in its indebtedness to Continental sources, but in its radical departures into new fields.

In The Lying Lover, Young Bookwit had pronounced himself (III, 2) 'the founder of accomplished fools, of which I'll institute an order.' This order Steele seems to have instituted in The Tender Husband, or The Accomplished Fools (I705). For the main title, and something of the treatment of the theme, he may have taken suggestions from Cibber's Careless Husband. In dedicating this play to Addison, who wrote the Prologue, Steele says that he would not offer it as a memorial of their friendship 'had I not been very careful to avoid everything that might look ill-natured, immoral, or prejudicial to what the better part of mankind hold sacred and honourable.' Yet the opening scene develops Clerimont's repellant scheme of testing his wife by disguising his mistress, Fainlove, in man's attire, and the scene $(\mathrm{V}, \mathrm{I})$ where Clerimont interrupts their assignation approaches too closely the dangerous path of Restoration comedy. It may be said that Steele reunites husband and wife in the recognition that married happiness rests on constant love, but it is a doubtful ethical standard that permits the erring husband to pose as tenderly magnanimous. When he condescendingly forgives his wife with the words, 'And now I have shown you your error, I'm in so good humour as to repeat you a couplet on the 
occasion,' one would gladly substitute 'Forgiveness to the injured does belong.'

Far more interesting is that part of the play which concerns Biddy Tipkin and her cousin Humphry Gubbin - ancestors, in some sense, of Sheridan's Lydia Languish ${ }^{1}$ and Goldsmith's Tony Lumpkin. Biddy Tipkin, who 'has spent all her solitude in reading romances' and has renamed herself 'Parthenissa,' is steeped in French and English romances as thoroughly as is Lydia Languish in the sentimental novels of the circulating library. Biddy's romantic 'humour' gives rise to excellent comic scenes - with Clerimont, who humours her with the fantastic language of chivalry, and with her country bumpkin cousin, who submits his intended bride to scrutiny, 'as not caring to buy a pig in a poke.' The scene (III, 2) where Biddy and her cousin agree to disagree, and the Aunt is led to think 'they are come to promises and protestations,' is closely akin to Goldsmith's scene between Tony Lumpkin and Miss Neville where Mrs. Hardcastle imagines they are billing and cooing. It is somewhat remarkable that Goldsmith and Sheridan who led so powerfully the revolt against sentimental comedy borrowed from Steele. Fielding, too, possibly found suggestions for Squire Western in Sir Harry Gubbin. On the other hand, Steele owed somewhat to Molière, to Cibber, and to Addison, ${ }^{2}$ while the passage $(\mathrm{V}, \mathbf{2})$ in which Tipkin insists on being written down a rascal is obviously reminiscent of Dogberry. Viewed as a

1 For more detailed comparison, see the present writer's Major Dramas of Richard Brinsley Sheridan, Introduction, liv-lvi.

2 See Steele's acknowledgement in The Spectator, No. 555. 
whole, The Tender Husband is perhaps Steele's most genuine comedy.

During the period of The Tatler, The Spectator, and The Guardian, Steele turned from drama to essay. The Conscious Lovers ( 1722 ) resumes the vein of sentimental comedy. The attacks upon it of Dennis and other pamphleteers may have increased its success. Revivals of it were frequent for some forty years, and it was acted at times in the first decades of the next century. Definitely directed against duelling, it is devoted so seriously to the cause of virtue that the Preface declares some incidents 'are esteemed by some people no subjects of comedy.' The distresses of the sentimental Indiana drew tears from General Churchill. ${ }^{1}$ Fielding's Parson Adams 'never heard of any plays fit for a Christian to read, but Cato and The Conscious Lovers' and owned that 'in the latter there are some things almost solemn enough for a sermon.' ' Welsted's Prologue declares that Steele 'By new and desperate rules resolved to write,' and sought to 'please by wit that scorns the aids of vice.' The audience is invoked 'with breeding to refine the age, To chasten wit, and moralise the stage.' Fortunately, at Colley Cibber's suggestion, Steele admitted a larger comic element than he had at first allowed himself. The excellent scene where Tom recalls to Phillis his torments of love while he washed the outside of a window which she was cleaning inside is a delightful bit of foolery - an uncon-

'See Steele's Preface, and G. A. Aitken's footnote, Mermaid edition of Steele, p. 270.

2 Joseph Andrews, Book III, Chapter XI (end). 
scious burlesque, one is tempted to suggest, of the sentiment of the conscious lovers. Unhappily such byplay only partially relieves the essentially sentimental strain. More prominent are the virtuous loves of Bevil and Indiana, the moral heroics which tend to convert Bevil from hero to prig, and the tragic heartrendings of Indiana before her restoration to her long-lost father. The dialogue responds to the sentimental strain. 'If pleasure,' says Bevil (II, 2), 'be worth purchasing, how great a pleasure is it to him, who has a true taste of life, to ease an aching heart; to see the human countenance lighted up into smiles of joy, on the receipt of a bit of ore which is superfluous and otherwise useless in a man's own pocket?' Bevil ushers the music-master to the door with less of the instinctive courtesy of the gentleman than the complaisant condescension of the conscious prig, declaring 'we ought to do something more than barely gratify them for what they do at our command, only because their fortune is below us.' To this Indiana responds with 'a smile of approbation' and the sentiment that she 'cannot but think it the distinguishing part of a gentleman to make his superiority of fortune as easy to his inferiors as he can.' Many of the scenes conclude with moral tags in verse. Already the habit of moral aphorism had fastened itself on comedy, a habit that was to develop to great extremes before it lost its charm in the mouth of the hypocrite, Joseph Surface.

In the history of English drama, Richard Steele attains a prominence disproportionate to his actual dramatic merits. Without the dramatic power of 
many of his Restoration predecessors, and without the insight that makes morality the ally, rather than the conscious master, of dramatic art, Steele at least perceived that the art that holds the mirror up to nature cannot be divorced from the greatest law of nature. Despite both his own ethical shortcomings and the excessive zeal that turned morality into moralizing, he gave powerful and salutary aid to a reform of vital necessity to drama. Yet, if Steele led the way to moral reform, he also led the way unconsciously to dramatic decay. Sentiment becomes in inferior hands sentimentality. The appeal of Steele's sentimental comedy to the emotion of pity became with inferior playwrights a false emotional motive. The doctrine that 'laughter's a distorted passion' led comedy to substitute tears for mirth. The moral reform of English drama was won at the expense of almost half a century during which-Comedy bowed her head in the presence of Sentimentality. Restoration comedy has long worn the title of 'artificial,' but in another sense, it was an equally artificial comedy that in the first half of the eighteenth century. offered its sacrifices to 'The Goddess of the woeful countenance - the Sentimental Muse.' 


\section{CHAPTER $\mathrm{X}$}

SOME ASPECTS OF QUEEN ANNE DRAMA ${ }^{1}$

As the retirement of Congreve largely eclipsed the gaiety of comedy, the death of Dryden emphasized the close of Restoration tragedy. The fine frenzy of Lee had burned itself out in gusts of insanity; 'tender Otway' had long since met his tragic end. Neither the theatrical declamation of Banks nor the sentimental pathos of Southerne could achieve an All for Love or a Venice Preserved. At the time of Collier's invective, an enfeebled tragedy held the stage. The brunt of his attack had fallen naturally upon comedy. With the exception of its coarsely comic prologues and epilogues, Restoration tragedy had done violence to nature rather than to morality. Its very unreality had removed it from the fashionable vice which had been too faithfully reproduced in contemporary comedy. The heroic drama had torn passion to tatters, yet there had remained shreds of heroic valour and love. With the awakening tendency to reform the stage, tragedy became more moralized and more sentimentalized. The titles of some of the tragedies of 1698 distinctly suggest a recurrence to themes of heroic drama - Victorious Love; The Fatal Discovery, or Love in Ruins; Heroick Love; Beauty

${ }^{1}$ The present chapter is not confined rigidly to the exact limits of Queen Anne's reign, I702-1 714. 
in Distress; Queen Catharine, or The Ruins of Love. Though Mrs. Pix's Queen Catharine has English characters, most of the tragedies of the year give to their themes of love and valour a foreign setting. Crowne's Caligula reverts even to the use of rhyme. Yet not love itself, but the ghost of love moves among the ruins of heroic sentiment. In vain did George Granville proclaim the heroine of his Heroick Love

The brightest Pattern of Heroick Love

And perfect Virtue, that the World e're knew. $(\mathrm{V}, 2)$

In the dire distress of comedy, the writers of tragedy may perhaps have seen an opportunity which they lacked ability to grasp. It is dangerous to generalize from imperfect data, but Genest's lists of plays produced at the various London theatres seem to show a preponderance of comedies for the years 1696 and r697, and of tragedies for the years 1698 and 1699 . Yet the decline of comedy, owing partly to dearth of comic genius, partly to its more rigorous restriction, and partly to its increasing substitution of sentiment and pathetic appeal instead of mirth, cannot be said to be accompanied by a corresponding rise in tragedy. If the waters of tragedy broaden, they do not run deep. Neither the advent of female dramatists like Mrs. Manley, Mrs. Pix, and Catharine Cockburn (later Mrs. Trotter), nor the excursions of critics like Charles Gildon and John Dennis in the field of drama, could vitalize tragedy. Alike unavailing were Dennis's attempts, in 1699 , to borrow tragic themes from Tasso in Rinaldo and Armida, and from Euripides in Iphigenia. 
While the stage was sore beset by Collier and other foes from without, it had to struggle against enemies from within. Attention has already been directed to the tangible effect upon drama of the elaboration of scenery and stage mechanism and of the operatic accessories of music and dancing. The last decades of the seventeenth century show many proofs of the continued force of such influences. Dorset Gardens, in Dryden's words, 'the gaudy house with scenes,' became increasingly a home for spectacle. The Prologue to Farquhar's Constant Couple (I699) laments:

Ah, friends! Poor Dorset-Garden house is gone;

Our merry meetings there are all undone:

Quite lost to us, sure for some strange misdeeds, That strong dog Samson's pull'd it o'er our heads.

Under Christopher Rich its 'gay shows' were devoted frequently to feats of acrobats and exhibitions of animals. Cibber recalls Rich's project of introducing 'an extraordinary large Elephant' and his reluctant abandonment of 'so hopeful a Prospect of making the Receipts of the Stage run higher than all the Wit and Force of the best Writers had ever yet rais'd them to.'1

Dorset Gardens Theatre was not alone in catering to the popular taste for 'such conceits as clownage keeps in pay.' The Prologue to Steele's Funeral (I7OI) begins thus :

Nature's deserted, and dramatic art, To dazzle now the eye, has left the heart; Gay lights and dresses, long extended scenes, Demons and angels moving in machines, 
All that can now, or please, or fright the fair,

May be performed without a writer's care,

And is the skill of carpenter, not player.

Old Shakespeare's days could not thus far advance;

But what's his buskin to our ladder dance?

A generation earlier Dryden had deplored the advent of a 'French troop' that 'left their itch of novelty behind.' His forebodings were amply justified. Downes says in his Roscius Anglicanus (I 708) ${ }^{1}$ : 'In the space of Ten Years past, Mr. Betterton [then manager of Lincoln's Inn Fields Theatre] to gratify the desires and Fancies of the Nobility and Gentry; procur'd from Abroad the best Dances and Singers, as, Monsieur L'Abbe, Madam Sublini [Subligny], Monsieur Balon, Margarita Delpine, Maria Gallia and divers others; who being Exorbitantly Expensive, produc'd small Profit to him and his Company, but vast Gain to themselves.' To the same effect runs the testimony of Colley Cibber and Charles Gildon, ${ }^{2}$ while Rowe, in the Epilogue to The Ambitious Step-Mother (I700), produced at Lincoln's Inn Fields Theatre, declares:

Show but a Mimick Ape, or French buffoon, You to the other House in Shoals are gone, And leave us here to tune our Crowds alone. Must Shakespear, Fletcher, and laborious Ben, Be left for Scaramouch and Harlequin?

Referring to a somewhat later date, Colley Cibber says that 'the Patentee of Drury-Lane [Rich] went on in his usual Method of paying extraordinary Prices

2 p. 46.

${ }^{2}$ A pology, I, 316-317. Gildon, A Comparison between the Two Stages, 1702, p. 49: 'The Town ran mad to see him' [Balon]. 
to Singers, Dancers, and other exotick Performers, which were as constantly deducted out of the sinking Sallaries of his Actors. . . . For it seems he had not purchas'd his Share of the Patent to mend the Stage, but to make Money of it. . . . His point was to please the Majority, who could more easily comprehend any thing they saw than the daintiest things that could be said to them.' ${ }^{1}$ Yet even Cibber, whose $A$ pology bristles in defence of regular drama, and who once refused to appear on the stage on the same day with 'a Set of Rope-dancers,' ' ${ }^{2}$ confesses that, as a manager, he compromised his convictions, 'and had not Virtue enough to starve by opposing a Multitude that would have been too hard for me.' ${ }^{3}$

Among the various stage diversions which thus challenged regular drama in the competition for popular favour none was more conspicuous, in the first decade of the eighteenth century, than Italian opera. Some account has been given previously of D'Avenant's introduction of English opera and of the subsequent development of what Cibber describes ${ }^{4}$ as 'a new Species of Plays, since call'd Dramatick Opera's, of which kind were the Tempest, Psyche, Circe, and others, all set off with the most expensive Decorations of Scenes and Habits, with the best Voices and Dancers.' In his Prologue spoken at the Opening of the Nerw House (I674), Dryden declared it folly

To build a playhouse while you throw down plays;

While scenes, machines, and empty operas reign. 
Yet Dryden himself, in 1685, produced his opera Albion and Albanius, and in the Preface defined opera as 'a poetical tale, or fiction, represented by vocal and instrumental music, adorned with scenes, machines, and dancing.' The English stage had, therefore, been familiar with some forms of opera long before the appearance of Arsinoë (I 705) which Addison calls 'the first opera that gave us a taste of Italian music.' 1 Cibber pictures ${ }^{2}$ unsparingly the advent of Italian opera in England 'in as rude a disguise and unlike it self as possible; in a lame, hobling Translation into our own Language, with false Quantities, or Metre out of Measure to its original Notes, sung by our own unskilful Voices, with Graces misapply'd to almost every Sentiment, and with Action lifeless and unmeaning through every Character.' Native English writers vigorously denounced the foreign invader. In the Epilogue to The Tender Busband (1705), Steele bade Britons

From foreign insult save this English stage.

No more th' Italian squalling tribe admit,

In tongues unknown.

John Dennis, in An Essay on the Opera's After the Italian Manner, Which are about to be Establish'd on the English Stage (r 706), after pronouncing Italian opera 'monstruous,' declares ${ }^{3}$ that in Italy, however, it is 'a beautiful harmonious Monster, but here in England 'tis an ugly howling one.' Addison, whose later strictures on

1 The Spectator, No. 18. This entire paper, together with Nos. 5, 13, and 29, should be consulted for Addison's views on opera.

A Apology, I, 324 .

p. 14. 
Italian opera include an attack on the mongrel blending of English words with the Italian recitativo style, ${ }^{1}$ seemingly attempted, with the aid of the composer Clayton, to produce in Rosamond (I707) a native English opera. ${ }^{2}$ Yet dramatists like Vanbrugh and Congreve recognized, as managers, the 'prevailing Novelty' by opening 'their new Hay-Market Theatre with a translated Opera to Italian Musick, called the Triumph of Love' 3 (I705). Of three distinguished operatic singers, Valentini, Nicolini, and Mrs. Tofts, Colley Cibber himself says ${ }^{4}$ that 'three such excellent Performers in the same kind of Entertainment at once, England till this Time had never seen.' The main reliance of Rich during the Drury Lane season of I 706I707 was opera. Rinaldo ( I 7 I I), the first of Handel's numerous operas for the English stage, was a popular success. Doubtless the effect of opera upon the drama is to be measured not merely by the extent to which it usurped the place of drama on the public stage, but also by the inevitable tendencies of its theatrical and spectacular features toward the improbable and the unnatural in dramatic representation.

Notwithstanding the powerful forces that thus threatened regular drama, its cause was by no means desperate. During the first decade of the eighteenth century, Elizabethan and Restoration plays were con-

1 The Spectator, No. 29.

2 'It appears to have been intended as a kind of protest against the librettos of operas written to suit the English performers, who helped out the arias and duets sung by the Italians in their native tongue.' Ward, III, 323, footnote.

A $A$ pology, I, 325.

Ibid., II, 55 . 
stantly reproduced. Tragedies of Shakespeare - some of them, unfortunately, in their Restoration perversions - tragi-comedies of Beaumont and Fletcher, heroic dramas of Dryden, and many plays of Otway, Lee, Banks, Southerne, and Congreve may fairly be regarded as stock plays of the period. Nor was the theatre forced to draw its vitality wholly from the strength of the past. Farquhar, Cibber, and Steele won success in comedy. Tragedy, which seemed for a time to have fallen upon evil days, found some encouragement in the advent of a new dramatist of real ability.

On the death of his father, a London barrister, Nicholas Rowe (r674-I718) turned from the uncongenial pursuit of law to drama. The Ambitious Step-Mother (1 700) gives to court intrigues an Oriental setting, somewhat in the fashion of heroic tragedy, but with a pathetic appeal in the self-sacrifice of Cleone which recalls Otway. Betterton, Mrs. Bracegirdle, and Mrs. Barry gave the play much of its stage success. Tamerlane (I 702), the tragedy on which, it was said, ${ }^{1}$ the author 'valu'd himself most,' was helped by its political intention. The hero was drawn to suggest William III, and his rival, Bajazet, to suggest Louis XIV. Until I81 $_{5}$, it was played annually at Drury Lane on 5 November, the anniversary of the landing of William III and of the Gunpowder Plot. The moralized sentiments of the hero show the stirrings of sentimental drama.

The Fair Penitent (1 703), a sentimental adaptation

1 James Welwood, Preface, p. xl, to Lucan's Pharsalia; Translated into English Verse, by Nicholas Rowe, 1720 edition. 
from The Fatal Dowry by Massinger and Field, was one of the most successful tragedies of the eighteenth century. ${ }^{1}$ Doctor Johnson said," 'There is scarcely any work of any poet at once so interesting by the fable and so delightful by the language.' Like Otway's Orphan and Southerne's Fatal Marriage, The Fair Penitent is essentially a domestic tragedy. The Prologue shows that Rowe was deliberate in his choice of theme :

Long has the fate of kings and empires been The common bus'ness of the tragick scene, As if misfortune made the throne her seat, And none cou'd be unhappy but the great.

Stories like these with wonder we may hear, But far remote, and in a higher sphere, We ne'er can pity what we ne'er can share.

Therefore an humbler theme our author chose, A melancholy tale of private woes:

No princes here lost royalty bemoan, But you shall meet with sorrows like your own.

Tragedy becomes not merely domestic, but moralized. Horatio is full of wise saws such as 'To be good is to be happy,' and 'Guilt is the source of sorrow.' ${ }^{3}$ In a concluding speech he points the moral in a rhymed tag which may be compared with the last lines in Steele's contemporary comedy, The Lying Lover (I 703) :

1 Genest cites more than a score of revivals up to 1824 .

2 Lives of the English Poets, Hill edition, I905, II, 67.

III, I, 98, 100. 
By such examples are we taught to prove, The sorrows that attend unlawful love;

Death, or some worse misfortunes, soon divide The injur'd bridegroom from his guilty bride:

If you would have the nuptial union last, Let virtue be the bond that ties it fast.

Compared with its Elizabethan model, The Fatal Dowry, by Massinger and Field, The Fair Penitent is less free and varied. With a consciousness of French restrictions, Rowe reduces the characters to eight, condenses the time of action, and simplifies the action. This simplification, indeed, is carried too far. Rowe begins with the end of Massinger's second act, and has accordingly to give in the first part of the play too much exposition of matter which Massinger presents actually. In Massinger, the hero dominates; in Rowe, the villain. Massinger's heroine, already married, is seduced through the contrivance of a servingwoman, and her repentance is that of a contrite heart. Calista's hot passion accounts for her own downfall, and she yields to a disgraceful marriage later. Nor does her penitence begin until she is found out. However 'fair,' she is not really 'penitent.' The father in Massinger's play is tender and full of anguish; Calista's parent is a Roman father. The freedom and vitality of the Elizabethan play are lacking in Rowe's work.

The Prologue sets forth still another principle of Rowe's creed :

Who writes shou'd still let nature be his care, Mix shades with lights, and not paint all things fair, But shew you men and women as they are. 
It is somewhat curious that Rowe, whose Lothario and Calista evidently influenced Richardson's Lovelace and Clarissa, should be here setting forth a creed that would suit Thackeray better than Richardson. To a certain extent Rowe may be said to have succeeded in his attempt to blend shade with light. Altamont and Horatio, though somewhat icily regular, are at least not faultily faultless. Lothario has the courage of his vices and evidently some personal magnetism. The 'haughty, gallant, gay Lothario' - as Calista calls him in the fifth act - has achieved the rare distinction of a place among those characters whose mere names connote the characterizing epithet. Even in the last act, when the villain is dead, his body dominates the sinister scene. The 'Scene is a room hung with black; on one side Lothario's body on a bier; on the other a table with a skull and other bones, a book, and a lamp on it. Calista is discover'd on a couch in black, her hair hanging loose and disordered : after musick and a song, she rises and comes forward.' It is a scene that points backward to the Elizabethans, and forward to Joanna Baillie's imitations a century later.

In the next years Rowe's dramatic work declines abruptly. In The Biter (I704), he encountered his only real dramatic failure. Ulysses (I705), ${ }^{1}$ a classical tragedy, whose story Genest conservatively pronounces 'less interesting' than Homer, and The Royal Convert (I707), based on Hengist and early British history, abandon the Elizabethan type. In

${ }^{1}$ This play has recently been assigned to 1706 , but Genest gives the first performance, 23 November, 1705. 
I 709, Rowe published his six-volume edition of Shakespeare, with a biography based partly on material collected by Betterton, with lists of the dramatis persone and indications of exits and entrances, and with some revision of the text in spelling and punctuation. It was the first critical edition of Shakespeare.

The study of Shakespeare directly influenced Rowe's subsequent dramatic career, In Jane Shore (I II4) and Lady Jane Gray ( I 7 I 5), he strove to follow Shakespeare. The first is professedly 'Written in Imitation of Shakespear's Style.' In the Prologue to The Ambitious Step-Mother he had already delivered the curious verdict that Shakespeare excelled in male characters only :

Shakespear, whose Genius to it self a Law, Could Men in every Height of Nature draw, And copy'd all but Women that he saw.

As Dryden had hoped to refine Shakespeare's language, Rowe seemingly thought to supply his deficiency in heroines. At least, his last dramas are, to borrow the phrase in the Epilogue to Jane Shore, 'She-tragedies.' His imitation of Shakespeare has been regarded by some as merely nominal. Yet most of the male characters of Jane Shore figure in Richard III, and Gloster himself, though reduced by Rowe to a subordinate position, shows signs of Shakespeare's influence.

In comparison with The Fair Penitent, Jane Shore shows dramatic progress. The earlier tragedy depended largely on scenic background and the acces- 
sories of fertile invention. In Jane Shore the heroine is a true penitent, and arouses more genuine pity. The appeal, as in Otway, is largely feminine, and sometimes Rowe descends to mere tameness. Yet the hallmark of his tragedies is refinement. The grossness of the elder dramatists gives way before an impulse of higher tone. His verse may appeal rather to the ear than to the heart, his sentiment may be surcharged with moralizing, but if he lacks masculine vigour he is at least free from animal brutality.

Rowe is the dramatist of repentant love. Admitting no comic relief, and ruling himself largely in accordance with Gallic restraint and convention, he follows to a large extent the French traditions. But in professing to imitate Shakespeare, and in certainly following Otway, he links to English drama. Despite his laureateship, he lacked genuine poetic impulse. He could touch pity, but not with the fervour of poetic passion. As a dramatist he lacked differentiation of character. Though Richard III does not have the characteristic Shakespearean development of minor characters, it is only necessary to compare the historical characters in Jane Shore with those in Richard III to see how Rowe omits the details which are the charm, not merely, as Macaulay says, of biography, but also of drama. With all his defects, Rowe holds a place of his own in the history of English tragedy. His most important plays maintained their vitality through the whole of the eighteenth century, and well into the nineteenth. Garrick, Charles Kemble, Mrs. Siddons, Mrs. Yates, Kean, and Macready are but some of those who won suc- 
cess in his dramas. The best of them were translated into French, and published in many English editions. Even to-day, when his tragedies are no longer familiar to playgoers, the character of Lothario has not lost its individuality.

The Elizabethan tendencies of Rowe's later plays should not be mistaken for evidence of the general state of drama. The sympathies of Queen Anne critics were habitually with classical precept and practice. The powerful influence of Addison was felt in the direction of dramatic rule and regularity. Rowe himself, in restricting characters and action and excluding comedy, follows largely Continental examples. The direct influence of Racine upon English tragedy appears in Edmund Smith's Phadra and Hippolytus (I 707), ${ }^{1}$ modelled on Phèdre, and Ambrose Philips's Distrest Mother (I I I 2), a slightly modified translation of Andromaque. Addison wrote a prologue for the first and an epilogue for the second, while Steele's comments in The Spectator increased the vogue of The Distrest Mother. Philips doubtless owed much of his initial success to the popular tone of moralizing sentiment, but in following Racine he contributed to the strengthening of classical influences.

A conspicuous triumph for classical drama was won by JoSEPH Addison (1672-1719) in Cato (I 7 13). Like Dryden, Addison had critical taste rather than natural dramatic instinct. Like both Dryden and Steele, he felt the force of the theatrical tide. No stronger evidence of the continued hold of the drama need be

1 The date, 1706, recently given by several critics, seems to overlook Genest, II, 368, who says, 21 April, 1707. 
sought than in the long line of masters of other forms of literature who have become servants for a time of drama. Perhaps only the Elizabethan age found its natural and characteristic expression in drama. Yet the critical essayists of the Queen Anne period and the creative poets of the Victorian alike felt the same magnet. Addison's opera, Rosamond, and his feeble comedy, The Drummer (I 7I6), though failures, show his attempts to win the applause of the theatre. Not even the signal and continued stage success of Cato can disguise the fact that Addison's genius was non-dramatic. Addison was the Spectator who saw the outside rather than the heart. $\mathrm{He}$ is without the dramatist's impulse to animate character into action. Sir Roger de Coverley might possibly have been the hero of a character novel, but hardly of a drama. The stage triumph of Cato may have seemed an effective answer to Pope's advice to Addison to have the play printed rather than acted; but Pope's judgment was wiser perhaps than he knew.

Much of Addison's unquestionable influence upon English drama must be sought in his critical work. Though in at least one striking passage ${ }^{1}$ he puts Shakespeare's genius above artificial restraints, Addison was at heart a confirmed classicist. He had the French fondness for the unities, the distaste for tragicomedy, ${ }^{2}$ the dislike not merely of stage violence but of excess of emotional appeal. ${ }^{3}$ Yet in banishing excess of emotion, Addison came dangerously near

1 The Spectator, No. 592.

2 Ibid., No. 40.

Ibid., No. 44 . 
banishing emotion itself. He saw the absurdities of Nicolini and the Lion, and of 'painted dragons spitting wildfire, enchanted chariots drawn by Flanders mares, and real cascades in artificial landskips '1 in Handel's Rinaldo, but not the artificiality of his own Romans. Rant he calls one of 'the blemishes, or rather the false beauties, of our English tragedy.' 2 Yet Doctor Johnson said ${ }^{3}$ that the success of Cato induced 'the use of dialogue too declamatory, of unaffecting elegance, and chill philosophy.'

Cato is an appeal to the reason. Cato and his companions, like Plato, reason well. But they remain abstractions of thought, rather than living personalities. Cato has the chill of a statue, a Galatea without the touch of life that permits descent from the pedestal. As Doctor Johnson says, ${ }^{4}$ 'It is rather a poem in dialogue than a drama, rather a succession of just sentiments in elegant language than a representation of natural affections, or of any state probable or possible in human life.... The events are expected without solicitude, and are remembered without joy or sorrow.'

Despite Pope's fear that Cato was a closet rather than an acting drama, circumstances combined to make it a great success. In Doctor Johnson's familiar words, "The Whigs applauded every line in which Liberty was mentioned, as a satire on the Tories; and the Tories echoed every clap, to shew that the satire was unfelt.' Yet its success did not rest wholly

1 The Spectator, No. 5.

2 Ibid., No. 40.

'Lives of the English Poets, Hill edition, 1905, II, I33.

- Ibid., II, I32.

Ibid., II, 100-101. 
on local politics. It was translated into Italian, French, and German. Voltaire hailed it as a masterpiece, and called its author 'The first English Writer who compos'd a regular Tragedy [tragédie raisonnable] and infus'd a Spirit of Elegance thro' every Part of it.' ${ }^{1}$ The classicists had, indeed, scant reason for complaint. The action takes place in 'a large Hall in the Governor's Palace of Utica,' the time is confined to 'the great, th' important Day; big with the Fate Of Cato and of Rome,' and the interest centres in Cato. Death occurs off the stage in the case of Marcus, while it is again off the stage that Cato runs on his sword, though he is brought in dying. There are feeble attempts at local colour, but Addison's Numidian touches suggest no more than Dryden's faint Spanish and Oriental settings. Everywhere the chill of death seems to rest. The characters are benumbed in action and constrained in expression. Even the passages that are commonplaces of quotation suffer from want of vital feeling. It is a striking commentary on the artificiality of the Queen Anne age that the cold formality of Cato kindled the fires of party spirit.

In the Prologue, Pope had sought to rally support for the native English drama :

Our Scene precariously subsists too long On French Translation, and Italian Song.

Dare to have Sense your selves; Assert the Stage;

Be justly warm'd with your own Native Rage.

Yet Cato in reality chilled the 'native rage' of English tragedy with the classical restraints of Continental drama.

${ }^{1}$ Letters concerning the English Nation (translated), 1733, p. 178. 


\section{CHAPTER XI}

\section{PANTOMIME AND BALLAD OPERA}

Cato was a temporary triumph, not a permanent victory, for the cause of classical drama. The appearance of Rowe's Jane Shore, in the following year, showed that the Elizabethan tradition had not been forgotten. Year after year, the chief Shakespearean tragedies continued to hold the boards, and revivals of other Elizabethan plays were frequent. During the Drury Lane winter season of $\mathrm{I}_{7} \mathrm{I}_{3}-\mathrm{I}_{7} \mathrm{I}_{4}$ there were productions of The Tempest and of Henry IV, Part I, of Ben Jonson's Volpone, Bartholomew Fair, The Silent Woman, and The Alchemist, of Beaumont and Fletcher's Philaster, and of Fletcher's Humorous Lieutenant. Yet, if the French classical influence upon English drama of the period has often been exaggerated, there is no reason for underestimating its real importance. The great success of Philips in The Distrest Mother stimulated other translations of Racine and of Corneille. Among them were Colley Cibber's Heroic Daughter, or Ximena (I 7 I2), an adaptation of Le Cid, Cinna's Conspiracy (I7I3), a free rendering of Corneille's Cinna, and versions of Racine's Iphigénie. Thus the long strife between French theory and English practice was maintained on the English stage with almost incessant fluctuations in the tide of battle. In point of fact, the actual dramatic product 
was often an unconscious compromise between two extremes. Rowe, who confessedly imitated Shakespeare's style, had the French dislike for tragi-comedy and usually observed the French restraint as to scope of action and number of characters. Translators and followers of French dramatic models did not escape the influence of English sentimental drama. Even the most conspicuous classical triumphs of Philips and Addison were founded on the distresses of the heroine and the moralized sentiments of the hero.

In the first decade of the eighteenth century, regular drama had found a formidable rival in Italian opera. With the second decade, there came into prominence a still more powerful rival-English pantomime. The traditional account of its origin should not, of course, be held to imply that English pantomime sprang full-fledged from the head of JoHN RICH (I682 ?I76r). Pantomimic action of a sort had long been known on the English stage. The 'dumb-shows' which Hamlet found 'inexplicable' had been introduced in Gorboduc, the first English tragedy. Masque, opera, and spectacle had, during the Restoration period, developed to a notable degree scenic and mechanical effects. Mrs. Behn had introduced a Harlequin in her Emperor of the Moon (I687). Yet, in the adaptation to his own purposes of earlier stage properties and devices and in the creation of his own novelties, John Rich is fairly entitled to credit for originality. Even if one were to accept Colley Cibber's questionable ascription of the origin of pantomime to John Weaver's Drury Lane production of The 
Loves of Mars and Venus (I716 or I717), ${ }^{1}$ Rich may be said to have formulated the popular type.

Cibber recounts ${ }^{2}$ how, when our 'English Musick had been so discountenanced since the Taste of Italian Operas prevail'd,' his company decided to exploit dancing, a feature that had been popular at the rival theatre. 'To give even Dancing therefore some Improvement, and to make it something more than Motion without Meaning, the Fable of Mars and Venus was form'd into a connected Presentation of Dances in Character, wherein the Passions were so happily expressed, and the whole Story so intelligibly told by a mute Narration of Gesture only, that even thinking Spectators allow'd it both a pleasing and a rational Entertainment. . . . From this original Hint then (but every way unequal to it) sprung forth that Succession of monstrous Medlies that have so long infested the Stage.' Reluctantly Cibber goes on to confess his own share in 'these Fooleries,' but adds : 'Notwithstanding, then, this our Compliance with the vulgar Taste, we generally made use of these Pantomimes but as Crutches to our weakest Plays: Nor were we so lost to all Sense of what was valuable as to dishonour our best Authors in such bad Company: We had still a due Respect to several select Plays that were able to be their own Support; and in which we found our constant Account, without painting and patching them out, like Prostitutes, with these Follies in fashion.'

1 The earlier date is claimed by Weaver. See his $B$ istory of the Mimes and Pantomimes, 1728, p. 46.

2 A pology, II, I79 ff. 
The obvious inference from Colley Cibber's account is that the 'original hint' for English pantomime is to be found in The Loves of Mars and Venus, John Weaver's Drury Lane entertainment. Weaver was a noted dancing master, who, according to Biographia Dramatica, 'also wrote several judicious books, which show that a head was not wanting to his heels.' Among half a dozen treatises concerned with the art of dancing is a work entitled The History of the Mimes and Pantomimes, ${ }^{1}$ which includes 'A List of the Modern Entertainments that have been Exhibited on the English Stage; either in Imitation of the Ancient Pantomimes, or after the Manner of the Modern Italians.' If his own testimony is to be accepted, he must be credited with a considerable part in the stage history of his day. He styles his Loves of Mars and Venus 'an Attempt in Imitation of the ancient Pantomimes, and the first of that kind that has appeared since the Time of the Roman Emperors.' Much earlier than this, however, was his production, in I702, of The Tavern Bilkers. This he terms 'the first Entertainment that appeared on the English Stage, where the Representation and Story was carried on by Dancing, Action and Motion only.' The various entertainments produced by Weaver seem, at least, forerunners of Rich's more conspicuous successes.

At all events, the essential credit - or discredit, as Cibber would have held it - for establishing English pantomime thoroughly in popular favour belongs to Rich. He had no more scruples than his father in

${ }^{1}$ Printed I728. The 'List' occupies pp. 43-56. For quotations, see pp. 45-46. 
complying with 'the vulgar taste.' Recognizing that his theatrical gift lay rather in mimicry than in spoken dialogue, he was clever enough to make capital out of the very limitation of his talent. Acting habitually under the name of 'Lun,' Rich made Harlequin an actual pantomimic part, but with Rich actions spoke louder than words. Of the general character of his pantomimes sufficient indication may be found in the prose of Thomas Davies and the verse of Pope. Davies, who credits Rich with the creation of pantomime, gives ${ }^{1}$ this description of it : 'It consisted of two parts, one serious, and the other comic: by the help of gay scenes, fine habits, grand dances, appropriated music, and other decorations, he exhibited a story from Ovid's Metamorphosis [sic], or some other fabulous writer. Between the pauses or acts of this serious representation, he interwove a comic fable, consisting chiefly of the courtship of Harlequin and Columbine, with a variety of surprising adventures and tricks, which were produced by the magic wand of Harlequin; such as the sudden transformation of palaces and temples to huts and cottages; of men and women into wheel-barrows and joint-stools; of trees turned to houses; colonades to beds of tulips; and mechanics shops into serpents and ostriches.' The familiar lines in Pope's Dunciad (iii, 233 ff.) may supplement this account :

[He] look'd, and saw a sable Sorc'rer rise, Swift to whose hand a winged volume flies: All sudden, Gorgons hiss, and Dragons glare. And ten-horn'd fiends and Giants rush to war.

1 Memoirs of the Life of David Garrick, 'New Edition,' 1780, I, 92. 
Hell rises, Heav'n descends, and dance on Earth, Gods, imps, and monsters, music, rage, and mirth, A fire, a jig, a battle, and a ball, Till one wide conflagration swallows all.

Thence a new world, to Nature's laws unknown, Breaks out refulgent, with a heav'n its own:

Another Cynthia her new journey runs, And other planets circle other suns.

The forests dance, the rivers upward rise, Whales sport in woods, and dolphins in the skies; And last, to give the whole creation grace, Lo! one vast Egg produces human race.

This last line is a definite allusion to Rich's famous trick of 'the hatching of Harlequin by the heat of the sun.' Jackson, in his History of the Scottish Stage, describes this 'master-piece in dumb-shew. From the first chipping of the egg, his receiving motion, his feeling the ground, his standing upright, to his quick Harlequin trip round the empty shell, through the whole progression, every limb had its tongue, and every motion a voice, which "spoke with most miraculous organ," to the understandings and sensations of the observers.'

The success of the pantomimes led the Patent Theatres to rival each other. In I723, Thurmond's elaborate Drury Lane pantomime, Harlequin $\mathrm{Dr}$. Faustus, was offset at Lincoln's Inn Fields by Rich's Necromancer, or the History of Dr. Faustus. The theatres advanced their prices on pantomime nights, and their receipts from such performances doubled those from regular drama. ${ }^{2}$ Davies declares 3 'that of

1 pp. 367-368.

${ }^{2}$ Genest, III, 158.

Memoirs of the Life of David Garrick, I, 93. 
all the pantomimes which Rich brought on the stage, from the Harlequin Sorcerer, in the year I7I7, to the last which was exhibited a year before his death [176r] ... there was scarce one which failed to please the public, who testified their approbation of them forty or fifty nights successively.' Henceforth, pantomime was firmly established on the English stage.

Not content with his popular triumphs in pantomime, Rich introduced at Lincoln's Inn Fields another powerful rival to regular drama. In The Beggar's Opera (I 728), JoHN GAY (I685-I 732) achieved one of the most conspicuous stage triumphs in English dramatic history. 'The vast Success of that new Species of Dramatick Poetry' was, to Colley Cibber,' further proof of 'the vulgar taste.' 'Cato,' he wrote, 'succeeded, but reach'd not, by full forty Days, the Progress and Applauses of the Beggars Opera.' In another passage, ${ }^{2}$ he declared that 'if the Judgment of the Crowd were infallible: I am afraid we shall be reduc'd to allow that the Beggars Opera was the best-written Play ... . that ever our English Theatre had to boast of.' Yet even Cibber admits that 'that Critick, indeed, must be rigid to a Folly that would deny ... due Praise' to such extraordinary success. The opera that 'made Gay rich and Rich gay' had over sixty performances during the season. ${ }^{3}$ It was

1 A pology, I, 243, 245.

2 Ibid., I, 318.

'The note in The Dunciad (iii, 330), that it was 'acted in London sixty-three days, uninterrupted,' helps to explain frequent misstatements as to the continuous run of the piece. See Genest, III, 222, 227-228. 
the talk of the town; its scenes and verses were represented on fans; its songs were sung everywhere; Lavinia Fenton, who bewitched the town in the part of Polly Peachum, ended by running away with the Duke of Bolton. 'We are as full of it,' wrote Swift ${ }^{1}$ from Dublin, 'pro modulo nostro as London can be; continually acting, and Houses crammed, and the Lord Lieutenant several times there laughing his Heart out.'

Gay's great triumph came after some theatrical experience. Dissatisfied with the trade of mercer to which he had been apprentice, he finally determined to follow his literary tastes. His tragi-comi-pastoral farce, What-d'ye-call-it ( I7 I5) ridiculed popular tragedies, especially Venice Preserved, in the general fashion of The Rehearsal. Pope and Arbuthnot assisted him in the mediocre farce, Three Hours after Marriage ( $\mathrm{I} 7 \mathrm{I} 7)$. The publication of two volumes of poems, in I 720, was an index of much higher gifts.

The germ of the idea of The Beggar's Opera has usually been held to be a passage in Swift's letter ${ }^{2}$ to Pope, 30 August I7I6: 'I believe . . . the Pastoral Ridicule is not exhausted; and that a Porter, Footman, or Chair-man's pastoral might do well. Or what think you of a Newgate Pastoral?' Later, when the suggestion came to Gay, he utilized the Newgate setting but preferred operatic drama to pastoral. According to Pope, Swift at first 'did not much like the project. As he [Gay] carried it on, he showed what he wrote to both of us; and we now and then

1 Dean Swift's Literary Correspondence, I74I, p. 65.

2 Ibid., pp. 9-Io. 
gave a correction, or a word or two of advice, but it . was wholly of his own writing. When it was done, neither of us thought it would succeed. We showed it to Congreve, who, after reading it over, said, "It would either take greatly, or be damned confoundedly.", 1

It was by no means wholly the novelty of a Newgate opera that made the success of The Beggar's Opera. Gay skilfully satirized courtiers and politicians, in particular, Sir Robert Walpole. ' Gay,' wrote William Cooke, 2 'by frequently comparing highwaymen to courtiers, and mixing other political allusions, drew the attention of the public to the character of Sir Robert Walpole, then Prime Minister, who, like most other Prime Ministers, had a strong party against him, who constantly took care to make or find a comparison between the two characters ... The first song was thought to point to him - The name of Bob Booty, whenever mentioned, again raised the laugh against him: and the quarrelling scene between Peachum and Lockit, was so well understood at that time to allude to a recent quarrel between the two Ministers, Lord Townshend and Sir Robert, that the House was in convulsions of applause.' Swift wrote, 'We hear a Million of Stories about the Opera, of the Applause at the Song, That was levelled at me, when two great Ministers were in a Box together, and all the World staring at them.' 3 In other quarters, Gay's burlesque was seriously taken to heart.

1 Spence, Anecdotes, Malone edition, 1820, p. 136.

2 Memoirs of Charles Macklin, 1804, pp. 53-55.

'Dean Swift's Literary Correspondence, 174I, p. 66. 
It was reprehended as 'the most venemous allegorical libel against the Government that hath appeared for many years. . . . The satirical strokes upon Ministers, Courtiers, and great Men, in general, abound in every Part of this most insolent Performance.' 1 In popularizing political satire on the English stage Gay prepared the way for Fielding.

The satire of The Beggar's Opera extended not merely to contemporary politics and society but to Italian opera and sentimental drama. In the Introduction, the Beggar, who gives his name to the opera, in presenting his piece to the Player, says: 'I have introduc'd the Similes that are in all your celebrated Operas: The Swallow, the Moth, the Bee, the Ship, the Flower, \&c. Besides, I have a Prison Scene which the Ladies always reckon charmingly pathetick.' Perhaps Gay had in mind the sentimental scene in Newgate prison which opens the last act of Steele's Lying Lover. The double ending to Gay's work is a palpable hit at the conventional happy ending of sentimental drama and opera. Captain Macheath, confronted with an embarrassment of wives, gives himself up in despair to the officers. Hereupon the Player tells the Beggar that this will never do, for 'this is a down-right deep Tragedy. The Catastrophe is manifestly wrong, for an Opera must end happily.' The Beggar admits that the objection 'is very just; and is easily remov'd. For you must allow, that in this kind of Drama, 'tis no matter how absurdly things are brought about. - So - you Rabble there - run

${ }^{1}$ Watson Nicholson, The Struggle for a Free Stage in London, pp. 49-50. 
and cry a Reprieve - let the Prisoner be brought back to his Wives in Triumph.' Then adds the Player: 'All this we must do, to comply with the Taste of the Town.' But the Beggar rejoins, 'Had the Play remain'd, as I at first intended, it would have carried a most excellent Moral. 'Twould have shown that the lower Sort of People have their Vices in a degree as well as the Rich: And that they are punish'd for them.' No such excuse, however, could shield Gay from the serious attack of some solemn moralists. Sir John Fielding assured Hugh Kelly 'that ever since the first representation of this piece, there had been, on every successful run, a proportionate number of highwaymen brought to the office,' ${ }^{1}$ and showed him the books by way of proof. To the same effect runs the testimony of Oulton ${ }^{2}$ to its 'immoral tendency: as it was never played without encreasing the number of thieves about this metropolis.'

The vein of social satire successfully exploited in The Beggar's Opera was deepened in its sequel, Polly. Its stage production was prohibited by the Lord Chamberlain, but the printed version attracted wide attention. Gay's Beggar had found it 'difficult to determine whether (in the fashionable Vices) the fine Gentlemen imitate the Gentlemen of the Road, or the Gentlemen of the Road the fine Gentlemen.' In Polly, Captain Macheath and his pirates move amid the corruptions of West Indian society, where the 'poor Indian' is exalted into the 'noble savage.' The revolt against the taint of European civilization some-

1 Cooke, Memoirs of Charles Macklin, p. 64.

${ }^{2}$ Bistory of the Theatres of London, 1796, I, 25. 
what suggests the passing mood of some stanzas in Locksley Hall, but with Gay the mood never settles down to Tennyson's conclusion. If it were possible to accept as a serious social creed Gay's satire of society, it might be held to exhibit some foreshadowings of Rousseau's doctrines. But the sava indignatio which had just fired Swift's Gulliver's Travels (I 726) had only a mock echo in Gay. If Gay be concluded to have brought an indictment against the corruptions of civilized society, he was content to have the case laughed out of court.

The Beggar's Opera entitles Gay to a permanent place in the history of English drama. Its ridicule of absurdities of sentimental drama and opera continues the vein of his earlier piece, What-d'ye-call-it, and points toward such dramatic burlesques as Fielding's Tom Thumb and Carey's Chrononhotonthologos. Its political satire anticipates Fielding's farces. In introducing 'ballad opera,' it set a popular fashion which Sheridan was ready to follow in The Duenna. 


\section{CHAPTER XII}

VOLTAIRE'S INFLUENCE AND BOURGEOIS TRAGEDY

THE course of regular English drama during the early Georgian period did not run smooth. Against such powerful rivals as pantomime and ballad opera, comedy and tragedy struggled somewhat unsteadily. Colley Cibber's Non-Juror (I 7 I 7), Mrs. Centlivre's $A$ Bold Stroke for a Wife (I 7 I8), Steele's Conscious Lovers (1722), and Cibber's Provoked Husband ( 1728 ), a completed version of Vanbrugh's unfinished Journey to London, may serve to suggest the less serious types of drama. The development of tragedy may be noted in the works of some dramatists not hitherto discussed.

EDWARD Young ( $1683^{-1765)}$, whose poetic power culminated, much later, in Night Thoughts, produced in Busiris ( 1719 ), a successful blank-verse tragedy, and in The Revenge, a tragedy which held the stage for a century. A third tragedy, The Brothers, whose stage production had been abandoned on account of the author's religious scruples when he took orders, had a belated production, in 1753 , for the benefit of the Society for the Propagation of the Gospel. In the picturesque accounts ${ }^{1}$ of the disputes between author and actors over the performance, Young

${ }^{1}$ Dr. Doran, 'Their Majesties Servants,' Annals of the English Stage, Lowe edition, II, 16r-163. 
is said to have protested against an objection to what he regarded as the most forcible line in the drama 'I will speak to you in thunder.' At all events, the line might well have been his dramatic motto. The violent action and swelling phrases of Busiris needed little heightening when Fielding set himself to travesty them in his burlesque tragedy, Tom Thumb. Young has often been said to follow French models, but the violence and bloodshed of his dramas reflect the freedom of the English stage rather than the restraint of classical tragedy. The Revenge, in its endeavour to portray 'the tumults of a Godlike mind,' suggests the heroic tragedy of the Restoration, while the conception of Zanga, the Moor, is doubtless drawn in part from Iago. The coarse epilogues to Young's plays recall, likewise, a practice of the earlier English stage which had survived Collier's attacks upon the immorality of the theatre. There is, then, marked kinship between Young's tragedies and earlier English drama. Judged independently as a dramatist, Young has, in general, violence, rather than vigour, of action, and heat, without warmth, of dramatic utterance.

JoHN Hughes (I677-I720), who had acquired literary recognition by papers in The Tatler and The Spectator, and had produced an opera, Calypso and Telemachus ( $17 \mathrm{I} 2)$, won on the very night of his death genuine dramatic success with The Siege of Damascus ( 1720 ). Both Swift and Pope regarded him as a mediocre writer in prose and verse alike, but a certain dignity of style and setting may partly justify Duncombe's commendatory lines on The Siege of Damascus: 
No modern phrases in these scenes appear, Antiquity's more noble dress they wear.

While Young inclined largely toward English dramatic models, JAMES THOMson (I 700-I 748) lent the influence of his poetic reputation won in The Seasons to the cause of classical tragedy. In Sophonisba (1730), classical simplicity of plot is deadened by ponderous phrase. Massinissa's invocation, 'Oh, Sophonisba, Sophonisba, oh,' is remembered because of its waggish perversion to 'Oh, Jemmy Thomson, Jemmy Thomson, oh,' and by Fielding's parody in Tom Thumb, 'Oh ! Huncamunca, Huncamunca, oh !' Yet Mrs. Oldfield, as heroine, succeeded for a time in commanding applause. More noteworthy is his collaboration with David Mallet in The Masque of Alfred ( 1 740), performed at a fête given by the Prince of Wales, for to it Thomson contributed the famous ode, 'Rule Britannia.' In Agamemnon (1738), Edward and Eleonora, rejected by the censor, and Tancred and Sigismunda (I745), Thomson relentlessly pursued the path of tragedy. A version of Coriolanus ( 1749 ) heroically struggles to compress the action in conformity with the dramatic unities, and emasculates its vigour. Thomson aimed to couch political and moral sentiments in chaste diction, but if at times 'High Rant is tumbled from his Gallery Throne,' ${ }^{1}$ it only makes way for frigid mediocrity. He thought to reject 'the glittering false Sublime,' but the effort to banish glitter did not banish falsity from his tragedy. The soulless trag.

1 Prologue to Tancred and Sigismunda. 
edies of Thomson and his like were appropriately exposed to the heartless ridicule of burlesque.

The French influence upon English drama has constantly been found exerted in two ways - in classical dramatic theory and in the practice of such dramatists as Corneille and Racine. In both theory and practice French influence derived a new and powerful support from Voltaire. ${ }^{1}$ In 1726 , he began a residence of almost three years in England which placed him in touch, rather than brought him into sympathy, with English drama. Cato he considered a masterpiece of classical tragedy; yet, at least in one passage, he was forced to conclude that 'creative genius' such as Shakespeare's 'moves forward without guide, without art, without rule. It loses its way in its progress; but it leaves far behind it everything which can boast only of reason and correctness.' ${ }^{2}$ But so catholic an utterance as this would convey a wrong impression of Voltaire's habitual point of view. Taste, that touchstone of classical criticism, Voltaire deemed lacking in Shakespeare. Strangely silent as to Shakespeare's comedies, Voltaire readily found monstrosities in his tragedies. 'Shakespear,' he admitted, 'boasted a strong, fruitful Genius: He was natural and sublime, but had not so much as a single Spark of good Taste, or knew one Rule of the Drama.' 3 This, indeed, was the frequent judgment of those Restoration wits who had often to acknowledge Shakespeare's

${ }^{1}$ See for the fullest and most scholarly discussion of Voltaire's influence in England, T. R. Lounsbury, Shakespeare and Voltaire.

2 Quoted by Lounsbury, Shakespeare and Voltaire, p. 52.

'Letters concerning the English Nation (translated), 1733, p. 166. 
dramatic instinct at the very moment that they sought to improve his text. It was, in a word, the concession of classicism to the genius of romantic drama.

When Voltaire set himself the difficult task of translating dramatic theory into practice, his classical taste showed the effect of English contagion. Not merely did he borrow in his own plays from Julius Casar, Othello, Hamlet, Macbeth, and Lear more freely than he was disposed to acknowledge, but he relaxed the rigorous precepts of classical drama in partial deference to English freedom of action. 'France is not the only country where tragedies are written;' he wrote in a letter of 1735 , 'and our taste, or rather our practice, of putting upon the stage nothing but love-dialogues does not please other nations. Our theatre is ordinarily devoid of action and of great interests.' 1 Fifteen years later, in a letter full of strictures on the barbarities of English tragedy, he admitted, 'Tis true we have too much of words, if you have too much of action, and perhaps the perfection of the Art should consist in a due mixture of the french taste and english energy.' 2 The French and English critical war, waged so long and so vigorously, resulted in concessions even by the leaders on both sides.

To the influence of Voltaire's critical authority and to the indirect influence in England of the French production of his plays must now be added the direct influence of versions of Voltaire on the English

1 Quoted by Lounsbury, Shakespeare and Voltaire, p. 71.

Quoted Ibid., p. 138. 
stage. William Duncombe's adaptation of Brutus (I734) proved a lukewarm tragedy, whose dramatic fire could not be stirred by the English innovation of permitting the death of the heroine on the stage. Duncombe's version brought upon Voltaire the charge of plagiarism from Lee's Restoration tragedy, Brutus. ${ }^{1}$ More friendly in tone, but hardly less definite in assertion of Voltaire's debt to English tragedy, was Colley Cibber's Prologue to Hill's Zara (1736; privately presented, I735), a version of Voltaire's Zaïre:

From English Plays, Zara's French Author fir'd, Confess'd his Muse, beyond herself, inspir'd;

From rack'd Othello's Rage, he rais'd his Style, And snatch'd the Brand, that lights his Tragick Pile.

AARon Hill (I685-I 750), whose literary activity had already manifested itself in the libretto to Handel's opera, Rinaldo (I 7II), and in several tragedies, ${ }^{2}$ was encouraged by his success in Zara, to produce in the same year another adaptation of Voltaire, Alzira. Hill's third adaptation from Voltaire, Merope (I 749), failed, like its predecessor, to equal the success of Zara. One other adaptation of Voltaire on the English stage prior to I750 may be mentioned - James Miller's version of Mahomet (I 744). ${ }^{3}$ Its Prologue contains further proof that Voltaire's debt to Shakespeare did not escape English eyes :

${ }^{1}$ Lounsbury, Shakespeare and Voltaire, pp. 75-76.

${ }^{2}$ The Fatal Vision, or The Fall of Siam (1716), The Fatal Extravagance, whose title fits more than one of Hill's works with fatal felicity, King Henry the Fifth, and Athelwold (I73r), a revision of his Elfrid, or The Fair Inconstant.

'A note to the 'fourth edition, with new Improvements' (I 766), of Mahomet the Imposter, says : 'the first four Acts composed by the Rev. Mr. Miller.' 
Britons, these Numbers to yourselves you owe; Voltaire hath Strength to shoot in Shakespeare's Bow.

With English Freedom, English Wit he knew, And from the inexhausted Stream profusely drew.

To trace further Voltaire's influence on English drama would be to carry the present chapter beyond its proper limits. Yet something may be said by way of present summary. The respect accorded to Voltaire's critical authority and the frequency of the English versions of his plays gave him marked influence upon English drama. Yet this influence has sometimes been exaggerated. Many of his plays, in their English version, met with but moderate favour. Zara had a continuous run of fourteen nights, but its success was exceptional. Almost from the outset it was recognized that Voltaire had borrowed freely from Shakespeare, and hence his plays could hardly be expected to conquer ultimately the native genius to whom he was much indebted. Dramas of Shakespeare had far more frequent performance than had the English adaptations of Voltaire's plays, and, as the century advanced, the tide of English criticism set strongly in Shakespeare's favour. Critical editions of his works increased his influence with readers, and Garrick's masterly performances notably deepened Shakespeare's popularity on the stage.

While English tragedy pursued its rather uneventful course during the second quarter of the eighteenth century, one radical departure from the usual types merits attention wholly out of proportion with its 
intrinsic literary value. This was the introduction of prose bourgeois tragedy in Lillo's George Barnwell (I73r). Domestic tragedy itself was, in a sense, no novelty. Apart from somewhat sporadic appearances in such Elizabethan dramas as Arden of Feversham, $A$ Yorkshire Tragedy, and Heywood's A Woman Killed with Kindness, definite examples of it had been furnished by Otway, Southerne, and Rowe. Furthermore, as has already been shown, so-called 'sentimental comedy' was in reality often semi-tragic in character. Though the trials and sorrows of ordinary life did not, therefore, supply a wholly new dramatic motif, they found novel application in the form of tragedy now inaugurated.

It is not surprising that GEORGE LILLO (I693-I 739), when he turned from the trade of jeweller to which his father had brought him up, became the dramatist of bourgeois life. His first piece Silvia, or The Country Burial ( 1730 ) is a ballad opera in which virtue and vice blend rather coarsely. In The London Merchant, or The History of George Barnwell (I73I), Lillo produced a tragedy that stands as a landmark in the history of English drama. The domestic tragedies of Otway, Southerne, and Rowe seem rather to have depressed the aristocratic tone of tragedy than to have exalted its democratic character. Otway's Orphan is more noticeable for the absence of distinctions of rank than for the presence of bourgeois elements. In Jane Shore, Rowe pictures the downfall of a woman of lower class, but the agent of her ruin is an aristocrat. Lillo deliberately set his piece in the surroundings of everyday citizen life. George Barnwell 
is the exaltation of trade. The virtue of the merchant's calling is second only to that of morality. Commercial cleanliness is next to godliness. At the opening of the third act, Thorowgood and Trueman, whose names are significant, show how trade has 'promoted humanity' and how it is 'by mutual benefits diffusing mutual love from pole to pole.' The sacred object of the merchant's calling is thus defined: 'It is the industrious merchant's business to collect the various blessings of each soil and climate, and, with the product of the whole, to enrich his native country.' Charles Lamb ${ }^{1}$ evinced distaste for Lillo's work, but Fielding, in Joseph Andrews, has an ironical fling at those who dislike Lillo because his expression is bourgeois - 'those low, dirty, last dying speeches, which a fellow in the city of Wapping, your Dillo or Lillo, what was his name, called tragedies.' 2

George Barnwell is the story of the ruin of an apprentice by a courtesan. Millwood leads Barnwell steadily downward to theft, murder, and the gallows. The piece suggests Hogarth's plates - Trueman is the industrious, and Barnwell the idle, apprentice. Lillo based his play on an old ballad which presented Barnwell in a less sympathetic light. In the ballad, Barnwell offers of his own accord to rob his father and rich sister to meet Millwood's importunities, and him-

${ }^{1}$ On the Tragedies of Shakespeare. See discussion by A. W. Ward, edition (Belles-Lettres Series) of Lillo's London Merchant and Fatal Curiosily, Introduction, pp. xxviii-xxix. Ward's suggestive and scholarly study of Lillo is an important contribution to the history of English drama.

2 Book III, Chapter X. 
self proposes his uncle's murder, which the Millwood of the play suggests. Lillo emphasizes Barnwell's repentance; the ballad makes but brief mention of the 'fear and sting of conscience' which prompt his written confession. The play enlarges the rather scant materials of the ballad by the introduction of the lovelorn Maria, of Trueman, and of Millwood's servants, Lucy and Blunt.

The conscious moral aim of sentimental drama, apparent in the comedies of Cibber and Steele, reappears in Lillo's tragedy. He cared more to point a moral than to adorn the tale. As if the moralized justice of the dénouement were insufficient, the dialogue is filled with such aphorisms as Thorowgood's, 'When vice becomes habitual, the very power of leaving it is lost.' The Beggar's Opera had been declared an incentive to vice, but there are contemporary documents to prove that George Barnwell could reclaim a sinner. Lee Lewes quotes a long letter ${ }^{1}$ telling of a youthful embezzler who was so struck by the similarity between his situation and that of Barnwell that he wished death, but was happily reclaimed by his father, became an eminent merchant, and annually presented to the actor Ross ten guineas as 'a tribute of gratitude from one who was highly obliged, and saved from ruin, by seeing Mr. Ross's performance of Barnwell.'

Despite the weight of moralizing, Lillo's play has marked unity and dramatic movement. Everything centres in Barnwell, and the plot unfolds clearly and

${ }^{1}$ Memoirs of Charles Lee Lewes . . . Written by Himself, 1805, IV, 243-248. 
inevitably. So much, indeed, is sympathy enlisted for Barnwell as a man more sinned against than sinning that little compassion is felt for the murdered uncle, who is introduced only as a lamb led to the slaughter. The motive of the action does not always seem adequate, nor is the character portrayal consistent. Barnwell might seemingly have robbed his uncle without murdering him. Barnwell meets Millwood's solicitations with the simplicity of unsullied youth; but his immediate yielding to temptation cannot be forgiven on the score of ignorance, since his very words acknowledge guilt. The veneer of morality is superficial - a sort of bourgeois piety that yields almost without resistance. Yet certainly this is not the impression that Lillo sought to convey. Again, if Barnwell is so thoroughly under the spell of Millwood that he commits murder at her suggestion, it is questionable whether he would have left untouched the money which was his object. Stevenson's Markheim, who remains in the shop of the murdered dealer and gives himself up to the police, is hardly a case in point. Millwood is a more logical study in depraved passion. Lillo shows dramatic restraint in allowing the faithful Maria to survive Barnwell's death. Melodrama would have had her die of a broken heart just before the curtain-fall.

Important as was the influence of George Barnwell upon the subject matter of English tragedy, it was no less important in its effect upon its language. Shakespeare's occasional employment of prose in tragedy does not alter the fact that Elizabethan tragedy is essentially poetic both in conception and in phras- 
ing. Lillo attempted to give to domestic tragedy the vocabulary of everyday life. To the modern reader the effect is often grotesque. Highly stilted passages, unnatural inversions of phrase, rhymed 'scene tags,' often not limited to single couplets and sometimes not confined to the last scenes of each act, show that Lillo's language has by no means thrown off all the shackles of old-school tragedy. Yet it is idle to judge Lillo's prose by the standards of a modern drama that has been affected by Ibsen. Artificial as was his expression, Lillo had at bottom the same idea as Wordsworth in seeking to tell a simple story in the prose language of ordinary life. In justice to Lillo it may be remembered that his dialogue does not seem much more artificial than the language of Richardson's novels. The age was accustomed to overcharged phrasing in drama, as it was to the 'grand manner' in acting. Lillo's conception of natural dialogue, however crude, marks a step forward toward modern realism. It was this doubtless that led Fielding, who was so ready to burlesque the tragedies of Young and Thomson and to turn away from the conventional moralizing of Richardson in the novel, to confess appreciation of Lillo. Even Pope, who attended the first performance, though he deemed the dialogue too stilted, found that Lillo had only occasionally been led 'into a poetical luxuriancy, affecting to be too elevated for the simplicity of the subject.' 1 Yet if much is to be forgiven to Lillo, there is no doubt that at times he sinned greatly.

1 The Lives of the Poets of Great-Britain and Ireland. By Mr. [Theophilus] Cibber and other Hands, 1753, V, 339. 
The uncle's soliloquies (III, 6 and 7) go far to justify his murder. They bear the mark of the conventional rhetoric of tragedy, with little gain in their substitution of unpoetic prose for prosaic verse. If the old shackles of verse tragedy have been broken, the marks of the fetters remain visible.

The importance of George Barnwell is not an invention of recent dramatic criticism. Though the first performance of the play did not occur until late in June, it achieved some twenty performances during the summer season, and became a stock play at Drury Lane. It was often acted at holiday seasons, was revived by Charles Kemble, in 1796, and its story was retold in the form of a novel, by T. S. Surr (r798), which had various editions. France, Holland, and Germany felt Lillo's influence. Diderot paid him high tribute and in his own plays introduced on the French stage the 'tragédie domestique et bourgeoise.' Lessing, in turn, through his translation of Diderot's plays, and through his adoption of The London Merchant as the model for his Miss Sara Sampson (1755), brought German drama under the influence of Lillo. Not merely English, but Continental drama, found in Lillo a powerful leader. ${ }^{1}$

In The Christian Hero ( 735 ), Lillo continued to moralize tragedy, but deserted prose and the characters of lowly rank to 'sing a pious hero, and a patriot king.' With a scene set in Albania, with the

2 For further discussion of Lillo's influence on Continental drama, see the present writer's Chapter IV, in Volume X, of the Cambridge History of English Literature, and especially A. W. Ward's edition of Lillo already cited. 
dramatis personce divided between Turks and Christians, Lillo seems to have lapsed into the familiar conventions of tragedy. Much more important is Fatal Curiosity: A True Tragedy of Three Acts (I736). Though Lillo retains blank verse, in his hands a clumsy instrument, he turns again to domestic tragedy. Old Wilmot, impelled by his wife to seek a desperate remedy for their poverty, kills the stranger that is within their gates, only to find that he has murdered his son whom 'fatal curiosity' has led to conceal his identity. With something of the Greek conception, destiny dominates the tragedy. Thus Fatal Curiosity is, as Ward has clearly pointed out,' 'an early experiment in a species to which the Germans, who alone cultivated it to any considerable extent, have given the name of Schicksalstragödie - the tragedy of destiny.' Translation and imitation brought it into influence upon German drama. Upon English drama its influence lay not in the development of the Greek idea of tragedy, but in its domestic character. 'From lower life we draw our scene's distress,' runs a line in the Prologue.

Marina, a three-act drama in which blank verse yields to prose in the needlessly coarse brothel scenes, is based on Pericles, Prince of Tyre. The end shows 'Virtue preserv'd from fell destruction's blast,' but the means hardly justify the end. Three of Lillo's dramatic works were published after his death Britannia and Batavia, a somewhat late survival of the masque, Elmerick, or Justice Triumphant, a tragedy in blank verse, and Arden of Feversham, an adaptation of Elizabethan domestic tragedy.

1 Lillo, Introduction, p. $\mathbf{L}$ 
Lillo's importance in the history of English drama depends primarily on George Barnwell. Artificial as his work may appear to modern taste, he set in motion powerful forces that pointed toward natural tragedy. In attempting 'to show, In artless strains, a tale of private woe,' he consciously divested tragedy of its traditional deference to rank and title and to the ceremonious dignity of verse form. Tragedy still needed emancipation from sentimentalized morality. But if Lillo accepted some conventions of the sentimental school, he was none the less a pioneer in English drama. He animated domestic drama, and in the adoption of prose led the way to prose melodrama and tragedy.

The marked success of George Barnwell must not be mistaken for proof of the dominance of domestic tragedy thereafter on the English stage. Year after year, the London theatres continued to produce a remarkable variety of dramas, from classical tragedy to nondescript farce. Genest's lists show, if not the survival of the fittest, at least a remarkable survival of earlier plays that still proved, for one reason or another, theatrically effective. The season following George Barnwell, for example, saw performances of various plays of Shakespeare, Ben Jonson, Dryden, Etherege, Otway, Southerne, Congreve, Vanbrugh, Farquhar, Addison, Steele, Mrs. Centlivre, and many others. Yet Lillo's continued success had its influence on other playwrights. Charles Johnson, a minor dramatist who usually had his ear to the ground, probably fashioned his moralized tragedy Caelia, or The Perjured Lover (1732), after Lillo's pattern. 
Wronglove is a Lothario who repents after he has been fatally wounded in a duel, while the woman he has wronged dies of a broken heart. Fielding's Epilogue mocks the distressed heroine, but the play itself is a sentimentalized domestic tragedy.

The most conspicuous follower of Lillo was EDWARD MOORE (I7I2-I757). Lillo had been a jeweller's apprentice; Moore, like Gay, was brought up as apprentice to a mercer. It is significant that the aristocratic preferences of tragedy were set aside by playwrights whose origin was as humble as their dramatic themes. Like Gay, Moore was something of a fabulist, showing in his Fables for the Female Sex the conscious moral aim which dominates his important play. Of his early dramatic efforts, The Foundling ( $\mathrm{I} 748$ ), a comedy in which has been detected some resemblance to Steele's Conscious Lovers, gave to Macklin, in the part of the foppish Faddle, an opportunity to mimic an 'agreeable rattle' of the day named Russell. In Gil Blas (I 75I), comedy is darkened with an underplot involving a scheme of assassination, but the author's strong tragic and moral tendencies found fullest expression in The Gamester (I753).

Moore dramatizes a new commandment, 'Thou shalt not gamble.' Addison had already attacked gambling in The Spectator, and Pope had laughed at ombre playing in The Rape of the Lock. Draper, in an unimportant comedy, The Spendthrift (I73I), had introduced a young prodigal ruined by gaming, but had finally reconciled him to his father and mated him to his faithful Jenny. Moore, however, 
strikes no glancing blow at gambling. All his energy centres in one relentless attack which gives unity to his tragedy. Without halt The Gamester advances to its fatal conclusion. At times tragedy stoops to melodrama. Surprise, instead of expectation, is the motive when Lewson appears after the supposed murder. Again, in the opening scene of the last act, Bates recounts the murder to Stukely with no hint that he is inventing the whole story. But if the appeal is made sometimes to theatrical effect rather than to the fundamental motives of tragic action, Moore has escaped some melodramatic pitfalls. Remembering, perhaps, Lillo's restraint in not disposing of Maria in the culmination of his tragedy, he does not allow Mrs. Beverley to expire on her husband's corpse. Less happy, doubtless, is the suppression of actual gambling scenes on the stage. In failing to show his character directly under the spell of the gambling passion, Moore seems to have sacrificed a situation that would have strengthened not merely the drama itself but its acting possibilities. The career of the gambler is shown by effect rather than by cause. The actual gambler's life is seen only in the background. The characters show more dramatic power than Lillo's. Jarvis, the faithful servant, with his offers of money, recalls Orlando's Adam : 'I have a little Money, Madam; it might have been more, but I have lov'd the Poor. All that I have is yours' $(I, I)$. Moore is not without faults in dramatic construction, but there is a certain impressiveness in his main structural outline, and a certain resolute energy in the execution of his design. 
Moore's prose is an improvement over Lillo's, yet is by no means colloquial. There is none of the ease and naturalness of the best dialogue of comic dramatists. Tragedy inclines naturally toward a more elevated style than comedy, but Moore has not mastered the lesson of simplicity. The result is something between Lillo's inverted and quasi-poetic prose and the language of ordinary life.

Moore's name is closely linked with that of David Garrick. His plays were produced at Drury Lane, with Garrick in the leading rôles. Garrick was the Beverley of The Gamester, wrote its Prologue, and, according to the testimony of Davies, ${ }^{1}$ supplied part of the dialogue of the play, especially in the scene between Lewson and Stukely in the fourth act. It is significant in the history of the English stage that the mid-eighteenth century found its dominant influence not in the playwright but in the actor.

1 Memoirs of the Life of David Garrick, 'New Edition,' 1780, I, 166-167. 


\section{CHAPTER XIII}

\section{FIELDING AND THE LICENSING ACT}

THE prestige of conventional English tragedy, somewhat disturbed by Lillo's bold innovations, was further shaken by the destructive force of burlesque. The Rehearsal had turned the laugh against heroic tragedy; Fielding and his fellows ridiculed the absurdities of contemporary eighteenth-century tragedy. John Gay had already pointed the way with his What-d'ye-call-it (I 7 I5), burlesquing especially Otway's Venice Preserved, and had in The Beggar's Opera satirized impartially Italian opera, sentimental drama, and contemporary politics. Yet neither Gay's nor Fielding's influence on English drama was confined to the negative force of burlesque. The Beggar's Opera presented in ballad opera a positive dramatic type. Fielding did not confine himself to ridicule of pompous tragedy, but in many pieces helped to establish the popularity of short dramatic satire. With him farce dared to hold its own with five-act formal drama.

The long dramatic record of Henry Fielding ( $1707^{-1754)}$ began, some two months before he came of age, with the production at Drury Lane of Love in Several Masques (1728). This comedy of the Congreve type, if its characters somewhat betoken the 'raw and unexperienced pen' which its Preface 
modestly admits, has considerable sprightliness of dialogue. Cibber's Provoked Husband had just achieved a run of twenty-eight consecutive nights, and The Beggar's Opera was in the opening weeks of its phenomenal success, yet Fielding obtained a fair hearing. Two years later he launched forth on the flood of dramatic activity. Though some of his early pieces like The Temple Beau (I730) and Rape upon Rape, ${ }^{1}$ or The Justice Caught in his own Trap (I 730) are five-act comedies, Fielding seems for the most part to have followed the advice which he puts into Witmore's mouth in his Author's Farce (I730): 'When the theatres are puppets-shows, and the comedians ballad-singers; when fools lead the town, would a man think to thrive by his wit? If thou must write, write nonsense, write operas, write Hurlothrumbos.' ${ }^{2}$ With a reminiscence of The $R e-$ hearsal, The Author's Farce includes the rehearsal of a puppet-show by an impecunious author, Luckless, who at times suggests Fielding himself. The scene at the Court of Nonsense, introducing such characters as Signior Opera, Sir Farcical Comic, Don Tragedio, and Monsieur Pantomime, obviously satirizes popular theatrical taste. But Fielding did not confine his satire to generalities. Hits at Johnson, the author of Hurlothrumbo, at 'Orator Henley,' and possibly at

${ }^{1}$ Another edition (also I730) gives the main title as The CoffeeHouse Politician, but retains Rape upon Rape as a running-title in the text.

${ }^{2}$ Quotations in this chapter are from W. E. Henley's edition of The Complete Works of Fielding, Vols. I-V. The dates on the facsimile title-pages there reproduced naturally do not always coincide with those of the first stage productions. 
Wilks and Cibber open up the vein of personal satire which he later exploited to the full.

Most entertaining of Fielding's early dramatic work is Tom Thumb, first produced in two acts, in I730, and then expanded to three acts as The Tragedy of Tragedies, or The Life and Death of Tom Thumb the Great...With the Annotations of H.Scriblerus Secundus. This admirable burlesque hits such vulnerable parts of regular tragedy as its conventional opening passages, its heroic themes of love and valour, its pompous phrases and artificial rhymed similes. The tragedy Ghost passes from the sublime to the ridiculous in the apparition of Tom Thumb's dead father, the classical sonority of Thomson's 'Oh, Sophonisba, Sophonisba, oh' is parodied in 'Oh! Huncamunca, Huncamunca, oh!' and the solution by massacre is outdone by half-a-dozen consecutive murders in as many lines, followed by the suicide of the King. Not merely contemporary tragedy but dramatic criticism is burlesqued. A long prefactory essay that pretends to seek authority in Aristotle and Horace, and elaborate paraphernalia of mock critical and explanatory notes, embellish the satire. To the line, 'The mighty Thomas Thumb victorious comes,' this note is appended: 'Dr. B[entle]y reads: The mighty Tall-mast Thumb. Mr. D[enni]s : The mighty Thumbing Thumb. Mr. T[heobal]d reads: Thundering. I think Thomas more agreeable to the great simplicity so apparent in our Author.' It is a mocking echo of the critical controversies over Shakespeare that had begun to multiply since the first critical edition by Rowe in I 709. In the notes, 
likewise, Fielding's hits are specifically aimed not merely at recent tragedies like Cato, Young's Busiris, and Fenton's popular Mariamne (I723), but at the theories of Corneille and the practice of Dryden, Banks, and Lee. Tom Thumb had been anticipated by The Rehearsal and was to be surpassed by The Critic, but it holds its place as one of the few permanently noteworthy burlesques in English drama.

The Covent-Garden Tragedy (1732) continues in part the burlesque method of Tom Thumb, but the manner is coarsened. The mock preface to Tom Thumb is here replaced by 'Prolegomena,' purporting to be a collection of critiques upon the tragedy, perhaps the most significant suggestion being that the characters of Lovegirlo and Kissinda 'are poor imitations of the characters of Pyrrhus and Andromache in The Distrest Mother, as Bilkum and Stormandra are of Orestes and Hermione.' In thus attempting to ridicule Ambrose Philips by degrading tragedy to the stews of Covent Garden, the keen point of Fielding's satire becomes blunt with coarse use.

The real spirit of Tom Thumb was more genuinely revived by HENRY CAREy (d. I743) in Chrononhotonthologos: Being the Most Tragical Tragedy, that ever was Tragediz'd by any Company of Tragedians (I734). Carey was the author of several operas and of the popular ballad Sally in Our Alley. The gift of phrase, which nicknamed Ambrose Philips 'Namby-pamby,' is apparent in Carey's burlesque from the opening speech of Rigdum-Funnidos :

Aldiborontiphoscophornio !

Where left you Chrononhotonthologos? 
to the death of the 'Faithful Bombardinion.' The 'tragedy groan' with which the survivors conclude the piece might properly have been invoked at such earlier phrases as :

His cogitative Faculties immers'd

In Cogibundity of Cogitation.

Carey's burlesque opera, The Dragon of Wantley (1737), hits at the absurdities of formal opera. While Fielding and Carey thus out-Heroded Herod they, like Lillo, in reality promoted sanity in English drama. Tom Thumb is the ironic expression of that revolt against conventional English tragedy which Fielding phrased seriously in his Prologue to Lillo's Fatal Curiosity:

No fustian hero rages here to-night;

No armies fall, to fix a tyrant's right.

Fielding was a prolific playwright. In addition to the regular comedies and the burlesques already mentioned, he wrote many short farces. Some of these, like his early Lottery ${ }^{1}$ and An Old Man Taught Wisdom (1735), are reënforced with popular music, light ditty, and topical song. In The Grub-Street Opera (173r), where mischief-making Master Owen courts the maid-servants, and in The Intriguing Chambermaid (r734), Fielding was unconventional enough to give prominence to servants in his dramatis personce, thus anticipating Townley's well-known farce, High Life Below Stairs (I 759). ${ }^{2}$ The frequent

1 Genest, III, 328, gives I January, 1732, as ' seemingly ist time.'

2 In 1732, an opera called The Footman dealt chiefly with servants who, as in Townley's farce, assume the names of their masters and mistresses. See Genest, III, 356. 
interpolations of song and the adoption of the threeact form show Fielding's independence both of the spirit and structure of formal drama. The Letter Writers (I73I), an outspoken farce in which young Jack Commons comes to town 'resolved to take one swing in the charming plains of iniquity' before being received into Holy Orders, The Debauchees (1732), a comedy which coarsely sets forth the exposure of a lewd Jesuit priest, and Don Quixote in England ( 1734 ), a comedy loosely sketched at Leyden, in 1728 , and enlarged with some satirical 'scenes concerning our elections' and some fifteen songs, alike adopt the three-act form. The Modern Husband (r732) boasts, in the Prologue, a reversion 'to nature and to truth' and a moral purpose which it is difficult to detect in five acts that recount how 'A willing cuckold sells his willing wife.' The considerable success of his adaptation from Molière's Le Médecin Malgré Lui, entitled The Mock Doctor ( $\mathrm{r} 73^{2}$ ), led Fielding to a more important production, The Miser (I733), 'taken from Plautus and Molière,' which won the praise of Voltaire and the plaudits of Drury Lane audiences. An ill-fated comedy, The Universal Gallant (I735), and an unpublished piece called Deborah (acted but once, I733), complete the varied dramatic record of Fielding prior to his important dramatic satire, Pasquin.

In contrast with the great Patent Theatres, Drury Lane and Lincoln's Inn Fields, the 'Little Theatre in the Haymarket' had followed a desultory career. Since its opening, in $\mathbf{1} 720$, motley had been its usual wear. French comedians, acrobats, rope-dancers, 
and tumblers had taken their turn on the boards. Genest's fitful records of its early performances show productions of burlesque opera, rough comedy, and such medleys as Hurlothrumbo, or the Supernatural (I 729). In this the author, a dancing master named Johnson, himself acted the part of Lord Flame, 'speaking sometimes in one key, and sometimes in another, sometimes dancing, sometimes fiddling, and sometimes walking upon stilts.' ${ }^{1}$ With the production of The Author's Farce and Tom Thumb, in 1730 , the Haymarket secured a succession of pieces by Fielding, and begins to demand more attention. In 1733 , it had the brief éclat of performances by the leading actors who had seceded from Drury Lane. Yet it had acquired but slender dramatic tradition when, in 1736 , Fielding, now its manager, convulsed the town with more than forty performances of Pasquin.

Pasquin is 'a Dramatick Satire on the Times.' In introducing rehearsals of both a mock comedy and a mock tragedy it elaborates the device of The $R e$ hearsal already used in The Author's Farce. Like some of Fielding's other farces, it seems to have supplied Sheridan with hints for The Critic. ${ }^{2}$ Trapwit's comedy boldly satirizes political bribery and corruption, pointing at Sir Robert Walpole and the creed now commonly attributed to him in his supposed generalization that every man has his price. The burlesque tragedy presents "The Life and Death

1 Genest, III, 247.

2 See, for specific parallel passages, the present writer's Major Dramas of Sheridan, Introduction, pp. Ixxxviii-xci. 
of Queen Common Sense,' and, for that matter, her resurrection, for it is her Ghost who finally drives Ignorance off the stage. Upon this, Fustian, the tragic poet, remarks that 'this is almost the only play where she [Common Sense] has got the better lately.' Though Fielding himself was ready enough to cater to the popular taste for entertainments, he puts into the mouth of Fustian (Act V) a hit at pantomime which might have satisfied even Colley Cibber. Tumble-down Dick, or Phaeton in the Suds (1736) ${ }^{1}$ burlesqued a Drury Lane production, The Fall of Phaeton, and in the dedication of the piece to $\mathrm{Mr}$. John Lun [Rich's stage name] hit at Rich's unsuccessful production at Covent Garden of Marforio, a satire on Pasquin. While London was still laughing at Pasquin, Fielding produced Lillo's Fatal Curiosity, and as at first this tragedy met with but moderate success, he added it to his own Historical Register for 1736 in the following season, thus securing for it further hearing.

During the season of 1737 , Fielding developed to the full at the Haymarket his novel method of dramatic satire. The Historical Register for 1736 (acted I737) introduced political satire in allusions to Sir Robert Walpole in the character of Quidam, theatrical satire in hits at Colley and Theophilus Cibber, at the controversy between Mrs. Clive and Mrs. Cibber as to the part of Polly, and at the dilemmas of the 'Green Room,' and social satire, as in the parting

${ }^{1}$ I am indebted to Professor W. L. Cross for copies of contemporary playbills of April, 1736 , which disprove the usual assignment of this play to 1737 . 
fling at the ladies' literary clubs which seem to have espoused the rival causes of Shakespeare and of Beaumont and Fletcher. One of the most vigorous scenes, that of the auction, introduces, as Mr. Hen, the familiar figure of Cock the Auctioneer. Nor did Fielding spare himself, for in Eurydice Hissed, or a Word to the Wise, he dealt with the failure of his own farce Eurydice at Drury Lane.

The reckless freedom of Fielding's satire was carried too far for its own safety. Whatever the immediate provocation, it was largely due to Fielding that the law took cognizance of the lawlessness of dramatic satire. In March, I735, Sir John Barnard had interested himself in the House of Commons in the question of restricting the theatres, and, though his bill was finally abandoned, the theatrical situation came up for discussion. This occurred before Pasquin and the Historical Register had dealt their satirical attacks, especially upon Sir Robert Walpole. The immediate stimulus to the Licensing Act is usually held to have been an abusive piece, called The Golden Rump, which led Giffard, manager of the Goodman's Fields Theatre, to consult Walpole with immediate results. According to some accounts, ${ }^{1}$ even this piece is to be attributed to Fielding. In any event, there is little reason to doubt that Walpole recognized in Fielding his most dangerous foe. 'Religion, Laws, Government, Priests, Judges and Ministers,' declared Cibber' ${ }^{2}$ bitterly, 'were all laid flat, at the

1 Horace Walpole, Memoirs of the Reign of King George the Second, second edition, revised, 1847, I, 13-14, footnote.

Apology, I, 287. 
Feet of this Herculean Satyrist! This Drawcansir in Wit, that spared neither Friend nor Foe!' The Licensing Act of 1737 limited the metropolitan theatres to two, and brought plays, prologues, and epilogues under direct legal authority. It is true that the Lord Chamberlain had already prohibited some dramatic pieces, ${ }^{1}$ notably Gay's Polly, but with the passage of this act and the appointment of a licenser under his jurisdiction, in 1738 , the Lord Chamberlain was formally invested with the censorship of the stage. Popular indignation at the restrictions of the Licensing Act found vent in a riot at the attempted performance at the Haymarket, in October, I 738, of a French company of comedians who sought to fill the place debarred to English actors. According to the account in The Gentleman's Magazine (Oct. 1738), 'when the Bill appeared' for the first performance of these French actors, 'with the Word AUTHORITY placed at Top, the Publick was stung to the Quick, and thought themselves concerned to exert that Liberty they enjoy, and to resent the Affront put upon them by the Chamberlain.' Henceforth the London stage knew the authority of the censor.

If the Licensing Act was designed to check the reckless satire of Fielding, it was successful. The Haymarket productions of 1737 mark the virtual close of Fielding's theatrical activity. Miss Lucy in Town (1742), a short farce with songs, for which he declared he was but partly responsible, a five-act comedy, The Wedding-Day ( $\mathrm{r} 743$ ), in which Garrick

1 The Restauration of King Charles the Second had been 'forbidden to be acted,' in I732. Genest, III, 357-358. 
took a leading part, and the posthumous comedy, The Fathers, or The Good-Natured Man (I778), , whose chief interest perhaps lies in the subtitle and in the Prologue which appeals for indulgence to the author on the score of his great novels, are of little significance, and represent largely early dramatic material. Perhaps it was not without relief that Fielding turned from the theatre. He had written in haste, and his later comment that he 'left off writing for the stage when he ought to have begun' 2 seems to show that he repented at leisure. In Eurydice Hissed, Honestus bids the author whose 'farce without contrivance, without sense' may win accidental popularity

Think how you will be read in after-times, When friends are not, and the impartial judge Shall with the meanest scribbler rank your name.

The author of Tom Thumb and Pasquin can hardly suffer such a fate; yet his worst pieces sink to sheer mediocrity.

Fielding's dramatic work forms a period of literary apprenticeship. It bears to his great novels somewhat the same relationship as do Thackeray's burlesques to his novels. Fielding and Thackeray alike show in their early work vivacity, humour, satire. Yet burlesque is but negative, and their positive genius awaited full expression in the mature character portrayal of their novels. Nevertheless, Fielding is neither a negligible nor a wholly destructive force in English drama. Careless in conception and hasty in execu-

${ }^{1}$ Genest, VI, 77, under 30 November, 1778.

'Quoted by Austin Dobson, Fielding, p. $5^{8 .}$ 
tion as was most of his dramatic work, its influence was significant. While regular comedy was being increasingly sentimentalized and tragedy moralized, he let satirical farce and burlesque trample on the five-act formula and conventional spirit of formal drama. He was essentially the playwright of his own day. Even Lillo, who set his face against aristocratic tragedy, still conceded the historic background in assigning, nominally at least, an Elizabethan setting to The London Merchant, in placing Fatal Curiosity in the reign of James I, and in choosing Arden of Feversham as the theme of 'an historical tragedy.' Fielding turned to the immediate present. Contemporary society, drama, and politics gave him themes ready to hand. Though he paid some heed to regular comedy, especially in early plays that follow Congreve's general model, he was peculiarly at home in satirical farce. He developed Gay's 'local hits' at politicians of the day, and, like his follower Samuel Foote, carried personal allusion and innuendo to daring extremes. Without the range of a great comic dramatist, Fielding heightened farce with the zest of contemporary caricature.

Although the public made hue and cry over the Licensing Act, the real danger to English drama of that day lay deeper than in the restriction of its freedom of speech. In point of fact, Samuel Foote was soon to show that not merely liberty, but license, of phrase could be compassed in defiance of authority. The vital peril to English drama lay in its dead level of mediocrity. Constant buffetings from almost every quarter had enfeebled its vitality. Italian 
opera, pantomime, burlesque, ballad opera, farce, and spectacle had sorely wasted the ranks of regular comedy and tragedy. Against such dangerous rivals 'legitimate drama' could muster but sorry force. Comedy showed frequent traces of Restoration immorality, but hardly a sign of its comic power, while the sentiment which Steele had substituted had declined into flabby sentimentality. Tragedy wavered between respect for classical conventions and the need of larger life. If it followed Continental example, it was apt to catch the chill formality, but not the stately spirit, of classical drama; if it followed English dramatic models, it was more apt to imitate their crudities and exaggerations than their native strength. To the rivals which it encountered on the actual stage must now be added a new and more subtle rival off the boards.

The Queen Anne age, in which the periodical essay had reached the height of popularity, had passed when Robinson Crusoe (I719) and Gulliver's Travels (I 726) fired the fancy of English readers. With the advent of Richardson's Pamela (I 740) the English novel began its great period of literary dominance. Fielding himself, from minor dramatist, became major novelist in Joseph Andrews (1742), beginning, in accordance with his dramatic schooling, with burlesque of Richardson's novel, but rising out of it into the 'human comedy' of Parson Adams. As one looks askance at the playbills of the new dramas of the mid-eighteenth century, it is necessary to recall that, within the four years from 1747 to 1751 , appeared Richardson's Clarissa Harlowe, Smollett's Roderick 
Random and Peregrine Pickle, and Fielding's Tom Jones (I749), and that the first volumes of Sterne's Tristram Shandy were soon to follow (1759-1760). In the decline of drama the novel had found its opportunity. 


\section{CHAPTER XIV}

\section{THE GARRICK ERA}

Despite the formidable foes that threatened English drama in the middle of the eighteenth century, two powerful forces helped to sustain the vitality of the theatre. These were the strong repertory of 'stock plays' which maintained the continuity of dramatic tradition and the genius of actors able to triumph not merely in the successes of the past but even in the mediocre productions of contemporary drama. Unlike other forms of literature, the drama is primarily dependent upon the actual conditions of its presentation. Yet this very circumstance which has often militated against the dramatist proved in this crisis his surest support. It was the age of the player, not of the playwright. The mideighteenth-century dramatic period is the 'Garrick era.'

Though the record of DAvid GARRICK (I I I 7-I779) belongs primarily to theatrical annals, it is vitally connected with the course of English dramatic history. Apart from his own dramatic productions, Garrick in an extraordinary measure increased the popularity of Shakespeare, besides partly redeeming his texts from current perversions. The natural methods of his art affected not merely the old school of acting but the artificiality of the drama itself. 
The son of a recruiting army captain, David Garrick appropriately made his venture as an actor about the age of eleven, in the part of Serjeant Kite, in Farquhar's Recruiting Officer. There was little chance that Garrick, who had come under the tutelage of Samuel Johnson, would long continue in his uncle's trade of wine merchant. In I740, his mythological skit, Lethe, was produced at Drury Lane, and, with various alterations, long held a place in the repertory. Though Garrick acted, in the summer of I74I, with a travelling company at Ipswich, he was refused admission to the companies of Drury Lane and Covent Garden. But on I9 October, I74I, he made his historic triumph at Goodman's Fields. In deference to the Licensing Act, the playbill announced, somewhat guardedly, that there would be performed ' $A$ Concert of Vocal and Instrumental Music,' between whose parts would be presented 'an Historical Play, called the Life and Death of King Richard the Third.' Garrick awoke to find himself famous. London flocked to Goodman's Fields. The plague that fell upon the rival houses was the 'Garrick fever.' Quin, the chief tragedian of the old school, recognized the passing of the old order of acting by declaring that, 'if the young fellow was right, he, and the rest of the players, had been all wrong.' 1

There is no need to detail here the familiar episodes of Garrick's life - the ménage with Peg Woffington and Charles Macklin, the dissensions among the Drury Lane actors and the consequent breach with Macklin, Garrick's appearances at Covent Garden

'Thomas Davies, Memoirs of Garrick, 'New Edition,' 1780, I, 44. 
and at Dublin, and his final installation, with Lacy, as manager of Drury Lane in $\mathrm{r} 747$. It will suffice to indicate some of the ways in which his dominance as actor and manager affected the course of English drama. Highly suggestive is the picture by Sir Joshua Reynolds which shows Garrick torn between the rival Muses of Tragedy and Comedy. From Richard III he turned to the part of Clodio, in Cibber's early comedy, Love makes a Man; from Chamont in Otway's Orphan to Jack Smatter, in Dance's dramatization of Richardson's Pamela; from characters in his own Lethe and in his farce, The Lying Valet, to Lothario in Rowe's Fair Penitent. During his first season he acted also such different rôles as the Ghost in Hamlet, Fondlewife in Congreve's Old Bachelor, and Witwoud in his Way of the World, Aboan in Southerne's Oronooko, Costar Pearmain, and later Captain Brazen, in Farquhar's Recruiting Officer, Bayes in The Rehearsal,1 Lear, Pierre in Otway's Venice Preserved, and Lord Foppington in Cibber's Careless Husband.

Such a record proves more than Garrick's extraordinary versatility and his impartiality as towards tragedy and comedy. It shows the remarkable dependence of the theatre upon the drama of the past. If it be argued that Garrick's record is an exceptional instance and proves little more than an actor's natural prudence in adhering to established successes, it may be answered that Garrick's name

1 Garrick made this one of his most popular comic parts, introducing imitations of various actors of the day in the passages where Bayes instructs the players how to speak their lines. 
would have been sufficient magnet for any novelty. An interesting indication of the public insistence upon the appearance of their favourite is in the Prologue to Fielding's Wedding-Day, where Macklin, humorously apologizing because Garrick does not speak the prologue, prefaces the announcement with the assurance that he 'performs a principal character in the play.' Furthermore, despite inevitable variations in acting repertory from year to year, Genest's Drury Lane lists, perhaps the most representative of the status of regular drama, show from the season of I 734-1 735 onward to Garrick's time remarkable dependence on stock drama. The poverty of dramatic novelties was counterbalanced by the wealth of successful stock plays.

One especial feature of Garrick's revivals of earlier drama merits especial notice - his Shakespearean productions. Shakespeare had, indeed, recovered in part from the sorry treatment to which he had been subjected in Restoration alterations. The early eighteenth century had not hesitated to adapt or remake Shakespeare after its own fashion, as in Dennis's versions of The Merry Wives and Coriolanus ${ }^{1}$ or in Cibber's theatrically successful Richard III, but as the century advanced there was a growing tendency to revert toward the original texts. To this the increase of critical editions of Shakespeare's works inevitably contributed. Before the middle of the century, Rowe's pioneer work had been fol-

1 Entitled respectively, The Comical Gallant, or The Amours of Sir John Falstaffe (1702), and The Invader of his Country, or The Fatal Resentment (1720). 
lowed by the critical work of Pope, Theobald, Hanmer, and Warburton. Even before the advent of Garrick, there were not wanting signs of increasing response on the part of theatregoers to productions of Shakespeare. In February, I738, Rich, who had in previous seasons given over Covent Garden largely to such varied attractions as pantomime, French dancing, opera, and the long series of performances of Handel's oratorios and operas, began a noteworthy succession of Shakespearean revivals. Plays like Richard II, Henry IV, Part II, Henry V, and Henry $V I$, Part $I$, set down loosely in the playbills as not acted for forty or fifty years, and probably in some cases not really acted for a much longer period, were produced within six weeks. The inclusion in the series of King John, 'as written by Shakespeare,' recalls a suggestive bit of theatrical history. The year previous Cibber had put into rehearsal at Drury Lane his alteration of King John, but 'so much had been said by the critics, who wrote against Cibber, in commendation of the original play,' ${ }^{1}$ that not merely did Cibber withdraw his piece but Rich, always alert to cater to the taste of the moment, successfully revived the original play at Covent Garden. Pope, in The Dunciad, with the line 'King John in silence modestly expires,' and Fielding, in The Historical Register, in the scene where Ground-Ivy ex-

${ }^{1}$ Genest, III, 504. The sequel to this incident is curious. On 15 February, 1745, Cibber's version, entitled Papal Tyranny in the Reign of King John, was produced at Covent Garden, and was immediately answered by the Drury Lane revival of Shakespeare's play, both versions attaining a number of performances. Genest, IV, 146, 158-162. 
plains at length how to alter King John, effectively ridiculed Cibber's ability to 'alter Shakespeare for the worse.' 'It was a maxim of mine,' says GroundIvy, 'that no play, though ever so good, would do without alteration.'

From the Restoration period onward, Shakespeare's leading tragedies had constantly triumphed over the mutilations of revisers and the inanities of critics, but the comedies, with the exception of The Merry Wives of Windsor, had been habitually slighted. With the eighteenth century, the Shakespearean comedies fared better. In the Drury Lane season, I740-174I, that preceded Garrick's advent, there were revivals of As You Like It, Twelfth Night, both parts of Henry $I V$, and, most notably, of The Merchant of Venice. Macklin discarded not merely Lord Lansdowne's current text in favour of Shakespeare's but the traditional admixture of low comedy in the conception of Shylock. Notwithstanding general prophecies of failure, Macklin won a triumph which is familiar from the couplet popularly ascribed to Pope:

This is the Jew

That Shakespeare drew.

Thus, even before the appearance of Garrick, there was evidence of growing thoroughness in the appreciation of Shakespeare's dramatic genius and of increasing fidelity to his text and spirit. The day had long since passed when two of Beaumont and Fletcher's pieces were produced to one of Shakespeare's.

Though the test of time had already established 
Shakespeare's supremacy among the earlier English dramatists, Garrick powerfully confirmed his popularity with theatregoers. As arbiter of Drury Lane, it lay in Garrick's power to set the fashion, and he set it decisively. As manager, he produced more than a score of Shakespeare's dramas, and, as actor, took part in the great majority of these productions. For the most part his influence was highly beneficial, but he did not wholly shake off the bad habits of some of his predecessors. Though he largely restored the original texts of various plays, he was not without the actor's craving for theatrical situation. When he substituted Romeo and Juliet, in 1748, for Otway's popular Caius Marius, he took the hint from Otway's melodramatic device of awakening Lavinia in the tomb before the death of Young Marius. He even ventured to lay violent hands on Hamlet, which had been shielded from adaptation largely by the tradition of Betterton's acting, though according to Davies, ${ }^{1}$ his ' audience did not approve what they barely endured.' Early in 1756 , he produced within a month alterations of three Shakespearean comedies. If to The Taming of the Shrew he applied the pruning-knife, it was, in Puff's phrase, 'the axe' that he set to The Winter's Tale, lopping from it most of the first three acts, though professing in the Prologue to his 'Dramatic Pastoral,' Florizel and Perdita :

'Tis my chief Wish, my Joy, my only Plan, To lose no Drop of that immortal Man!

1 Thomas Davies, Dramatic Miscellanies, 1784 , III, 146. 
Still less defensible was the operatic version of The Tempest, a sorry mixture of Shakespeare and Dryden, for which Garrick was responsible as manager, if not as compiler also. In a Dissertation, too frank for full quotation, Theophilus Cibber unsparingly attacked these very alterations of Garrick, and demanded, 'Were Shakespear's Ghost to rise, wou'd he not frown Indignation, on this pilfering Pedlar in Poetry - who thus shamefully mangles, mutilates, and emasculates his Plays?' 1 Cibber, to be sure, argued rather from Garrick's most flagrant exceptions than from his usual rule, but there is danger of exaggerating the fidelity of the actor's adherence to Shakespeare's original texts. A fairer view would be that, if Garrick sinned at times, he was one to whom much should be forgiven. If he frequently violated the letter, he nobly served the spirit, of his master. The stimulus which he gave to Shakespeare's popularity at Drury Lane directly affected the rival house. In I 750, Barry, Macklin, and Mrs. Cibber at Covent Garden produced Romeo and Juliet in nightly rivalry for almost a fortnight with Garrick, Woodward, and Miss Bellamy at Drury Lane, and in 1756 , the struggle between the Lears of the two great Patent Theatres brought forth such epigrams as :

A King - nay, every inch a King;

Such Barry doth appear:

But Garrick's quite a different thing;

He's every inch King Lear. ${ }^{2}$

${ }_{1}$ Dissertations on Theatrical Subjects, I756, p. 36.

${ }^{2}$ Genest, IV, 469. See also Theophilus Cibber, op. cit., 'Second Dissertation,' pp. 43-47. 
The increasing recognition of Shakespeare naturally had its bearings on the English attitude toward French drama and dramatic standards. The success of Ambrose Philips in The Distrest Mother had stimulated more than a dozen translations of plays by Pierre and Thomas Corneille and by Racine within eighteen years. But from the appearance of William Hatchett's Rival Father (1730), a version of Thomas Corneille's La Mort d'Achille, twenty years elapsed before interest revived in translation from French classical drama. During this interval The Distrest Mother continued to hold the stage, but not even Voltaire's superlatives about Cato could reawaken fully the old enthusiasm for the classical school of Philips and Addison.

The deference at first accorded to Voltaire's critical opinions had likewise perceptibly lessened. The very men who adapted Voltaire's plays to the English stage flatly proclaimed his indebtedness to Shakespeare, and resented both the substance and the tone of his strictures on English drama. In the Advertisement to Merope (I 749), Aaron Hill says of Voltaire: 'So much over-active Sensibility, to his own Country's Claims: With so unfeeling a Stupidity, in judging the Pretensions of his Neighbors, might absolve all Indignation, short of gross Indecency; toward one who has not scrupled . . . to represent the English as incapable of Tragedy; nay, even of Painting, or of Musick.' Even Arthur Murphy, whose Orphan of China (1759)

1 Quoted by Lounsbury, Shakespeare and Voltaire, p. 153. The whole chapter, 'Resentment of the English,' is particularly valuable. 
was the most successful of the later English adaptations of Voltaire's tragedies, tempered his general praise of Voltaire by observing: 'We islanders have remarked of late that $M$. de Voltaire has a particular satisfaction in descanting on the faults of the most wonderful genius that ever existed since Homer.' ${ }^{1}$ The plain speech of Voltaire's translators became in less friendly mouths violent denunciation. In 1747 , Foote vigorously attacked Voltaire as 'that insolent French Panegyrist, who first denies Shakespear almost every Dramatic Excellence, and then, in his next Play, pilfers from him almost every capital Scene,' and pictured him in his dual rôle of critic and dramatist as 'the carping superficial Critic and the low paltry Thief.' 2

Extreme bursts of patriotic ire must not, however, be mistaken for proof of general contempt for Voltaire. Garrick himself acted in Mahomet, Merope, and The Orphan of China, appearing eleven times in the second and nine times in the last of these plays during their first seasons. ${ }^{3}$ Other adaptations of Voltaire's tragedies were essayed, though with less success, in Orestes (I 768), Almida and Zobeide (I77I), and Semiramis ( 776 ). These versions, though varying considerably in point of adherence to their originals, in general show compromise between French restrictions and English freedom. Voltaire himself, under Shakespeare's influence, had relaxed the letter of the classical

${ }^{1}$ Quoted by Lounsbury, Shakespeare and Voltaire, p. 150.

${ }^{2}$ The Roman and English Comedy Consider'd and Compar'd, I747, pp. $21-22$.

Figures based on Genest, IV, 269, 272, 549, 555. 
law, even permitting the introduction of ghosts in Eriphyle and Sémiramis. His adapters did not hesitate to abridge long declamatory speeches, to invigorate the action, and to break over various minor conventions of classical drama. Some of Voltaire's comedies had an English rendering, as in Murphy's No One's Enemy but His Oren (1764), founded on L'Indiscret, and in Colman's successful version of L'Écossaise in The English Merchant ( $\left.\mathrm{I}_{7} 67\right)$. Voltaire thus continued through the third quarter of the eighteenth century to contribute to English drama; but few of his pieces attracted more than temporary interest, and some were actual failures. Merope had occasional revival at Drury Lane and seems to have inspired John Hoole's Cyrus ( 1768 ). The Orphan of China was reproduced, with indifferent success, at Covent Garden in 1777 , and at Dublin in 1810 . Yet, in point of actual stage popularity, even these dramas did not surpass some of the native English tragedies of the day. Occasional tragedies, such as Murphy's Alzuma (I773), show the continued influence of Voltaire; but playwrights were more ready to imitate than the public was to applaud such borrowings. On the critical side, Voltaire's extreme censures of Shakespeare met with increasing disfavour, yet his influence counted strongly in maintaining the belief that Shakespeare's now indisputable supremacy was the triumph of genius over the canons of dramatic art. Great as was the progress of Shakespeare's reputation during the Garrick era, it was not yet fully understood that he was not merely a great dramatist but a great dramatic artist. 
Shakespeare's popularity did not lead to the general adoption of Elizabethan models by the dramatists of the Garrick era. The publication, in I 744, of Dodsley's famous collection of old plays, which with few exceptions antedate the Restoration, is evidence chiefly of awakening literary interest in the history of earlier English drama. An occasional adaptation like Garrick's Gamesters (I 757), altered from Shirley's Gamester, seems somewhat accidental. Otway, Southerne, and Rowe were greater favourites in tragedy than any of the Elizabethans save Shakespeare. Yet such English examples hardly seem to have drawn such deliberate imitation as is discernible in plays that follow the classical model.

In Irene (I 749), DR. SAMueL Johnson (I 709-I 784) produced a chill tragedy which not even the loyal efforts of his former pupil, Garrick, could warm into real vitality. The scene set in Constantinople after its fall has the faint local colour to be found in the old heroic tragedies, and the theme, which turns on the temptation of the Greek maiden Irene by the offer of a throne rejected by the more loyal Aspasia, is equally aloof from ordinary life. The moralizing spirit of sentimental drama finds expression in such precepts as 'Angelic Greatness is Angelic Virtue,' and

Be virtuous Ends pursued by virtuous Means,

Nor think th' Intention sanctifies the Deed. ${ }^{1}$

At the end the didactic note is apparent in the lines which proclaim 'the Justice of all-conscious Heav'n.'

1 These are but two of the maxims inflicted upon Irene by Aspasia (III, 8). See 1749 edition, pp. 42, 44 . 
One is tempted to borrow from Johnson's Prologue spoken by Garrick at the opening of Drury Lane, in 1747, some of the lines in which he brought his excellent review of English drama down toward his own day:

Then crush'd by Rules, and weaken'd as refin'd, For Years the Pow'r of Tragedy declin'd;

From Bard, to Bard, the frigid Caution crept, Till Declamation roar'd, while Passion slept.

Though declamation did not roar with Garrick, passion slept with Irene.

In 1750, William Whitehead (I7I5-I785), later poet laureate, in a version of Horace entitled The Roman Father won a success only second to that of The Distrest Mother among the English versions of French classical tragedy. For half a century The Roman Father remained a stock play, and its success was doubtless the chief stimulus to some eight or ten other translations from the dramas of Pierre and Thomas Corneille and Racine during the last half of the eighteenth century.

Of original dramatic power there are few traces in the tragedies of the Garrick era. Never perhaps in English dramatic history has the poverty of the playwright been so generously aided by the wealth of the actor. The new tragedies which won success in the first decade after the mid-century include, besides Moore's Gamester which has been discussed previously, Jones's Earl of Essex (1753), Crisp's Virginia (1754), Brown's Barbarossa (I754), and Home's Douglas (1756). Of these the first reworks the theme of 
Banks's Unhappy Favourite, which still held the stage and had been produced that very season, and the second and third gave to Garrick the parts in which he most frequently appeared during their respective seasons of $1753^{-1754}$ and $1754^{-1} 755$. Crisp's Virginia, a mediocre handling of a familiar dramatic subject, probably suggested Moncrief's Appius (I 755). The part of Achmet in Barbarossa, which Garrick played no less than sixteen times in its first season, was that in which 'Master Betty,' the 'Young Roscius,' made his extraordinary London début at Covent Garden, in I804.

JoHN HoMe (1722-I808), a Scotch minister who eventually paid for dramatic enterprise in the enforced resignation of his clerical charge, obtained in Douglas ( 1756 , Edinburgh; I 757, London) a success that led some enthusiasts to hail him as the 'Scotch Shakespeare.' His first dramatic ventures promised little. While settled in his East Lothian parish he wrote a tragedy, Agis, which Garrick rejected. In I 755 he travelled to London on horseback with the manuscript of Douglas, only to encounter another rejection from Garrick. But Home was a prophet who found honour in his own country. In December, 1756, Douglas was produced in Edinburgh and became a national triumph. A few months later, Rich produced it at Covent Garden ${ }^{1}$ with Barry and Peg Woffington, and its success led Garrick to accept Agis. Later tragedies, The Siege of Aquileia (1760), The Fatal Discovery (I769), Alonzo (I773), and Alfred

${ }^{1}$ Its initial success in London has at times been exaggerated. Genest, IV, 495, under date of 28 April, 1757, records its ' 9 th and last time' of production that season. 
(1778), met with indifferent reception or failure. Home's fame rested on his one great triumph.

In the barren ground of Scotch drama it is not surprising that Douglas seemed an oasis. The familiar ancedote of the Scotchman who was said to have risen in the pit triumphantly with the words, 'Weel, lads; what think ye of Wully Shakespeare noo,' reflects more patriotism than judgment. Yet Thomas Gray, in a letter, August, 1757 , declared ${ }^{1}$ : 'I am greatly struck with "The Tragedy of Douglas;" though it has infinite faults: The Author seems to me to have retrieved the true Language of the stage, which had been lost for these hundred years, and there is one scene (between Matilda and the old Peasant) so masterly, that it strikes me blind to all the defects in the world.' The philosopher Hume ascribed to his friend Home 'the true theatric genius of Shakespear and Otway, refined from the unhappy barbarism of the one, and licentiousness of the other.'2 If this extraordinary verdict showed that there were more things in heaven and earth than were dreamt of in Hume's philosophy, it was counterbalanced by Doctor Johnson's severe dictum that ' there were not ten good lines in the whole play.' ${ }^{3}$ At all events, its stage success was indisputable. Home received a gold medal from Thomas Sheridan, a pension from the Princess of Wales, and the plaudits of the pit.

1 The Letters of Thomas Gray, edited by D. C. Tovey, 1900-1912, I, 335, footnote 2. Genest, who says Gray's letter was to Walpole, has (IV, 490) many variants in his text.

'The Philosophical Works of David Hume, edited by Green and Grose, 1874-1875, III, 67.

'Boswell's Life of Johnson, Hill edition, I887, V, 360 . 
To-day Douglas is remembered chiefly by Young Norval's speech, long a favourite piece for declamation, 'My name is Norval: on the Grampian hills, My father feeds his flocks' (II, I). The extravagant praises of Home's contemporaries have sometimes reacted nowadays against a fair appraisal of the play. In contrast with the frigid dulness of many classical imitations, Douglas strikes a distinctly romantic note. As the successor of Robert Blair, author of The Grave, in his East Lothian parish, and the friend to whom William Collins inscribed his Ode on the Popular Superstitions of the Highlands, Home had breathed a romantic atmosphere. Douglas is based on the old ballad, 'Child Maurice' - the Scotch 'Gil Morrice' which found a place in Percy's Reliques. The tone of brooding melancholy and the touches of nature, which differentiate its background from the unreal foreign setting of so many conventional tragedies, impart to Douglas a novel tinge of romanticism. It is not difficult to detect flaws in its dramatic construction. Action sometimes gives way to declamation, and the scene between Lady Randolph and her confidante, Anna, handles exposition in a fashion so artless that Sheridan may have taken a hint from it for Tilburina and her confidante in The Critic. Sheridan, also, may have burlesqued some passages, such as Lady Randolph's utterances and Young Norval's familiar lines. ${ }^{1}$ But such parody would at least attest the continued stage popularity of Douglas. The frequent suggestion that Garrick rejected the tragedy because

1 See for specific discussion, the present writer's Major Dramas of Sheridan, Introduction, pp. ciii-cv, and Notes, p. 312. 
he feared that his part might be overshadowed is open to question, but it is certain that Mrs. Siddons scored a triumph as Lady Randolph. Amid the tragedies at the beginning of the last half of the eighteenth century, two stand forth distinctly. In The Gamester, Moore continued Lillo's tendency toward prose realistic tragedy. In Douglas, Home struck a note of romantic tragedy which seems premonitory of the romantic movement late in the century.

The classical tragedies of William Mason (I7241797) belong, in a sense, to literary rather than to dramatic history. Yet their ultimate, though longdelayed, production at Covent Garden entitles them to some consideration here. Mason was one of the Cambridge set of 'polite scholars' among whom was numbered his friend, Thomas Gray. His classical tastes found expression in his dramatic poem Elfrida, published in $\mathbf{I 7 5 2}^{2}$. Twenty years later, without the author's consent, George Colman altered it for the stage with sufficient success to justify more than a score of performances. Not content with Colman's version, Mason himself revised the piece for a later production (1779), also at Covent Garden. Caractacus, 'Written on the Model of The Ancient Greek Tragedy,' printed in 1759 , was acted, with the author's revisions, in 1776 , fourteen times. Mason's classical tragedies are more noteworthy for form than for substance. He built on the lines of Greek tragedy, with deference to the dramatic unities and to the classical distaste for violent action, and with a fondness for the introduction of Greek choruses which his own 
alterations for the stage recognize as unwise. His "verse shows the influence of Milton and Gray, but at best reproduces external form without poetic content. Yet his dramatic shortcomings are those of his age. Not the play, but the player dominated the Garrick era. 


\section{CHAPTER XV}

THE LIGHTER DRAMA OF THE GARRICK ERA

THE general poverty of original English drama during the mid-eighteenth century is apparent in comedy as well as in tragedy. A few regular comedies still show the partial survival of the vis comica of earlier drama. Benjamin Hoadley's comedy, The Suspicious Husband ( 1747 ), whose initial run of a dozen successive nights was but the beginning of Garrick's long-continued success in the part of Ranger, became a stock drama. The Jealous Wife, The Clandestine Marriage, and occasional comedies of less significance are welcome proof that the earlier comic tradition did not wholly disappear under the wave of moralized sentiment. It must also be remembered that the comic spirit found constant expression in the stage revivals of earlier masterpieces. The genius of comedy was not dead in an age that knew David Garrick as Abel Drugger in The Alchemist. Yet, for the most part, laughter felt so constrained in the formal limits of five acts that it sought free outlet in the larger license of farce, burlesque, and pantomime.

Throughout the Garrick era, regular drama found constant rivals for popular favour in pantomime, farcical entertainment, and spectacle. After the secession of Barry and Mrs. Cibber to Covent Garden, Garrick reopened his theatre, in September, 1750, 
with a prologue which pronounced Drury Lane sacred to Shakespeare, but declared his willingness to cater to popular demand if Harlequin was preferred to Hamlet and the stage carpenter to the dramatic poet. In point of fact, he produced that season with conspicuous success 'a new Entertainment, in Italian Grotesque characters, called Queen Mab,' with Woodward as Harlequin. Once Garrick even overshot the mark in 'a new grand Entertainment of Dancing called The Chinese Festival' ( 1755 ), an elaborate spectacle 'with new music, scenes, machines, habits, and other decorations,' and a large company of performers. The inclusion of a number of foreign dancers was made the occasion of a series of serious riots, and led to the withdrawal of the piece after its sixth performance.

At Covent Garden, through the ups and downs of his long managerial career, Rich relied on pantomime as his surest support. Upon one of his great successes, Orpheus and Eurydice (1740), he spent about two thousand pounds. This piece, which may sufficiently illustrate the general nature of Rich's entertainments, is part opera and part comedy, and includes among the comic characters in the pantomime Harlequin, Pantaloon, Columbine, Squire Gawky and his mother, and Pantaloon's servant. Its most famous spectacular device was the mechanical serpent whose business was to pierce Eurydice's heel. Rich also made capital out of the revival, in I759, of The Beggar's Opera, which, apart from the interruption of the habitual performance of Rowe's 'Fifth of November play' Tamerlane, ran for thirty-seven consecutive 
nights. Thus, though in a large sense Shakespeare dominated the drama as Garrick did the theatre of the day, their supremacy was resolutely challenged.

The conflict between regular drama and its less dignified rivals was not seldom settled by a practical compromise. As Restoration tragedy had frequently its coarsely comic epilogue, eighteenth-century drama was often capped with a comic afterpiece. Pantomime, burlesque, farce, and operetta proved well adapted for this purpose. Pieces of two or three acts, often so nondescript in character that they are loosely described as 'entertainments,' found ready favour. As this practice of the theatres increased in popularity, even so considerable a play as Sheridan's Critic was produced as an afterpiece. Colley Cibber reluctantly admitted pantomimes 'as crutches to our weakest plays,' and his fellow-manager Booth, with an eye to the box-office, found no harm in an addition to the evening's entertainment which greatly enlarged the audience for regular drama. When the increase of prices on pantomime nights was declared an imposition upon the patrons of regular drama, the Drury Lane management met the objection, as early as 1734 , by allowing 'the advanced money to be returned to those who go out before the Overture of the Entertainment begins' - a custom whose long continuance is presumptive proof that no serious financial loss resulted. ${ }^{1}$ The Drury Lane playbill for 28 December,

1 'It may be questioned if there was a demand for the return of $£_{20}$ in ro years.' Genest, III, 158 . See Genest, III, $441-442$, under date of 14 December, 1734 , as to the return of advanced money. On that occasion Farquhar's Recruiting Officer was followed by a 'Pantomime called Merlin, or the Devil at Stone-Henge.' 
I744, reproduced by Genest, ${ }^{1}$ repeats substantially the same announcement, and will serve as sufficient illustration of the connection between formal drama and the afterpiece in actual stage representation. To the drama for the evening, Steele's Conscious Lovers, was added 'a Pantomime Entertainment call'd Harlequin Shipwreck'd.' It does not seem fantastic to detect a reactionary effect of the afterpiece on the drama itself, for The Conscious Lovers is billed 'with Entertainments' which include 'Singing by $\mathrm{Mr}$. Lowe' in the second act, and at the 'End of Act IV. a Grand Dance by Mr. Muilment, and others.' Examination of many eighteenth-century playbills seems to support the suggestion here ventured that the popular practice of including a pantomime or other afterpiece may have increased the tendency of regular drama to fortify itself with music, dancing, and various other accessories of pantomime and spectacle. That such influences exerted real pressure may be seen in Garrick's retention of operatic features in his production of The Tempest, and in the addition of more than a score of songs and the employment of some Italian singers in the version of Midsummer Night's Dream called The Fairies ( 1755 ), usually ascribed to Garrick and certainly produced under his direction. It may further be suggested that the multiplication of such short dramatic pieces as Fielding's facilitated the practice of including an afterpiece, and that in turn the increased possibilities of stage production encouraged the writing of short theatrical pieces that would serve for passing amusement. In such aspects, 
the custom of the afterpiece concerns more than the theatrical antiquary. It may be said to exercise a real, though not definitely determinable, influence on regular drama.

Most conspicuous among writers of minor drama during the Garrick era is SAMUEL Foote (1720-1777). Though appearing, in 1744 , in the ill-chosen rôle of Othello, Foote soon found his forte in comedy. Like Garrick, he introduced in the part of Bayes mimicry and caricature of his fellow-actors. In April, 1747, evading the Licensing Act by advertising 'a Concert of Musick with which will be given gratis a new Entertainment called the Diversions of the Morning, ${ }^{1}$ Foote established himself at the Little Theatre in the Haymarket. The vein of mimicry already successfully struck was now developed unsparingly in caricature of the lingering accents of Garrick's dying speeches, the 'squeaking pipe' of Mrs. Woffington, and even the physical defect in Delane's eyesight. During the season Foote varied his announcements by inviting his friends 'to come and drink a dish of Chocolate with him' at noon or 'a dish of Tea' at half-past six. For two subsequent seasons the 'Auction of Pictures' was his framework for a set of dramatic sketches, outlined sometimes with general satirical strokes and sometimes with individual touches of caricature. In The Knights (1749), Foote essayed more regular dramatic form, casting his 'comedy' in two acts and, according to the Preface, drawing the 'three principal characters' from life 'in their plain natural habit.' Yet Foote depended largely on his own actor's art 
and somewhat on the addition of a 'Cat's Opera' burlesquing Italian opera.

Foote had found little difficulty in evading the Licensing Act, but he was fortified in I 766 , with the patent obtained through the influence of the Duke of York which entitled him to perform during the summer season, from the middle of May to the middle of September. Though this patent was only for a summer theatre and for Foote's lifetime, it was in reality a grant for a third Patent Theatre. Possessed of powers of caricature which even Doctor Johnson thought dangerous, ${ }^{1}$ and backed by royal license, Foote kept Garrick constantly uneasy at his animosity and jealous of his success. His career as playwright curiously coincides within a few months with Garrick's managership at Drury Lane (I747I776).

As a dramatist, Foote was a direct descendant of Fielding. With him, Fielding's partiality for short theatrical pieces becomes quite consistent practice. Of Foote's printed dramatic works, numbering about a score, none exceeds in length three acts. The personalities, 'local hits,' and contemporary satire of Fielding were developed to the full by this clever mimic who convulsed those whom he did not hold up to ridicule. With Foote, as with Fielding, much of the zest of personal satire is now lost. Taylor, the quack oculist, the Welshman Ap Rice, the extortioner, Mrs. Grieve, the Quaker doctor Fordyce, and so many other passing figures whom Foote delighted to ridicule are now unfamiliar. Even George Faulk-

1 Boswell's Life of Johnson, Hill edition, 1887, II, 299. 
ner, remembered perhaps as Swift's Dublin publisher, is too shadowy to give distinctness to the mockery of him as Peter Paragraph in The Orators ( 1762 ). Doctor Johnson told Boswell ${ }^{1}$ that the fear of broken bones restrained Foote from caricaturing him, but for the most part Foote was no respecter of persons. When $A$ Trip to Calais was so plainly directed at the Duchess of Kingston in the character of Lady Kitty Crocodile that she interfered to secure the suppression of the piece, Foote altered his sketch into The Capuchin ( 776 ), and vented his satire upon her chaplain Jackson in the abusive portrait of Doctor Viper. Sometimes, as in the two farces, The Englishman in Paris (1753) and The Englishman Returned from Paris ( 1756 ), where racial peculiarities are touched, Foote essayed the broader strokes of general satire, but such efforts seem less successful than those that are whetted with the zest of personal caricature.

The modern reader will perhaps more readily appreciate Foote's methods of dramatic satire in The Minor (1760) and The Maid of Bath (I77I). The Minor, though not free from grossness, is in Foote's best vein of ready wit, lively characterization, and telling satire. From Little Transfer, the broker, Sheridan doubtless took the hint for 'little Premium' in The School for Scandal, while Charles Surface is somewhat reminiscent of the improvident young Wealthy, whose father, in the disguise of a German baron, tests his son's character in a fashion that bears some. resemblance to Sir Oliver's methods with his nephews. If Sheridan took freely such suggestions, he had the

$$
1 \text { Ibid., II, } 95 .
$$


dramatic genius which Foote lacked of welding incidents firmly into his plot and giving action to character. The Minor has more dramatic substance than is usual with Foote, yet its chief point is satire of Whitefield and his Methodist followers. Whitefield himself, caricatured as Doctor Squintum, does not actually appear among the dramatis persona, but his precepts are given mock authority in the mouth of Mrs. Cole, whose shameless profession is no obstacle to her conversion to the cult of Whitefield's Tabernacle. In the Introduction, Foote in person explains to Smart and Canker that 'ridicule is the only antidote against this pernicious poison' which he finds in Whitefield, but his resort to the 'comic muse' was in the interest of theatrical success and not of religious reform. In Shift, Tate Wilkinson, the actor who had once dared to mimic Foote on his own stage, was ruthlessly caricatured. With Foote the whirligig of time was sure to bring in his revenges.

The Maid of Bath (I77I) is based on episodes in the earlier life of Elizabeth Linley, the bewitching favourite of the concert stage whose public career ended with her romantic marriage to Richard Brinsley Sheridan. 'The lively little Linnet' is Miss Linley, 'that old fusty, shabby, shuffling, money-loving, waterdrinking, mirth-marring, amorous old hunks, master Solomon Flint' caricatures Miss Linley's elderly admirer Long, and Major Rackett is the notorious married rake, Major Mathews, who later slandered Sheridan and met him in duel. The upshot of Foote's play is that Miss Linnet, setting aside the worldly 
advice of her mother and the propositions of her various suitors, commends herself to the patrons who have welcomed her 'little talents.' Amid the personalities of the piece Foote inserted a puff direct for himself. When Lady Catherine fails to secure from Flint 'a pecuniary acknowledgement for the damage' done to Miss Linnet by his attentions, she says: 'Gad's wull, it sha' cum to the proof: You mun ken; gued folk, at Edinbrugh, laist winter, I got acquainted with Maister Foote, the play-actor: I wull get him to bring the filthy loon on the stage' (III, I). Foote, indeed, was his own prompter in bringing on the stage the local gossip and town tattle of the hour.

Foote's other dramatic pieces follow the general lines already suggested. His satire hit readily at whatever subject was ready to hand - at the credulity of collectors of antiques and of pictures in Taste, at the pretences of authors and their patrons in The Author and The Patron, at the unmartial spirit of the militia in The Mayor of Garratt, at the quackery of doctors in The Devil upon Two Sticks, and at knavery in The Cozeners. Yet such themes served mainly as general framework for living pictures of Taylor, the 'Itinerant Oculist,' of Ap Rice, of Thomas Sheridan, and of other definite personalities of the day. Without the conscious zeal of the reformer or the sympathy that deeply interprets character, Foote turned his satire chiefly to the oddities and eccentricities of society. For the most part, his characters have animation and theatrical effectiveness, but they are exposed rather than developed in action. Action, indeed, with Foote is more apt to be the bustle of 
the stage than the coherent development of dramatic plot. Again and again, dialogue is allowed to wander from the forward path into the meanders of personal gossip, somewhat in the fashion of Aircastle in The Cozeners, a delightful 'humour' character who keeps up a running but aimless fire of speech. Though Foote's pieces are usually printed as 'comedies,' they belong mainly to the realm of farce. Like his own actor's art, they are fond of substituting mimicry for original interpretation of character. There are occasional flashes of comic genius, but more frequently an artificial cleverness. Among the dramatists of his day Foote holds a distinct, if not unique, position, but it is as a cartoonist rather than as a dramatic artist.

The zest of Foote's farces, without their personal sting, is seen in various contemporary afterpieces. Garrick's practical knowledge of the stage helped him to produce successfully a number of lively farces, such as The Lying Valet (I74I), Miss in her Teens (I747), The Irish Widow (I772), and Bon Ton (I775). Perhaps better than any of these is High Life Below Stairs (I759), frequently ascribed to Garrick, but really the work of his friend, Rev. JAMES TownLEY (I7I4-I778). A long career as schoolmaster led finally to Townley's appointment as head-master at the Merchant Taylors' School, where he enlivened the curriculum with some dramatics. His later farces, False Concord ( $\mathrm{I}_{764}$ ) and The Tutor ( $\mathrm{I}_{765}$ ), were less successful. Though High Life Below Stairs is perhaps not so wholly novel in theme as is sometimes asserted, it proved a welcome variety to those who, like George 
Selwyn, were tired of 'low life above stairs.' For the most part, servants had been relegated to the background, but Townley opened the door of servants' hall, as Thackeray did in the Diary of C. Jeames de la Pluche. The brisk farce has considerable action, and leads to a good dramatic situation where the returned master, Lovel, is about to shoot through the door at the supposed cat which has been declared responsible for the noise made by the refugees now in hiding. Faithful Tom, the honest servant, is vindicated in rather conventional fashion, but the spirit and fun of the piece gave it long vitality on the English stage, led to its translation into French and German, and secure for it even to-day occasional hearing.

Among playwrights of the period a place must be accorded to the prolific ARTHUR MURPHY (I7271805). The diversity apparent in his various pursuits as bank clerk, periodical writer, barrister, actor, and playwright, is characteristic also of his wide range of dramatic effort. The Spouter, or The Triple Revenge, published in I756, attributed to Murphy, follows the vein of Fielding's and Foote's personal satires. Hill, Theophilus Cibber, and Foote are the objects of the triple revenge, while Garrick and Rich come in for some satirical strokes. The Upholsterer (I757), a farce that seems indebted to Fielding's Coffee-House Politician, is a general satire of political quidnuncs. From personal and farcical satire Murphy rose to comedy in The Way to Keep Him (I760), expanded the following year from three to five acts, and All in the Wrong (176r), drawn from Molière, plays which held a place on the stage until well into the next 
century. Less successful were his three adaptations from Voltaire previously discussed. The School for Guardians, compounded largely from Molière, is another instance of Murphy's indebtedness to French drama. Of his tragedies, Zenobia ( 1768$)$ and The Grecian Daughter ( 1772 ) sufficiently illustrate his adherence to the remote unrealities of classical drama. The initial success of The Grecian Daughter was largely due to the Barrys, but its theatrical fame rests more securely upon the tradition of Mrs. Siddons in the rôle of Euphrasia.

In many ways, Arthur Murphy may be taken as a fair representative of the ordinary drama of his period. He was content to cast his plays in the conventional mould, and to draw his materials from sources as obvious, and yet as varied, as Fielding's farces, Molière's comedies, and Voltaire's tragedies. In comedy he sounded the familiar didactic note, schooling wives in 'the way to keep' their husbands, and husbands in the lesson that constancy should not be shamefaced. In tragedy he struck the conventional chords. Yet, with sufficient theatrical sense to follow industriously the fashions which he had not the originality to lead, he won a considerable measure of popular favour. His dramas lack distinction and individuality, but are not without ingenuity in adaptation of materials to his purposes. His dramatic aim may have been higher than that of Fielding or Foote, but none of his comedies leaves so distinct an impression as Townley's less pretentious farce, and none of his tragedies seems so memorable as Fielding's burlesque tragedy, Tom Thumb. 
Another popular Irish playwright of the Garrick period was IsAac BICKERSTAFF ${ }^{1}$ (I 735 circ.-I8I 2 ?). He had a facile hand for opera libretti, giving to Thomas and Sally (I 760) the typical eighteenth-century plot of a villainous squire foiled by the hero in his attempt to seduce the innocent maiden, and taking hints from an earlier opera and from Wycherley's Gentleman Dancing-Master for his Love in a Village (1762). The Maid of the Mill ( 1765$)$, drawn largely from Pamela, and Lionel and Clarissa ( 1768 ) were conspicuous operatic successes for which Bickerstaff supplied the words. In 1768 , he produced at Drury Lane, in successive months, two very popular pieces The Padlock, a musical entertainment which had more than fifty performances, and The Hypocrite, an excellent revision of Cibber's Non-Juror, with the addition of the effective stage character, Maw-worm. With little creative dramatic power, Bickerstaff had considerable facility in adaptation and practical knowledge of theatrical effects.

The mediocrity of playwrights like Murphy and Bickerstaff enhances by contrast the far more noteworthy comic achievement of GeORge Colman, THE EldER (1732-r794). In his best work are traces of the earlier and more genuine comic spirit which had been largely lost as drama had become sentimentalized. His father, envoy at the court of Tuscany, died the year after his son's birth at Florence. Educated by

1 The name is frequently spelled 'Bickerstaffe.' His plays were habitually published anonymously, but The Romp (1786), gives his name as 'Bickerstaff,' and this is the spelling in the Garrick Correspondence. 
his uncle who urged him, after his course at Oxford, to follow the law, and prodded by his aunt toward the ministry, his own taste turned toward literature. By I 760 he had won reputation as a man of literary taste and discernment, and had made friends with Garrick. Conscious of his uncle's dislike for his dramatic tendencies, Colman produced his first dramatic venture, Polly Honeycombe (I760), anonymously. Slight as is this popular afterpiece, it merits unusual attention as a reaction against the sentimental school and as a forerunner of Sheridan's Rivals. The satire directed in the Prologue against the sentimental novel foreshadows the opening scene where Polly bids her Nurse 'call at the Circulating Library' for the novels of the day - a scene which inevitably recalls Lydia Languish's introductory conversation with Lucy about the novels of the circulating library. The exclamation of Polly's father, 'A man might as well turn his daughter loose in Covent-Garden, as trust the cultivation of her mind to a circulating library,' suggests Sir Anthony Absolute's more finished dictum, 'A circulating library in a town is as an evergreen tree of diabolical knowledge.' Like Lydia Languish, Polly thinks of 'ladders of ropes' and other accessories of sentimental elopements. In Polly Honeycombe, Colman anticipates the laugh which Sheridan was to turn against sentimentality.

The Jealous Wife ( $76 \mathrm{r}$ ), deservedly the most popular comedy of its day, is essentially a dramatization of Tom Jones. Tom Jones becomes Charles Oakly; Sophia, Harriot; Lady Bellaston, Lady Freelove; Lord Fellmar, Lord Trinket; Squire Western, Russet; 
Blifil, Beagle, with an effective transfer to him of Squire Western's sporting instincts. Mr. and Mrs. Oakly are not in Tom Jones. Numerous situations in the novel and the play are identical, and from the novel are taken the use of the press-gang, the challenge for the duel, and Charles's intoxication. Further questions as to the sources of the play are comfortably settled by Colman's statement in the 'Advertisement' that he took 'some hints' from the Spectator, a suggestion from the Adelphi of Terence, and advice from Garrick. Colman, however, deserves full credit for his skill in welding his materials into effective drama.

The Jealous Wife is strongly reminiscent of Restoration comedy, without the unhealthiness of its moral atmosphere. Lord Trinket's French phrases have the familiar Gallic affectation, and Lady Freelove suits her action to her name in the fashion of the Restoration. She exhibits the habitual contempt for the country and the preference for good manners over good morals. Sir Harry Beagle's rough love-making to Harriot (IV, 2) recalls sailor Ben's love-making in Congreve's Love for Love (III, 3), with the substitution of the lingo of the stable for that of the sea. ${ }^{1}$ The plot is dramatically effective, the situations ingenious. The scene where Mrs. Oakly overhears her husband and Harriot, and then, with Russet's vigorous aid, accuses the innocent Oakly (end of Act III) is an excel-

1 Though the spirit is closer than the phraseology, Sir Harry's 'Look'ye, Miss, I am a Man of few Words' is comparable with Ben's 'How say you, mistress? The short of the thing is, that if you like me, and I like you, we may chance to swing in a hammock together.' 
lent illustration of stage effectiveness. The action does not flag, and its two plots are skilfully united by Harriot's flight to Oakly's house which arouses the suspicions of the jealous wife. The final solution remains in doubt for a time, as it seems uncertain whether Oakly will assert himself enough to dominate his wife. Eventually, however, with somewhat of Petruchio's manner, he tames his wife's spirit.

Charles Oakly is the hero, the familiar type of easy morals and successes in love. Tom Jones is his confessed original, and Charles Surface his best known descendant. Harriot is Fielding's Sophia, with somewhat of Richardson's Pamela. Lord Trinket slightly recalls Richardson's Lovelace. Captain O'Cutter, an ancestor of Sir Lucius O'Trigger, is distinct, but his dialect is a doubtful experiment. Without the strength of character drawing of Wycherley or Vanbrugh, and without Congreve's finish and epigrammatic wit, The Jealous Wife is a distinct comedy success.

During the next two years, Colman produced two successful afterpieces, The Musical Lady and The Deuce is in Him, and an alteration of Philaster ( 1763 ) in which Powell, the tragedian, made no less than sixteen appearances during the season. Such theatrical successes, it must be remembered, do not necessarily imply much dramatic power, for in the season of $1762-176_{3}$ Garrick's most frequent appearances in tragedy were as Don Alonzo, in Mallet's Elvira, and in comedy as Sir Anthony Branville in Mrs. Sheridan's Discovery, a play whose chief significance to the modern reader is probably that it was written by the mother of Richard Brinsley Sheridan. With the col- 
laboration of Garrick, however, Colman, rose again to genuine comedy in The Clandestine Marriage (I766).

The germ of The Clandestine Marriage was one of Hogarth's plates in his Marriage-d-la-Mode. The characters of Lord Ogleby, Sterling, and Brush, together with a considerable amount of dialogue, are said to have been taken from Townley's farce, False Concord, but in any event their success came only with transfer into a vital drama. Lord Ogleby, at least, becomes a notable stage character, a survivor of the famous Restoration family which included Sir Fopling Flutter, Sir Novelty Fashion, Sir Courtly Nice, and Lord Foppington. In the 'character part' of Mrs. Heidelberg some have been insistent in discovering the original of Mrs. Malaprop, but there is a decided difference between her mispronunciation and Mrs. Malaprop's 'select words so ingeniously misapplied, without being mispronounced.' The very palpable hits in the dialogue at the artificiality of eighteenth-century landscape gardening ${ }^{1}$ suggest that the play itself breaks over the dull formalities of the mechanical comedy of the period. At times the poverty of comic spirit before Goldsmith and Sheridan has been exaggerated into too positive insistence upon

1 Sterling declares (II, I): 'You must see my water by daylight, and my walks, and my slopes, and my clumps, and my bridge, and my flow'ring trees, and my bed of Dutch tulips.' Lord Ogleby (II, 2) finds that in Sterling's garden 'the four seasons in lead, the flying Mercury, and the basin with Neptune in the middle, are all in the very extreme of fine taste. . . . A most excellent serpentine. . . forms a perfect maze, and winds like a true lover's knot ... One can hardly see an inch beyond one's nose any where in these walks.' 
its extinction. With The Jealous Wife and The Clandestine Marriage, it is unnecessary to invoke the aid of farces like Foote's, to prove that the comic spirit was not dead. Without belittling the importance of Goldsmith's service to English comedy, it is idle to maintain that he was the first to turn comedy back from tears to laughter.

The Clandestine Marriage led to a quarrel between its authors over Garrick's refusal of the rôle of Lord Ogleby. The breach was widened when Colman, with Powell, Harris, and Rutherford, purchased the Covent Garden Theatre. Managerial disputes between Colman and Powell on the one hand, and Harris and Rutherford on the other, led to Colman's retirement in I774. During the seven years of his management at Covent Garden had been produced Goldsmith's Good Natur'd Man, and She Stoops to Conquer, ${ }^{1}$ a revival of Cymbeline, a version of King Lear, with Colman's alterations, and some minor work of his own. After his retirement and reconciliation with Garrick, the latter produced for him a two-act comedy and a version of Ben Jonson's Silent Woman. After the transfer by Foote to Colman of the Haymarket Theatre, Colman produced some of his own minor pieces. A member of the Literary Club, a successful dramatist and manager, a translator of the comedies of Terence, an editor of the dramatic works of Beaumont and Fletcher, a writer of prologues and epilogues, among them the Epilogue to The School for Scandal, George Colman the elder was a notable figure in the

1 The obstacles put by him in Goldsmith's path entitle Colman to little credit for the production of these plays. 
Xv LIGHTER DRAMA OF THE GARRICK ERA 263

theatrical and literary world of the last half of the eighteenth century. The latter part of his career exceeds the limits of the Garrick era, but The Jealous Wife and The Clandestine Marriage preserve the comic spirit until the advent of Goldsmith and Sheridan. 


\section{CHAPTER XVI}

THE RISE AND HEIGHT OF SENTIMENTAL DRAMA

Sentrmental drama, foreshadowed in the pathetic appeal of Otway and Southerne in tragedy, and carried into comedy by Cibber and Steele, rose to its height in the Garrick era. The vein of sentiment exploited by Steele had run thin with his successors, passing at length into the crude ore of sentimentality. On the Continent, comedy, which had admitted a serious undertone in Destouches and a pathetic strain in Marivaux, saw sentiment turn into tears in Nivelle de la Chaussée. The drame sérieux, or comédie bourgeoise and the comédie mixte led to the comédie larmoyante. The birth of the sentimental novel fostered the tendency of comedy to substitute tears for laughter. Richardson directly inspired La Chaussée's Paméla (I743) and even Voltaire's Nanine (I749). ${ }^{1} \quad$ To these more serious tendencies of French drama the plays of Diderot, strongly influenced by Lillo's bourgeois tragedy, contributed during the third quarter of the eighteenth century. The very term drame suggests the obliteration of the rigid line between comedy and tragedy. In England, the kinship between sentimental comedy and tragedy is discernible even as early

1 Voltaire's Preface, however, declares that, though 'melting pity' is admissible, comedy without the comic element 'would be a very faulty and very disagreeable species.' 
as Steele in the pathetic note which links his sentimental comedies backwards to the tragedies of Otway and Southerne. Both in France and in England, Thalia was not ashamed to hide her head on the shoulder of Melpomene.

Sentimental drama did not develop without some protest. Gay, Fielding, and Carey burlesqued on the stage some of its artificialities. Even after he had abandoned drama for the novel, Fielding struck a passing blow at sentimental comedy in his description in Tom Jones ${ }^{1}$ of the puppet-show of The Provoked $H$ usband as a 'very grave and solemn entertainment, without any low wit, or humour, or jests,' in which there was not 'anything which could provoke a laugh.' The word 'low' became the usual brand with which advocates of the sentimental drama stigmatized comedies that stooped to conquer with so mean a weapon as the laugh of ridicule. 'By the power of one single monosyllable,' wrote Goldsmith ${ }^{2}$ with almost a presentiment of the criticism which within a decade was to demand the excision of the bailiffs' scene from his own comedy, 'our critics have almost got the victory over humour amongst us. Does the poet paint the absurdities of the vulgar; then he is low; does he exaggerate the features of folly, to render it more thoroughly ridiculous, he is then very low. In short, they have proscribed the comic or satyrical muse from every walk but high life, which, though

1 Book XII, Chapter V.

2 The Present State of Polite Learning, 1559 edition, p. 154, quoted by Austin Dobson, Belles-Lettres edition of Goldsmith's plays, Introduction, pp. xiii-xiv. 
abounding in fools as well as the humblest station, is by no means so fruitful in absurdity.' Sentimental comedy was dignified by its admirers with the aristocratic term 'genteel.' Against its tyranny of tears murmurings were distinctly audible, but it maintained its dominance until it had to yield to the comedy of Goldsmith and Sheridan.

What was sentimental comedy in the Garrick era? This question may perhaps best be answered by defining its general character and by examining some of its most conspicuous products. It would be difficult to find a clearer exposition of its general character than that put forth by Goldsmith in his noteworthy Essay on the Theatre; or, A Comparison between Laughing and Sentimental Comedy (I772). ${ }^{1} \quad$ After enforcing Aristotle's definition of comedy as 'a picture of the frailties of the lower part of mankind, to distinguish it from tragedy, which is an exhibition of the misfortunes of the great,' Goldsmith proceeds: 'Yet notwithstanding this weight of authority, and the universal practice of former ages, a new species of dramatic composition has been introduced, under the name of sentimental comedy, in which the virtues of private life are exhibited, rather than the vices exposed; and the distresses rather than the faults of mankind make our interest in the piece. These comedies have had of late great success, perhaps from their novelty, and also from their flattering every man in his favourite foible. In these plays almost all the char-

1 Published in the Westminster Magazine, December, 1772. A convenient reprint may be found in Austin Dobson's edition of The Good Natur'd Man and She Stoops to Conquer in the Belles-Lettres Series. 
acters are good, and exceedingly generous; they are lavish enough of their tin money on the stage; and though they want humour, have abundance of sentiment and feeling. If they happen to have faults or foibles, the spectator is taught, not only to pardon, but to applaud them, in consideration of the goodness of their hearts; so, that folly, instead of being ridiculed, is commended, and the comedy aims at touching our passions without the power of being truly pathetic. In this manner we are likely to lose one great source of entertainment on the stage; for while the comic poet is invading the province of the tragic muse, he leaves her lovely sister quite neglected. Of this, however, he is no way solicitous, as he measures his fame by his profits.' Towards the end of this short essay Goldsmith turns from direct argument to satire: 'But there is one argument in favour of sentimental comedy, which will keep it on the stage, in spite of all that can be said against it. It is, of all others, the most easily written. Those abilities that can hammer out a novel are fully sufficient for the production of a sentimental comedy. It is only sufficient to raise the characters a little; to deck out the hero with a riband, or give the heroine a title; then to put an insipid dialogue, without character or humour, into their mouths, give them mighty good hearts, very fine clothes, furnish a new set of scenes, make a pathetic scene or two, with a sprinkling of tender melancholy conversation through the whole, and there is no doubt but all the ladies will cry, and all the gentlemen applaud.' The testimony of Goldsmith cannot be dismissed simply as that of a hostile partisan, for exami- 
nation of the sentimental comedy which he attacked will support the essential sanity of his verdict.

Sentimental comedy rose to its height in the work of Hugh Kelly and Richard Cumberland. HugH KELLY (I 739-I 777), son of a tavern-keeper in Dublin, turned from early apprenticeship as a staymaker to the life of a literary hack in London. Essays, a successful novel, theatrical criticisms, and a work in the popular style of Churchill's Rosciad paved the way to dramatic efforts. False Delicacy (1768) was produced at Drury Lane six days before Goldsmith's Good Natur'd Man finally achieved its belated production at Covent Garden. It was the clash of sentimental comedy with an upstart rival, and for the moment victory rested with the established favourite. Garrick, who had not forgotten Goldsmith's outspoken strictures in The Present State of Polite Learning on the managerial policy of the theatre, lent his influence to Kelly, fortifying his piece with prologue and epilogue, possibly touching some parts of the play with his practised hand, and forestalling Goldsmith by securing for Kelly the advantage of first hearing. In contrast with the moderate favour accorded at the outset to Goldsmith's piece, Kelly's 'genteel' comedy won a theatrical triumph. On the morning after the appearance of the first edition, appropriately dedicated to Garrick, the publisher announced that three thousand copies had been sold before two o'clock. By the end of the season the sales reached ten thousand copies. The play was translated into German, French, and Portuguese, and acted at Lisbon and Paris to crowded houses. Kelly had struck the 
popular chords of sentiment and the response was immediate.

False Delicacy is a comedy of cross-purposes. Three sets of mismated lovers are entangled in a web of misunderstanding so transparent that it would break at a ruder touch than that of a sentimentalist. False delicacy forbids the various lovers to speak the truth, and the course of sentimental love never would run smooth without the intervention of the bluff Cecil and the practical matchmaker Mrs. Harley. Upon the artificial framework of a plot whose improbabilities would suggest farce if they were not treated seriously is imposed the didactic moralizing dear to sentimental comedy. A few speeches, taken almost at random from different characters and in different situations, will show the prevalent tone. Says Lady Betty (II, 2) 1 : 'The woman that wants candour where she is address'd by a man of merit, wants' a very essential virtue; and she who can delight in the anxiety of a worthy mind, is little to be pitied when she feels the sharpest stings of anxiety in her own.' Says Miss Rivers (IV, 2): 'An elopement even from a tyrannical father, has something in it which must shock a delicate mind. - But when a woman flies from the protection of a parent, who merits the utmost return of her affection, she must be insensible indeed, if she does not feel the sincerest regret.' Says Sidney $(V, I)$ : 'There is something shocking in a union with a woman whose affections we know to be alienated; and 'tis difficult to say which is most entitled to contempt,

${ }^{1}$ Scene-divisions are not always clearly indicated either in the 1768 octavo of False Delicacy or in the 1778 edition of Kelly's Works. 
he that stoops to accept of a pre-engaged mind, or he that puts up with a prostituted person.' Says Winworth $(\mathrm{V}, 2)$ : ' $\mathrm{He}$ is the best manager of a fortune who is most attentive to the wants of the deserving.' The last speech of Rivers may be taken as the golden text of the play: 'But the principal moral to be drawn from the transactions of to-day is, that those who generously labour for the happiness of others, will, sooner or later, arrive at happiness themselves.' In one of Winworth's speeches $(\mathrm{V}, 2)$ may be found the expression of Kelly's own attitude to the stage: 'The stage shou'd be a school of morality; and the noblest of all lessons is the forgiveness of injuries.' 'The stage should be a school of morality' - that, indeed, was the creed of sentimental drama. It was the very phrase that Sheridan, in The Critic, turned ironically against sentimental drama when he made Sneer exclaim: "The theatre, in proper hands, might certainly be made the school of morality; but now, I am sorry to say it, people seem to go there principally for their entertainment!'

Although False Delicacy is essentially a sentimental comedy, justice must recognize Kelly's partial alleviation of the distresses of sentimentality. Mrs. Harley and Cecil give comic relief to the dead level of sentiment which forms the usual staple of dialogue. 'Thank heav'n,' cries Mrs. Harley, 'my sentiments are not sufficiently refin'd to make me unhappy'(II, I). If she had a chance to secure an eligible successor to her two previous husbands, she 'would make sure work of it at once, and leave it to your elevated minds to deal in delicate absurdities ' (IV, I). When Miss 
Marchmont declares she is willing at last to accept Lord Winworth, wrongly thinking that this will please Lady Betty, her protectress, Mrs. Harley ejaculates : 'Now will I be hang'd if she does not undo every thing by a fresh stroke of delicacy,' and again, ' $O$ the devil take this elevation of sentiment!' and still again, 'Did ever two fools plague one another so heartily with their delicacy and sentiment?' Cecil, like Mrs. Harley, is frankly contemptuous of delicacy and sentiment. 'What a ridiculous bustle is there here,' he breaks out in the last act, 'about delicacy and stuff your people of refin'd sentiments are the most troublesome creatures in the world to deal with, and their friends must even commit a violence upon their nicety before they can condescend to study their own happiness.' The very title of Kelly's comedy is, in fact, evidence that sentimental delicacy may be carried to false extremes. Yet with every allowance of non-sentimental elements in Kelly's work, it remains indisputable that the primary appeal of the dramatist is to sentimental emotion. The chief personages voice their sentiments and emit their moral platitudes in sober earnest and with a reformer's zeal. Their speeches are without the irony with which Sheridan turned sentimental rant to hypocritical cant in the mouth of Joseph Surface. Kelly cared more to point a moral than to adorn his drama. Even false delicacy does not prevent the blessings of comedy from descending at last upon its sentimental children and dismissing them with a dower of didactic aphorisms. With False Delicacy the stage has become a school of morality. 
Kelly's next comedy, $A$ Word to the Wise (I770), was crushed by the hostile attacks of his political foes, and his tragedy, Clementina ( $\mathrm{I} 77 \mathrm{I}$ ), by its own weight. Mindful of his enemies, Kelly produced, under the friendly name of Addington, $A$ School for Wives (I 773), a comedy whose continued success soon defied opposition. The utter failure of The Man of Reason ( $\mathrm{r} 776$ ) caused him to give up playwriting.

The leadership of sentimental drama may be said to have been shared between Hugh Kelly and SIR Richard Cumberland (I732-I8II). Yet to-day Cumberland lives less as a dramatist than as the Sir Fretful Plagiary of Sheridan's Critic. Cumberland's own Memoirs and letters unconsciously prove that Sheridan portrayed to the life the dramatist whom Garrick called a 'man without a skin.' ${ }^{1}$ It is not surprising that his tender sensibilities found congenial employment in the writing of sentimental drama. Mathematical honours won at Cambridge and various posts held under Lord Halifax seemed to promise a successful political career. But when Lord Halifax became Secretary of State, Cumberland's hopes of an under-secretaryship were not realized. Earlier in life he had written, besides a play upon Caractacus, The Banishment of Cicero, which, though declined by Garrick, was published in $176 \mathrm{r}$. A musical comedy, The Summer's Tale ( 1765 ), acted with some success, encouraged Cumberland to essay comedy. The Brothers ( 1769 ) had more than a score of performances that season and paved the way for the con-

1 Memoirs of Richard Cumberland. Written by himself, I, 347. 
spicuous success of The West Indian ( $177 \mathrm{I}$ ). The sentimental hero, young Belcour, is pictured as 'a heart beaming with benevolence, an animated nature, fallible indeed, but not incorrigible.'1 About him clings a sort of romantic glamour. He returns to London from the West Indies the inheritor of a vast estate from his grandfather, who believed him to be a foundling left at his daughter's house in Jamaica. In reality Belcour was her son, and Stockwell, the merchant to whom the young heir betakes himself in London, is his father. The hero's fallibility appears in his base design upon Louisa Dudley, daughter of a retired captain. Her brother Charles has been rejected by Lady Rusport on the score of poverty. Lady Rusport's estate, however, belongs rightly to Charles Dudley, and she bribes her lawyer to destroy the will which discloses the truth. From such melodramatic premises it is easy to derive the conclusion. The scheming landlady who is responsible for Belcour's attempts upon Louisa is foiled and the benevolent heart of the hero is rewarded with Louisa's hand. Major O'Flaherty, an Irish officer, who may have given Sheridan some hints for Sir Lucius O'Trigger, ${ }^{2}$ discloses the secret of the will, and Charles Dudley and Miss Rusport come into their own. With the departure of the baffled Lady Rusport and Stock-

'Stockwell's final speech (V, 8), I771 edition, p. I02.

O'Flaherty's objection to an explanation of the quarrel to the intending duellists $(\mathrm{V}, \mathrm{I})$, 'Out upon it, what need is there for so much talking about the matter; can't you settle your differences first, and dispute about 'em afterwards?' at least suggests O'Trigger's 'The quarrel is a very pretty quarrel as it stands - we should only spoil it, by trying to explain it.' 
well's disclosure that he is Belcour's father, the curtain falls with the double sentiment of united love and reunited family affection. If Belcour reminds one somewhat of Tom Joi $\ldots$, Cumberland uses him to point the lesson that sentiment has more than its own reward.

The Fashionable Lover ( 1772 ), a sentimental comedy to which its author showed strong partiality, reproduces many of the characters and situations of The West Indian - virtuous beauty under the treacherous care of a designing woman, the baffled intriguer ultimately reformed, property misappropriated, treachery unmasked, and sentimental love comfortably cemented by the restoration of fortune. Comedies such as these represent Cumberland at the height of his dramatic success before the storm had broken in full force upon sentimental drama. Throughout the century and through the first decade of the nineteenth century, Cumberland remained a prolific playwright. Among some fifty dramatic pieces are comedies like The Jew (I794) and The Wheel of Fortune ( 795 ), which continue to rescue distressed virtue from moral or pecuniary vicissitudes, heavy tragedies like The Battle of Hastings ( 1778 ), various adaptations, and numerous pieces which happily escaped print.

Like Kelly, Cumberland consciously sought to make the stage a school of morality. Even after Sheridan had attacked 'the sentimental Muse,' there were not wanting critics to whom the cause of Cumberland was identified with the cause of morality. A communication to The Gentleman's Magazine, February, 
I778, entitled 'Animadversions on the Moral Tendency of The School for Scandal,' defends Cumberland in significant fashion: 'It has been said that this is a second attempt to destroy the taste for sentimental comedy revived by Mr. Cumberland. It will be readily acknowledged, that the plays of that gentleman may tend to produce an affectation of sentiment; but it is better to affect sentiment than vice: and $\mathrm{Mr}$. Cumberland has judiciously executed the whole duty of an author, which is, not only to paint nature, but to paint such parts of it, as every good man would wish to see imitated.' It is not difficult to see wherein lay Cumberland's strength when sentimental comedy was at its height, since not even The School for Scandal could laugh out of countenance the ultra-moralists. Yet, in reality, Cumberland's own Belcour is reclaimed from quite as flagrant youthful errors as those of Charles Surface, and his heart beams with no greater benevolence than that of Sheridan's 'fallible, but not incorrigible' hero. Cumberland has the sentimental dramatist's lack of differentiation of character. He invests the good with a moral halo, and stamps the bad with the mark of Cain. For power of character he substitutes strength of sentiment, and for truth to nature an artificial manipulation of circumstance. The 'happy endings' of Cumberland's sentimental plays are not the logical outcome of natural comedy but are achieved by a tour de force of moralized melodrama. Dramatic probability, as well as mirth, is sacrificed on the altar of sentiment. Sentimental drama, which was ready to borrow from tragedy its pathetic appeal, did not hesitate to capture destiny 
with the enchanted bridle of sentiment. It was master of its own fate, for it not merely caused the sun to shine on the good and the rain to fall on the unjust, but it made temporal prosperity the handmaiden to morality. 


\section{CHAPTER XVII}

\section{GOLDSMITH AND THE REACTION IN COMEDY}

WhILE sentimental comedy was attaining its bad eminence in the plays of Kelly and Cumberland, the forces of reaction found a powerful leader in Oliver GoLdSMITH (I728-I774). In The Present-State of Polite Learning (1759), Goldsmith had indignantly resented the dominance of 'genteel comedy.' In The Good Natur'd Man (I 768), he put into actual practice his theory as to the proper function of genuine comedy. Doubtless his hostility toward sentimental comedy was intensified by the vexatious delays which thwarted his attempts to have Garrick produce his piece, and finally by Garrick's evident determination to have Hugh Kelly's False Delicacy overshadow The Good Natur'd Man. Goldsmith's belated comedy was eventually produced by Colman at Covent Garden Theatre, 29 January, I768. Its moderate success proved that neither the gloomy forebodings of the manager and actors nor the high hopes of the author were fully justified. ${ }^{1}$ In the hands of Shuter and Woodward, Croaker and Lofty were successful parts. Yet Powell failed to animate the rôle of hero, and the false delicacy of a sentimental audience could not brook the descent of comedy to a scene so 'low' as that of the bailiffs. The discussion which had been

${ }^{2}$ The tenth performance was on 21 March. Genest, V, 204. 
waged before the production of the piece as to the inclusion of the bailiffs' scene ended, after the actual test, in its being 'retrenched.' 1

The Preface to the printed edition of The Good Natur'd Man is not too brief to indicate Goldsmith's attitude toward sentimental drama and his own intention in comedy. 'When I undertook to write a comedy,' he begins, 'I confess I was strongly prepossessed in favour of the poets of the last age, and strove to imitate them. The term, genteel comedy, was then unknown amongst us, and little more was desired by an audience than nature and humour in whatever walks of life they were most conspicuous. The author of the following scenes never imagined that more would be expected of him, and therefore to delineate character has been his principal aim.' In discussing his restoration, in the printed text, of the bailiffs' scene which had been 'retrenched' in the representation 'in deference to the public taste, grown of late, perhaps, too delicate,' he expresses the hope 'that too much refinement will not banish humour and character from our's, as it has already done from the French theatre. Indeed the French comedy is now become so very elevated and sentimental that it has not only banished humour and Moliere from the stage, but it has banished all spectators too.' Despite protestation that 'upon the whole, the author returns his thanks to the public for the favourable reception' of his play, Goldsmith fails to disguise his disappointment at the imperfect success of his comedy and his

1 This scene was, however, included in the printed edition, and was restored 'by particular desire,' 3 May, 1773. Genest, V, 372. 
impatience with the continu popularity of sentimental drama. Yet the temporary victory of Hugh Kelly was but natural. While he sailed triumphantly with the favouring tide of sentiment, Goldsmith encountered adverse currents.

If contemporary criticism of The Good Natur'd Man was unduly severe, recent criticism has sometimes erred on the side of leniency. Judged by the test of modern stage revival, ${ }^{1}$ Goldsmith's earlier comedy sustains no such comparison with She Stoops to Conquer as may be made between The Rivals and The School for Scandal. Croaker and Lofty remain excellent character parts, and the dialogue, though often laboured, is touched with Irish humour, but perhaps only the bailiffs' scene, Lofty's entrance, and Croaker's reading of the letter seem genuinely effective. Neither in dramatic construction nor in characterization has Goldsmith fully developed his latent dramatic strength. Too much of the mechanism of plot is left crudely exposed to view. Especially clumsy is the scene in which Leontine and Olivia recount the events that have led to their flight from France and have involved them in an artificial maze of circumstance. Their dialogue is so obviously achieved for the benefit of the audience that it recalls Dangle's innocent query, in Sheridan's Critic, as to the opening dialogue in Puff's tragedy: 'Mr. Puff, as he knows all this, why does Sir Walter go on telling him?' and Puff's rejoinder: 'But the audience are not supposed to know any thing of the matter, are

${ }^{1}$ It was revived by the Yale University Dramatic Association in 1903. 
they?' Goldsmith's very lines betray an uneasy consciousness of some of the improbabilities upon which the situation is made to rest. Leontine has been 'sent to France to bring home a sister,' but has substituted his sweetheart, Olivia. With an evident sense of obligation to account for the complete success of this deception, he remarks: 'My sister, you know, has been with her aunt at Lyons, since she was a child.' A single letter from France would obviously disclose all. Accordingly, Leontine is forced to explain that 'her aunt scarce ever writes, and all my sister's letters are directed to me.' But there are other improbabilities besides those in exposition of plot. The butler who is 'drunk and sober ten times a day' seems hardly in place even in the easy-going household of Young Honeywood, and his drunken eccentricities of speech and conduct suggest farcical exaggeration. The most effective characters, Lofty and Croaker, are essentially 'humour' characters, and Croaker's apprehensiveness of trouble seems rather overdone. The weakness of the amiable hero does not fully excuse his colourless portrayal. Young Honeywood has neither the vivacity nor the individuality of Charles Surface. Nor is such criticism too severe, since Goldsmith professed that his 'principal aim' was 'to delineate character.' In contrast with the sentimentalities of contemporary comedy, The Good Natur'd Man undeniably merits generous recognition. Yet, judged by Goldsmith's own standard of later achievement, it is a tentative dramatic experiment. If the touch of a master is at times discernible, there yet remain many marks of an apprentice hand. 
The real difference between The Good Natur'd Man and the sentimental comedies of the period lies perhaps rather in general atmosphere than in the handling of plot and character. The mawkish excesses of sentimentality give way to healthier sentiment and heartier comic energy. There are flashes of Goldsmith's Irish humour as when, to Leontine's remonstrance, 'An only son, sir, might expect more indulgence,' Croaker rejoins, 'An only father, sir, might expect more obedience' (I, I). In the excellent scene where Honeywood tries to pass off as officers the bailiffs who have just arrested him, he parries Miss Richland's embarrassing thrust, 'The gentlemen are in the marine service, I presume, sir?' with unusual dexterity: 'Why, madam, they do - occasionally serve in the Fleet, madam!' Yet, despite the usual buoyancy and hearty spirit of the play, it is not difficult to find evidence of the unconscious influence of conventional drama upon even such a reactionary against sentimentality as Goldsmith.

Young Honeywood, the 'good-natur'd, foolish, open-hearted' hero, whose faults - at least to faithful Jarvis - 'are such that one loves him still the better for them,' has traits of Tom Jones which have been seen in Kelly's sentimental hero and some phrases of sentimental diction. Under the doleful contagion of Croaker, he lapses in the opening scene into gloomy aphorisms, terminating a soliloquy on his hapless fate with a sigh, and at the final curtain he draws a moral from the error of his ways. Sir William Honeywood, the benevolent uncle - an earlier Sir 
Oliver Surface who remains ' for some time a concealed spectator' of his nephew's follies and dissipation cannot resist the temptation that besets superior virtue to moralize on human frailties, and bestows his final benediction with this warning: 'Henceforth, nephew, learn to respect yourself. $\mathrm{He}$ who seeks only for applause from without, has all his happiness in another's keeping.' There is no need to lay undue stress on phrases that hastily precede the final curtain, yet both the moralized ending of The Good Natur'd Man and the surcharged sentiment of the concluding lines of both The Rivals and The School for Scandal show that not even Goldsmith and Sheridan wholly shook off the yoke of sentimental drama against which they were essentially in revolt. Only in She Stoops to Conquer does the genuine comic spirit maintain its triumph over sentimental drama to the very end.

Notwithstanding its significance to the modern observer of dramatic tendencies, The Good Natur'd Man failed, for the moment, to endanger seriously the popularity of sentimental drama. The success of Hugh Kelly's False Delicacy was reënforced by that of Richard Cumberland's West Indian. The battle, however, was not to be decided by the outcome of a preliminary skirmish. The enemy's advantage in numbers and position may have postponed the crucial attack, but did not finally deter opposition. Goldsmith bided his time. In I 77I he was busy with the composition of a new comedy, but not until many months after its completion did he secure the production, on 15 March, I773, of She Stoops to Conquer, 
or The Mistakes of a Night. Despite the friendly offices of Doctor Johnson, Goldsmith's path had been beset with obstacles. Small credit attaches to Colman's ultimate production of a comedy whose advent he had hindered by procrastination and indifference, and whose chances of success he had endangered by predictions of failure. In the admirable dedication of the printed edition of the play to Doctor Johnson, Goldsmith inserted a palpable hit at the faint-heartedness and apathy of his manager: 'The undertaking a comedy, not merely sentimental, was very dangerous; and Mr. Colman, who saw this piece in its various stages, always thought it so. However, I ventured to trust it to the public.' This trust was not misplaced. She Stoops to Conquer proved so popular that Foote acted it during the summer season at the Haymarket, and Colman continued it next season at Covent Garden. To-day it remains as one of the few plays since Shakespeare that hold the stage after the test of more than a century.

The delays that attended its initial production were, doubtless, not so unfortunate as they were vexatious. Meantime, in December, 1772 , Goldsmith had contributed to the Westminster Magazine his notable Essay on the Theatre; or, A Comparison between Laughing and Sentimental Comedy. In it argument and satire combine to press the question 'whether the true comedy would not amuse us more' than 'this species of bastard tragedy' called sentimental comedy. In February, I773, the powerful weapon of burlesque was directed against sentimental comedy 
by the practised hand of Samuel Foote. The Handsome Housemaid, or Piety in Pattens, professed to show how a humble heroine, 'by the mere effects of morality and virtue, raised herself to riches and honours.' In the spirit of Goldsmith's raillery at mankind's 'delight in weeping at comedy,' Foote now declared that 'his brother writers had all agreed that it was highly improper, and beneath the dignity of a mixed assembly, to show any signs of joyful satisfaction ; and that creating a laugh was forcing the higher order of an audience to a vulgar and mean use of their muscles.' In his exordium to the audience, he promised that 'not a single expression shall escape from our mouths that can wound the nicest ear, or produce a blush on the most transparent skin, not even a double entendre from an Irish Widow.' ${ }^{2}$ In thus burlesquing the false delicacies of moralized sentimental drama, Foote helped to prepare the way for the hearty laughter of Goldsmith's comedy.

The main title of She Stoops to Conquer is an adaptation of a line from Dryden, and the subtitle, The Mistakes of a Night, was one of various early suggestions for naming the play. A few weeks before its production, Doctor Johnson wrote to Boswell, 24 February, I773, "The chief diversion arises from a stratagem by which a lover is made to mistake his future father-in-law's house for an inn. This, you see, borders upon farce.' 3 Farcical elements, indeed, are frequent in She Stoops to Conquer. Goldsmith

1 Genest, V, 374-377.

2 W. C. Oulton, The History of the Theatres of London, 1796, I, 21.

'Boswell's Life of Johnson, Hill edition, 1887, II, 205-206. 
has sometimes been defended from the imputation of farce on the ground that he himself actually experienced the mistake to which Johnson referred, but the improbability in plot lies not in the initial error of confusing a private house with an inn, but in the prolongation of the mistake. Mrs. Hardcastle's excessive timidity, likewise, 'borders upon farce' when she fails to recognize that 'Crackskull Common' is, in reality, her own garden, and that the supposed highwayman-is her husband. The story that Sheridan played on Madame de Genlis a trick like Tony's deception of Mrs. Hardcastle may be offset by the more familiar story that Goldsmith, upon his belated arrival at the theatre on the opening night of She Stoops to Conquer, heard 'a solitary hiss at the improbability of Mrs. Hardcastle, in her own garden, supposing her- . self forty miles off on Crackscull common.' 1 Young Marlow's extreme bashfulness hardly accounts for his failure to recognize the mistress in the maid. Nor are Goldsmith's demands upon the credulity of the audience confined to postulates of the plot. The conception of Young Marlow as a lion among maids and a sheep among ladies is pushed beyond natural bounds. There is inconsistency, as Austin Dobson has well pointed out, ${ }^{2}$ in the fact that 'Tony Lumpkin, who in Act IV is so-illiterate as not to be able to read more than his own name in script, is clever enough, in Act I, to have composed the excellent song of The Three Pigeons' - one stanza of which is reminiscent of Latin grammar and classical

1 Forster, Life and Adventures of Oliver Goldsmith, 1848, p. 631 .

2 Belles-Lettres edition of Goldsmith's plays, Introduction, p. xxviii. 
mythology. Such improbabilities in plot and character are more apparent to the reader than to the audience in the theatre, yet, while it would be folly to forget the theatrical effectiveness of exaggeration, it is easy to justify Doctor Johnson's dictum that the play 'borders upon farce.'

Despite the presence of farcical elements, however, She Stoops to Conquer is, in a larger sense, natural comedy. Here is neither the artificial constraint of the conventional comedy of manners, nor the selfconscious diction of sentimental comedy. The atmosphere is like that of The Vicar of Wakefield. The buoyant spirit already heralded in Farquhar's Beaux' Stratagem ${ }^{1}$ finds in Goldsmith free utterance. The fresh air of out-of-doors sweeps through the windows of the old Hardcastle mansion. Mr. Hardcastle himself has the native simplicity and courtesy of a gentleman of the old school. With him sentiment resumes sincerity: 'I love every thing that's old: old friends, old times, old manners, old books, old wine; and, I believe, Dorothy, you'll own I have been pretty fond of an old wife.' The stage direction that bids him take his wife's hand is almost an impertinence. His very failings seem the natural outgrowth of his simplicity. - One turns gratefully from his wife's impatience with his 'old stories of Prince Eugene and the Duke of Marlborough' to the unwavering loyalty of 'honest' Diggory who has laughed these twenty years at his master's 'story of Ould

${ }^{1}$ Goldsmith, it may be noted, makes Miss Hardcastle remark: 'Don't you think I look something like Cherry in the Beaux' Strata. sem ?' (III, I). 
Grouse in the gun-room.' Nowhere, indeed, can Goldsmith's natural humour be more readily observed than by contrasting Diggory with one of Sheridan's witty valets. Captain Absolute's servant Fag is as clever as his master - that is to say, as Sheridan himself. Diggory's humour is as unconscious as that of Dogberry. With him the conventions of society cannot override the laws of nature. Hunger is a primal instinct: 'Whenever Diggory sees yeating going forward, ecod, he's always wishing for a mouthful himself.' If it be heresy to hint a preference for Mr. Hardcastle and honest Diggory as character creations, there is no need to deny Tony Lumpkin his accepted place as Goldsmith's most effective stage character. A country bumpkin, as perhaps his very name implies, and a 'mamma's darling,' Tony Lumpkin is yet the subject of laughter even more than its object. 'This is not altogether fool.' It is not wholly selfishness that prompts his sympathy with the lovers, nor is it the 'Squire's prestige that secures him the head of the table at 'The Three Pigeons.' And if wits must be measured, Tony is quicker to invent the hoax of the Hardcastle 'Inn' than Young Marlow is to detect it. The best of Goldsmith's characters, in fact, are so admirably portrayed that they might stand by themselves, independent of the necessities of plot.

In dramatic presentation of women, Goldsmith seems less effective. In The Good Natur'd Man, Croaker and Lofty overshadow the other characters. In-She-Stoops to Conquer, the title lends a somewhat fictitious importance to the part of the heroine. 
Her effectiveness rests, to a marked degree, with the actress. Miss Hardcastle and Miss Neville mark an advance over Miss Richland and Olivia, but are not sufficiently differentiated. Mrs. Hardcastle, like Mrs. Croaker in the earlier comedy, is overdependent upon farcical appeal. There is, perhaps, a hint of more genuine vitality in Tony's Bet Bouncer, with 'two eyes as black as sloes, and cheeks as broad and red as a pulpit cushion,' than in many of the women whom Goldsmith actually introduces on his stage. Goldsmith might sympathize 'when lovely woman stoops to folly,' but his insight into the springs of her character was not deep. If Miss Hardcastle's wit is nimble enough to stoop to conquer as a barmaid, she might conceivably have had wit enough to prevail in her own person as mistress. Both in plot and in character, then, Goldsmith tends to impose too much on the credulity of his audience. The postulates of his drama often suggest the exaggeration of farce rather than the subtler truth of the 'comédie humaine.'

In dramatic structure, She Stoops to Conquer shows marked improvement over The Good Natur'd Man. Both plays, indeed, are alike in their usual preference for 'expectation' rather than for 'surprise' as the dramatic motive. The opening scene of the earlier comedy reveals Sir William Honeywood's plan to the audience; and the mistakes of a night delude only the dramatis persone. The audience knows that the Hardcastle house is not an inn, that the barmaid is Miss Hardcastle, and that Mrs. Hardcastle is not on Crackskull Common. The concealment of Tony's age, however, seems an artificial device to precipitate 
the final solution. Both plays, in fact, are complicated with improbabilities of plot and incident. Yet in She Stoops to Conquer the exposition is no longer crude, the threads of plot are more firmly knit, and the dramatic interest is more thoroughly sustained through a series of effective stage situations. The various transfers of Miss Neville's jewels are ingeniously contrived to stimulate and to heighten interest in their ultimate fate. Tony's mischievous tricks contribute directly to the development of the plot. Even the alehouse scene, which might find sufficient justification as a background for Tony Lumpkin and as comic relief from the scenes in the Hardcastle house, supplies the misdirection of the travellers which involves them in the mistakes of the night. The continued popularity of She Stoops to Conquer is the most obvious proof of its dramatic effectiveness.

Though Goldsmith's comedy received the 'very kind reception' which Doctor Johnson, even prior to its performance, thought it deserved, its success did not pass unchallenged. A few days after its production, the scurrilous Kenrick, not content with terming The Good Natur'd Man 'water-gruel' and She Stoops to Conquer 'a speaking pantomime,' turned his libel in the London Packet against Goldsmith's private life. Horace Walpole, in a familiar passage, ${ }^{1}$ uttered a patrician remonstrance against Goldsmith's plebeian humour. 'Dr. Goldsmith has written a comedy - no, it is the lowest of all farces. It is not the subject I condemn, though very vulgar, but the execution. The drift tends to no moral, no edification of any kind.

'Letlers of Horace Walpole, Toynbee edition, VIII, 260. 
The situations, however, are well imagined, and make one laugh, in spite of the grossness of the dialogue, the forced witticisms, and total improbability of the whole plan and conduct. But what disgusts me most is, that though the characters are very low, and aim at low humour, not one of them says a sentence that is natural, or marks any character at all.' Happily, the 'power' of that one single monosyllable - 'low' - had waned since the day when Goldsmith had refused to bow down and worship at the altar of 'genteel comedy.' In the alehouse scene of his opening act, he deliberately bandied the epithet which had fastened itself on his former bailiffs' scene back upon his critics. In the comments of the 'several shabby fellows' of 'The Three Pigeons' upon Tony Lumpkin's song more is meant than meets the ear.

First Fellow. The 'Squire has got spunk in him.

Second Fellow. I loves to hear him sing, bekeays he never gives us nothing that's low.

Third Fellow. O damn any thing that's low, I cannot bear it! Fourth Fellow. The genteel thing is the genteel thing at any time. If so be that a gentleman bees in a concatenation accordingly.

Third Fellow. I like the maxum of it, Master Muggins. What, tho' I am obligated to dance a bear, a man may be a gentleman for all that. May this be my poison if my bear ever dances but to the very genteelest of tunes: Water Parted, or the minuet in Ariadne.

It was no longer necessary for Goldsmith to put the question 'which deserves the preference, - the weep r ing sentimental comedy ... or the laughing, and even low comedy?' The whirligig of time had brought in his revenges. 


\section{CHAPTER XVIII}

\section{RICHARD BRINSLEY SHERIDAN}

The dramatic work of Richard BrINSLEy SHERIDAN (175I-18I6) marks at once the height of the reaction against sentimental drama and the most finished achievement of the English comedy of manners. In the warfare with sentimentality Goldsmith was an 'elder, not a better, soldier' than Sheridan. From the deliberate challenge, in the later Prologue to The Rivals, to the authority of 'the Goddess of the woeful countenance - The sentimental Muse,' to the mockery, in The Critic, of the 'edification' derived from the tearful travails of labouring sentiment, Sheridan constantly ridiculed the efforts of 'genteel comedy' to convert the theatre into a 'school of morality.' Yet he was not merely a destructive satirist, but a constructive dramatist. If he disarmed comedy of her weapon of sentiment, he whetted anew for her the sword of incisive wit which had been dulled by long neglect. With a brilliancy of dialogue unmatched in English comedy since Congreve, and with a mastery of dramatic art unrivalled since Elizabethan drama, Sheridan reclaimed the Restoration comedy of manners and purged it of offence.

Sheridan came into possession of drama by natural inheritance. His father, Thomas Sheridan, was by 
turns actor, theatre manager, elocutionist, and lexicographer. His mother, Frances Chamberlaine, produced, in the Memoirs of Miss Sidney Bidulph (I 76I), a novel which won Doctor Johnson's praise, and in The Discovery ( $\mathrm{I}_{63}$ ) a comedy in which Garrick achieved distinct success. Her unfinished comedy, A Journey to Bath, seems to show in the person of Mrs. Tryfort the most immediate ancestress of Mrs. Malaprop. The familiar story of Richard Brinsley Sheridan's courtship of Elizabeth Linley, the favourite of the Bath concert stage, with its attendant circumstances of elopement, duels, and journeys that ended in lovers meeting, is in itself a dramatic romance.

Early evidence of Sheridan's interest in drama is to be found in his revision, under the title of Jupiter, of a farce, Ixion, written by his Harrow schoolmate, Halhed. A sentence from one of Halhed's letters shows that the idea of recasting the play in the form of a rehearsal, after the fashion set by Villiers in The Rehearsal, was due to Sheridan. Simile and his companions, who interrupt the progress of the rehearsal with questions, evidently foreshadow Puff, Dangle, and Sneer. Jupiter failed to appeal to the managers, but in The Critic Sheridan realized the possibilities of its general framework. The collaboration of Halhed and Sheridan had, however, some tangible result, in the publication of a verse translation of The Love Epistles of Aristanetus (I77I), which managed to achieve a second edition. With the removal of the Sheridan family to Bath, in I770, Richard Sheridan's interest was soon diverted to the actual world of fashionable society. In Clio's Protest 
he rhymed some of the reigning beauties of Bath, and in the form of a humorous epistle, written in the popular fashion of Christopher Anstey's New Bath Guide, he penned some occasional verses for the opening of the new Assembly Rooms. Unconsciously, perhaps, he was roughly sketching scenes which were soon to supply him with a setting for actual drama.

After his marriage, Sheridan found necessity the mother of dramatic invention. Turning instinctively to playwriting for a livelihood, he found in Bath society a natural background for comedy. On I7 January, 1775, The Rivals was produced at Covent Garden Theatre. Various causes combined to make the first performance a failure - excessive length, incompetent acting, especially on the part of Lee, as Sir Lucius O'Trigger, and of Shuter, who was grossly ignorant of his lines as Sir Anthony Absolute, and opposition in the audience, perhaps partly malicious and certainly somewhat resentful of 'so villainous a portrait of an Irish Gentleman'1 as that of Sir Lucius. 'The Rivals, as a Comedy,' remarked The Public Ledger of 18 January, 'requires much castigation and the pruning hand of judgment, before it can ever pass on the Town as even a tolerable Piece.' In deference to the general verdict, the play was withdrawn and vigorously revised. The second ${ }^{2}$ performance, on 28 January, was a marked success.

1 This and subsequent critical excerpts are from contemporary newspapers and magazines, cited in full in the Appendix to the present writer's Major Dramas of Richard Brinsley Sheridan, pp. 313-320.

2 The usual assertion that The Rivals was produced a second time before its withdrawal for revision is fully disproved, Ibid., pp. Ixvi-lxvii. 
Clinch was substituted for Lee in the part of Sir Lucius, and Shuter 'entirely recovered his credit.' The play itself, which had formerly been 'a full hour longer in the representation than any piece on the stage,' was now compressed 'within a reasonable compass,' and Sheridan 'very judiciously removed everything that could give offence in the character of Sir Lucius O'Trigger.' Contemporary evidence as to both the extent and the effectiveness of the revision is abundant and conclusive. Equally successful were the performances of the revised comedy at Bath in March, and at Southampton and Bristol later in the year. Henceforth, The Rivals was firmly entrenched in popular favour.

In the 'Prologue spoken on the tenth night,' Sheridan could now point boldly to the figure of comedy, and challenge moralizing sentimental dramatists with these questions :

Look on her well - does she seem form'd to teach?

Shou'd you expect to hear this lady - preach ?

Must we displace her? And instead advance

The Goddess of the woeful countenance -

The sentimental Muse!

In the play itself, the heroine of sentimental comedy is satirized in the person of Lydia Languish, who is ready to 'die with disappointment' when 'the prettiest distress imaginable' and the prospect of 'one of the most sentimental elopements' seem about to fade into the common light of conventional matrimony. Fond visions of 'so becoming a disguise ! - so amiable a ladder of Ropes ! - Conscious Moon - four 
horses - Scotch parson - with such surprise to Mrs. Malaprop - and such paragraphs in the News-papers' are prosaically shattered by her 'Aunt's consent and approbation.' The 'dear delicious shifts' to gain a moment's interview with her lover are now only a memory. 'How often have I stole forth, in the coldest night in January, and found him in the garden, stuck like a dripping statue ! - There would he kneel to me in the snow, and sneeze and cough so pathetically! he shivering with cold, and I with apprehension ! and while the freezing blast numb'd our joints, how warmly would he press me to pity his flame, and glow with mutual ardour! - Ah, Julia! that was something like being in love!' In one respect, indeed, Lydia differs from her languishing sisters of sentimental comedy, for she prefers a halfpay Ensign to a Captain with a comfortable fortune. 'The tears of sensibility' had been wont to dry with alacrity when virtue found that it need not be content with its own reward. In the scene of Lydia's opening conversation with her maid, Lucy, Sheridan broadens his satire of sentimentality with playful hits at the sentimental novels of the circulating library. Lydia Languish is, in fact, more than a whimsical exaggeration of the heroine of sentimental comedy. She is, as Mrs. Malaprop might say, 'the very pine-apple' of sentimentality.

Yet, like Goldsmith, Sheridan could not at once rid himself wholly of the contagion of the sentimentality which he attacked. Consciously, or not, he allowed the Julia-Faulkland underplot to retain in some measure the conventional phrasing of sentimental 
drama. Though Faulkland is a 'humour' character, in whom jealousy is carried to comic exaggeration, some of his and of Julia's speeches seem rather an unconscious echo of sentimental diction than raillery at its extravagance. Julia's speech which concludes the play may serve for a single illustration: 'While Hope pictures to us a flattering scene of future Bliss, let us deny its pencil those colours which are too bright to be lasting. - When Hearts deserving Happiness would unite their fortunes, Virtue would crown them with an unfading garland of modest, hurtless flowers ; but ill-judging Passion will force the gaudier Rose into the wreath, whose thorn offends them, when its Leaves are dropt!' This sentimental strain no doubt largely explains favourable comments, even in the midst of general strictures upon the first performance of the play, such as the following: "The character of Faulkland is touched with a delicate and masterly hand,' and 'Faulkland, in most respects, a new, and a very good character. ... Julia (considered in the line of elegant and sentimental Comedy) is an honour to the drama.' 1 The Morning Chronicle of 18 January goes so far as to assert that 'the characters of Falkland and Julia are even beyond the pitch of sentimental comedy, and may be not improperly stiled metaphysical,' and to compare 'the romantic vein of Lydia Languish' with that of Steele's Biddy Tipkin, to the disadvantage of Sheridan. Such discordant criticisms have at least this in common, that they recognize in the underplot of The Rivals

1 Communication signed 'Impartialist,' in The Morning Post, 20 January, 1775 . 
some suggestion of the sentimental comedy against which Sheridan was, in the main, in revolt.

The concessions to sentimentality which, in Sheridan's day, furthered the success of The Rivals, have now largely lost their appeal. Mr. Joseph Jefferson's acting version entirely omitted the part of Julia, retaining Faulkland only for the sake of his effective scene with Bob Acres. ${ }^{1}$ The ease with which Mr. Jefferson excised most of the underplot suggests, in fact, some structural weakness in the play. Yet neither occasional traces of sentimental diction nor minor flaws in dramatic structure have seriously endangered the enduring vitality of The Rivals. The main action is developed through a constant succession of effective stage situations. The quarrel scene between Sir Anthony Absolute and his son, the scenes of Mrs. Malaprop, and the duel would, in themselves, command interest, but their effectiveness is enhanced by their position as vital links in the chain of dramatic action. Like Goldsmith, Sheridan prefers 'expectation' to 'surprise' as a dramatic motive. At the outset Fag explains that Captain Absolute and Ensign Beverley 'are one and the same person.' In the postulates of plot Sheridan seems more natural than Goldsmith. His use of 'mistaken identity' and 'cross purposes' results in a comedy of errors more plausible than Goldsmith's mistakes of a night.

If there are farcical suggestions in The Rivals they arise rather from character than from plot. The very names of the dramatis personce suggest their

1 For a full account of Mr. Jefferson's version, see the present writer's Major Dramas of Richard Brinsley Sheridan, pp.323-325. 
kinship with 'humour comedy.' The accentuation of individual traits of character is, however, not confined to names like Languish, Malaprop, O'Trigger, Absolute, Acres, Fag. Faulkland's 'humour' is unreasonable jealousy, as clearly as that of Sir Lucius O'Trigger is love of fighting. Furthermore, The Rivals introduces two highly developed artificial humours in the 'oath referential, or sentimental swearing' of Bob Acres, and in Mrs. Malaprop's 'nice derangement of epitaphs.' Like Dickens, Sheridan often outlines character with broad strokes that suggest caricature. Yet it should be remembered that it is easier to justify exaggeration in the dramatist than in the novelist, and that Shakespeare bestowed upon Mrs. Quickly abnormal perversity in the use of her 'oracular' tongue. Whatever aspersions may be cast upon her 'parts of speech,' Mrs. Malaprop remains, among a host of dramatic predecessors and imitators, the unrivalled 'queen of the dictionary.' Doubtless Sheridan lacks subtlety in the analysis of character, but he has an exceptional sense of theatrical effectiveness. The courage of Bob Acres dwindles to the actual vanishing point when he feels his valour 'oozing out as it were at the palms of his hands,' but the very exaggeration of cowardice enhances the acting possibilities of the duel scene. The 'passion' of Sir Anthony Absolute mounts to sheer hyperbole, but heightens the dramatic climax of the quarrel scene with his son. If there are suggestions of farcical exaggeration and unrestraint in Sheridan's delineation of character, he has, at least, extraordinary mastery of effective dramatic art. 
In dialogue, as in character portrayal, Sheridan has the same brilliant artificiality. He sacrifices naturalness on the altar of wit. Unlike honest Diggory, Fag and David vie in wit with their masters. Pope's question - 'Tell me if Congreve's fools are fools indeed ?' - might be applied to Sheridan. Lucy's cleverness outwits Mrs. Malaprop, and her arch coquetry captivates Sir Lucius. Even the sentimental excrescences of the underplot do not long interrupt the brilliant vivacity of Sheridan's dialogue. The Rivals is the initial work of a dramatist of twentythree. If it fails to hold the mirror up to nature, it has, none the less, splendid audacity and fertility of dramatic invention and wit. It remains a triumph of artificial comedy.

On 2 May, I775, Sheridan's brief farce, St. Patrick's Day, or The Scheming Lieutenant, was produced at Covent Garden. It was written for the benefit of Clinch, the actor whose substitution for Lee in the part of Sir Lucius O'Trigger had contributed much toward the ultimate success of The Rivals. The farce seems somewhat reminiscent of Molière, with whose work Sheridan may have gained acquaintance through English translations. The dialogue contains some sprightly passages that are characteristic of the author, but, for the most part, Sheridan seems to have written it with his left hand.

Far more significant was the production, on 21 November of the same year, of The Duenna. For almost half a century no opera had rivalled the initial success of The Beggar's Opera. The Duenna surpassed the run of Gay's ballad opera by achieving seventy- 
five performances before the close of the season. Much of its success was due to the music which was largely composed by Sheridan's father-in-law, Linley. Sheridan also availed himself of the work of other musicians like Jackson and Harrington - a method of 'compiling' opera of which Linley openly expressed his disapproval. Despite his lack of technical musical skill, Sheridan deserves no small share of credit in the lyric success of the opera. His verses are usually well adapted for singing, and many of his lyrics, such as 'Oh, the days when I was young,' and 'Had I a heart for falsehood framed,' long remained popular. Interspersed with pretty, if somewhat conventional, love songs and serenades are some snatches of rather rollicking and whimsical humour, as in some of the verses given to Don Jerome and Isaac, and in the opening trio which seems almost a parody of the heroics of grand opera.

Though it is unfair to judge the libretto of an opera by the standards of ordinary drama, The Duenna is not without dramatic merits. The plot has a distinct basis of action and progresses to an effective solution. Some of the scenes, like those of Isaac's wooing of the Duenna, and his report to Louisa's father of his extraordinary success in courtship, are well conceived. Moore declared that the 'intrigue' was founded upon an incident in Wycherley's Country Wife, and Sheridan, despite his assertion that he had never read a line of Wycherley, could hardly have been ignorant of Garrick's popular adaptation of the play as The Country Girl. Yet, in general, his use of disguise, mistaken identity, 
and cross purposes, betrays chiefly his general familiarity with stage traditions. The characters of The Duenna seem unfinished in comparison with those of The Rivals. Don Jerome, the stern and then relenting father, is but a shadow of Sir Anthony, and the jealous Ferdinand of Faulkland. Louisa and Clara are not clearly differentiated, but Isaac is a more finished portrait. The dialogue, though without sustained brilliancy, is at times enlivened with characteristic flashes of Sheridan's wit. In comparison with the comedies, The Duenna seems mediocre, but its libretto has a coherence of plot and a general dramatic consistency in lyric and dialogue unusual in light opera. As a rough illustration, it may be said to bear somewhat the same relation to most of the operas of its day as that of the Gilbert and Sullivan operas to the general run of contemporary musical comedies.

In 1776 Sheridan succeeded David Garrick as manager of Drury Lane Theatre. Not until 24 February, 1777, however, were general expectations of a new play from the playwright-manager even partially realized in his adaptation of Vanbrugh's Relapse as $A$ Trip to Scarborough. The attempt

to draw some slender cov'ring o'er That graceless wit which was too bare before

in a Restoration comedy that Jeremy Collier had selected for specific attack was hazardous. Yet, if Sheridan unfortunately cut away some sound tissue of comedy, together with its worst impurities, many of his excisions are effective. In various mechanical 
details, such as the condensation of the fifth act and the substitution of eighteenth-century 'local colour' for that of the Restoration period, his alterations may have proved effective, but he sacrificed something of the spirit and vivacity of the original. In The Critic he put into the mouth of Dangle, a playful hit that seems directed at his own effort to expurgate Restoration comedy, - 'Now, egad, I think the worst alteration is in the nicety of the audience ! - No double entendre, no smart innuendo admitted; even Vanbrugh and Congreve obliged to undergo a bungling reformation !' Sheridan's adaptations from Kotzebue, The Stranger (I 798) and Pizarro (I 799), belong to a later period that exceeds the limits of the present discussion, but, like $A$ Trip to Scarborough, they give proofs of his practical sense of theatrical effectiveness without enhancing his reputation as an original dramatist.

On 8 May, I777, Sheridan triumphantly met the popular demand for original comedy with The School for Scandal. During the brief balance of the season it had a score of performances, and it was produced sixty-five times during the next year. It was a triumph of acting as well as of dramatic art. Even Horace Walpole, ${ }^{1}$ in a letter of July ${ }_{13}$, was compelled to unusual superlatives : 'To my great astonishment there were more parts performed admirably in The School for Scandal than I almost ever saw in any play. ... It seemed a marvellous resurrection of the stage. Indeed, the play had as much merits as the actors. I have seen no comedy that comes near

${ }^{1}$ Letters of Horace Walpole, Toynbee edition, X, 82. 
it since The Provoked Busband.' Two seasons later the treasurer of Drury Lane recorded the fact that the 'School for Scandal damped the new pieces.'

The dramatic construction of Sheridan's comedy at once attracted favourable comment. On the day following its first production, the critic of The Public Advertiser (9 May) declared: "The Situations are so powerfully conceived, that little is left for the Performers to do, in Order to produce what is called Stage Effect; and the Circumstance of the Screen and Closet in the fourth Effect, produced a Burst of Applause beyond any Thing ever heard perhaps in a Theatre.' To the same effect ran the review in The London Chronicle, 8-10 May: 'The fable is well conducted and the incidents are managed with great judgment. There hardly ever was a better dramatic situation than that which occurs in the fourth act, where Sir Peter discovers Lady Teazle in Joseph Surface's study.' The test of time has fully confirmed the unqualified praise thus bestowed on the 'screen scene.' It remains not merely the most notable scene in the English comedy of manners, but one of the masterpieces of English dramatic art. Only less noteworthy are the 'picture scene' in the house of Charles Surface, the scandal scenes, and the conversations between Sir Peter and Lady Teazle. Though more dependent upon the wit of the dialogue, they brilliantly illustrate Sheridan's dramatic skill. Objection has sometimes been made to the scandal scenes on the ground that the dialogue does not always directly advance the action. Yet, apart from their brilliancy, they may find justification in furnishing 
the necessary background and environment for Lady Teazle. The not infrequent modern rearrangement which groups in the opening act several of the scattered scandal scenes may be a theatrical convenience, but it is questionable whether it does not somewhat retard the exposition of plot and impair the continuity of background suggested in the original version.

Like The Rivals, The School for Scandal seems to have been a natural outgrowth of Sheridan's experience of fashionable society at Bath. The first rough sketch was headed, THE SLANDERERS. $-A$ Pump Room Scene. The details of its evolution into finished comedy, fully supplied in Moore's Life of Sheridan, give ample evidence of Sheridan's painstaking. Two plots were gradually welded together one dealing with the scandal group, the other with a young country wife involved in matrimonial difficulties with an old husband. The process of revision was elaborate, not merely in the consolidation of plots, and in the refinement of dialogue, but even in the details of nomenclature of the characters. Just as the scene itself was shifted ultimately from the miniature world of fashion at Bath to the larger world of London society, Solomon Teazle and his wife were not suffered to remain bourgeois, but were invested with the dignity of rank. The youthful hero had half-a-dozen tentative names before he became Charles Surface. Even the minor characters were not overlooked - Spunge became Trip, and Spatter finally became Snake.

The history of Sheridan's constant revisions of 
his text effectually proves that The School for Scandal was not the product of genius that never blotted a line. Careless and indifferent in many ways Sheridan was undeniably. He could not be brought to superintend the preparation of the text of The School for Scandal for publication. Yet the traditional anecdotes that have encouraged the popular impression that he struck off his pieces at white heat under forced draught are misleading. Much of the dialogue of The School for Scandal shows careful construction. The brilliant passages at arms between Lady Teazle and Sir Peter furnish a number of climaxes attained only by a clever manipulation of phrase throughout considerable preliminary dialogue. Such, for example, is the passage which culminates in Lady Teazle's 'For my part, I should think you would like to have your wife thought a woman of Taste,' and Sir Peter's unhappy rejoinder, 'Aye - there again - Taste! Zounds! Madam, you had no Taste when you married me !' Incessant brilliancy of phrase is, indeed, at once the strength and the weakness of Sheridan's dialogue. Trip is invested with his master's wit as readily as with his master's wardrobe. There are no dullards among the scandal-mongers. Relieved of the modern 'gags' which have been imposed upon him, even Moses has a pretty wit of his own that raises money-lending to a fine art. Rowley, the honest steward, quotes Shakespeare, and, after the exposure of Joseph Surface, vies with Sir Oliver in taunting Sir Peter, after the fashion of Gratiano, with his own phrases. Perhaps only the flitting figure of Maria seems out of place in this brilliant setting. 
The School for Scandal marks the height of the development of the comedy of manners. It is the artificial comedy of the Restoration purged of indecency, but undiminished in lustre. The ceaseless sparkle of its dialogue inevitably recalls Congreve. Investigation of the sources of its plot has resulted in establishing its general kinship. with the comedies of Congreve and Wycherley, and, especially in the case of the scandal scenes, some specific instances of direct indebtedness. Even the Lady Teazle-Sir Peter plot, which has perhaps been somewhat slighted in the zealous pursuit of the ancestry of the Surface brothers, is anticipated in the situation of $\mathrm{Mr}$. and Mrs. Pinchwife in Wycherley's Country Wife. Lady Teazle and Mrs. Pinchwife are both moths attracted by the flame of temptation, but Lady Teazle is not seared by the fire that ruthlessly consumes her Restoration prototype. Like the comic dramatists of the Restoration, Sheridan was indebted to Molière, but, unlike them, he touched the comedy of intrigue with Gallic esprit undefiled by impurity. One of the phrases which Sheridan applied to Mrs. Crewe in the verses of The Portrait which he addressed to her in connection with The School for Scandal may well be taken to characterize the spirit of his own comedy - 'Not stiff with prudence nor uncouthly wild.'

The School for Scandal is not merely the redemption of the artificial comedy of the Restoration from its grossness, but the triumph of the comedy of manners over sentimental comedy. Nevertheless, like The Rivals, it shows some lapses into the diction of senti- 
mental drama. In his last speech, Charles Surface turns to Maria with these words: 'But here-shall be my Monitor - my gentle Guide - ah! can I leave. the Virtuous path those Eyes illumine?' As in the final words of Julia in The Rivals, Sheridan makes a. somewhat lame and impotent conclusion. Yet the real spirit of his comedies is not to be sought in chance scene-tags. / When, in the words of the Prologue, 'Again our young Don Quixote takes the road,' and 'seeks his hydra, Scandal, in his den,' Sheridan is armed in the true spirit of comedy to attack the faults and follies of society.) Furthermore, the sententious moralizing of 'weeping sentimental comedy' is held up to ridicule in the person of the hypocrite, Joseph Surface. 'Joseph is indeed a model for the young men of the Age - He is a man of Sentiment - and acts up to the Sentiments he professes.' $\mathrm{He}$ is so habituated to the false gallop of sentiment that he gives sentiment free rein even when it is unnecessary. 'O Lud,' interrupts Lady Sneerwell, 'you are going to be moral, and forget that you are among Friends.' The exposure of his hypocrisy is anticipated by $\mathrm{Sir}$ Peter's iteration of the phrase, ' $\mathrm{He}$ is a man of Sentiment - Well ! there is nothing in the world so noble as a man of Sentiment,' and is emphasized by its taunting reëcho when Sir Peter is confronted with the evidence of his mistaken judgment. And when Joseph Surface finally disappears in the last act, he is still 'moral to the last drop.' With him, moralizing sentiment retires baffled and discountenanced.

Sheridan's attacks on sentimental drama culminate 
in The Critic, or A Tragedy Rehearsed. Produced at Drury Lane, 30 October, I779, as an afterpiece to Hamlet, it 'fully gratified,' according to The Public Advertiser of I November, 'the Expectation of the Public, which had presaged every Excellence from the Pen of their favourite Author.' This review of the first performance further remarks: 'The two leading Objects of this witty Stage Satire appear to be these First, to expose the mock Comments of News-paper and other minor Critics; and next, to ridicule the false Taste and brilliant Follies of modern dramatic Composition.' Sheridan's satire sweeps freely over the whole range of absurdities in drama and theatrical production. The very breadth and universality of its ridicule has given it enduring vitality. Burlesque is essentially ephemeral. The success of parody is dependent upon familiarity with the objects of its attack. Many of Sheridan's specific hits that were palpable to the audience of his day pass to-day unheeded. Yet, in adapting to his own purpose the general framework of The Rehearsal, he was less dependent upon local allusion and definite parody than were Buckingham and his associates

In those gay days of wickedness and wit, When Villiers criticiz'd what Dryden writ. ${ }^{1}$

Arber's reprint of The Rehearsal, with the key to the passages of contemporary drama burlesqued, is conclusive testimony to the extent and elaborateness of specific parody. But The Critic, despite some passages that seem definitely directed against the trage-

1 Richard Fitzpatrick's Prologue to The Critic. 
dies of John Home, ${ }^{1}$ bends its chief energies to exposing general absurdities in the drama. To this effect runs the review in The Public Advertiser: 'The tedious and unartificial Commencements of modern Tragedies, the inflated Diction, the figurative Tautology, the Feu de Theatre of Embraces and Groans, Vows and Prayers, florid Pathos, whining Heroism, and, above all, the Trick of Stage Situation, are ridiculed with a Burlesque which perhaps may be thought rather too refined for the Multitude, but certainly is perfect in its Stile' The fear that The Critic might prove caviare to the general was not realized. The perfection of its style and the breadth of its satire have not been obscured even by some admixture of elements as ephemeral as local allusion and parody.

From the outset, The Critic satirizes sentimental drama. Especially significant is the following passage in the opening scene:

Dangle (reading). Bursts into tears and exit.-What, is this a tragedy!

Sneer. No, that's a genteel comedy, not a translation - only taken from the French; it is written in a stile which they have lately tried to run down; the true sentimental, and nothing ridiculous in it from the beginning to the end.

Mrs. Dangle. Well, if they had kept to that, I should not have been such an enemy to the stage; there was some edification to be got from those pieces, Mr. Sneer !

Sneer. I am quite of your opinion, Mrs. Dangle; the theatre, in proper hands, might certainly be made the school of morality; but now, I am sorry to say it, people seem to go there principally for their entertainment !

1 The Monthly Review, October, 1781, in reviewing the first printed edition of The Critic objects that its author has 'levelled some of his severest traits against the very best modern tragedy in our language, we mean the tragedy of Douglas l' 
Though Sheridan is primarily attacking sentimental drama in general, he seems to direct a particular thrust at Hugh Kelly. Sneer's words are but a mocking echo of the creed declared by Kelly, in the last act of False Delicacy - 'The stage should be a school of morality.' Among the sentimental dramatists, however, Sheridan found an even more vulnerable target in Sir Richard Cumberland. In Sir Fretful Plagiary he drew to the life the portrait of the playwright whom Garrick termed a 'man without a skin.' The Memoirs of Richard Cumberland written by himself is an unconscious revelation of the inordinate jealousy, selfesteem, and supersensitiveness of its author. Even Watkins, Sheridan's unsympathetic biographer, who volubly defended 'the moral excellence of the dramas of Cumberland,' reluctantly confessed ${ }^{1}$ that 'the character of Sir Fretful Plagiary must be admitted to have exhibited a striking sketch, in many respects, of a dramatic writer, whose nervous sensibility often made him ridiculous.' Yet, like a genuine artist, Sheridan not merely reproduced an individual likeness, but created a masterpiece of portraiture. $\mathrm{Had}$ Sir Fretful been merely a personal caricature, he could hardly have outlived Cumberland.

Though The Critic was written only as an afterpiece, it holds its own, in some respects, with Sheridan's comedies. It is the triumph of sheer wit over the usual transitoriness of burlesque. In brilliancy of dialogue it vies with The School for Scandal. Throughout the first act, save possibly in the brief interruption of the Italians and their interpreter, action is wholly 
subordinated to conversation. Even the bustle of the Italian episode is chiefly effective as a provocative to Dangle's admirable retorts, while Puff's description of the various sorts of 'puffing' is a verbal tour de force. In the two acts devoted to the rehearsal of Puff's tragedy, the action of the burlesque yields constantly to Puff's illuminating explanations to his interlocutors. Many even of the chance phases of The Critic have become proverbial, such as Sneer's 'No scandal about Queen Elizabeth, I hope,' and Puff's 'Where they do agree on the stage, their unanimity is wonderful!' In The Critical Review, November, I781, a reviewer who did not hesitate to condemn the 'wantoness of wit' in The Critic, declared: 'There is, indeed, more true wit and humour crouded into this little performance, than has, perhaps, appeared since the days of Wycherley and Congreve.' Age has somewhat withered the local hits in The Critic, but custom has not staled its infinite wit and felicity of phrase.

The extraordinary brilliancy of The Critic has often raised questions as to its genuine originality. The general framework, already tentatively tested in Sheridan's early burlesque, Jupiter, is taken from The Rehearsal. Bayes and his companions, Johnson and Smith, are the rough models for Puff and his associates, Sneer and Dangle. A few verbal parallels in The Rehearsal and in various farces of Fielding and Foote, and a passage in Churchill's Rosciad show that Sheridan did not hesitate to appropriate to his own purposes some specific hints from earlier writers. It is unnecessary, however, to defend him by pervert- 
ing Sir Fretful's remark that 'a dexterous plagiarist may do anything.' If the 'pruning-knife,' or in Puff's emendation the 'axe,' of criticism were applied to all the foreign graftings on the native stock of The Critic its vitality would not be endangered.

The Critic marks practically the conclusion of Sheridan's original dramatic work. At twenty-eight he was not merely arbiter of Drury Lane, but the foremost of living English dramatists. Like Congreve who, at thirty, practically bade farewell to comedy, Sheridan early abandoned the career of active playwright. During the long years of his public service his interest was in politics. His treasure lay in Drury Lane, but his heart was in Parliament. His occasional later efforts as a playwright are adaptations rather than original dramatic works. Pizarro (I 799), based on Kotzebue's Spaniards in Peru, and embellished with touches borrowed from his own oratory, was a financial, not a literary, triumph. In diction and melodramatic machinery, it is open to some of the very attacks directed at Puff's tragedy. The lapse of twenty years since The Critic had brought no deeper maturity of dramatic conception. Sheridan's powers developed early. A dramatic artist, not a deep interpreter of life, he brilliantly touched the surface without sounding the depths. There are more things in heaven and earth than are dreamt of in his philosophy. He was, indeed, no dreamer. His eyes sought the immediate foreground, not the far horizon. In the wood outside of Athens he might have recognized Nick Bottom and his fellows, while Oberon and Titania flitted past unheeded. Sheridan's world, in 
reality, was_Bath-and London. Even Lydia Languish, who sought a sentimental elopement to shock society, would have been a sorry exile in the Forest of Arden. Wit rather than humour, brilliancy. rather than depth, satire rather than sympathy, art rather than nature, are the characteristics of Sheridan's comedies. Yet Beaumarchais is not to be misprized because he is not Molière. Unable to follow Shakespeare through the depths of the 'comédie humaine,' Sheridan wisely chose, under the leadership of the comic dramatists of the Restoration, to pursue the easier path of the comedy of manners.

Judged merely by the test of continued stage popularity, Sheridan stands to-day in English drama second only to Shakespeare. The professional verdict of the modern stage is well expressed in the words of Sir Henry Irving: 'Sheridan brought the comedy of manners to the highest perfection, and The School for Scandal remains to this day the most popular comedy in the English language. Some of the characters both in this play and in The Rivals have become so closely associated with our current speech that we may fairly regard them as imperishable. No farce of our time has so excellent a chance of immortal'ity as The Critic.' 1 The history of the development of English drama since the reopening of the theatres in 1660 reaches a significant climax in Sheridan. He is at once the heir to the best traditions of Restoration comedy and the most notable English dramatist of the eighteenth century.

1 W. Fraser Rae, Life of Sheridan, II, 322. 



\section{BIBLIOGRAPHICAL NOTES}

TrEse Bibliographical Notes aim (I) to indicate the chief texts, documents, critical editions, and other works cited in this volume, and (2) to suggest some useful references for the general student of English drama. An elaborate bibliography for the whole period of English drama here considered would far exceed the limits of this book. Fortunately, the extensive bibliographies in various volumes of The Cambridge History of English Literature meet, in large part, the demands even of special investigation. Their publication, since the inception of the present work, renders it unnecessary to reproduce here lists of the individual dramatic works of the different playwrights, or of the multitude of biographical and critical works there mentioned. In the case of eighteenth-century English drama, a word of personal explanation seems unavoidable. My bibliography to chap. IV of vol. X of The Cambridge History of English Literature supplies, in addition to the sections dealing with individual playwrights, a series of chronological lists of eighteenth-century collections of plays, of prologues and epilogues, and of theatrical histories, dictionaries, and similar works bearing on the period, together with other general material. 'A Bibliographical Note' (pp. cxi-cxvii) to The Major Dramas of Richard Brinsley Sheridan contains additional data. Hence it has been deemed advisable to omit here much material already presented elsewhere, and to consider the present commentary as primarily suggestive and explanatory. Yet it is hoped that these notes, together with the footnotes in the main body of the book, will sufficiently indicate specific texts quoted and definite sources of historical and critical material. Throughout this volume, quotations, references, and bibliographical descriptions are based directly on the actual texts cited. The more detailed 'Notes to Separate Chapters' are here preceded by some suggestions as to general reference 
works. For the ordinary reader it seems sufficient to show the character and utility of a few representative works. Such general hints, needless to say, are not for the specialist, much of whose material must often evade the confines of even the most generous bibliography. The present Notes will fulfil their aim if they give reasonable guidance for ordinary purposes of reference, and indicate, however imperfectly, the obligations here gratefully acknowledged to many works which have proved of great assistance.

\section{GENERAL REFERENCE WORKS}

Bracketed names or titles in heavy capitals indicate abbreviations for convenience of reference: e.g. [GENEST]; [BIOG. DRAM.]. In general, the place of publication, if not otherwise indicated, is London.

The most important statistical record of English drama covering the whole period of this volume is

Some Account of the English Stage, from the Restoration in I660 to 1830 [by John Genest]. Io vols. Bath, 1832. [GENEST.] This absolutely indispensable reference work is essentially a great theatrical diary, recording a very large proportion of the dramatic productions at the chief London theatres from 1660 to 1830 , supplying many synopses of plots, casts of characters, records of important actors, and a fund of general theatrical information, but attempting no comprehensive survey of the development of English drama. Its incidental critical comments are much less significant than its usually reliable statistics.

Perhaps the most useful theatrical dictionary covering the whole period of this volume is

Biographia Dramatica; or, A Companion to the Playhouse. ... Originally compiled, to the year 1764 , by David Erskine Baker. Continued thence to $\mathbf{1 7 8 2}$, by Isaac Reed, F. A. S. And brought down to the End of November 1811 ... by Stephen Jones. 3 vols. [Vol. I in two parts, usually bound separately.] 1812. [BIOG. DRAM.] The chief value of this work lies in its 'alphabetical account and chronological lists' of English dramatists and their works. The two parts of vol. I 
deal with authors; vols. II and III, with separate dramatic works. Dates of plays are those of publication, and are less reliable than Genest's dates of first productions. The chronological lists of works under individual author-headings are useful, but the biographical material is usually inadequate and of ten unreliable.

An excellent general reference work for theatrical documents is

A Bibliographical Account of English Theatrical Literature from the earliest times to the present day, by Robert W. Lowe. 1888. [LOWE.] This record, in general, excludes plays, unless they include historical or critical matter, and accordingly supplements rather than duplicates Biog. Dram. Full and accurate citations of many title-pages and frequent crossreferences make this work both reliable and convenient for constant use.

An authoritative detailed critical study of Restoration and Queen Anne drama is included in

A History of English Dramatic Literature to the death of Queen Anne, by Adolphus William Ward. New and revised edition. 3 vols. London and New York, 1899. [WARD.] For discussion of English drama from the closing of the theatres in 1642 to the death of Queen Anne in 1714, see especially vol. III, chap. IX. An ample index increases the usefulness of this scholarly standard work of English dramatic history.

A very considerable recent critical review of Restoration drama is included in

The Cambridge History of English Literature, vol. VIII (1912), chapters V, VI, and VII, by F. E. Schelling, Charles Whibley, and A. T. Bartholomew respectively. Cambridge. [CAMB. HIST.] These important chapters have valuable bibliographies. References in the present work are to the original edition, not to the New York reprint which often differs in pagination.

An excellent and comprehensive critical account of Restoration and eighteenth-century tragedy is accessible in

Tragedy, by Ashley H. Thorndike. [In The Types of English Literature, edited by William Allan Neilson.] Boston and New York, 1908. [THORNDIKE.] Chapter VIII deals with 'The 
Restoration'; chapter IX with 'The Eighteenth Century.' Each chapter ends with a suggestive 'Note on Bibliography.'

A convenient general history of the London stage is

History of the London Stage and its Famous Players (15761903), by H. Barton Baker. London and New York, I904. [H. B. BAKER.] This work appeared originally as The London Stage: Its History and Traditions from 1576 to 1888.2 vols. I889. Though not free from inaccuracies in quotations and other details, it furnishes useful material as to the London theatres.

A more extended account of the English stage during the Restoration and eighteenth century is

"Their Majesties' Servants." Annals of the English Stage from Thomas Betterton to Edmund Kean, by Dr. Doran, F. S. A. Edited and revised by Robert W. Lowe. 3 vols. 1888. [DORAN, Annals.] This work appeared originally in two volumes, in 1864. Mr. Lowe's corrections and annotations notably increase the value of this useful, if rather discursive, popular history.

The most trustworthy general reference work for biographies of dramatists and actors is

Dictionary of National Biography, edited by Leslie Stephen and Sidney Lee. Revised edition. 22 vols. London and New York, I908-1909. [DICT. NAT. BIOG.] Some of the lesser playwrights and actors omitted in this work are included in Biog. Dram., and in some other cases Biog. Dram. furnishes fuller bibliographical information as to printed editions of plays, but the Dict. Nat. Biog. is the indispensable standard authority.

The works mentioned above, it should be emphasized, are simply representative of important general reference authorities dealing definitely with some of the broader aspects of English drama and theatrical history discussed in this volume. Many of the works cited in the 'Notes to Separate Chapters' are also of considerable scope. Thus, for random illustration, Colley Cibber's A pology is actually ' an Historical View of the Stage during his Own Time,' and, especially in R. W. Lowe's fully annotated edition, is a valuable reference work for a considerable period of English theatrical history. General his- 
tories and manuals of English literature have not been listed, but such volumes as those in the admirable series of $\boldsymbol{H}$ andbooks of English Literature, edited by Professor Hales, are useful.

For fuller bibliographical notes on 'Theatrical Histories, Dictionaries, and General Records,' reference may be made to the section (VI) thus entitled in the bibliography to chap. IV, vol. X, of The Cambridge History of English Literature. Though that list more definitely concerns eighteenth-century drama, a large proportion of the works there cited cover also the Restoration period. Two contemporary theatrical records concerning the Restoration stage which did not fall within the limits of that bibliography seem sufficiently important to be listed here.

Historia Histrionica: An Historical Account of the EnglishStage, Shewing The ancient Use, Improvement, and Perfection, of Dramatick Representations, in this Nation. In a Dialogue, of Plays and Players. [By James Wright.] 1699. Quotations in the present work are from the British Museum copy of the original edition. Historia Histrionica is accessible in various modern reprints: No. XXX in E. W. Ashbee's Occasional FacSimile Reprints, 1872 ; in vol. XV (1876) of W. Carew Hazlitt's edition of Dodsley's $A$ Select Collection of Old English Plays; in vol. I (1889) of R. W. Lowe's edition of An Apology for the Life of Mr. Colley Cibber.

Roscius Anglicanus, or, An Historical Review of the Stage ... from 1660 to 1706 . [By John Downes, prompter at the theatre in Lincoln's Inn Fields.] 1708. Quotations are from the Bodleian Library copy of the original edition. Roscius Anglicanus was reprinted, 'With Additions, by the late Mr. Thomas Davies,' in 1789. An excellent recent edition is Roscius Anglicamus. . . A Fac-Simile Reprint of the Rare Original of 1708. With an historical preface by Joseph Knight. 1886. 


\section{NOTES TO SEPARATE CHAPTERS}

Bracketed names or titles in heavy capitals indicate abbreviations for convenience of reference. Asterisks indicate specific texts from which quotations have been made.

\section{CHAPTER I}

Throughout this volume references to Pepys are based on

* The Diary of Samuel Pepys . . . edited with additions by Henry B. Wheatley. London and Cambridge, vols. I-VIII, 1893-1896; vol. IX, Index, I899; 'Supplementary Volume' ('Pepysiana'), 1899. [WHEATLEY edition.]

Anthony Hamilton's Mémoires de la Vie du Comte de Grammont, Cologne, I713, appeared in an English translation by Boyer, in I7 I4. Among numerous recent English editions of the Memoirs is

* Memoirs of Count Grammont, by Count Anthony Hamilton, edited by Gordon Goodwin. 2 vols. I903. [GOODWIN edition.]

Charles Lamb's essay On the Artificial Comedy of the Last Century appeared originally in The London Magazine, April, 1822, as one of a series of articles on The Old Actors, later rearranged in the Essays of Elia. Quotations in the text follow * The Works of Charles and Mary Lamb, edited by E. V. Lucas, vol. II (1903), pp. I4I-I47.

Macaulay's essay on the Comic Dramatists of the Restoration appeared originally in The Edinburgh Review, January, I84I, as a review of Leigh Hunt's edition of The Dramatic Works of Wycherley, Congreve, Vanbrugh, and Farquhar (1840). Quotations in the text follow the Albany edition of The Works of Lord Macaulay, vol. III (1898), 'Leigh Hunt,' pp. 335-393. [For quotations see especially pp. 344-346.] 


\section{CHAPTER II}

The three ordinances of the Long Parliament against the stage are accessible in

* The English Drama and Stage under the Tudor and Stuart Princes, 1543-1664, illustrated by a series of documents, treatises and poems. [Edited by W. C. Hazlitt.] Printed for the Roxburghe Library. 1869. [HAZLITT, English Drama.]

* The Actors Remonstrance, or Complaint: for the silencing of their profession, and banishment from their severall Playhouses. 1643. [No. IV in E. W. Ashbee's Occasional FacSimile Reprints, 1869.]

The Actors Remonstrance is also reprinted in Hazlitt, English Drama, pp. 259-265.

The drolls should be investigated in Kirkman's collections, here listed from the Bodleian Library copies:

(r) The Wits, or, Sport upon Sport. In Select Pieces of Drollery, Digested into Scenes by way of Dialogue. Together with Variety of Humours of several Nations, fitted for the pleasure and content of all Persons, either in Court, City, Countrey, or Camp. The like never before Published. Part I. 1662.

[Stationer's Address to the Readers signed ' $H$. Marsh.'] This collection (pp. 186) includes 27 'Droll-Humours' with 'A Catalogue of the several Droll-Humours, from what Plays collected, and in what page to be found in this Book.'

(2) The Wits; or, Sport upon Sport. In Selected Pieces of Drollery . . . 1672. [Address 'To the Readers' signed ' Francis Kirkman.'] This collection contains ro pieces, occupying 80 pages, followed, in the Bodleian copy, by a Preface signed 'Fra. Kirkman,' and a reprint (pp. 186) of the 27 Droll-Humours of the r662 edition.

(3) The Wits; or, Sport upon Sport. 1673. [Full title quoted in tert of chapter II.] This collection contains Kirkman's Preface and the ro pieces (here occupying 56 pages) printed in the 1672 edition.

D'A venant.

Quotations from D'Avenant's plays are taken from the Bodleian Library copies of the original editions. The Drama- 
tists of the Restoration Series includes the following critical edition :

The Dramatic Works of Sir William D'Avenant, with prefatory memoir and notes [by James Maidment and W. H. Logan]. 5 vols. Edinburgh and London. 1872-1874.

A recent edition of The Siege of Rhodes, with an excellent introduction and bibliography dealing with D'Avenant's dramatic work, is

Love and Honour and The Siege of Rhodes, by Sir William D'Avenant, edited by James W. Tupper (Belles-Lettres Series), Boston, U. S. A., and London. 1909.

\section{CHAPTER III}

The text of the royal patent of 21 August, r660, is accessible in Edmond Malone's * Historical Account,of the Rise and Progress of the English Stage in his edition of The Plays and Poems of William Shakspeare, I790, vol. I, part II, pp. 244-246. Here also may be found (pp. 239-247) the documents in the controversy between Sir Henry Herbert and the patentees.

For D'Avenant, see Notes to Chapter II. Thomas Killigrew's Comedies and Tragedies [and tragi-comedies] appear in the folio edition of 1664 .

The * Dramatists of the Restoration Series, edited by James Maidment and W. H. Logan, includes the dramatic works of both John Tatham, Edinburgh and London, r879; and John Wilson, Edinburgh and London, 1874 .

Abraham Cowley's plays are reprinted in

* Abraham Cowley, Essays, Plays and Sundry Verses, the text edited by A. R. Waller. Cambridge, rgo6. (In Cambridge English Classics.)

Richard Flecknoe's A Short Discourse of the English Stage is appended to Love's Kingdom. A Pastoral Trage-Comedy, r664. Quotations are from the Bodleian Library copy. Flecknoe's Discourse was reprinted, in 1869, in W. C. Hazlitt's English Drama and Stage, pp. 275-28r.

For discussion of Continental influences upon early Restoration drama and opera in England, see Ward, III, 30I-324, and 
Schelling, chap. V, in vol. VIII of The Cambridge History of English Literalure. Professor Schelling's survey of Spanish influences is especially suggestive, and is supplemented, in his bibliography, with a special section, 'Spanish Influences on English Drama.' For general references to French drama, C. H. Conrad Wright's A History of French Literature (New York and London, 1912) will be found valuable.

\section{CHAPTER IV}

Quotations from Dryden's plays are based on the text of

* The Works of John Dryden, illustrated with notes, histurical, critical, and explanatory, and a life of the author, by Sir Walter Scott, Bart. Revised and corrected by George Saintsbury. 18 vols. Edinburgh [vols. XV-XVIII, London], 18821893. [SCOTT-SAINTSBURY edition.]

Quotations from Dryden's essays are based on the text of

* Essays of John Dryden, selected and edited by W. P. Ker. 2 vols. Oxford, 1900. [KER.] These are standard editions.

For critical biographies, see especially Dryden, by G. Saintsbury (English Men of Letters Series), r88I, and Dryden (chap. I, in vol. VIII of Camb. Hist.), by A. W. Ward. This volume contains an excellent bibliography of Dryden, by Henry B. Wheatley.

For discussion of Orrery's works, see

Roger Boyle, Earl of Orrery und seine Dramen zur Geschichte des heroischen Dramas in England, von Eduard Siegert. (Wiener Beitrd̈ge zur englischen Philologie, XXIII). Wien und Leipzig, 1906.

For discussion of English heroic drama, see P. Holzhausen, Dryden's heroisches Drama (Englische Studien, vols. XIII, Heilbron, 1889; XV-XVI, Leipzig, 1891-1892); L. N. Chase, The English Heroic Play, New York, 1903; C. G. Child, The Rise of the Heroic Play (Modern Language Notes, Baltimore, 1904); and J. W. Tupper, The Relation of the Heroic Play to the Romances of Beaumont and Fletcher (Publications of the Modern Language Association of America, Baltimore, 1905). 
For other references as to Dryden and the English heroic drama, see Wheatley's bibliography, already cited.

The text of The Rehearsal, with key to the passages of drama which it parodies, is accessible in Arber's series of English Reprints:

* George Villiers, second Duke of Buckingham. The Rehearsal . . . with illustrations from previous plays, etc. Carefully edited by Edward Arber. London, 1868.

The Rehearsal is included in Selected Dramas of John Dryden ... edited with introduction and notes by George $R$. Noyes. Chicago, New York [1910].

\section{CHAPTER V}

Etherege.

* The Works of Sir George Etheredge, Plays and Poems, edited, with critical notes and introduction by A. Wilson Verity, 1888.

Edmund Gosse's valuable article on 'Sir George Etheredge,' in his Seventeenth-Century Studies, I883, pp. 233-265, deserves especial notice on account of its recognition of the importance of a dramatist who had not then received adequate critical attention.

Etherege's Letterbook, effectively quoted by both Gosse and Verity, is in the British Museum.

A considerable study (pp. 278) of Etherege is Sir George Etheredge, sein Leben, seine Zeit und seine Dramen, von Vincenz Meindl (Wiener Beiträge zur englischen Philologie, XIV). Wien und Leipzig, rgor.

Wycherley.

* William Wycherley, edited, with an introduction and notes, by W. C. Ward. Unexpurgated edition (Mermaid Series), 1888.

Wycherley's plays are accessible also in The Dramatic Works of Wycherley, Congreve, Vanbrugh, and Farquhar. With biographical and critical notices by Leigh Hunt, I840. (Other editions, I849 and I85I.) Leigh Hunt's work, though now superseded by later critical editions of the separate dramatists, is significant both because it was long a convenient standard 
of reference and because it prompted Macaulay's review essay on the Comic Dramatists of the Restoration, sometimes entitled Leigh Bunt.

A study (pp. 74) of Wycherley, with especial attention to Molière's influence on his plays, is William Wycherley's Leben und dramatische Werke. Mit besonderer Berlicksichtigung von Wycherley als Plagiator Molière's. Von Dr. Johannes Klette. Münster, $\mathbf{1 8 8 3}$.

Shadwell.

* Thomas Shadwell, edited, with an introduction and notes, by George Saintsbury (Mermaid Series). London and Now York [1903]. This excellent edition includes only The Sullen Lovers, A True Widow, The Squire of Alsatia, and Bury Fair.

Quotations from plays not in Saintsbury's edition are from the original editions of the separate plays.

A review of Shadwell's dramatic works, 'attempting to put the reputation of this author on its true level, and vindicate his memory from that charge of dulness which hangs over it,' and containing considerable excerpts from the plays, appeared in 1828 , in The Retrospective Review, Second Series, vol. II, pp. $55-96$.

An article on Thomas Shadwell in two sections, the latter dealing chiefly with The Lancashire Witches, appeared in 1873 , in The New Monthly Magazine, vol. III, New Series, pp. 292297 ; 353-361.

\section{CHAPTER VI}

For bibliographical commentary on Dryden, see Notes to Chapter IV.

Quotations from Thomas Rymer's critical works are taken from the original editions whose titles and dates are indicated in the main text. Selections from Rymer's treatises on the drama are given in Critical Essays of the Seventeenth Century. Edited by J. E. Spingarn. 3 vols. Oxford, I908-1909. Vols. II and III of this excellent work include many passages representative of dramatic criticism during the Restoration period. 
Quotations from Saint-Évremond's critical writings are from the I714 London edition of his Works, ' Made English from the French Original,' and containing a life of the author by P. Des Maizeaux. Saint-Évremond's Euvres Meslées had appeared in a two-volume London edition in 1705 , two years after his death. For other editions, see Sir Frank T. Marzials's article on Saint-Évremond in Dict. Nat. Biog. and the entries in the British Museum catalogue.

Lee.

Quotations from Lee's plays are taken from the original editions of the separate plays. The Yale University Library has an edition of The Works of Mr. Nathaniel Lee, in one Volume [containing I3 tragedies], I694 [variously dated separate title-pages]. This antedates the editions of Lee's Works cited in the Dict. Nat. Biog. and in the Camb. Hist. bibliography. There is no recent reprint of Lee's complete dramatic works. For critical treatises, see Camb. Hist. bibliography, vol. VIII, pp. 437-438.

Otway.

* Thomas Otway, with an introduction and notes, by the Hon. Roden Noel. Unexpurgated edition (Mermaid Series), 1888.

The Orphan and Venice Preserved, by Thomas Otway, edited by Charles F. McClumpha (Belles-Lettres Series), Boston, U. S. A., and London [1908]. This edition contains useful notes and bibliography.

Edmund Gosse's excellent essay, Thomas Otway, which originally appeared in The Cornhill Magazine, December, $\mathrm{I} 877$, is reprinted in his Seventeenth-Century Studies, 1883, pp. 269-305.

\section{CHAPTER VII}

The field of Restoration Pastoral drama is admirably surveyed in

English Pastoral Drama, from the Restoration to the date of the publication of the "Lyrical Ballads" (1660-1798), by Jeannette Marks [1908]. An unusually full bibliography increases the merits of this work. 
The works of many of the minor playwrights mentioned in this chapter have not had recent critical reprint. The Dram. atists of the Restoration Series, edited by James Maidment and W. H. Logan, includes the dramatic works of John Crowne, 4 vols., Edinburgh and London, 1873-1874; and John Lacy, Edinburgh and London, 1875. The dramatic work of Mrs. Behn is represented in The Plays, Histories, and Novels of the ingenious Mrs. Aphra Behn. With Life and Memoirs. 6 vols. 1871 .

An edition of The Dramatic Works of Sir Charles Sedley, 2 vols., appeared in 1776; and of Southerne's Plays, 3 vols., in 1774. Settle is the subject of a special monograph, Elkanah Settle, his life and works. By F.C. Brown, Chicago, 1910. Mrs. Philips is the subject of an essay, 'The Matchless Orinda,' in Gosse's Seventeenth-Century Studies, I883, pp. 205-230.

For further bibliographical material concerning minor Restoration dramatists, see bibliographies to chaps. V, VI, and VII, in vol. VIII of Camb. Hist. For further critical material see these chapters and Ward.

\section{CHAPTER VIII}

For bibliographical commentary on the Collier controversy, see Notes to Chapter IX.

\section{Congreve.}

* William Congreve, edited by Alex. Charles Ewald (Mermaid Series), 1887.

The Comedies of William Congreve, with an introduction by G. S. Street (English Classics, edited by W. E. Henley). 2 vols. 1895 .

William Congreve, with introduction by William Archer (Masterpieces of the English Drama, F. E. Schelling, General Editor). New York, Cincinnati, Chicago [1912]. This omits The Old Bachelor. The excellent introduction includes an extended analysis of the dramatic structure of Congreve's plays.

A valuable critical biography is Life of William Congreve, by Edmund Gosse (Great Writers Series), 1888. This contains 
a bibliography by John P. Anderson. A considerable study (pp. I79) of Congreve is William Congreve, sein Leben und seine Lustspiele, von D. Schmid (Wiener Beiträge zur englischen Philologie, VI). Wien und Leipzig, 1897.

A significant interpretation of Congreve's comedy is given in George Meredith's Essay on Comedy and the Uses of the Comic Spirit, originally delivered as a lecture, first published in The New Quarterly Magazine, April, 1877, and printed in book form, 1897 .

Vanbrugh.

* Sir John Vanbrugh, edited, with an introduction and notes, by A. E. H. Swaen (Mermaid Series), 1896. This includes only the chief plays.

Sir John Vanbrugh, edited by W. C. Ward. 2 vols. 1893. This full and valuable critical edition includes a reprint of Vanbrugh's $A$ Short Vindication of the Relapse and the Provok'd Wife, from Immorality and Profaneness.

A considerable study (pp. I99) of Vanbrugh is John Vanbrughs Leben und Werke. Von Max Dametz (Wiener Beiträge zur englischen Philologie, VII). Wien und Leipzig, 1898.

Farquhar.

George Farquhar, edited, with an introduction and notes, by William Archer (Mermaid Series), London and New York [1906]. This includes only the chief plays. The introduction is valuable.

The Dramatic Works of George Farquhar, edited, with life and notes, by Alex. Charles Ewald. 2 vols. 1892. [Vol. II revised by Robert W. Lowe. Both volumes actually appeared in $189 \mathrm{r}$.]

The Temple Dramatists Series includes The Beaux-Stratagem ... edited with a Preface and Notes by H. Macaulay Fitzgibbon. r898.

A considerable study (pp. 372) of Farquhar is George Farquhar, sein Leben und seine Original-Dramen, von Dr. D. Schmid (Wiener Beiträge zur englischen Philologie, XVIII). Wien und Leipzig, 1904.

The plays of the three dramatists discussed in this chapter are accessible in Leigh Hunt's edition, The Dramatic Works of 
Wycherley, Congreve, Vanbrugh, and Farquhar (see Notes to Chapter V, under Wycherley). A critical review of the four dramatists grouped in Leigh Hunt's edition is included in * Lectures on the English Comic Writers. By William Hazlitt. 1819. (Lecture IV. On Wycherley, Congreve, Vanbrugh, and Farquhar, pp. 133-I76). A very recent and extensive treatment of Etherege and the four dramatists just named is given in The Comedy of Manners, by John Palmer, rgr3.

\section{CHAPTER IX}

The Collier Controversy.

The bibliography to chap. VI in vol. VIII of Camb. Hist. contains a special section (pp. 432-434) entitled ' Jeremy Collier and the Controversy concerning the Morality of the Stage.' A good running account of the controversy is in Edmund Gosse's Life of William Congreve, chap. III.

Colley Cibber.

Quotations from Colley Cibber's plays are taken from the original editions.

Colley Cibber's Apology (1740) is best consulted in

* An Apology for the Life of Mr. Colley Cibber, written by himself. A new edition with notes and supplement, by Robert W. Lowe. 2 vols. 1889. This includes also reprints of James Wright's Historia Histrionica (1699), and of Anthony Aston's A Brief Supplement to Colley Cibber, Esq.: his Lives of the late Famous Actors and Actresses. Mr. Lowe's fidelity to Cibber's text preserves the full vitality of the original, while his valuable annotations are a safeguard against numerous uncertainties or inaccuracies in Cibber's statements.

Mrs. Centliore.

Mrs. Centlivre's plays are accessible in The Dramatic Works of the celebrated Mrs. Centlivre, with a New Account of her Life. 3 vols. 1872. This is a reprint of the edition of $1760-1761$.

A considerable study of her comedies by Robert Seibt is presented in ( $\mathrm{I}$ ) Die Komődien der Mrs. Centlivre. Halle a. 
S. 1909. This section (pp. 58) is essentially a summary of plots and characters; (2) articles in Anglia, Halle a. S., XXXII (I909), 434-480, and XXXIII (I9ro), 77-II9. These sections present a critical study of the comedies.

Steele.

Richard Steele, edited, with an introduction and notes, by G. A. Aitken (Mermaid Series), London and New York, I894. This excellent edition contains, in addition to the chief plays, two fragments, The School of Action, and The Gentleman, and an appendix which reprints various documents concerning Steele's relations with the theatre.

A very valuable and exhaustive critical biography of Steele is Life of Richard Steele, by George A. Aitken. 2 vols. 1889. A copious bibliography is given in vol. II, pp. $387-428$.

A briefer biography is Richard Steele, by Austin Dobson (English Worthies Series, edited by Andrew Lang), 1886. For further material, see bibliography to chap. II in vol. IX (pp. 439-443) of Camb. Bist.

\section{CHAPTER $\mathrm{X}$}

Rowe.

* The Fair Penitent and Jane Shore, by Nicholas Rowe, edited by Sophie Chantal Hart (Belles-Lettres Series). Boston, U. S. A., and London, 1907. This contains a useful introduction and bibliography.

Quotations from other plays of Rowe are from The Dramatick Works of Nicholas Rowe. 2 vols. I720.

Addison.

Quotations from Cato are from the original edition of I7I3. 'Addison's Cato' is the subject of one of the discussions (pp. 39-70) in Famous Plays, with a discourse by way of prologue on The Playhouses of the Restoration. By J. Fitzgerald Molloy. 1886. [The first ' discourse' in this volume is actually entitled 'Congreve's Love for Love,' but deals primarily with the 'Playhouses of the Restoration.'] 
Addison's more important critical utterances on drama and opera are conveniently grouped in *Addison, Selections from Addison's papers contributed to the Spectator, edited with introduction and notes by Thomas Arnold (Clarendon Press Series, 1866, etc.). Oxford.

A considerable study of Addison is included in Le Public et les Hommes de Lettres en Angleterre au dix-huitième Siècle, 1660-1744, par Alexandre Beljame. Paris, 1883. [Deuxième édition augmentée d'un Index. Paris, 1897.] The first chapter of this work, 'Dryden et Le Théatre' (pp. I-I43), contains much valuable material concerning Restoration drama, and the bibliography (pp. 415-507, 1897 edition) of the entire work is full and precise.

A convenient biography is Addison, by W. J. Courthope (English Men of Letters Series). 1884. For further bibliographical material concerning Addison see bibliography (pp. 434-439) to chap. II in vol. IX of Camb. Hist.

\section{CHAPTER XI}

For full account and bibliography of English dramatic translations from Pierre and Thomas Corneille and Racine, see Corneille and Racine in England, by Dorothea Frances Canfield. New York and London, 1904.

For contemporary accounts of eighteenth-century pantomimes, see John Weaver's History of the Mimes and Pantomimes, 1728; Colley Cibber's A pology, 1740 [Lowe edition, II, $179 \mathrm{ff}$.$] ; Thomas Davies's Memoirs of the Life of David Garrick,$ I780, vol. I, chap. X; John Jackson's History of the Scottish Stage, Edinburgh, I793 [especially the account of John Rich, pp. $363-369]$.

Gay.

Quotations from The Beggar's Opera are from the first edition of 1728 of $\cdot$ which there are different impressions. The King's Library, edited by Professor Gollancz, contains a convenient reprint of The Beggar's Opera, edited by G. Hamilton Macleod, with preface, notes, and bibliography, 1905 . 
' John Gay's Beggar's Opera' is the subject of a discussion (pp. 73-100) in Molloy's Famous Plays, 1886. A critical study and reprint of Gay's operas is John Gay's Singspiele mit Einleitung und Anmerkungen ... von Gregor Sarrazin. Weimar, 1898 (pp. xxxii + 209). A noteworthy recent volume is "Polly Peachum," being the story of Lavinia Fenton (Duchess of Bolton) and "The Beggar's Opera," by Charles E. Pearce [r9r3]. This presents much material drawn from newspapers and other contemporary sources, and contains a condensed ' List of Authorities,' pp. 373-376.

\section{CHAPTER XII}

Except in the case of Lillo, quotations from plays in Chapter XII are taken from the original editions of the individual plays.

A considerable study of Young is Le Poète Edward Young (I683-I765), Etude sur sa Vie et ses Euvres, par W. Thomas. Paris, r9or. An extensive study (pp. 678) of Thomson is James Thomson, sa Vie et ses Euvres, par Léon Morel. Paris, 1895. For further bibliographical information see bibliographies in vol. IX of Camb. Hist.: of Young (chap. VII), p. 458; of Thomson (chap. V), pp. 446-450.

Voltaire and English Drama.

A most scholarly and significant study of Voltaire's relation to English drama and dramatic criticism is Shakespeare and Voltaire, by Thomas R. Lounsbury [vol. II in Lounsbury's Shakespearean Wars]. New York and London, 1902.

The present writer's bibliography to chap. IV in vol. $\mathrm{X}$ of Camb. Hist. includes a special section, 'English Adaptations of Voltaire performed on the English Stage, I 734-I 776,' which presents a chronological list of English versions of Voltaire's dramas and supplies some bibliographical references concerning his relation to English drama.

Lillo.

* The London Merchant, or The History of George Barnwell, and Fatal Curiosity, by George Lillo, edited by Adolphus William Ward (Belles-Lettres Series). Boston, U. S. A., and 
London, 1906. This admirable edition has a bibliography and an introduction which is a notable study of Lillo's work and its influence on Continental drama.

An 'Inaugural Dissertation' by Leopold Hoffman is George Lillo (1693-1739), Marburg, 1888.

Moore.

Quotations from Moore's plays are from the original editions. His collected Poems, Fables, and Plays appeared in 1756 . An 'Inaugural-Dissertation' by Hugo Beyer is Edward Moore. Sein Leben und seine dramatischen Werke. Leipzig, 1889.

Fielding.

\section{CHAPTER XIII}

* The Complete Works of Henry Fielding, Esq. With an Essay on the Life, Genius and Achievement of the Author, by William Ernest Henley. Plays and Poems in five volumes [vols. VIII-XII]. New York [1902].

A convenient reprint of Tom Thumb is in Burlesque Plays and Poems. With an introduction by Henry Morley (Morley's Universal Library). London and New York, 1885. A more critical edition is Fielding's Tom Thumb. Mit Einleitung herausgegeben, von Felix Lindner (Englische Textbibliothek, IV). Berlin, I899.

A considerable study (pp. 186 ) is Henry Fieldings dramatische Werke. Litterarische Studie von Dr. Felix Lindner. Leipzig \& Dresden, 1895 .

A useful biography of Fielding, in which much of the first two chapters deals with his dramatic work, is Fielding, by Austin Dobson (English Men of Letters Series). 1883. A recent work (pp. 326) is Henry Fielding, a Memoir, by G. M. Godden. 19ro. For further bibliographical information see bibliography (pp. 4I3-4I8) to chap. II in vol. X of Camb. Hist.

Carey.

* The Dramatick Works of Henry Carey appeared in a collected edition in 1743. A convenient reprint of Chrononhotonthologos is in Henry Morley's Burlesque Plays and Poems (see above, under Fielding). 
The Licensing Act.

A full and scholarly account of the causes leading to the Licensing Act is given in The Struggle for a Free Stage in London, by Watson Nicholson. Boston and New York [also London], 1906. See especially chap. III. A very recent work of considerable range is Censorship in England, by Frank Fowell and Frank Palmer [1913].

Garrick.

\section{CHAPTER XIV}

Quotations from Garrick's plays are from the original editions of the individual plays. The present writer's bibliography to chap. IV in vol. X of Camb. Hist. presents separate lists of Garrick's plays and dramatic adaptations, and some indication of critical and bibliographical material. Among the more recent volumes listed is Garrick and His Circle, by Mrs. Clement Parsons. New York and London, 1906. This valuable study has a list of 'Some Works Consulted,' pp. xvii-xx. An excellent work with much new material is A Cosmopolitan Actor, David Garrick and His French Friends, by Frank A. Hedgcock [1912]. ['A very free rendering and adaptation' of Hedgcock's David Garrick et ses Amis Français. Paris, IgIr.] The London edition contains (pp. 432-436) 'A List of the Principal Works Quoted or Referred to,' and a section of the Appendix (pp. 426-429), ' Garrick and the Plays of Shakespeare,' which records the Shakespearean dramas acted or produced by Garrick.

A considerable account of acting during the Garrick period is given (pp. 375-4I $)$ in vol. V ( 1909 ) of A History of Theatrical Art, in Ancient and Modern Times, by Karl Mantzius. Authorised Translation by Louise von Cossel. [Other sections in vol. V cover 'The Betterton Period' (pp. 306-337) and 'The Cibber Period ' (pp. 338-374).] For early accounts of Garrick and the theatre of his day, see especially the two works by Thomas Davies: Memoirs of the Life of David Garrick, Esq. 2 vols., I780, and Dramatic Miscellanies, 3 vols., 1784 [vol. II dated 1783$]$. 


\section{Adaptations of Shakespeare's Plays.}

For broader discussion of the general subject of which the history of Garrick's stage-versions of Shakespeare forms but one part, see especially chap. VIII, 'Alterations of Shakespeare's Plays,' in Shakespeare as a Dramatic Artist, by Thomas R. Lounsbury (vol. I in Lounsbury's Shakespearean Wars). New York and London, 1902. A very large part of this entire volume is directly concerned with the history of Shakespearean criticism during the period covered by the present work. A considerable study (pp. 190) surveying the Restoration period as well as the eighteenth century is Alterations and Adaptations of Shakespeare, by Frederick W. Kilbourne. Boston [U. S. A.], 1906. A most extensive reference work (pp. 729) for bibliographical information as to Restoration and eighteenth-century editions and versions of Shakespeare's plays is Shakespeare Bibliography, by William Jaggard. Stratford-on-Avon, rgrr.

For works concerning Voltaire's relation to the English stage during the Garrick era, see Notes to Chapter XII, under Voltaire and English Drama. For discussion of English versions of plays by Pierre and Thomas Corneille and Racine during this period, see especially chap. XV in Corneille and Racine in England, by Dorothea Frances Canfield, New York and London, 1904.

Quotations from Dr. Johnson's Irene are from the original edition of 1749. An admirable bibliography of Johnson by David Nichol Smith is in vol. X of Camb. Hist. (pp. 459-480). 'Dr. Johnson's Irene' is the subject of a discussion (pp. 103126) in Molloy's Famous Plays, 1886.

\section{Home.}

Quotations from Home's Douglas are from the original London edition of 1757 . The 1760 edition of his Dramatic Works contains only Douglas, Agis, and The Siege of Aquileia. His Dramatic Works appeared in a two-volume Edinburgh edition in 1798. A more recent edition is The Works of John Home now first collected [with Henry Mackenzie's 'Account of the Life and Writings of John Home']. 3 vols. Edinburgh. 1822. The 'Account' was also printed separately, Edinburgh, 1822 . 
For discussion of the controversy over Douglas, see sect. XVII (pp. 3I3-330) in John Jackson's History of the Scottish Stage, Edinburgh, 1793. The Bodleian Library contains a valuable collection of the controversial pamphlets. 'Douglas' is the subject of chap. VI (pp. 85-92) in The Annals of the Edinburgh Stage, with an account of the Rise and Progress of Dramatic Writing in Scotland, by James C. Dibdin. Edinburgh, 1888 .

Foote.

\section{CHAPTER XV}

Quotations from Foote's plays are from The Dramatic Works of Samuel Foote, Esq. 4 vols. [ $1787-\mathrm{r} 788$ ?] This collection is made up from different editions of the separate plays with variously dated individual title-pages and separate pagination.

A considerable account of Foote is Samuel Foote, a biography, by Percy Fitzgerald. I9ro. For further bibliographical material see bibliography to chap. IV in vol. X of Camb. Hist. (pp. 430-43I).

The plays of Arthur Murphy are accessible in The Works of Arthur Murphy, Esq. 7 vols. 1786. The plays of George Colman the Elder are accessible in The Dramatick Works of George Colman. 4 vols. I777. Quotations in the present volume are from the original editions of the separate plays. For bibliographical material concerning these and other authors discussed in Chapter XV, see the present writer's bibliography to chap. IV in vol. X of Camb. Hist.

\section{CHAPTER XVI}

A definite discussion of English sentimental drama is The Development of English Sentimental Comedy in the Eighteenth Century, by Osborn Waterhouse, in Anglia, Halle a. S., XXX (1907), 137-172, 269-305. The Introductions, in the Belles-Lettres Series, to Ward's Lillo (see Notes to Chapter XII, under Lillo) and Austin Dobson's Goldsmith (see Notes to Chapter XVII) contain brief, but valuable, references to sentimental drama in England and France. 
Goldsmith's important Essay on the Theatre; or, A Comparison between Laughing and Sentimental Comedy, published originally in the Westminster Magazine, December, 1772 , is reprinted in Austin Dobson's edition of Goldsmith's plays in the Belles-Lettres Series, pp. 125-130.

\section{Kelly and Cumberland.}

Quotations from the plays of Hugh Kelly and Richard Cumberland are from the original editions of the separate plays. Kelly's plays are accessible in The Works of Hugh Kelly. To which is prefixed the Life of the Author. 1778.

The most remarkable account of Cumberland is his own autobiography: Memoirs of Richard Cumberland. Written by himself. 1806. Quotations in the present work are from the convenient two-volume octavo edition of 1807. A year after Cumberland's death, his Memoirs was drawn upon with a freedom that Sir Fretful Plagiary might have resented in The Life of Richard Cumberland, Esq. By William Mulford. I812. An earlier account of Cumberland is the chapter (XLVIII) by Thomas Davies in his Memoirs of the Life of David Garrick, Esq. (1780 edition, vol. II, pp. 263-278). Many of Cumberland's letters which confirm the unconscious self-revelations of the Memoirs are in The Private Correspondence of David Garrick with the most celebrated persons of his time. 2 vols. 1831-1832. See especially, I, 284-285, 380-382, 387, 425-428, 434, 437438, 551-553; II, I26, 200, 206, 282-286. ' Richard Cumberland' is the subject of an essay (pp. 192-232) in Eighteenth Century Studies. By Francis Hitchman. 1881 .

\section{CHAPTER XVII}

Goldsmith.

* The Good Natur'd Man and She Stoops to Conquer, by Oliver Goldsmith. The introduction and biographical and critical material by Austin Dobson, the text collated by George P. Baker (Belles-Lettres Series). Boston, U. S. A., and London [1903]. This admirable edition contains suggestive notes, introduction, and bibliography. 
A useful recent edition is The Plays of Oliver Goldsmith [cover-title]. The Good-Natured Man, She Stoops to Conquer, by Oliver Goldsmith, edited with introduction and notes by Thomas H. Dickinson (Riverside Literature Series). Boston, New York, Chicago [1908]. Convenient recent editions of the separate plays include Goldsmith, The Good-Natur'd Man, edited with introduction and notes by G. G. Whiskard. Oxford, 1912, and She Stoops to Conquer, edited with introduction and notes by G. A. F. M. Chatwin, Oxford, ror2.

Among biographies of Goldsmith are The Life and Adventures of Oliver Goldsmith. A biography : in four books. By John Forster. 1848;- Goldsmith, by William Black (English Men of Letters Series). 1878; - Life of Oliver Goldsmith. By Austin Dobson (Great Writers Series). 1888 [with bibliography by John P. Anderson] ; - The Life of Oliver Goldsmith, by Frank Frankfort Moore. I9ro. [New York, rgrr.] A very recent account of Goldsmith by Austin Dobson is chap. IX in vol. X of Camb. Hist., which is supplemented with a bibliography (pp. 480-484).

' Goldsmith's She Stoops to Conquer' is the subject of a discussion (pp. 129-r74) in Molloy's Famous Plays, 1886. An ' Inaugural-Dissertation (pp. I r6) on Goldsmith als Dramatiker,' by Arthur Mendt, was published at Leipzig in rgr.

A considerable account of the exordium to Samuel Foote's The Handsome Housemaid, or Piety in Pattens is in vol. I, pp. I4-22, of The History of the Theatres of London [by Walley Chamberlain Oulton, see 'Dedication']. 2 vols. I796. This useful work, it may here be noted, contains 'An Annual Register of all the new and revived Tragedies, Comedies, Operas, Farces, Pantomimes, \&c. that have been performed at the Theatres-Royal, in London, from the year I77I to I795.' It is a continuation of Benjamin Victor's History of the Theatres of London, I77 I, which, in turn, is a continuation of Victor's previous History, 2 vols., 1761 . These three works cover the years from 1730 to 1796 . For fuller details see bibliography to chap. IV in vol. X of Camb. Hist. (pp. 442-443). 


\section{CHAPTER XVIII}

Sheridan.

Quotations from The Rivals and The Critic are from the first printed editions of the separate plays. Quotations from The School for Scandal are from the text, based on Sheridan's manuscript, in *Sheridan's Plays now printed as he wrote them, and his mother's unpublished comedy, A Journey to Bath. Edited by W. Fraser Rae. 1902. Sheridan's continued indifference toward the question of revising his text for publication helps to account for numerous textual variants in editions published during his lifetime. Five years after his death, appeared The Works of the late Right Honourable Richard Brinsley Sheridan ['Advertisement' signed by Thomas Moore]. 2 vols. London. John Murray, Albemarle-Street; James Ridgway; and Thomas Wilkie. I821. This work, from its association with the name of Sheridan's biographer, acquired an authority which Moore's own confessions show was unwarranted. In lieu of the 'Life' which was to accompany the work, Moore finally contributed an apologetic 'Advertisement' which, supported by other definite testimony, shows how nominal was his connection with the work on Sheridan which was published during his protracted residence on the Continent. The so-called 'Moore edition,' however, has been the ultimato source of most subsequent reprints of Sheridan's plays.

An excellent reprint of the first edition of The Rivals is in The Rivals, with an introduction and notes by Joseph Quincy Adams, Jr. (Riverside Literature Series). Boston, New York, Chicago [rglo]. A recent annotated edition of The Rivals is Sheridan, The Rivals, edited with introduction and notes by T. Balston. Oxford, rgr3. An annotated edition of the two major comedies is The Rivals and The School for Scandal, edited with introduction and notes by Will David Howe (MaCmillan's Pocket American and English Classics). New York and London, 1907. 'Sheridan's Rivals and School for Scandal' is the subject of a discussion (pp. 177-218) in Molloy's Famous Plays. A convenient annotated edition of Sheridan's collected plays is The Dramatic Works of Richard Brinsley Sheridan, 
with an introduction by Joseph Knight. Oxford, etc. [1906]. For references as to editions of Sheridan's plays prior to 1906, see 'A Bibliographical Note' (pp. cxi-cxvii) in the present writer's The Major Dramas of Richard Brinsley Sheridan, The Rivals, The School for Scandal, The Critic, edited with introductions and notes (Athenceum Press Series, G. L. Kittredge and C. T. Winchester, General Editors). Boston, etc. [1906]. This work supplies detailed critical and bibliographical material which it has seemed unnecessary to reproduce here.

Among numerous accounts of Sheridan's life may be mentioned a few representative works. Memoirs of the Life of the Right Honourable Richard Brinsley Sheridan. By Thomas Moore. I825 [Third edition, 2 vols., 1825]. This work handles somewhat carelessly its abundant materials, but remains the most important of the earlier biographies. 'A Biographical Sketch' by Brander Matthews in his Sheridan's Comedies, The Rivals and The School for Scandal. Boston [also London], 1885. [Reprinted with slight changes, New York, I904.] This is an interesting briefer account. Life of Richard Brinsley Sheridan, by Lloyd C. Sanders (Great Writers Series). London, etc. [189o]. This contains much useful material, including a bibliography by John P. Anderson. Sheridan, a biography, by W. Fraser Rae. 2 vols. 1896 . This work, by the author of the Sheridan article in Dict. Nat. Biog. and the editor of Sheridan's Plays now printed as he wrote them, is an extensive and important study based largely on the Sheridan manuscripts and other authoritative sources of information. Sheridan, from new and original material; including a manuscript diary by Georgiana Duchess of Devonshire, by Walter Sichel. 2 vols. r909. This elaborate work supplements Fraser Rae's biography, enlarging the field with some useful new matter, but it is marred by frequently ill-founded claims to originality and by errors especially numerous in the untrustworthy bibliography. 


\section{INDEX}

Individual plays are listed separately under their own titles, with the names of their authors in brackets. In the case of Restoration and eighteenthcentury dramatists, references under individual author-headings are given, as a rule, (1) to the chief discussion of their dramatic work, (2) to additional comments either on general or specific aspects of their dramatic work, and (3) to commentary on their critical views of drama and on various incidental topics. Important, or relatively important, references are indicated by heavy-faced page numerals; references to footnotes in the main text, by 'n.'; to the 'Bibliographical Notes' (pp. 315-340), by 'BIBL.,' followed by the page numeral. With a few exceptions, authors and titles cited only in the 'Bibliographical Notes' are not separately listed in this Index, but various critical editions, theses, and other works may be located through the general bibliographical references given under the individual dramatists or topics concerned.

Abdelazar (Mrs. Behn), 114 .

Actaeon and Diana (Cox), ro7.

Actors,

creation of two companies of, under

Charles II, 2 ; account of, during dramaticinterregnum, 14-16; after the Restoration, 30-3r.

Actors Remonstrance, The (pr. 1643), 15-16; BIBL., 321.

Actresses,

sporadic appearances of, before the Restoration, 3; regularly employed on Restoration stage, 3 ; plays acted wholly by, 34, 42; coarse epilogues spoken by, 42 .

Addington, William, Kelly's School for Wives produced under his name, 272.

Addison, Joseph, dramatic work and criticisms, 179182, 184; other references to Cato, 163, 189, 198, 216; to Rosamond, 172, 172 n.; protests against perversion of Lear, 115 ; indebtedness of Steele's Lying Lover to, 162, 162 n.; remarks on opera, 171, 171 n.; prologue and epilogue by, 179; attacks gambling, 210; BIBL., 330-331.
Adventures of Five Hours, The (Tuke), $6,45,109$.

Esop (Vanbrugh), 133.

Afterpieces, dramatic, development and influence of, 247249.

Agamemnon (Thomson), 197.

Agis (Home), 240.

Aitken, G. A., his edition of Steele cited, $163 \mathrm{n}$.; BIBL., 330.

Albion and Albanius, opera by Dryden, 94 ; its Preface cited, 171.

Albion Queens, The (original title, The Island Queens, John Banks), 117.

Alchemist, The (Jonson), revivals of, 38,183 ; Garrick as Abel Drugger in, 245 .

Alcibiades (Otway), 99.

Alexander the Great, The Death of (main title, The Rival Qweens, Lee), 96-97, 97 n., $117 \mathrm{n}$.

Alfred (Home), 240-241.

All for Love (Dryden), 90-92, 53, $68,88,95,96$, ror.

All in the Wrong (Murphy), 255.

Almansor and Almahide, or The Conquest of Granada by the Spaniards 
Almanzor and Almahide - Cont. (Dryden), 62-63, 60; its Epilogue, 63-64; Almanzor burlesqued in The Rehearsal, 64-65.

Almida,

Madame Celesia's adaptation of Voltaire's Tancrede, 236 .

Alonzo (Home), 240.

Alsira,

Hill's adaptation of Voltaire's Alzire, 200.

Alzuma (Murphy), 237.

Ambitious Step-Mother, The (Rowe), I73;

its Epilogue cited, r69; its Prologue cited, 177.

Amboyna (Dryden), 67.

A morous Prince, The (Mrs. Behn), 114.

Amphitryon (Dryden), 93.

Andromache,

Crowne's adaptation of Racine, II 2.

Andronicus Comnenius (Wilson), 39. Antony and Cleopatra (Sedley), iri.

Antony and Cleopatra (Shakespeare), contrasted with All for Love, 90-92.

Appius (Moncrief), 240.

Arber, Edward,

his reprint of The Rehearsal cited, 55 n., 65 n.; BIBL., 324.

Arbuthnot, John, collaborates with Gay and Pope, roo.

Arden of Feversham (Lillo), 208.

Arsinoë, opera by Motteux, I7I.

Artifice, The (Mrs. Centlivre), I54.

Artificial Comedy of the Last Century, On the , Lamb's essay, 7-10 ; BIBL., 320.

Assignation, The (Dryden), 67.

As You Like It, revival of, 232 ; a note on Touchstone, $78 \mathrm{n}$.

Atheist, The (Otway), roo n.

Athelwold (Hill), $200 \mathrm{n}$.

Aureng-Zebe (Dryden), 68;

its Prologue cited, 68, 90 .

Author, The (Foote), 253.
Author's Farce, The (Fielding), 214, 219.

Ayscough, George Edward, his Semiramis adapted from Voltaire's Semiramis, 236.

Baillie, Joanna,

Elizabethan tendencies in, 176.

Baker, H. B.,

his History of the London Stage, BIBL., 318.

Baker, Thomas, Prologue to his Tunbridge-Wells cited, II6.

Banishment of Cicero, The (pr. r76r, Cumberland), 272.

Banks, John, dramatic work, 117-118, $106 \mathrm{n}$; debt to French romances, 109; continued popularity of his plays, 173, 240; satirized in Tom Thumb, 216; Jones's use of his Unhappy Favourite, 239-240.

Barbarossa (Brown), 239-240.

Baron, Robert,

plays of, published during interregnum, 19.

Barry, Elizabeth,

Restoration actress, I0I, 173.

Barry, Spranger, actor, 234, 240, 245, 256 (with his wife).

Bartholomew Fair (Jonson), revival of, 183 .

Battle of Hastings, The (Cumberland), 274.

Beaumont and Fletcher, (see also Fletcher, John)

'drolls' based on, 18 ; interregnum performances of, 18-19; D'Avenant's early plays resembling, 20; as forerunners of 'heroic drama,' 22, 32 ; Restoration performances of, $35-36,48,58$; eighteenth-century performances of, 173,183 ; Fielding's allusion to, 22r ; popularity of, compared with Shakespeare's, 232 ; Colman's alteration of Philaster, 260; Colman's edition of their dramatic works, 262 ; BIBL., 323 (under J. W. Tupper). 
Beau's Dwel, The (Mrs. Centlivre), 154.

Beauty in Distress (Motteux), 166-167.

Beaux' Stratagem, The (Farquhar), 137-140;

compared with She Stoops to Conquer, 286, $286 \mathrm{n}$.

Beggar's Opera, The (Gay), 189-194, I40,204, 213, 214 ;

Rich's revival of, 246 ; its run compared with that of Sheridan's $D u$ enra, 299-300; BIBL., 331-332.

Behn, Mrs. Aphra, dramatic work, II4-II5; her Emperor of the Moon, 184 ; Continental influences on, 46,109; Southerne's plays founded on her novels, I1 8 ; BIBL., 327.

Bellamira (Thomas Killigrew), 108.

Bellamira, or The Mistress (Sedley), III.

Bellamy, George Anne, actress, 234.

Belphegor (Wilson), 39.

Betterton, Thomas, as actor, 36, 173, 233; as manager, I25, 169; collects Shakespeare material, 177.

Betty, William Henry West, the 'Young Roscius,' 240.

Bickerstaff, Isaac, dramatic work, 257; spelling of his name, $257 \mathrm{n}$.; indebtedness of his Hypocrite to Cibber's Non-Juror, 152.

Biographia Dramatica, cited, 39, 186; BIBL., 316-317.

Biter, The (Rowe), 176.

Blackmore, Sir Richard, protests against the excesses of Restoration drama, I 20, 142; praises Congreve's Mourning Bride, $120 \mathrm{n}$.

Black Prince, The (Orrery), 59.

Bold Stroke for a Wife, $A$ (Mrs. Centlivre), $154,195$.

Bon Ton (Garrick), 254.

Boswell, James, his Life of Johnson cited, 127 n., I 5 I, I5I n., 241 n., 250 n., 25 I n., $284 \mathrm{n}$.
Bottom the Weaver,

a 'droll' founded on A Midsummer Night's Dream, 16.

Bouncing Knight, The, a 'droll' concerning Falstaff, 18.

Boursault, E.,

Vanbrugh's debt to, 133.

Boyle, Roger (Earl of Orrery), dramatic work, 54-55, 55 n.; his Guzman, 45, 45 n.; his Black Prince, 59; his debt to French romances, 109; BIBL., 323.

Bracegirdle, Anne, actress, 173.

Britannia and Batavia (Lillo), 208.

Brome, Richard, as a forerunner of Restoration comedy, 72; Mrs. Behn's debt to, II4.

Brothers, The (Cumberland), 272.

Brothers, The (Young), 195-196.

Brown, John, his Barbarossa, 239-240.

Brutus,

Duncombe's adaptation of Voltaire's tragedy, 200 .

Buckingham, Duke of (George Villiers),

The Rehearsal, 64-66, 55, 55 n., 86, $89,2 I_{3}, 21_{4}, 229,229 \mathrm{n}$.; its influence on Sheridan, 292, 308, 31 I ; BIBL., 324.

Bury Fair (Shadwell), 84, 86.

Busie-Body, The (Mrs. Centlivre), 154.

Busiris (Young), 195;

burlesqued by Fielding, 196, 216.

Butler, Samuel,

his possible share in The Rehearsal, 64.

Caelia (Charles Johnson), 209-210.

Casar Borgia (Lee), 98.

Caius Marius, The History and $\boldsymbol{F a l l}$ of (Otway), 100, 233.

Calderon, his influence on Restoration dram. atists, 45, 79, 109.

Caligula (Crowne), I12, 167.

Calisto (Crowne), 107, 108.

Calypso and Telemackus (Hughes), I 96. 
Cambert, Robert,

French opera of, 44 .

Cambridge History of English Literature, The, BIBL., 315, 317, 319, $323,326,327,329,330,331,332$, $333,334,335,336,338$.

Cambyses (Settle), 113.

Capuchin, The (Foote), 251.

Caractacus (Mason), 243.

Careless Husband, The (Cibber), 150152, 16r ;

Garrick acts in, 229.

Carey, Henry, dramatic work, 216-217, 194, 265; BIBL., 333.

Cato (Addison), 179-182, 183 ;

Fielding's reference to, 163 ; Voltaire's opinion of, 182,198 ; Cibber's comment on, 189 ; satirized in Tom Thumb, 216; BIBL., 330.

Cavalier spirit,

its expression in printed interregnum plays, $19-20$; in early printed Restoration plays, 37 ; in early acted Restoration plays, 36-37; in Etherege's Comical Revenge, 74.

Celesia, Dorothea (Madame), her Almida, adapted from Voltaire's Tancrède, 236.

Censorship, dramatic,

Sir Henry Herbert's position on, $3 \mathrm{I}$; increased strictness of, 147 ; Gay's Polly and other plays prohibited, 193, 222, $222 \mathrm{n}$.; the Licensing Act of 1737, 221-222, 224 ; Thomson's Edward and Eleonora rejected by censor, I97; BIBL., 334 (under The Licensing $A c t)$.

Centlivre, Mrs.,

dramatic work, 153-154; Spanish influence on, 46; BIBL., 329-330.

Chamberlayne, William, his play (Love's Victory) published during interregnum, 19.

Chapman, George,

Tate's adaptation of, II5.

Charles II,

Patent Theatres established under, I-2, 30-3I; his regard for Thomas Killigrew, 34 ; his relation to
French drama, 47, 59, 59 n.; his preference for comedy, 72, $72 \mathrm{n}$.

Cheats, The (Wilson), 38.

Cheats of Scapin, The (Otway), roo.

Chinese Festival, The,

produced by Garrick, 246.

Christian Hero, The (Lillo), 207208.

Chrononhotonthologos (Carey), 216217, I94; BIBL., 333.

Cibber, Colley,

dramatic work, 149-153, 147, 154, 204; other references to his Love's Last Shift, 133-134; to his Careless Husband, 161 ; to his Non-Juror, 257; to his Provoked Husband, 133, 195, 303; his Heroic Daughter, 183; his alteration of King John in Papal Tyranny, 23I-232, 23I n.; his Prologue to Hill's Zara quoted, 200; Spanish influence on his plays, 46; Garrick acts in his plays, 229 ; his influence on Steele's plays, 161, 162, 163. - As historian of drama in his Apology; comments on Lee's Rival Queens, 96-97; on 'dramatic operas,' II 7, I70; on opening of Haymarket Theatre, 132; on Vanbrugh's style, 136 ; on spectacular stage diversions, 168 , 169-1 70; on Italian opera, I 7 I, I 72 ; on pantomimes, $184-186,247$; on Gay's Beggar's Opera, 189; on Fielding's political satires, 221-222; BIBL., 329.

Cibber, Mrs., actress, 234, 245.

Cibber, Theophilus, his Lives of the Poets cited, $206 \mathrm{n}$.; attacks Garrick's Shakespearean versions, 234, $234 \mathrm{n}$.

Cinna's Conspiracy (often, doubtfully, ascribed to Colley Cibber), 183.

Circe (Dr. Charles D'Avenant), I 17 , I 70 .

City Heiress, The (Mrs. Behn), II4.

City Politiques (Crowne), II 2.

Clandestine Marriage, The (Colman and Garrick), 26I-263, 245. 
Claracilla (Thomas Killigrew), revival of, 34 .

Clayton, William, composer of music to Arsinoë, I7I ; to Addison's opera, 172.

Clementina (Kelly), 272.

Cleomenes (Dryden), 93, 94.

Clifford, Martin, assists in The Rehearsal, 64 .

Clinch, Lawrence, his success as Sir Lucius O'Trigger, 294, 299.

Cockpit Theatre, in Drury Lane, early performances at, 30-31.

Coello, Antonio, Spanish dramatist, 45 .

Coffee-House Politician, The (alternative title for Rape upon Rape, Fielding), 214 n., 255.

Cokayne, Sir Aston, plays of, published during interregnum, 19.

Collier, Jeremy,

his Short View of the Immorality, and Profaneness of the English Stage, 121, 142-144, 148; his Defence of the Short View, $123,123 \mathrm{n}$., I45; pamphlet controversy provoked by, 144-145, 147; attitude of Dryden towards, 95, 95 n., 145146; of Congreve, 123, 1 29, 144I45; of Vanbrugh, 144-145; of Steele, 158; other references to, 153, 166, 196, 301 ; BIBL., 329.

Collier, John Payne,

his History of English Dramatic Poetry cited, $18 \mathrm{n}$.

Collier controversy, the, over the immorality of the stage, $12 x, 141-148,95,123,129,153,158$, I66, I96; BIBL., 329.

Collins, William,

his connection with John Home, 242.

Colman, George, the elder, dramatic work, 257-263; his English Merchant, 237; his alteration of Mason's Elfrida, 243 ; his general theatrical and literary career, 262263 ; his productions of Goldsmith's plays, 262, 277, 283 ; BIBL., 336.
Comedy of manners,

Restoration, contrasted with Spanish comedy, 46-47; with Elizabethan, 72-73; Etherege as founder of 'society comedy,' 73 76-77; Congreve as follower of, $76,87,132$; Shadwell in relation to, 84 ; Sheridan in relation to, 87 , 306, 313 .

Comic Dramatists of the Restoration, Macaulay's essay on, 8-10; BIBL., 320.

Comical Gallant, The, or The Amours of Sir John Falstaffe (Dennis), 230, $230 \mathrm{n}$.

Comical Revenge, The (Etherege), 7374, 55, 111 .

Committee, The (Sir Robert Howard), III, III $\mathrm{n}$.

Confederacy, The (Vanbrugh), 135 , I32, 133.

Congreve, William, dramatic work, 122-132; general references to, 37, 47, 53, $71,106,135,136,141,148$, 166 ; as a follower of 'society comedy,' 76, 87; his Millamant compared with Dryden's Melantha, 67; with Cibber's Lady Betty Modish, 150; his Belinda with Cibber's Lady Grave-Airs, I50; his tribute to Wycherley's Plain Dealer, $82-83$; his Mourning Bride praised by Blackmore, $120 \mathrm{n}$.; his part in the Collier controversy, $144^{-146}$; as theatrical manager, 172 ; Queen Anne performances of his plays, 173; Garrick's performances of, 229; his influence on Fielding, 213, 224; on Colman, 259, 259 n.; on Sheridan, 291, 306 ; BIBL., 327-329.

Conquest of Granada by the Spaniards, The (main title, Almanzor and Almahide, Dryden), 62-63,60; its Epilogue, 63-64; Almanzor burlesqued in The Rehearsal, $64-65$.

Conscious Lovers, The (Steele), 163164, 195, $210,248$.

Constant Couple, The (Farquhar), 137; its Prologue cited, 168. 
Constant Nymph, The (Anon.), 108. Constantine the Great (Lee), 98 .

Cooke, William, his comments on Gay's Beggar's Opera, I9I, I93 n.

\section{Coriolanus,}

Tate's adaptation of, II5; James Thomson's version of, 197 ; Dennis's version of, $230,230 \mathrm{n}$.

Corneille, Pierre,

influence of his dramas and dramatic theories on Restoration drama, 49-50, 35, 47, 57, I10; his part in Psyché, 44 ; Dryden's reference to 'Corneille's rhyme,' 63,84 ; Steele's borrowing from, I6r; Queen Anne adaptations of, 183 ; general influence of, 198 ; satirized by Fielding, 216 ; later adaptations of, 235, 239; BIBL., 33 I, 335.

Corneille, Thomas,

his influence on Dryden's Evening's Love, 56-57 ; English versions of his plays, 235, 239 ; BIBL., 331, 335.

Costume,

D'Avenant's early attempts at historical accuracy in, 28-29; increasing attention to, 40-42; expensive 'habits' in operas, 117,170 ; in pantomimes, 187 .

Cotton, Charles, minor Restoration dramatist, I 10. Country Girl, The (Garrick), 80, 300. Country House, The (Vanbrugh), 133. Country Wife, The (Wycherley), 7980, 77, 8I ;

Macaulay on its immorality, 8-9; an alleged source of Sheridan's Duenna, 300; compared with The School for Scandal, 306.

Country Wit, The (Crowne), II 2.

Covent Garden Theatre,

Marforio produced at, 220 ; Garrick's connection with, 228; John Rich's Shakespearean revivals at, 23I ; rivalry with Drury Lane, 234; revival of Murphy's Orphan of China at, 237; Douglas at, 240, 240 n.; Mason's plays produced at, 243 ; secession of actors to, 245 ; Colman as manager of, 262 ; Gold- smith's plays produced at, 262 , 268, 277, 283; Sheridan's plays produced at, 293, 299.

Covent-Garden Tragedy, The (Fielding), 216.

Cowley, Abraham, dramatic work, 37; BIBL., 322.

Cox, Robert, actor and author of 'drolls,' 16,18 ; his pastoral, I07.

Cozeners, The (Foote), 253, 254.

Cradock, Joseph, his Zobeide adapted from Voltaire's Les Scythes, 236.

Craftie Cromwell (pr. 1648, Anon.), I9-20.

Crisp, Samuel (often, erroneously, 'Henry'), his Virginia, 239, 240.

Critic, The (Sheridan), 308-312, 313 ; in connection with The Rehearsal, 66; with Tom Thumb, 2r6; its debt to Fielding's farces, 219, $219 \mathrm{n}$.; its parody of Douglas, 242, 242 n.; its hit at Kelly's sentimental drama, 270; its portrayal of Cumberland as Sir Fretful Plagiary, 272; its relation to Sheridan and Halhed's Jupiter, 292 ; its personal hit, 302 ; BIBL., 339-340.

Cromwell, Oliver, acting 'in Oliver's time,' ${ }_{5}$; interregnum plays attacking him, 19-20; Sir Henry Herbert's mention of, 31 ; early Restoration plays attacking him, 36-37; allusions to, by Etherege, 74 .

Cromwell's Conspiracy (pr. I660), 37.

Cross, W. L., cited as authority, $220 \mathrm{n}$.

Crowne, John, dramatic work, II2-II3; Continental influences on, $46,46 \mathrm{n}$., I09, I I0; royal command to write comedy, 72 n.; his use of blank verse and rhyme, I05, I67; his masque Calisto, 107, 108; his Sir Courtly Nice as a typical fop, 150; BIBL., 327.

Cruelty of the Spaniards in Peru, The (D'Avenant), 27-28. 
Cumberland, Sir Richard, dramatic work, 272-276, 156, 268, 277, 282; as Sheridan's Sir Fretful Plagiary, 310; BIBL., 337.

Cutter of Coleman-Street (Cowley), 37.

Cymbeline,

Colman's revival of, 262.

Cyrus (Hoole), 237.

Cyrus the Great (Banks), 118.

Dance, James, his dramatization of Pamela, 229.

Dancer, John, his translation of Tasso's Aminta, 107-108, 108 n.; of French drama, 110.

Dancourt,

Vanbrugh's debts to, $133,135$.

D'Avenant, Dr. Charles, his Circe (1677), I17, 170.

D'Avenant, Sir William, dramatic work, 20-33, 4I, 43-44, $48,55,105$; his alteration of Macbeth, 5-6, 4I ; of The Tempest (with Dryden), 5, 56, 56 n.; his plays published during interregnum, 19; attacked in The Rehearsal, 64, 64 n.; as laureate, 86; Cibber's account of his introduction of dramatic operas, 117 ; BIBL., 32 I-322.

Davies, Thomas,

his Life of Garrick cited, 187,187 n., 188-189, 212 n., 228 n.; his Dramatic Miscellanies cited, 233 , 233 n.; BIBL., 334.

Debauchees, The (Fielding), 218.

Deborah (Fielding), 218.

Defence of an Essay of Dramatic Poesy, $A$, by Dryden, 60, 93, 93 n.

Dennis, John,

his tragedies, 167; Congreve's letter to, 129,129 n. ; in Collier controversy, I44-145; praises

Congreve, 148; attacks Steele's Conscious Lovers, 163; his essay on operas, 171 .

Destouches, a forerunner of sentimental drama, 264.
Destruction of Jerusalem, The (Crowne), I1 2.

Deuce is in Him, The (Colman), 260. Devil upon Two Sticks, The (Foote), 253.

Dictionary of National Biography, BIBL., 3 I8.

Diderot, Denis,

Lillo's influence on, 207, 207 n., 264.

Dido and A eneas,

Purcell's opera, 44.

Digby, George (Earl of Bristol), his adaptations of Calderon, 45 , Iog.

Discovery, The (Mrs. Sheridan), 260, 292.

Distrest Mother, The (Philips), I79, $183,235,239$;

satirized by Fielding, 216.

Diversions of the Morning, The,

Foote's entertainment, 249.

Dobson, Austin,

his Fielding cited, 223 n.; BIBL., 333; his edition of Goldsmith's plays cited, 265 n., 266 n., 285, 285 n.; BIBL., 337.

Dr. Faustus (Marlowe), comic scenes in, compared with Otway's, 102.

Dodsley, Robert,

his collection of old plays, 238.

Don Carlos (Otway), 99-100, 103.

Don Quixole in England (Fielding), 218.

Doran, John,

his Annals of the English Slage cited, I95 n.; BIBL., 318.

Dorset Gardens Theatre,

its opening, 117; its elaborate spectacles, $\mathbf{1 6 8 .}$

Double-Dealer, The (Congreve), 123125.

Douglas (Home), 240-243 ;

parodied in Sheridan's Critic, 309 , 309 n. ; BIBL., 335-336.

Downes, John, his Roscius Anglicanus cited, 5-6, 6 n., 35-36, 35 n., 38, 39, 41, 41 n., 45, 45 n., 169, r69 n.; BIBL., 3 r9; Knight's reprint of, cited, I $\mathbf{n}_{\text {.; }}$ BIBL., 319. 
Dragon of Wantley, The (Carey), 217. Drama,

(see especially Elizabethan drama, French drama, Restoration drama, etc.) 'modern English drama,' definition of, suggested, I, 2 ; importance of, 12-13 ; formal opening of, 30-3I.

Draper, Matthew, his Spendthrift, 2 Io.

'Drolls,' during dramatic interregnum, 1619, 43 ; BIBL., 321 .

Drummer, The (Addison), I80.

Drury Lane Theatre, earlier known as The Theatre Royal, 3I, 35; Vanbrugh's Relapse produced at, 134; Colley Cibber as manager of, 149 ; Christopher Rich as manager of, $\mathbf{1 6 9}^{-}$ I70, I72; annual performance of Rowe's Tamerlane at, I73; pantomimes at, $184-\mathbf{r} 86, \mathbf{r} 88$; Lillo's George Barnwell at, 207 ; Fielding's plays at, 213, 218; secession of actors from, 219 ; burlesque of a production at, 220 ; failure of Fielding's Eurydice at, 22 I; Garrick's Lethe at, 228 ; actors' dissensions at, 228; Garrick and Lacy as managers of, 229 ; stock plays at, 230; Shakespearean productions at, 231 n., 232-234; revivals of $M$ erope at, 237 ; Garrick at, 246; refunding of 'advanced money' at, 247, 247 n.; Garrick's term as manager of, 250; Kelly's False Delicacy produced at, 268; Sheridan as manager of, 30I, 312 ; Sheridan's plays produced at, $30 \mathrm{I}-$ 302, 308.

Dryden, John,

dramatic work and critical theories, 53-68, 88-95; his alteration (with D'Avenant) of The Tempest, 5, 32; his collaboration with Sir Robert Howard, I 10; as critic, 3, 4, $35,50,5 \mathrm{I}-52$; his attitude toward Shakespeare, $5,5 \mathrm{n} ., 35,177$; on the origin of 'heroic plays,' 23-24; his dramas as stock plays, 35,173 ;
Spanish influence on, 45, 109: his tribute to Wycherley's Plain Dealer, 82 ; his satire of Shadwell, 84,86 ; his attitude toward Jonson and Corneille, 84 ; as laureate, 86 ; his controversy with Howard, 105, III; his references to Dorset Gardens spectacles, I 7, II 7 n., I68, I69; to Southerne, I 8 , I $8 \mathrm{n}$; ; his praises of Congreve, 1 22, 130; his attitude in Collier controversy, I $21,145^{-}$ 146, r45 n., I46 n.; his definition of opera, I7 I ; other references to Dryden, 43, 71, 73 n., 77, 85, 86, 104, I 13, I 15, 148, I66, I70, I73, I79, I82, 216; BIBL., 323-324.

Duenna, The (Sheridan), 299-301, I94.

Duke of Guise, The (Dryden and Lee), 93.

Duke of Lerma, The (main title, The Great Favourite, Sir Robert Howard), I I I ; its Preface cited, 60.

Duncombe, William, adapts Voltaire's Brutus, 200; his verses on Hughes's Siege of Damascus, I96-I97.

D'Urfey, Thomas, Restoration dramatist, II 6.

Dutch Lover, The (Mrs. Behn), 109.

Earl of Essex, The (Jones), 239-240. Edgar (Rymer), 89, 89 n.

Edward and Eleonora (Thomson), I97.

Elfrid (Hill), $200 \mathrm{n}$.

Elfrida (Mason), 243.

Elizabethan drama, its height and decline, I-2; its methods of stage presentation, 3 ; its general contrasts with Restoration drama, 3-12; its influence on 'drolls,' r8-19; D'Avenant as follower of, 20-2I, 29, 32-33; T. Killigrew as follower of, 33 ; its anticipation of 'heroic drama,' 22-23; its vital connection with Restoration drama, 35, 43, 48; Restoration 
Elizabethan drama - Cont. revivals of, 35-36, 48; Spanish influence on, 45 ; use of rhymed couplet in, 54; Dryden's attitude toward, $63-64,68,95$; connection of its comedy with Restoration comedy, 72, 83-84, 86; Rymer's attacks on, 88-90; influence of, after All for Love, 95 ; on Otway, IOI, I02; Queen Anne performances of, $172-173,183$; its domestic tragedies in relation to Lillo, 202; Dodsley's Old Plays published, 238.

Elmerick (Lillo), 208.

Elvira (George Digby, Earl of Bristol), 45 .

Elvira (Mallet), 260.

Emperor of the Moon (Mrs. Behn), II, 184.

Empress of Morocco, The (Settle), II 3 , I $3 \mathrm{n}$.

English Merchant, The (Colman), 237.

Englishman in Paris, The (Foote), 251.

Englishman Relurned from Paris, The (Foote), 251.

Epilogues,

Restoration tragedies capped with coarse, 42, 166; Young's coarse, 196.

Epsom Wells (Shadwell), 84-85.

Essay of Dramatic Poesy, An, by Dryden, $60,60 \mathrm{n} ., 63 \mathrm{n}$.

Essay on Comedy, An, by George Meredith, cited, I3I n.; BIBL., 328.

Essay on the Theatre, An,

Goldsmith's views on sentimental comedy in, 266-267, 283; Dobson's reprint of, $266 \mathrm{n}$.; BIBL., 337.

Etherege, Sir George,

dramatic work, 73-77; his early use of rhyme, 55, 71, 111; his 'seven years' silence,' 78, $78 \mathrm{n}$.; Wycherley's possible debt to, 78; his fop, Sir Fopling Flutter, I1 2, 134, 150; other references to his comedies, $46,86,104,105$, 123, 132, 135; BIBL., 324.
Euripides,

Dennis's borrowing from, 167.

Eurydice (Fielding), 221.

Eurydice Hissed (Fielding), 22 1, 223.

Evelyn, John, his Diary cited, III n., 14 I.

Evening's Love, An (Dryden), 56-57, 45.

Fair Penilent, The (Rowe), 173-176; Garrick as Lothario in, 229; BIBL., 330.

Fall of Phaeton, The, burlesqued by Fielding, 220.

False Concord (Townley), 254; as a source of The Clandestine Marriage, $26 \mathrm{r}$.

False Delicacy (Kelly), 268-271, 277. 282, 310.

False Friend, The (Vanbrugh), 133.

Fanshawe, Sir Richard, his translations of Spanish drama, 46; his work parodied in The Rehearsal, 65 .

Farquhar, George, dramatic work, 136-140, 122, 141, 173, 209, 247 n.; his attitude toward Collier, 148; Garrick acts in his Recruiting Officer, 228, 229; compared with Goldsmith, 286, 286 n.; BIBL., 328-329.

Fashionable Lover, The (Cumberland), 274.

Fatal Curiosity (Lillo), 208;

Fielding's Prologue to, 217 ; Fielding's productions of, 220 ; BIBL., 332-333.

Fatal Discovery, The (Home), 240.

Fatal Discovery, The, or Love in Ruins (Anon.), 166.

Fatal Extravagance, The (Hill), $200 \mathrm{n}$. Fatal Marriage, The (Southerne), I1 $8,174$.

Fatal Vision, The (Hill), $200 \mathrm{n}$.

Fate of Capua, The (Southerne), 118.

Fathers, The, or The Good-Natured Man (Fielding), 223.

Fenton, Elijah, his Mariamne, 216.

Fenton, Lavinia, as Polly Peachum, 190. 
Field, Nathaniel, his Fatal Dowry (with Massinger), I74, 175 .

Fielding, Henry, dramatic work, 213-224; other references to his Tom Thumb, 194, I96, I97, 256; his Squire Western and Steele, I62; his own reference to Cato and The Conscious Lovers, 163; Gay as a forerunner of, 192 , I94; his appreciation of Lillo, 203, 206; an Epilogue by, 210; his relation to the Licensing Act, 22I-222; turns from drama to novel, 225-226; satirizes Cibber's Shakespearean alterations, 23I-232; his relation to dramatic afterpieces, 248; Foote as a follower of, 250; Murphy's debt to his farces, 255, 256; Colman's dramatization of Tom Jones, 258-260; his hits at sentimental drama, 265 ; Sheridan's Critic indebted to, 3II; BIBL., 333.

Filmer, Edward, in Collier controversy, 144.

First Days Entertainment at RutlandHouse (D'Avenant), 22.

Fitzpatrick, Richard,

his Prologue to Sheridan's Critic, 308, $308 \mathrm{n}$.

Flecknoe, Richard,

his Love's Dominion, ro7; his Short Discourse of the English Stage, 40 ; BIBL., 322.

Fletcher, John, (see also Beaumont and Fletcher) D'Avenant's adaptation of The Two Noble Kinsmen, 32 ; his possible influence on $T$. Killigrew, 33; Lamb's reference to, 37; his debt to Cervantes, 45; Dryden's references to, 60, 93; Rymer's attack on, 89; his Bonduca, 93 ; his relation to Crowne's Married Beau, II2; Tate's adaptation of, I15; Vanbrugh's adaptation of, 133; Farquhar's debt to, 137; Collier's tolerance towards, I42; Cibber's debt to, I50; revival of his Humorous Lieutenant, 183 ; BIBL., 323 (under J. W. Tupper). Florizel and Perdita (Garrick), 233. Foote, Samuel, dramatic work, 249-254; as a follower of Fielding, 224; attacks Voltaire, 236, $236 \mathrm{n}$.; satirized in The Spouter, 255; transfers Haymarket Theatre, 262; presents She Stoops to Conquer, 283; his burlesque of sentimental drama, 283-284; Sheridan's debt to, in The Critic, 3II ; BIBL., 336.

Footman, The, an anonymous opera, $217 \mathrm{n}$.

Forc'd Marriage, The (Mrs. Behn), II 4 .

Forster, John,

his Life of Goldswith cited, 285 n.; BIBL., 338.

Foundling, The (Moore), 2 Io.

French drama, general influence of, on Restoration drama, 47-51; on 'heroic drama,' 57-59; on minor Restoration drama, Iro; on Queen Anne drama, I79, I83-184; on subsequent eighteenth-century drama, 235-237.

French heroic romances, influence of, on English 'heroic drama,' 57-58, 62, 109.

Friendship in Fashion (Otway), 100.

Funeral, The (Steele), 156-158, 151; its Prologue cited, I68-I69.

Gamester, The (Moore), 210-212, 239, 243.

Gamesters, The,

Garrick's alteration of Shirley, 238. Garrick, David, as actor and playwright, 227-234; his Country Girl, 80, 300; his Isabella, II8; his Gamesters, 238; his farces, 254; his Clandestine Marriage (with Colman), 26I262; his relation to Moore's plays, 212; his attitude towards Home's plays, 240, 242-243; his concessions to popular taste, 246 , 248; Foote's attitude towards, 249, 
Garrick, David - Cont. 250; his connection with Kelly's False Delicacy, 268, 277; incidental references to his acting, 178, 201, 222, 236, 245, 260; BIBL., 334-335.

Gay, John, dramatic work, 189-194; other references to The Beggar's Opera, 140, 204, 213, 214, 246, 299; burlesques sentimental drama, 265 ; BIBL., 331-332.

Genest, John,

author of Some Account of the English Stage, cited, 39, 137 n., 167, 174 n., 176,176 n., 179 n., 188 n., 189 n., 209, 217 n., 219 n., 222 n., 223 n., 230, 231 n., 234 n., 236 n., 240 n., 247 n., 248,249 n., 277 n., 278 n., 284 n.; BIBL., 316.

Gentleman Dancing-Master, (Wycherley), 79, 77;

Bickerstaff's debt to, 257.

George Barnwell, The History of (main title, The London Merchant, Lillo), 202-207, 209; BIBL., 332-333.

Gil Blas (Moore), 210.

Gildon, Charles, dramatic work, 167 ; in Collier controversy, 144; his Comparison between the Two Stages cited, $169 \mathrm{n}$.

Gloriana (Lee), 96.

Golden Rump, The, as a stimulus to the Licensing Act, 221.

Goldsmith, Oliver, dramatic work, 277-290; other references to The Good-Natur'd Man, 125, 268; to She Sloops to Conquer, 76, 126 (Tony Lumpkin in), 130 (Diggory in), 135, 139, 140, 162; comic spirit not extinct before, 261-262, 263 ; Colman's productions of his plays, 262 , $262 \mathrm{n}$.; his attacks on sentimental comedy, 265-268; incidental comparisons with Sheridan, 201, 297 ; BIBL., 337-338.

Goodman's Fields Theatre, Giffard as manager of, 221 ; Garrick's triumph at, 228.
Good-Natur'd Man, The (Goldsmith), 277-282;

a predecessor of Young Honeywood in, 125; Colman's production of, 262,262 n.; clashes with Kelly's False Delicacy, 268; compared with She Stoops to Conquer, 287-289; BIBL., 337-338.

Gorboduc (Sackville and Norton), cited by Dryden, 54; 'dumbshows' in, 184.

Gosse, Edmund W. his Seventeenth-Century Shudies cited, 74 n., 99, 99 n., 106 n.; BIBL., 324, 326, 327; his distinction between'Restoration' and 'Orange' dramatists, 106-107, $106 \mathrm{n}$.; his Congreve cited, 122 n., 126 n., 128 , 128 n., I44 n., BIBL., 327-328.

Granville, George (Lord Lansdowne), his Heroick Love, 166, 167; his version of The Merchant of Venice, 232. Grave-Makers, a 'droll,' 18.

Gray, Thomas,

his opinion of Douglas, 241, 241 n.; his connection with Mason, 243, 244.

Greal Favourite, The, or The Duke of Lerma (Sir Robert Howard), III ; its Preface cited, 60.

Grecian Daughter, The (Murphy), 256.

Grounds of Criticism in Tragedy, The, Dryden's essay on, 93.

Grub-Street Opera, The (Fielding), 217.

Grumbler, The (Sedley), III n.

Guardian, The (Cowley), revised as Cutter of Coleman-Street, 37.

Guarini, English translations of his Pastor Fido, 107-108, $108 \mathrm{n}$.

Guzman (Orrery), 45, $45 \mathrm{n}$.

Gwynn, Eleanor (Nell), actress, 56 .

Halhed, Nathaniel B., collaborates with Sheridan, 292.

Hamilton, Anthony, his Memoirs of Count Grammont, I0-1X, 75; BIBL., 320. 


\section{Hamlet,}

Grave-Makers, a 'droll' based on, I8; Congreve's Love for Love in relation to, I25, I $25 \mathrm{n}$.; Jeremy Collier's comment on Ophelia, I42 ; Voltaire's borrowings from, I99; Garrick as the Ghost in, 229; Betterton as, 233; Garrick's production of, 233 .

Handel, George Frederick, his English operas, 172, 181, 200, 231 ; oratorios, 97 n., 231.

Handsome Housemaid, The, or Piety in Pattens,

Foote's burlesque, 284 .

Hardy, Alexandre,

his French tragi-comedies, 49.

Harlequin Dr. Faustus,

Thurmond's pantomime, 188 .

\section{Harlequin Sorcerer,}

Rich's pantomime, I89.

Hatchett, William,

his Rival Father, 235.

Hawkesworth, John,

his alteration of Oroonoko, I 18 .

Haymarket, Little Theatre in the,

its early history, 218-219; Fielding's connection with, 219-220, 222 ; Foote's performances at, 249.

Haymarket Theatre,

its opening performances, $132,172$.

Hazlitt, William,

his eulogies of Congreve, r30, I $30 \mathrm{n}$., r31-r32; his comment on Vanbrugh's Lord Foppington, I34, I34 n.; BIBL., 329.

Hazlitt, W. Carew,

documents in his English Drama and Stage cited, $\mathrm{I}_{4} \mathrm{n}$., I 5 n. ; BIBL., $32 \mathrm{I}$.

Hells Higher Court of Justice (pr. I66r), an attack on Cromwell, 37 .

Henley, W. E., his edition of Fielding cited, $214 \mathrm{n}$.; BIBL., 333.

Henry IV, Part I (Shakespeare), revivals of, 183, 232; The Bouncing Knight, a 'droll' based on, 18.

Henry IV, Part II (Shakespeare), revivals of, 23I, 232.
Henry $V$ (Shakespeare),

revival of, 23 I.

Henry the Fifth, King (Hill), $200 \mathrm{n}$.

Henry the Fifth, The History of (Orrery), 54 .

Henry VI, Part I (Shakespeare), revival of, $23 I$.

Herbert, Sir Henry, his 'Office-book' cited, 2, 2 n.; protests against the patentees, $3 \mathrm{I}$.

Heroic Daughter, The, or Ximena (Cibber), 183 .

'Heroic drama,'

D'Avenant's Siege of Rhodes as a possible example of, 23-25; his later operas in relation to, 27-28; introduction and development of rhymed, 54-70; partial survival of, I66-167; BIBL., 323-324.

Heroick Love (George Granville), 166, I67.

Heroic Plays, An Essay of, by Dryden, $66,23-24,24$ n., 62 n.

Heywood, Thomas, as a forerunner of domestic tragedy, 202.

High Life, Below Stairs (Townley), 254-255, 2 I 7, $217 \mathrm{n}$.

Hill, Aaron, adapts Voltaire's plays, 200, 20I ; his libretto to Rinaldo, 200; his comment on Voltaire, 235.

Hill, Abraham, his notice of Wilson's Cheats, 39, $39 \mathrm{n}$.

Hill, G. B.,

his edition of Dr. Johnson's Lives of the English Poets cited, $63 \mathrm{n}$. and passim; his edition of Boswell's Life of Johnson cited, $127 \mathrm{n}$. and passim.

Historia Histrionica, by James Wright, cited, I5, I9 n.; BIBL., 319.

Historical Register for I736, The (Fielding), 220-22I; its hits at Cibber's alteration of Shakespeare, 231-232.

History of the Mimes and Pantomimes, The, by John Weaver, cited, 185 n., 186, 186 n. 
Hoadley, Benjamin, his Suspicious Husband, 245.

Hogarth, William, his work compared with Lillo's, 203; its connection with The Clandestine Marriage, 261.

Home, John, dramatic work, 240-243, 239; Douglas parodied, 309, 309 n.; BIBL., 335-336.

Hoole, John, his Cyrus, 237.

Howard, Edward, minor Restoration dramatist, 116 .

Howard, James, minor Restoration dramatist, 116.

Howard, Sir Robert, dramatic work, II0-III; his Indian Queen (with Dryden), 55, 55 n., 58; his controversy with Dryden over rhymed drama, 60; his own practice, I05; attacked in The Rehearsal, 64, $64 \mathrm{n}$.

Hughes, John, dramatic work, 196-197.

Hume, David, his opinion of Dougles, 241.

Humorists, The (Shadwell), 84.

'Humour comedy,' (see also Jonson, Ben) Wilson's revival of, 38-40; Congreve's definitions and views of 'humour' and 'wit' in comedy, 129-130; 'humours' in Sheridan's Rivals, 298.

Hunt, Leigh, his edition of The Dramatic Works of Wycherley, Vanbrugh, Congreve, and Farquhar, 8 n., 76, 106 ; BIBL., 324-325, 328-329.

Burlothrumbo (Samuel Johnson, of Cheshire), 214, 219.

Hy pocrile, The (Bickerstaff), $152,257$.

Ibrahim (Settle), II3.

Inconstant, The (Farquhar), 137.

Indian Emperor, The (Dryden), 55-56, 58.

Indian Queen, The (Sir Robert Howard and Dryden), 55, 55 n., 58, IIO.
Innocens Adultery, The (main title, The Fatal Marriage, Southerne), I18.

Interregnum (1642-1660), interrupts rather than breaks continuous course of drama, $1-2$; condition of drama and stage during, 14-29.

Intriguing Chambermaid, The (Fielding), 217 .

Invader of his Country, The, Dennis's version of Coriolenus, 230, $230 \mathrm{n}$.

Iphigenia (Dennis), 167.

Irene (Dr. Samuel Johnson), 238239; BIBL., 335.

Irish Widow, The (Garrick), 254.

Irving, Sir Henry, his opinion of Sheridan, 313 .

Isabella, or The Fatal Marriage, Garrick's version of Southerne's Fatal Marriage, 118.

Island Queens, The (Banks), II 7.

Jackson, John, his History of the Scoltish Slage cited, 188, $188 \mathrm{n}$.; BIBL., 331, 336.

Jane Shore (Rowe), I77-178, 183, 202 ; BIBL., 330.

Jealows Wife, The (Colman), 258$260,245,262,263$.

Jefferson, Joseph,

his version of Sheridan's Rivals, 297, $297 \mathrm{n}$.

Jew, The (Cumberland), 274.

Johnson, Charles, dramatic work, 209-2ro.

Johnson, Dr. Samuel, his Ireme, 238-239; his opinion of Dryden's Conquest of Granada, 63 ; of Congreve's Mourning Bride, 127; of Rowe's Fair Penilent, 174; of Addison's Cato, 18r ; of Home's Douglas, 241 ; of Goldsmith's She Stoops to Conquer, 284, 286, 289; his connection with Garrick, 228, 239; with Goldsmith, 283; his remarks on Foote, 250, 25I; his praise of Mrs. Frances Sheridan, 292; BIBL., 335. 
Johnson, Samuel (of Cheshire), his Hurlothrumbo, 214, 219.

Jones, Henry, his Earl of Essex, 239-240.

Jonson, Ben.,

Restoration revivals of his plays, $35-36,38,48$; his influence on Wilson, 38-39, 43, 72, 83; on Dryden, 63,84 ; on Shadwell, 84 ; his attitude toward classical drama, 49; Dryden's reference to, 60; as a forerunner of Restoration comedy, 72, 86; Jonsonian characters in Wycherley, 78; in Congreve, 123, 126; Sedley's reference to his tragedies, III; Queen Anne revivals of his plays, 183 ; Colman's version of his Silent Woman, 262; Sheridan's 'humours' in The Rivals, 298.

Journey to Bath, $A$, Mrs. Sheridan's unfinished comedy, 292.

Journey to London, A (Vanbrugh), 133, 152, 195.

Juliana (Crowne), II 2.

Julius Casar,

Voltaire's borrowings from, 199.

Jupiter, farce written by Halhed and Sheridan, 292, 3 I I.

Justice Caught in his own Trap, The (main title, Rape upon Rape, Fielding), 214, $214 \mathrm{n}$.

Kean, Edmund, actor, 178 .

Kelly, Hugh, dramatic work, 268-272, 156, $274,277,279,282$; his creed satirized by Sheridan, 3 ro; BIBL., 337.

Kemble, Charles, actor, I 78, 207.

Ker, W. P., his edition of Dryden's Essays cited, 24 n. and passim; BIBL., 323.

Killigrew, Thomas,

dramatic work, 33-34; his royal patent, 30-3I; his company
(King's) of actors, $3 \mathrm{I}$; his debt to Calderon, 45 ; BIBL., 322.

King Ahasuerus and Queen Esther, a 'droll,' 18.

King Arthur,

opera by Dryden, 94 .

King John (Shakespeare), 23r, 23 I n.;

Cibber's version of, 231-232, $23 \mathrm{In}$.

King's, The, company of actors, $3 I$.

Kirkman, Francis,

on the 'drolls', r6; his Wits, or Sport upon Sport, 16-19; BIBL., 321.

Knight, Joseph,

his edition of Roscius Anglicanus cited, I n.; BIBL., 319.

Knights, The (Foote), 249-250.

Kotzebue,

Sheridan's adaptations of, 302, 312.

La Calprenède, his influence on Restoration drama, 57, 96, 109.

La Chaussée, Nivelle de, his connection with sentimental drama, 264.

Lacy, John, dramatic work, I13; BIBL., 327.

Lady Jane Gray (Rowe), I77.

Lady's Last Stake, The (Cibber), $15 x$. La Fayette, Madame de, her influence on Lee, 98.

Lamb, Charles, his essay On the Artificial Comedy of the Last Century, 7-10; BIBL., 320 ; his opinion of Cowley's comedy, 37, 37 n.; of Lillo, 203, $203 \mathrm{n}$.

Lancashire Witches, The (Shadwell), 86; BIBL., 325.

Lansdowne, Lord (George Granville), his Heroick Love, 166, 167; his version of The Merchant of Venice, 232.

Law, William, his treatise against the stage, I47. 
Lew against Lovers, The (D'Avenant), 32.

Lear, King,

Tate's alteration of, 5, 115; Voltaire's borrowings from, 199; Garrick acts in, 229, 234; rival productions of, 234; Colman's version of, 262 .

Lee, John, his failure as Sir Lucius O'Trigger, 293, 294, 299.

Lee, Nathaniel,

dramatic work, 95-99; collaborates with Dryden, 92-93; satirized by Fielding, 216; incidental references to, $104,117 \mathrm{n}$., I73; BIBL., 326.

Lessing,

Lillo's influence on, 207, $207 \mathrm{n}$.

Lethe (Garrick), 228, 229.

Letter Writers, The (Fielding), 218.

Lewes, Charles Lee,

his Memoirs cited, 204, $204 \mathrm{n}$.

Licensing Act of 1737 .

its causes and effect, 22I-222; evaded by Foote, 249-250; BIBL., 334.

Lillo, George,

dramatic work, 202-209; his prose compared with Edward Moore's, 212 ; Fielding's connection with his Falal Curiosity, 217 , 220; his historical background, 224; BIBL., 332-333.

Limberham (Dryden), 92.

Lincoln's Inn Fields Theatre,

Duke of York's company at, 3I ; Downes, prompter at, 35; Betterton as manager of, 169; Rich's pantomimes at, 188-189; The Beggar's Opera at, 189-190; contrasted with the Little Theatre in the Haymarket, 218.

Linley, Thomas, his music for Sheridan's Duenna, 300.

Lionel and Clarissa (Bickerstaff), 257.

Locke, Matthew, his operatic work, 44, 94.

London Cuckolds (Ravenscroft),
London Merchans, The, of The $B$ istory of George Barmwell (Lillo), 202-207, 200; BIBL., 332-333.

Lottery, The (Fielding), $217,217 \mathrm{n}$.

Lounsbury, Thomas R., his Shakespeare and Vollaire cited, I 98 n., 199 n., 200 n., 235 n., 236 n.; BIBL., 332.

Love and a Bottle (Farquhar), 137, 137 n., 139.

Love and Honour (D'Avenant), 23 n., 32.

Love for Love (Congreve), 125-126; its Prologue cited, $82-83$; compared with Colman's Jealows Wife, 259, $259 \mathrm{n}$.

Love in a Village (Bickerstaff), 257.

Love in a Wood (Wycherley), 78-79, 77.

Love in Several Masques (Fielding), 213-214.

Love makes a Man (Cibber), Garrick acts in, 229.

Love's Dominion (pr. 1654, Flecknoe), 107 ;

altered as Love's Kingdom (pr. 1664), 40 n.; Discourse appended to the latter cited, 40; BIBL., 322.

Love's Last Shift (Cibber), 133-134, 149-150.

Loves of Mars and Venus, The (Weaver), 184-186.

Love Triumphant (Dryden), 93-94.

Lowe, Robert W.,

his edition of Colley Cibber's $A$ pology cited, $97 \mathrm{n}$. and passim; BIBL., 329 ; his edition of Doran's Annals cited, I95 n.; BIBL., 318; his Bibliographical Account of English Theatrical Literature, BIBL., 317.

Loyal Brother, The (Southerne), 118.

Lucius Junius Brutus (Lee), 98; Voltaire's alleged debt to, 200.

Lulli, composer of French operas, 44.

Lying Lover, The (Steele), 158-161, 151, 174, 192.

Lying Valet, The (Garrick), 229, 254. 
Macaulay, Thomas B., his essay on Comic Dramatists of the Restoration, 8-10 ; BIBL., 320; his remark on bear-baiting, I9; his opinion of Rymer, 89; of Collier, 146 .

Macbeth,

D'Avenant's alteration of, 5-6, 32, 4I ; Voltaire's borrowings from, I 99.

Macklin, Charles,

actor, $210,230,232,234$; his relations with Garrick, 228; his production of The Merchant of Venice, 232.

Macready, William C., actor, 178.

Mahomet the Imposter, James Miller's adaptation of Voltaire, 200, 200 n.; its Prologue cited, 200-20I ; Garrick acts in, 236.

Maid of Bath, The (Foote), 252-253, $25 \mathrm{I}$.

Maid of the Mill, The (Bickerstaff), 257.

Mallet, David, dramatic work, 197, 260.

Malone, Edmond, his edition of Shakspeare cited, $2 \mathrm{n}$.; BIBL., 322 ; his edition of Spence's Anecdotes cited, $76 \mathrm{n}$. and passim.

Manley, Mrs., dramatic work, 167.

Man of Mode, The, or Sir Fopling Flutter (Etherege), 75-76, 78 n., 123;

other references to his fop, Sir Fopling Flutter, 112, 134, 150.

Man of Reason, The (Kelly), 272.

Man's the Master, The (D'Avenant), 32-33.

Marforio, produced by John Rich, 220.

Mariamne (Fenton), 216.

Marina (Lillo), 208.

Marivaux, a forerunner of sentimental drama, 264.

Marks, Jeannette, her English Pastoral Drama cited, 107 n.; BIBL., 326.

Marlowe, Christopher, 'heroic' elements in his Tamburlaine, 22, 62; comic scenes in his Dr. Faustus, 102.

Marplot in Lisbon (Mrs. Centlivre), I54.

Marriage-d-la-Mode (Dryden), 67.

Married Beau, The (Crowne), II2.

Mason, William, dramatic work, 243-244.

Masque, English, its introduction of operatic elements, 22; of scenery and costume, 25; D'Avenant's connection with, 44 ; a somewhat late survival of, 208.

Masque of Alfred (Thomson and Mallet), 197.

Massacre of Paris, The (Lee), 98.

Massinger, Philip, as a forerunner of 'heroic drama,' 22 ; Rowe's debt to, 174, 175.

Mayor of Garratt, The (Foote), 253.

Measure for Measure, as a partial source of D'Avenant's Law against Lovers, 32.

Memoirs of Count Grammont, by Hamilton, 10-11, 75; BIBL., 320.

Mendoza, Antonio de, Fanshawe's translations of, 46.

Merchant of Venice, The, Macklin's production of, 232; Lord Lansdowne's version of, 232.

Meredith, George, his opinion of Congreve's Millamant, I30-131 ; BIBL., 328 (Essay on Comedy).

Meriton, George, a forerunner of Jeremy Collier, I 20-I 2 I.

Merope (Hill), 200; its Advertisement cited, 235 ; Garrick acts in, 236; revivals of, 237.

Merry Wives of Windsor, The, popularity of, during Restoration, 36,232 ; Dennis's version of, 230 , $230 \mathrm{n}$.

Middleton, Thomas, as a forerunner of Restoration comedy, 72; his influence on Mrs. Behn, II4. 
Midsummer Night's Dream, A, Pepys's opinion of, 6 ; Bottom the Weaver, a 'droll' based on, 16; Garrick's version of, in The Fairies, 248.

Miller, James, adapts Voltaire's Mahomet, 200201, $200 \mathrm{n}$.

Milton, John,

Dryden's operatic version of Paradise Lost, 67 ; his blank verse, 92, 128; non-dramatic character of his Samson Agonistes, $92 \mathrm{n}$.

Minor, The (Foote), 251-252.

Miser, The (Fielding), 218.

Miser, The,

Shadwell's adaptation of $L$ 'Avare, 84.

Miss in her Teens (Garrick), 254.

Miss Lucy in Town (Fielding), 222.

Mistake, The (Vanbrugh), 133.

Mithridates (Lee), 97-98.

Mock Doctor, The (Fielding), 218.

Modern Husband, The (Fielding), 218.

Molière,

general influence of, on Restoration drama, 50-51, 47, 83, 110; influences D'Avenant, 32 ; Dryden, $56,57,93$; Etherege, 74 ; Wycherley, 78, 78 n., 79, 80-82, 81 n., 1 27 , 140; Shadwell, 84; Otway, 100; Sedley, I11; Ravenscroft, I1 2 ; Mrs. Behn, I14; Congreve, 124; Vanbrugh, 133; Cibber, I51; Mrs. Centlivre, 154; Steele, 162 ; Fielding, 21 8; Murphy, 255, 256; Sheridan, 299, 306; as librettist, 44.

Moncrief, John, his Appius, 240.

Moore, Edward, dramatic work, 210-212, 239, 243 ; BIBL., 333.

Moore, Thomas, on The Duenne, 300; his Life of Sheridan, 304; BIBL., 340.

Morell, Thomas, his 'See the conquering hero comes,' $97 \mathrm{n}$.

Moreto, A.,

his influence on St. Serfe, 46 n.; on Crowne, 46 n., rog.
Motteux, Peter Anthony, his Beauly in Distress, 166-167: his Arsinoë, 171.

Mourming Bride, The (Congreve), 126-128;

Blackmore's praise of, $120 \mathrm{n}$.

Muck Ado about Nothing, as a partial source of D'Avenant's Law against Lovers, 32.

Mulberry Garden, The (Sedley), 78, III.

Murphy, Arthur, dramatic work, 255-256; versions of Voltaire, 235-236, 237 ; BIBL., 336.

Musical Lady, The (Colman), 260.

Mustapha (Orrery), 54 .

Necromancer, The, or The History of Dr. Faustus,

Rich's pantomime, 188 .

Nero (Lee), 96.

Nettleton, George H., his Major Dramas of Sheridan cited, 162 n., 242 n., 293 n., 297 n.; BIBL., 315, 340; his chapter in Cambridge History of English Liverature cited, 207 n.; BIBL., 315.

Newcastle, Duchess of, minor dramatist, I I 5-1 16.

Newcastle, Duke of, minor dramatist, 84, $115-116$.

Nicholson, Watson, his Struggle for a Free Stage in London cited, 192 n.; BIBL., 334.

Non-Juror, The (Cibber), 151-152, 195, 257.

No One's Enemy but His Own (Murphy), 237.

Novel, English, rise of, in relation to the decline of drama, 225-226 ; sentimental tendency in, 264.

CEdipus (Lee and Dryden), 92-93, 99. Old Bachelor, The (Congreve), 122123, 132; Macaulay on its immorality, 8-9; Garrick acts in 229.

Oldfield, Anne (Nance), actress, $137,197$. 
Old Man Taught Wisdom, An (Fielding), 217.

Old Troop, The (Lacy), II3.

Opera, English,

D'Avenant's Siege of Rhodes as, 2 I$22,24-25,43$; other references to his operatic work, $5-6,27,30,33$; early spectacular operas, 4I, II 7 , 170; influence of French opera on Restoration opera, 43-44; Dryden's operas, 94 ; his definition of, I7I; Italian operas on English stage, $170-172,185$; satirized, 192 , 213; Addison's English opera, 172 , 172 n.; Handel's operas, 172 ; ballad opera (Gay's Beggar's Opera), 189-194, 213; Carey's operas, 216, 217; Garrick's operatic versions, 234, 248; Bickerstaff's operas, 257; Sheridan's Duenna, 299-301.

Opera, French,

its influence on Restoration opera, 43-44, 94.

Opera, Italian,

its introduction into France, 43; into England, 170-172; satirized by Gay, 192, 213.

Orators, The (Foote), $25 \mathrm{I}$.

Orestes,

Francklin's adaptation of Voltaire's Oreste, 236.

Oroonoko (Southerne), II 8 ;

altered by Hawkesworth, I18; Garrick acts in, 229.

Orphan, The (Otway), 100-101, I74. 202;

Garrick's appearance in, 229; BIBL., 326.

Orphan of China, The (Murphy), 235236, 237.

Orpheus and Eurydice, John Rich's pantomime, 246.

Orrery, Earl of (Roger Boyle), dramatic work, 54-55, 55 n.; his Guzman, 45, 45 n.; his Black Prince, 59; his debt to French romances, 109; BIBL., 323.

Othello,

Pepys's opinion of, 6, 45; Rymer's opinion of, 89; Young's debt to
Iago, 196; Voltaire's borrowings from, 199 .

Otway, Thomas, dramatic work, 99-103, 92, 95-96; as a forerunner of sentimental drama, II9, I55, I60, 264, 265; Rowe's relations to, $173, \mathbf{1 7 8}$; his Orphan as a domestic tragedy, $\mathbf{1 7 4}$, 202; Garrick's debt to his Caius Marius, 233; various references to, 104, 106, 229, 238, 24I ; BIBL., 326. Oulton, Walley C.,

on the 'immoral tendency' of Gay's Beggar's Opera, 193, I93 n.; on Foote's Handsome Housemaid, 284, $284 \mathrm{n}$.; his History of the Theatres of London, BIBL., 338.

Padlock, The (Bickerstaff), 257.

Pantomime, English, its rise and importance, 184-189, 246-247.

Papal Tyranny in the Reign of King John (Cibber), 23r, 23I n.

Paradise Lost, Dryden's operatic printed version of, 67.

Parson's Wedding, The (Thomas Killigrew), revival of, 34 ;

its debt to Calderon, 45.

Pasquin (Fielding), 219-220, 218, 221.

Pastorals, during the Restoration, 107-109.

Patent Theatres, (see Drury Lane, Covent Garden, etc.)

established under Charles II, I-2, 3I; Cibber's account of, II 7 ; rival pantomimes at, 188; Foote's patent virtually establishing third Patent Theatre, 250.

Patron, The (Foote), 253.

Pepys, Samuel,

his Diary, ro; his opinions of Shakespearean plays, 6,45 ; his testimony as to Thomas Killigrew, 34 ; as to Restoration plays and performances, $38,45 \mathrm{n}$., $54,55 \mathrm{n}$., 73, III n.; other references to, 74 , I4I ; BIBL., 320.

Pericles, Prince of Tyre, Lillo's Marina based on, 208. 
Perrin, Pierre,

French opera of, 44.

Phadra and Hippolytus (Edmund Smith), 179.

Philaster (Beaumont and Fletcher), revival of, 183 ;

Colman's alteration of, 260 .

Philips, Ambrose,

dramatic work, 179, 183, 184, 235, 239; satirized by Fielding, 216.

Philips, Mrs. Catherine, the 'matchless Orinda,' I10; BIBL., 327.

Pilgrim, The (Vanbrugh), 133.

Pix, Mrs.,

dramatic work, 167.

Pizarro (Sheridan), 302, 312.

Plain Dealer, The (Wycherley), 80$83,77,123$.

Plautus,

Dryden's following of, 93; Fielding's debt to, 218 .

Playhouse to be Let, The (D'Avenant), 32.

Polly (Gay), 193-194, 222.

Polly Honeycombe (Colman), 258.

Pope, Alexander, on the chronology of Wycherley's plays, 77 ; on Cato, 180, 181; on pantomime (in The Dunciad), 187188; note in The Dunciad, 189 n.; collaborates with Gay, 190; his connection with The Beggar's Opera, 190-191; his opinion of Hughes, 196; of Lillo's George Barmwell, 206; hits at card playing, 210; as editor of Shakespeare, 23I; hits at Cibber's King John, $23 \mathrm{I}$.

Powell, William,

as actor, 260, 277 ; as manager, 262.

Present State of Polite Learning, The, Goldsmith essay on, 265-266, 265 n., 268, 277.

Princess of Cleve, The (Lee), 98.

Projectors, The (Wilson), 38-39.

Provoked Husband, The (Cibber), 133, 152, 195, 214, 303.

Provok'd Wife, The (Vanbrugh), 135, 133, 136.
Prynne, William, author of Histrio-Mastix, 14, 121, 142, 143.

Psyche (Shadwell, music by Matthew Locke), 41, 44, 85, 117, 170.

Puppet-plays, during dramatic interregnum, 16.

Purcell, Henry, his operas, 44, 94.

Puritans,

hostility of, towards theatres, I, 14; Macaulay's dictum on, 19; depicted in early Restoration plays, 36-37.

Quarles, Francis,

his Virgin Widow published during interregnum, 19, 54; privately acted, 55 ; its early use of 'heroic couplet,' 54-55, 59; parodied in The Rehearsal, 55, 55 n., 65.

Queen Anne drama, aspects of, 166-184.

Queen Catharine (Mrs. Pix), 167.

Queen Mab,

Garrick's 'entertainment,' 246.

Quin, James, his comment on Garrick's acting, 228.

Quinault, Philippe,

French operatic libretti of, 44; Dryden's borrowings from, 56 .

Racine, Jean, general influence of, on Restoration drama, 110, 35, 47 ; influences Wycherley, 81-82; Lee, 97-98; Otway, 100; Crowne, 112; eighteenth-century versions of, 179 , 183, 198, 235, 239 ; BIBL., 331, 335.

Rae, W. Fraser,

his Life of Sheridan cited, $313 \mathrm{n}$.; BIBL., 340; his edition of Sheridan's Plays, BIBL., 339.

Rape upon Rape (Fielding), $214,214 \mathrm{n}$. Rapin, Rymer's Preface to his Reflections, 88.

Ravenscroft, Edward, dramatic work, III-112, I10; his friendship with Mrs. Behn, 124. 
Recruiting Officer, The (Farquhar), I37, 247 n.;

Garrick's appearances in, 228, 229.

Red Bull Theatre, actors assembled at, $3 \mathbf{I}$.

Rehearsal, The (Villiers and others), 64-66;

its parody of Quarles, 55, $55 \mathrm{n}$.; its Prologue cited, 86; Rymer's opinion of, 89 ; its influence on Gay, 190; on Fielding, 213, 214 , 2I6; on Sheridan, 292, 308, $31 \mathrm{I}$; Garrick as Bayes in, 229, 229 n.; Foote as Bayes in, 249; Arber's reprint of, 55 n., 308; BIBL., 324.

Relapse, The (Vanbrugh), 133-134, 135, I39;

Sheridan's adaptation of, I35, 30I302 ; Collier's attack on, I43; Cibber's comment on, 149 .

Restoration drama,

definitions of, 106-107; its stage methods contrasted with Elizabethan, 3, 40-42; its general contrasts with Elizabethan drama, 3-12; its vital connection with Elizabethan drama, 35, 43, 48; Spanish influences on, 44-47; French influences on, 47-51, IIo; some general aspects of, 71-72; aspects of minor, ro4-119; reaction against immorality of, I20-12I, I4I-148; Cibber's Careless Husband as an expurgated Restoration comedy, I50; The School for Scandal in relation to, 306.

Revenge, The (Young), 195, 196.

Reynolds, Sir Joshua, 133, 229.

Rhodes, John,

his license for acting, 30-3I.

Rich, Christopher,

as manager at Dorset Gardens, I68; at Drury Lane, 169-1 70, I72.

Rich, John,

his pantomimes, 184-189, 246; his productions of Gay's Beggar's Opera, 189, 246; his connection with Fielding, 220; his Shakespearean revivals, 23I; his production of Home's Douglas, 240; BIBL., 33I.
Richard II, revival of, 23I ; Tate's adaptation of, II5.

Richard $I I I$, its relation to Rowe's Jane Shore, 177, I78; Cibber's alteration of, I50, 230; Garrick's appearance in, 228 .

Richardson, Samuel, as novelist, 155, 176, 206; Pamela, advent of, 225; Dance's dramatization of, 229; Bickerstaff's debt to, 257; La Chaussée's Pamela, 264.

Rinaldo,

Handel's opera, I72, I8I; Hill's libretto to, 200 .

Rinaldo and Armida (Dennis), 167. Rival Father, The (Hatchett), 235.

Rival-Ladies, The (Dryden), 45, 54, 55, 55 n., 73 n.;

its Prologue cited, 53, 53 n.; its Dedication cited, $60,60 \mathrm{n}$.

Rival Queens, The (Lee), 96-97, 97 n., I $7 \mathrm{n}$.

Rivals, The (Sheridan), 293-299, 279, 282, 301, 304, 306, 307, 313; Mrs. Malaprop in, 124; servants in, 125, 287; Lydia Languish and Steele's Biddy Tipkin, I62, I62 n.; compared with Colman's Polly Honeycombe, 258 ; Sir Lucius O'Trigger and Cumberland's Major O'Flaherty, 273, 273 n.; BIBL., 339-340.

Rochester, Earl of (John Wilmot), his reference to Etherege, $78,78 \mathrm{n}$.; his estimate of Shadwell's work, 86 . Roman Father, The (Whitehead), 239. Romeo and Juliet,

Otway's version of, in Caius Marius, 100, 233; Otway's diction compared with, ror n; Garrick's production of, 233.

Romp, The (Bickerstaff), $257 \mathrm{n}$.

Rosamond, Addison's opera, 172, 172 n., 180. Roscius Anglicanus, by John Downes, its testimony cited, 5-6, 6 n., 3536, 35 n., 38, 39, 4I, 4I n., 45, 45 n., I69, I69 n.; BIBL., 319; 
Roscius Anglicanus - Cons.

Knight's reprint of, cited, I n.; BIBL., 319.

Ross, David, acts in George Barnwell, 204.

Rotrou, Jean, his French tragi-comedies, 49.

Roundheads, The (Mrs. Behn), I14. Rover, The (Mrs. Behn), Iog, 114. Rowe, Nicholas, dramatic work, 173-179, 184, 202, 238, 246; Epilogue to his Ambitious Step-Mother cited, 169; its Prologue cited, 177; as editor of Shakespeare, 177, 215, 230; Garrick acts in his Fair Penilent, 229; BIBL., 330.

Rowley, William, as a forerunner of Restoration comedy, 72; The Thracion Wonder ascribed to, $107,108$.

Royal Convert, The (Rowe), 176.

Royal Shepherdess, The (Shadwell), 108.

Rump, The (Tatham), 36.

Rymer, Thomas, his attacks on Elizabethan drama, 88-90, 142; Dryden's attitude towards, 88, 90, 93 ; BIBL., 325.

Saint-Évremond, on opera, 94, 94 n.; BIBL., 326.

St. Patrick's Day, or The Scheming Lieutenant (Sheridan), 299.

St. Serfe, Sir Thomas, his Tarugo's Wiles, 45-46, $46 \mathrm{n}$.

Saintsbury, George, Scott-Saintsbury edition of Dryden's Works cited, $46 \mathrm{n}$. and passim; BIBL., 323; his Dryden cited, 62 n., 67, 67 n.; BIBL., 323 ; his edition of Shadwell, BIBL., 325 .

Samson Agonistes, its non-dramatic character, $92 \mathrm{n}$.

Scarron, Paul,

D'Avenant's borrowing from, 33 . Scenery,

Elizabethan and Restoration use of, compared, 3; D'Avenant's use of, 21, 22, 25-29; rapid development of, on Restoration stage, 40-42,
$58 \mathrm{n} ., 113 \mathrm{n}$.; its increasing importance, 116-117, 168-160; its use in pantomime and spectacle, $187-188,246$.

Schelling, F. E. his chapter in Camb. $B$ ist., BIBL., 317, 323.

School for Guardians, The (Murphy), 256.

School for Scandal, The (Sheridan), 302-307, 124 n., 279, 282, 310, 313 ; compared with Wycherley's Country Wife, 80; Charles Surface in, 125,280 ; Rowley in, 157 n.; its relation to Foote's Minor, 251252 ; Colman's Epilogue to, 262; Joseph Surface in, 271; 'Animadversions' on, 275; BIBL., 339-340.

School for Wives, A (Kelly), 272.

Scott, Sir Walter,

his comment on Spanish and Restoration comedy, 46; on Dryden's All for Love, 92 ; on his Don Sebastian, 93; Scott-Saintsbury edition of Dryden's Works cited, $46 \mathrm{n}$. and passim; BIBL., 323.

Scudéry, Georges de,

his influence on Settle's Ibrahim, 113.

Scudéry, Madeleine de, general influence on Restoration drama, 57, I09; on Dryden's Conquest of Granade, 62; on Settle's Ibrahim, I13; on Banks's Cyrus, 118.

Secret Love, or The Maiden Queen (Dryden), 56 ;

its Prologue cited, 63,63 n., 84, $84 \mathrm{n}$.

Sedley, Sir Charles, dramatic work, III, 78, 110; BIBL., 327.

Semiramis, Ayscough's adaptation of Voltaire's Simiramis, 236.

Sentimental drama, Otway and Southerne as forerunners of, $119,155,160,264,265$; Steele as reputed founder of sentimental comedy, 155; Steele's 
Sentimental drama - Cont. dramas in relation to, $155-165$; sentimental strains in tragedy, I66I67, 184; in Rowe's Fair Penitent, 173-175; Gay's satire on, 192193. 194; sentimental strains in Lillo's George Barnwell, 204, 209; in other tragedies, 209-210; rise and full development of, 264-276 ; Goldsmith and the reaction against, 277-284, 290; Sheridan in relation to, 29I, 294-297, 306-310; BIBL., 336-337.

Settle, Elkanah, dramatic work, I13 ; his translation of Pastor Fido, I08 n.; his debt to French romances, Io9; BIBL., 327 .

Shadwell, Thomas,

dramatic work, 84-86, I04, I05; other references to his version of The Tempest, 4I, 44, 56 n., II 7 , I 70; to his Psyche, 4I, II 7, I70; his Royal Shepherdess, ro8; his opinion of Sedley's Antony and Cleopatra, III, III n.; BIBL., 325.

Shakespeare, William,

(see also separate plays)

contrasted with Restoration dramatists, 4; Restoration attitude towards, 5-6; 'drolls' based on plays of, I6, I8; D'Avenant's connection with, 20-21, 32; Restoration production of plays of, $35-36,43,48$; effect of meagre scenery on, 42; Dryden's attitude towards, 68, 93, 95; Shadwell's comment on, 85; Rymer's attitude towards, 89; Dryden's All for Love in relation to, 88, 90-92; influences Otway, 100, IOI, IOI n.; Restoration adaptations of, 95, 115; Queen Anne performances of, 173, I 83; Rowe's critical edition of, 177,215 ; Rowe's 'imitation' of, 177-178, 184; Addison's opinion of, 180 ; Voltaire's attitude towards, 198-199, 200-201, 236-237; Garrick's acting of, 227-229; earlier versions, editions, and productions of, 230-232; Garrick's versions and productions of, 233-234; Home as the 'Scotch Shakespeare,' 240, 24I ; Colman's productions of, 262; Sheridan in relation to, 313 ; BIBL., 335 .

Sheridan, Mrs. Frances, dramatic work, 260, 292; Rae's edition of her Journey to Bath, BIBL., 339 .

Sheridan, Richard Brinsley, dramatic work, 29I-313; other references to The Critic, 66, 216 , 219, 219 n., 242, 242 n., 270, 272, 279; to The School for Scandal, 80, I 24 n., I 25, I 57 n., 25I, 262, 27 I, $275,279,280,282$; to The Rivals, I62, 258, 273, 273 n., 279, 282; to A Trip to Scarborough, I35; to The Duenna, 194; variously compared with Congreve, I 24, I 24 n., I25, I3I, I32, I4I; his debt to Steele, I62; to Foote, 25I-252; BIBL., 339-340.

Sheridan, Thomas,

father of Richard Brinsley Sheridan, 24I, 253, 29I-292.

She Stoops to Conquer (Goldsmith), 282-290;

compared in plot or characters with earlier dramas, 76, I 26, I 30, I35, I39, I 40, I62 ; Colman's production of, 262, $262 \mathrm{n}$.; compared with Sheridan, 297; BIBL., 337-338.

She Would if She Could (Etherege), 74-75.

Shirley, James, plays of, published during interregnum, 19; anticipation of 'heroic drama,' 22; Restoration performances of, 36; Crowne's Married Beau in relation to, 112; Garrick's alteration of his Gamester, 238.

Short Discourse of the English Stage, $A$, by Richard Flecknoe, cited, 40; BIBL., 322.

Short View of the Immorality, and Profaneness of the English Stage, $A$, Jeremy Collier's essay, 121, 142144.

Short View of Tragedy, $A$, Rymer's essay on, 89, 142. 
Shuter, Edward, actor, 277, 293, 294.

Siddons, Mrs. Sarah, actress, $178,243,256$.

Sidney, Sir Philip, his dramatic theory, 49; his Arcadia, 108.

Siege of Aquileia, The (Home), 240.

Siege of Damascus, The (Hughes), 196-197.

Siege of Rhodes, The (D'Avenant), 2I-27, 32, 33, 43, 44; BIBL., 322.

Silent Woman, The (Jonson), revivals of, 38,183 ;

Colman's version of, 262 .

Silvia (Lillo), 202.

Sir Courtly Nice (Crowne), I12-113 ; Spanish influence on, 46 n., 109 ; its Dedication cited, $72 \mathrm{n}$.

Sir Fopling Flutter (main title, The Man of Mode, Etherege), 75-76, 78 n., 123 ;

other references to the character, Sir Fopling Flutter, I 12, 134, 150.

Sir Francis Drake, The Hislory of (D'Avenant), 27, $27 \mathrm{n}$.

Sir Harry Wildair (Farquhar), 137.

Sir Martin Mar-All (Dryden), 56.

Smith, Edmund, his Phadra and Hippolytus, 179.

Smollett, Tobias George, novels of, 225-226.

Soldier's Forlune, The (Otway), 100.

Solomon's Wisdom, King, a 'droll,' 18.

Sophonisba (Thomson), 197 ; parodied by Fielding, 197, 215.

Sophonisba, or Hannibal's Overthrow (Lee), 96.

Southerne, Thomas,

dramatic work, Ir8-II9; as sponsor for Congreve, 122, 122 n. ; as a forerunner of sentimental drama, 155, 160, 264. 265; other references to, 106 n., 173, $174,202,229,238$.

Spanish Friar, The (Dryden), 93.

Spanish literature,

(especially Spanish drama)

its general influence on early Restoration drama, 45-47; on later Restoration drama, 109 .
Spartan Dame, The (Southerne), 118

Spence, Joseph, his Anecdoles cited, 76 n., 77, 77 n., 89 n., $191 \mathrm{n}$.

Spendthrift, The (Draper), 2 10.

Spouter, The (Murphy ?), 255.

Sprat, Dr. Thomas, assists in The Rehearsal, 64.

Squire of Alsatio, The (Shadwell), 86.

Stapylton, Sir Robert, dramatic work, I16, 116 n.; burlesqued in The Rehearsal, 65.

State of Innocence and Fall of $\boldsymbol{M a n}$, The (Dryden), 67 ;

its 'Apology' cited, 82.

Steele, Sir Richard, dramatic work, I54-165; other references to his $F_{\text {uneral, }}$ I 51 ; to his Lying Lover, 15 I, 174, 192; to his Conscious Lovers, 195, 210, 248; Spanish influence on, 46 ; his sentimental drama anticipated, II9, 264, 265; his verses to Congreve, 129 ; the moral tone of his dramas, 147, 204; his protest against Italian opera, 171 ; BIBL., 330.

Sterne, Laurence, novels of, $355,226$.

Stranger, The, partly adapted by Sheridan, 302. Sullen Lovers, The (Shadwell), 84. Summer's Tale, The (Cumberland), 272.

Surr, T. S., his novel Barnwell, 207.

Suspicious Husband, The (Benjamin Hoadley), 245.

Swift, Jonathan,

his opinion of Vanbrugh's architecture, 133; of Hughes, 196; his connection with Gay's Besgar's Opera, 190-191; his Gullioer's Travels, 194, 225.

Taine, H. A., his History of English Liberature cited, $10 \mathrm{r}-102,102 \mathrm{n}$.

Tamburlaine (Marlowe), its 'heroic' elements, 22, 62. Tomerlane (Rowe), 173, 246. 
Taming of the Shrew, The, Garrick's alteration of, 233.

Tancred and Sigismunda (Thomson), I97;

its Prologue cited, $197 \mathrm{n}$.

Tarugo's Wiles (St. Serfe), 46, $46 \mathrm{n}$. Tasso, Elizabethan versions of his Aminta, 107; Restoration versions of, 108, I08 n.; Dennis's borrowings from (his Gerusalemme Liberata), I67.

Taste (Foote), 253.

Tate, Nahum, dramatic work, 115, 5 .

Tatham, John, dramatic work, 36; his influence on Mrs. Behn, II4; BIBL., 322.

Tavern Bilkers, The (Weaver), pantomimic entertainment, 186.

Tempest, The,

D'Avenant and Dryden's version of, 5, 32, 56, 56 n., 85 n.; Shadwell's version of (music by Locke), 4I, 44, 56 n., 85, 85 n., II 7, I70; Garrick's production of, 234, 248.

Temple Beau, The (Fielding), 214.

Tender Husband, The (Steele), I6I163;

its Epilogue cited, I7I.

Terence, Sedley's debt to his Eunuchus, III; his relation to Southerne, I18; Colman's debt to his Adelphi, 259.

Thackeray, William Makepeace, compared with Fielding, 223; with Townley, 255.

Theatre Royal, The,

later known as Drury Lane, 3I; stock plays at $35-36,38$. (For further references see Drury Lane Theatre.)

Theodosius (Lee), 98;

its Epistle Dedicatory cited, 99, $99 \mathrm{n}$.

Thomas and Sally (Bickerstaff), 257.

Thomson, James,

dramatic work, 197-198; BIBL., 332.

Thorndike, Ashley $\mathrm{H}$., his Tragedy, BIBL., 317-318.
Thracian Wonder, The (pr. I66r. Webster and Rowley?), 107, ro8. Three Hours after Marriage (Gay, Pope, and Arbuthnot), 190.

Thurmond, John, his pantomime, 188.

Timon of Athens,

Shadwell's alteration of, $85,85 \mathrm{n}$.

Titus and Berenice (Otway), roo.

Titus Andronicus,

Ravenscroft's alteration of, III.

Tom Thumb (Fielding), 215-216, 194, 196, 197, 217, 219, 256; BIBL., 333 .

Tovey, D. C., his edition of Gray's Letters cited, $24 \mathrm{In}$.

Townley, James, dramatic work, 254-255, $217,217 \mathrm{n}$. Tragedies of The last Age, The, Rymer's essay on, 88-89.

Tragedy of Tragedies, The (see Tom Thumb), Fielding's expansion of Tom Thumb, 215-216.

Trip to Calais, $A$ (Foote), 25 I.

Trip to Scarborough, A (Sheridan), 301-302, 135 .

Triumph of Love, The, an opera with Italian music, 172.

Triumphant Widow, The (Duke of Newcastle), 84.

Troilus and Cressida, Dryden's alteration of, 93; Dryden's Prologue to, cited, 5, 5 n.; Dryden's essay prefixed to, 93 .

Trotter, Mrs., dramatic work, 167 .

True Widow, $A$ (Shadwell), 86; its Epistle Dedicatory cited, III, III $\mathrm{n}$.

Tuke, Sir Samuel, his Adventures of Five Hours, 6, 45, 109.

Tumble-down Dick, or Phaeton in the Suds (Fielding), 220.

Tunbridge-Wells (Thomas Baker), its Prologue cited, 116.

Tutor, The (Townley), 254.

Twelf th Night,

Wycherley's debt to, 82; revival of, 232. 
Twin-Rivals, The (Farquhar), 137;| Walker, William, its Preface cited, 148.

Two Noble Kinsmen, The (Fletcher and Shakespeare?),

D'Avenant's alteration of, 32 .

Tyrannic Love (Dryden), 60-62.

Ulysses (Rowe), 176.

Unfortunate Lovers, The (D'Avenant), revival of, 32 .

Unhappy Favourile, The (Banks), $117,240$.

Universal Gallant, The (Fielding), 218.

Upholsterer, The (Murphy), 255.

Vanbrugh, Sir John, dramatic work, 132-136, 1 22, 150 ; Sheridan's adaptation of his Relapse, 301-302; his relation to the Collier contruversy, I 23 n., I43, 144-145, 145 n.; Cibber's reference to The Relapse, I49; as manager, 172; BIBL., 328.

Venice Preserved (Otway), ror-ro3, 92, 95 ;

burlesqued by Gay, 190; Garrick acts in, 229 ; BIBL., 326.

Vertue Betray'd (Banks), II7.

Viclorious Love (Walker), I66.

Villiers, George (Duke of Buckingham),

The Rehearsal, 64-66, 55, 55 n., $86,89,213,214,229,229$ n.; its influence on Sheridan, 292, 308, 311; BIBL., 324.

Virginia (Crisp), 239, 240.

Virgin Widow, The (Quarles), its early use of rhyme, 54-55; parodied in The Rehearsal, 55, 55 n., 65.

Virtuoso, The (Shadwell), 84.

Volpone (Jonson), revivals of, 38,183 .

Voltaire,

his general relation to English drama and dramatic criticism, 198-201,235-237 ; compares Wycherley with Molière, 81, 81 n.; his opinion of Cato, 182; his Nanine, 264; its Preface cited, 264 n.; BIBL., 332.

his Victorious Love, 166.

Walpole, Horace,

his Memoirs of George II cited, $221 \mathrm{n}$.; his opinion of She Sloops to Conquer, 289-290; of The School for Scandal, 302-303.

Walpole, Sir Robert, satirized in Gay's Beggar's Opera, I9I-192; in Fielding's farces, 219, 220, 221 ; his connection with the Licensing Act, $22 \mathrm{r}$.

Ward, Sir Adolphus W.,

his History of English Dramatic Literature, cited, 51 n., 57 n., 59 n., 78 n., I I 2, I I 2 n., I 16 n., I30 n., 134, 134 n., 147, 147 n., 150 n., 157 n., 159 n., 172 n.; BIBL., 317 ; his edition of Lillo cited, 203 n., 207 n., 208, 208 n.; BIBL., 332333.

Watkins, John,

his Memoirs of Sheridan cited, 310 , $310 \mathrm{n}$.

Way of the World, The (Congreve), 129-131, 148, 150;

Garrick acts in, 229.

Way to Keep Him, The (Murphy), 255.

Weaver, John,

his connection with pantomime, 184-186; BIBL., 331.

Webster, John,

The Thracian Wonder ascribed to, 107, 108; Tate's adaptation from (his While Devil), II5.

Wedding-Day, The (Fielding), 222 ; its Prologue cited, 230.

Welsted, Leonard,

his Prologue to Steele's Conscions Lovers, 163.

Welwood, James,

his Preface to Rowe's translation of Lucan cited, $173 \mathrm{n}$.

West Indian, The (Cumberland), 273-274, 282.

Westminster Drolleries, a collection of non-dramatic pieces, 17.

What-d'ye-call-it (Gay), 190, 194, 213. 
Wheatley, Henry B., his edition of Pepys's Diary cited, 6 n. and passim; BIBL., 320; his bibliography of Dryden, BIBL., 323.

Wheel of Fortune, The (Cumberland), 274.

Whitehead, William, dramatic work, 239.

Whitelocke, Sir Bulstrode, his connection with D'Avenant's 'opera', 2I, 2 I n.

Wild Gallant, The (Dryden), 54.

Wilkinson, Tate, actor, 252.

Wilson, John, dramatic work, 38-40 ; other references to Jonson's influence on, 43, 72, 83; BIBL., 322.

Winter's Tale, The,

Garrick's alteration of, in Florizel and Perdita, 233.

Wits, The, or, Sport upon Sport, Kirkman's collection of 'drolls,' 16-19; BIBL., 32 .

Wives Excuse, The (Southerne), I 8 , I $18 \mathrm{n}$.

Woffington, Margaret (Peg), her connection with Garrick, 228; acts in Douglas, 240; caricatured by Foote, 249.

Wonder, The (Mrs. Centlivre), I54.

Woodward, Henry, actor, 234, 277.

Word to the Wise, $A$ (Kelly), 272.

Wright, C. H. C., his History of French Literature cited, 44 n.; BIBL., 323.
Wright, James,

his Historia Histrionica cited, 15, I9 n.; BIBL., 319; his Country Conversations anticipates Jeremy Collier, I4I-I42.

Wycherley, William, dramatic work, 77-83, 86, I04, 105, I06, I40; Spanish influence on, 46, rog; incidentally compared with Congreve, I23, I24, I24 n., 126, 127, 132; with Vanbrugh, I32, I35; with Farquhar, I38; with Cibber, I52 ; with Colman, 260 ; with Sheridan, 306 ; defended by Dennis, 145; Bickerstaff's debt to, 257; Sheridan's alleged debt to, in The Duenna, 300 ; BIBL., 324-325.

Ximena (alternative title to The Heroic Daughter, Cibber), 183.

Yale University Dramatic Association, its revival of Goldsmith's Good Natur'd Man, $279 \mathrm{n}$.

Yates, Mrs., actress, I78.

York's, Duke of, company of actors, $3 \mathbf{I}$.

Young, Edward, dramatic work, I95-196; BIBL., 332.

Zara (Hill), 200, 201.

Zenobia (Murphy), 256.

Zobeide,

Cradock's adaptation of Vol. taire's Les Scythes, 236. 



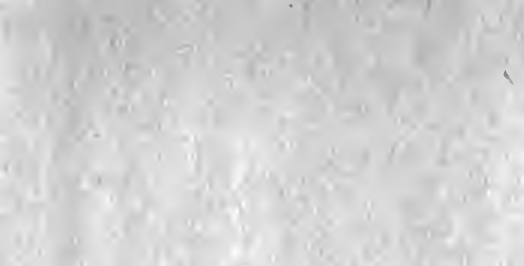

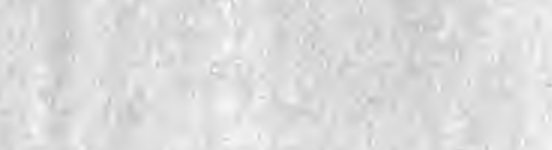

1)

Q $+1+1+2+1+2$

.

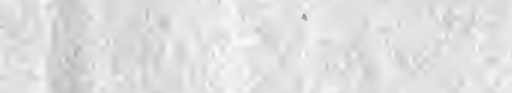

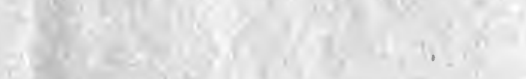

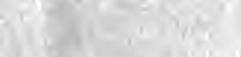

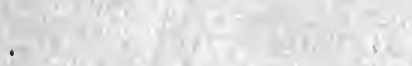

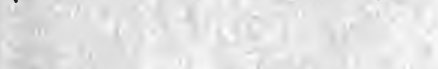

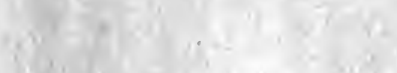

$(1+1,5$

$7 x^{2}+1,5$

$\sqrt{1}$

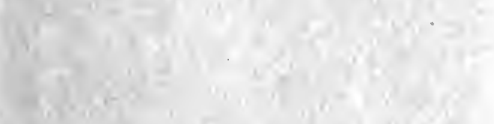

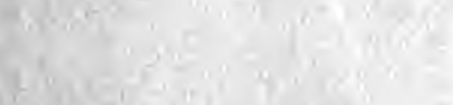

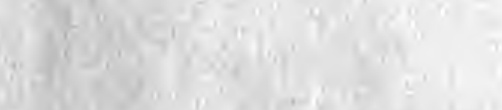

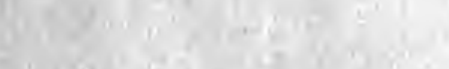

4.

(2) 3

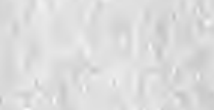

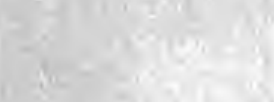

(1)

t. 



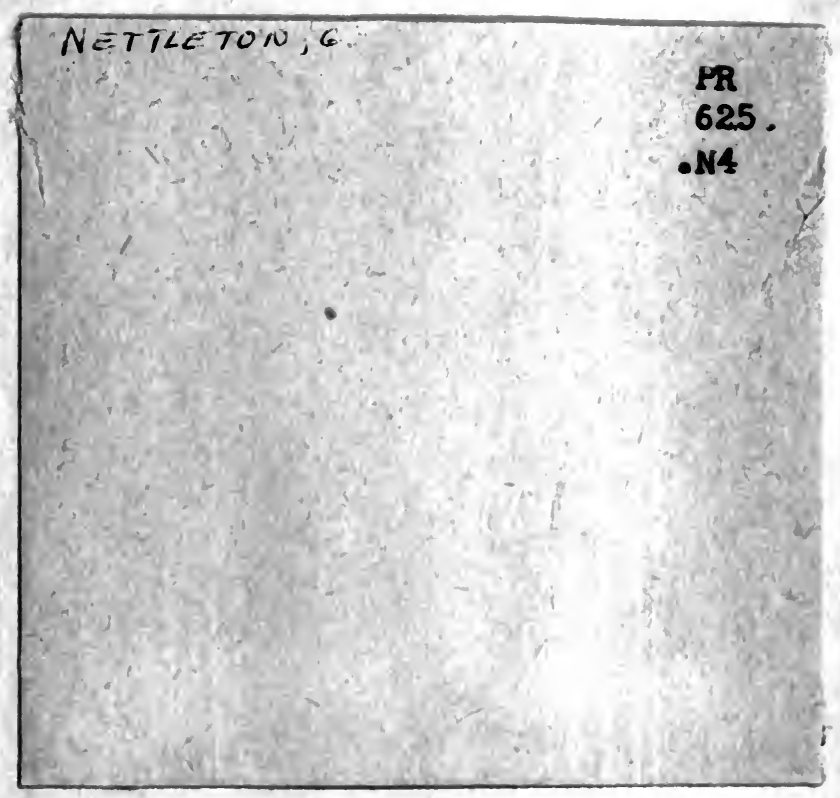




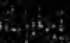
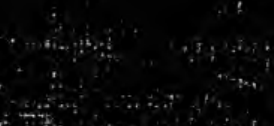

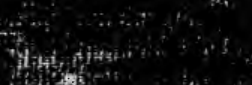

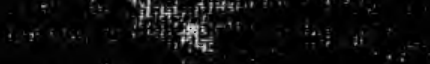

n:

in:

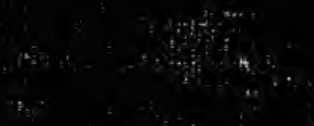

4

$=\frac{3}{4}+\frac{5}{4}+4$

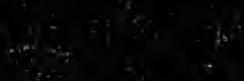

$-4$

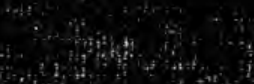

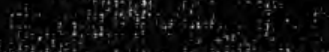

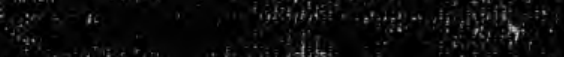

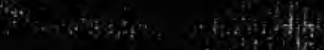

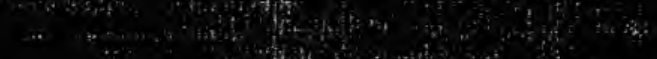

\section{$\cdots$}
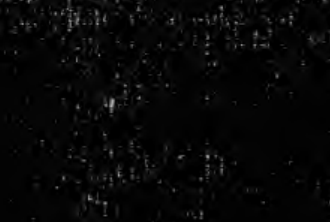

....... 